UNIVERSIDADE DE BRASÍLIA - UNB INSTITUTO DE CIÊNCIAS HUMANAS

DEPARTAMENTO DE GEOGRAFIA

PROGRAMA DE PÓS-GRADUAÇÃO EM GEOGRAFIA

ÁREA DE CONCENTRAÇÃO: GESTÃO AMBIENTAL E TERRITORIAL

LINHAS DE PESQUISA: ANÁLISE DE SISTEMAS NATURAIS

\title{
ANÁLISE CLIMATOLÓGICA DO MUNICÍPIO DE CAICÓ/RN: SUBSÍDIOS À AVALIAÇÃO DO CONFORTO HUMANO
}

Discente: Msc. Rebecca Luna Lucena

Orientadora: Dra. Ercília Torres Steinke

Brasília, novembro de 2016. 
UNIVERSIDADE DE BRASÍLIA - UNB

INSTITUTO DE CIÊNCIAS HUMANAS

DEPARTAMENTO DE GEOGRAFIA

PROGRAMA DE PÓS-GRADUAÇÃO EM GEOGRAFIA

ÁREA DE CONCENTRAÇÃO: GESTÃO AMBIENTAL E TERRITORIAL

LINHAS DE PESQUISA: ANÁLISE DE SISTEMAS NATURAIS

\section{ANÁLISE CLIMATOLÓGICA DO MUNICÍPIO DE CAICÓ/RN: SUBSÍDIOS À} AVALIAÇÃO DO CONFORTO HUMANO

Discente: Msc. Rebecca Luna Lucena

Orientadora: Dra. Ercília Torres Steinke

Tese de Doutorado apresentada ao programa de pós-graduação de Geografia da Universidade de Brasília, sob a orientação da Professora Dra. Ercília Torres Steinke.

Brasília, novembro de 2016. 


\section{FICHA CATALOGRÁFICA}

LUCENA, REBECCA LUNA. Análise climatológica do município de Caicó/RN: subsídios à avaliação do conforto humano. 2016. 152 p. (UnB, Geografia, 2016). Tese de Doutorado - Universidade de Brasília. Instituto de Humanidades. Departamento de Geografia. 1. Climatologia 2. Semiárido 3. Precipitações 4. Conforto térmico I. GEO/IH/UnB

\section{REFERÊNCIA BIBLIOGRÁFICA}

LUCENA, R. L. Análise climatológica do município de Caicó/RN: subsídios à avaliação do conforto humano. (TESE) Departamento de Geografia, Universidade de Brasília, Brasília, DF, 2016. $152 \mathrm{p}$. 
REBECCA LUNA LUCENA

\section{ANÁLISE CLIMATOLÓGICA DO MUNICÍPIO DE CAICÓ/RN: SUBSÍDIOS À AVALIAÇÃO DO CONFORTO HUMANO}

Tese aprovada como requisito parcial à obtenção do grau de Doutor no Curso de PósGraduação em Geografia, Instituto de Humanidades, da Universidade de Brasília, pela seguinte banca examinadora:

Orientador:

Profa Dra. Ercília Torres Steinke Dept ${ }^{\circ}$ de Geografia, UnB

Membro externo:

Prof. Dr. Rômulo da Silveira Paz - Presidente da Sociedade Brasileira de Meteorologia (SBMET)

Membro interno:

Profa Dra. Helen da Costa Gurgel Dept ${ }^{0}$ de Geografia, UnB

Membro interno:

Profa Dra. Roselir de Oliveira Nascimento Dept ${ }^{\circ}$ de Geografia, UnB

Membro externo:

Profa Dra. Selma Regina Maggiotto, Faculdade de Agronomia e Medicina Veterinária, UnB

Brasília, 28 de Novembro de 2016. 


\section{AGRADECIMENTOS}

Agradeço a minha mãe Maria Salomé de Luna, meu pai Milton Lucena e meus irmãos Laura Luna e Eudo Augusto de Luna, o meu alicerce sempre... Aos meus cunhados Rogério e Erika, meu sobrinho amado Uirá Luna e a todos os meus familiares, pessoas importantíssimas, que amo muito.

Aos meus amigos/irmãos Sarah Luna e Aluizzio Vieira, vocês são as colunas do alicerce!

Agradeço imensamente a todos os meus amigos de João Pessoa, de Caicó, de Londres e Brasília, pessoas que amo e respeito, seres humanos especiais, como:

Sócrates Lopes, Maribel Olaya, Jório Cabral, Tainá Myra, Ana Luiza Sis, Manaíra, Keroline, Karlinha, Dermeson, Michelle Nogueira, Jan Medeiros, Silinha, Aline, Marluce, Leila, Alany, Oozan, Janaína, Anicleide, Larissa, Aroldo, Gedson, Lucas, Magda Guilhermino, Almir Miranda, Leonor Pacheco, Christina Pacheco, Raphael Pacheco, Natalia Polari e Izabella Tucci e tantos outros amigos queridos que não estão aqui, mas que sabem o quanto são importantes pra mim...

Agradeço infinitamente a minha amiga Erica Ferrer que muito me ajudou durante e na reta final desse doutorado, obrigada Ferrer!

Um agradecimento especial para Seu Joao, meu ajudante e amigo que me amparou tanto nesse tempo do doutorado, inclusive na instalação dos abrigos para os termohigrômetros

À minha aluna Priscilla que também me ajudou, com toda sua dedicação e eficácia, na instalação dos equipamentos

À minha professora Dra. Ercília Torres Steinke, uma pessoa linda, sempre muito atenciosa e otimista com relação ao meu trabalho, obrigada profa!

A todos os professores da pós-graduação em Geografia da UnB que me ensinaram muito. Em especial aos profs. Valdir Steinke e Mário Diniz 
Aos professores doutores que fizeram parte da banca de defesa sou grata pelas excelentes contribuições ao trabalho. Pessoas inteligentes e profissionais: Rômulo Paz, Helen Gurgel, Roselir Nascimento e Selma Maggiotto

A todos os meus colegas de curso da UnB e aos colegas de trabalho da UFRN

Ao meu chefe de departamento Diego Salomão Salvador, por todo apoio a mim prestado

Ao Instituto Nacional de Meteorologia (INMET) por conceder os dados meteorológicos utilizados nessa pesquisa nessa pesquisa

À Universidade de Brasília (UnB) por disponibilizar os equipamentos termohigrômetros fundamentais para o desenvolvimento mais apurado deste trabalho

À Fundação de Apoio à Pesquisa do Distrito Federal (FAPDF) pelo auxilio financeiro dado quando da participação em evento no exterior para apresentação de resultados preliminares da tese

Aos moradores da cidade de Caicó/RN que permitiram a instalação dos termohigrômetros em suas calçadas e que cuidaram dos equipamentos com muita dedicação sem ter qualquer responsabilidade sobre os mesmos, assim como a população caicoense que sempre prezou pelos equipamentos.

Aos governos Lula/Dilma, pelos projetos realizados visando a melhoria do ensino superior no Brasil, assim como a interiorização da educação, contribuindo muito para a mudança da realidade sertaneja. Obrigada Luiz Inácio Lula da Silva e Dilma Vana Rousseff!

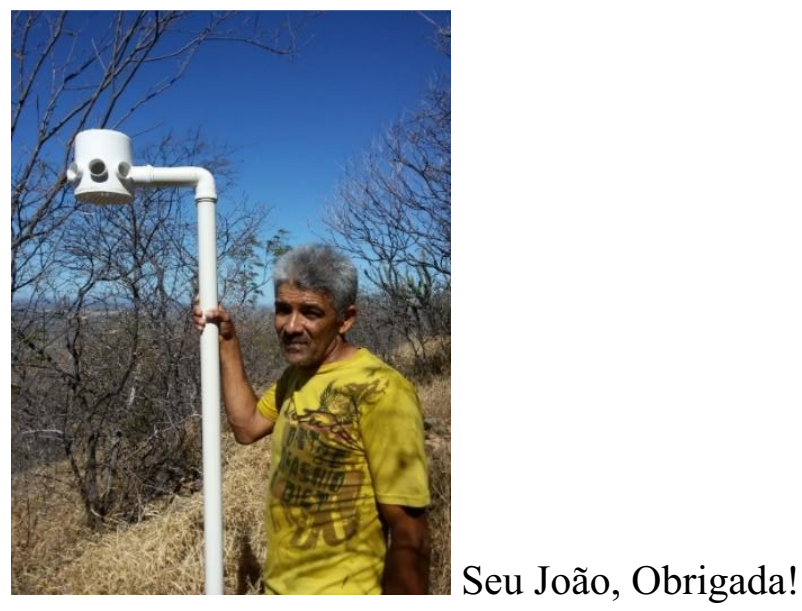


"Certo dia, enquanto vagava pelas montanhas, procurei me abrigar de uma tempestade que se aproximava. O céu cobriu-se de nuvens espessas, pesadas, mas por alguma razão não começava a chover ate que, de repente, um relâmpago cortou o ar e, pouco tempo depois caiu um aguaceiro. Aquela observação deume o que pensar. Era claro que os dois fenômenos estavam intimamente relacionados, como causa e efeito, e uma breve reflexão levou-me à conclusão de que a energia elétrica envolvida na precipitação de água era insignificante, e que a função do relâmpago era como a de um gatilho sensível. Havia ali uma estupenda possibilidade de realizar alguma coisa. Se produzíssemos efeitos elétricos com a qualidade necessária, poderíamos transformar o planeta inteiro e as condições de vida sobre ele. O Sol ergue a agua dos oceanos e os ventos a levam a regiões distantes, onde ela permanece num estado de equilíbrio delicadíssimo. Se pudéssemos perturbar esse equilíbrio onde e quando quiséssemos, essa poderosa corrente de vida poderia ser controlada voluntariamente. Poderíamos irrigar desertos áridos, criar lagos e rios e oferecer potencia motriz em quantidades ilimitadas. Essa seria a maneira mais eficiente de aproveitar a energia solar para o benefício da humanidade. A implicação desse plano dependeria apenas da nossa capacidade de desenvolver forças elétricas da mesma amplitude das que ocorrem na natureza.

Parecia uma façanha impossível, mas decidi tentar, e imediatamente, ao voltar aos Estados Unidos no verão de 1892, depois de breve visita aos amigos em Watford, na Inglaterra, iniciei o trabalho, pra mim ainda mais atraente, pois um recurso do mesmo tipo era necessário para o sucesso da transmissão de energia sem fio. Empreendi na época mais um estudo atento da Bíblia, e descobri a chave do Apocalipse.” Nikola Tesla (1856-1943)

TESLA, N. Minhas invensões: a autobiografia de Nikola Tesla, São Paulo: Editora Unesp, 2012. 


\section{MINHA INSINUAÇÃO NA PESQUISA}

“(...) pego mais um ovo na cozinha, quebro-lhe a casca e forma. E a partir deste instante exato nunca existiu um ovo. É absolutamente indispensável que eu seja uma ocupada e uma distraída...

(...) Amor é quando é concedido participar um pouco mais. Poucos querem o amor, porque o amor é a grande desilusão de tudo o mais. E poucos suportam perder todas as outras ilusões. Há os que voluntariam para o amor, pensando que o amor enriquecerá a vida pessoal. É o contrário: amor é finalmente a pobreza. Amor é não ter. Inclusive amor é a desilusão do que se pensava que era amor. E não é prêmio, por isso não envaidece, amor não é prêmio, é uma condição concedida exclusivamente para aqueles que, sem ele, corromperiam o ovo com a dor pessoal...

(...) Mas e o ovo? Este é um dos subterfúgios deles: enquanto eu falava sobre o ovo, eu tinha esquecido do ovo. "Falai, falai", instruíram-me eles. E o ovo fica inteiramente protegido por tantas palavras. Falai muito, é uma das instruções, estou tão cansada. Por devoção ao ovo, eu o esqueci. Meu necessário esquecimento. Meu interesseiro esquecimento. Pois o ovo é um esquivo. Diante de minha adoração possessiva ele poderia retrair-se e nunca mais voltar. Mas se ele for esquecido. Se eu fizer o sacrifício de esquecê-lo. Se o ovo for impossível. Então - livre, delicado, sem mensagem alguma para mim - talvez uma vez ainda ele se locomova do espaço até esta janela que desde sempre deixei aberta. E de madrugada baixe no nosso edifício. Sereno até a cozinha. Iluminando-a de minha palidez...” Clarice Lispector (1920 - 1977)

O Ovo e a galinha 


\section{RESUMO}

O semiárido brasileiro, um dos mais povoados do mundo, abriga uma população de aproximadamente 23 milhões de habitantes distribuída em 1135 municípios, estando 62\% desta população em área urbana e $38 \%$ na zona rural. Partindo do pressuposto de que o clima semiárido impõe naturalmente limitações hídricas que podem gerar problemas ao crescimento dos municípios e partindo do pressuposto de que o processo de urbanização pode promover mudanças no campo térmico, gerando aumento de temperatura, o objetivo principal dessa pesquisa foi analisar as condições hidroclimatológica e higrotérmica do município de Caicó/RN/Brasil, com a finalidade de gerar subsídios ao planejamento e a gestão municipal, visando ações do governo e da sociedade que, combinadas com os elementos do clima supracitados, estejam ligadas a qualidade de vida da população. Para realização da pesquisa, foi feita uma análise do campo hidroclimatológico tanto para o estado do Rio Grande do Norte (série histórica de 1963-2013) quanto para o município de Caicó, onde dados de precipitação (série histórica de 1911-2013), evaporação e evapotranspiração (série histórica de 1996-2013) serviram de base para análises estatísticas, geoestatísticas e para a aplicação de índices climáticos. No campo higrotérmico, foram utilizados dados de temperatura do ar, umidade relativa do ar e velocidade do vento de Caicó, tanto das normais climatológicas provisórias (série histórica de 1996-2010) quanto dados horários provenientes de termo-higrômetros automáticos (período de 05/05/2016-05/06/2016) que foram instalados na cidade durante essa pesquisa. Nesse campo de estudo, foram aplicadas técnicas estatísticas e índices bioclimáticos de conforto humano. Os resultados mostraram a especialidade climática do município de Caicó, seu comportamento e características hidroclimatológicas e higrotérmicas principais e como a ação humana pode interferir na superfície local, no sentido de promover melhorias ou retrocessos quando da interação superfícieatmosfera ao nível local.

Palavras-chave: Clima, Caicó/RN, semiárido, análise hidroclimatológica, análise higrotérmica, precipitação, temperaturas, conforto humano. 


\begin{abstract}
Brazilian semi-arid region, one of the most populated in the world, have a population of approximately 23 million inhabitants distributed in 1135 municipalities, with $62 \%$ in urban areas and $38 \%$ in rural areas. Assuming that the semi-arid climate naturally imposes water restrictions that can generate problems for the growth of the municipalities and assuming that the urbanization process can promote changes in the thermal field, generating temperature increase, the main goal of this research was to evaluate the hydroclimate and hygrothermal conditions of the city of Caicó/RN/Brazil, in order to offer a backup for municipal management and for society actions, which combined with the climate elements, are closely related to the population's quality of life. Hydroclimatological analysis were performed on the state of Rio Grande do Norte (historical data 1963-2013) and on the city of Caicó, using rainfall (historical data 1911-2013), evaporation and evapotranspiration (historical data 19962013) data for statistical and geostatistical analysis and to apply climatic indices. Air temperature, relative humidity and wind speed data from Caicó (historical data 1996-2010) were collected from both climate normals and automatic thermo-hygrometers (period 05/05/2016-05/06/2016) installed around the city during this study period. For hygrothermal analysis, statistics and bioclimatic levels of human comfort were applied. The results express the climatic peculiarities of this city, its behavior and the main hydroclimate and hygrothermal characteristics showing how human activities can interfere with the local area to either improve or worsen the land-surface atmosphere interaction at a local level.
\end{abstract} Keywords: Climate, Caicó / RN, semi-arid, hydroclimate analysis, hygrothermal analysis, precipitation, temperatures, human comfort 


\section{SUMÁRIO}

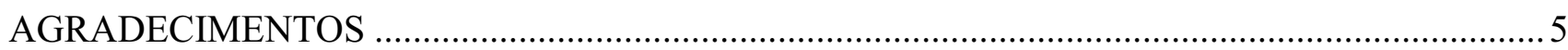

MINHA INSINUAÇÃO NA PESQUISA …...................................................................... 8

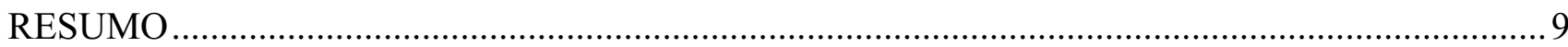

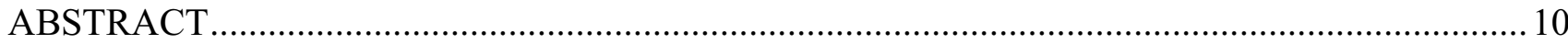

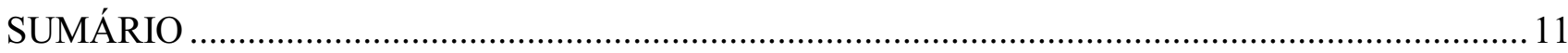

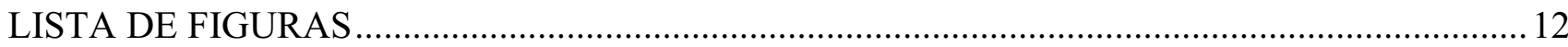

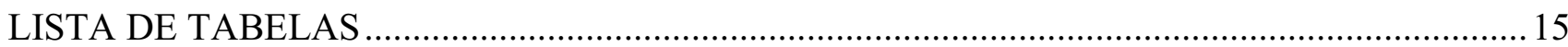

CAPÍTULO 1 A contribuição do estudo climático para o planejamento e a gestão municipal no

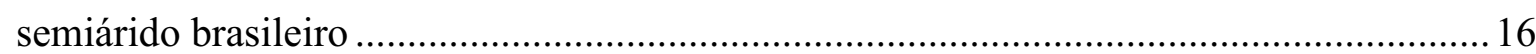

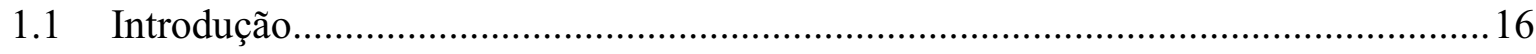

1.2 O objeto de estudo: o município de Caicó/RN ........................................................22

1.3 Objetivos da pesquisa e estrutura do trabalho .........................................................

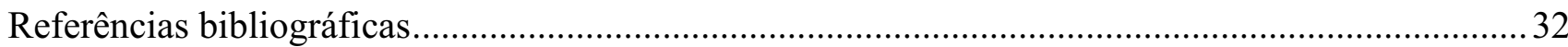

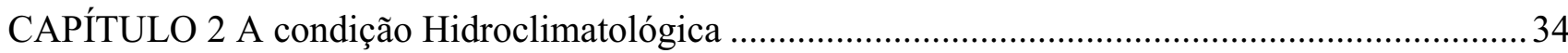

2.1 Artigo 1 Comportamento hidroclimatológico do estado do Rio Grande do Norte e do

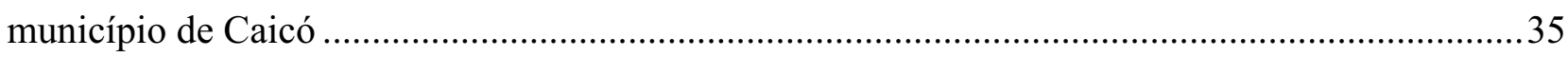

2.2 Artigo 2 Variabilidade climática no município de Caicó/RN: secas e chuvas num arquétipo do clima semiárido do Nordeste brasileiro. ...................................................................54

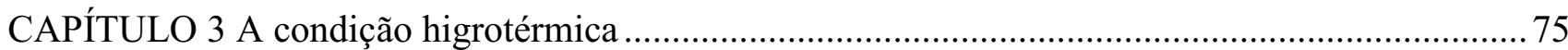

3.1 Artigo 1 Calor e conforto humano em uma cidade da região semiárida do Brasil .........76

3.2 Artigo 2 Análise higrotérmica do município de Caicó/RN/Brasil................................96

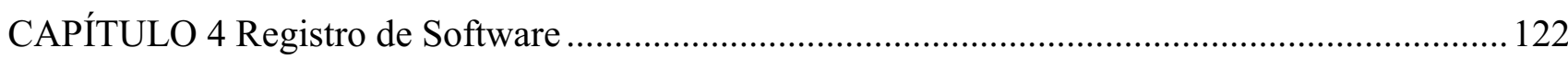

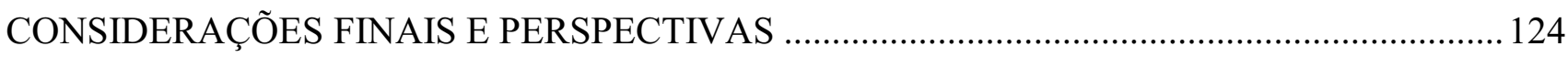

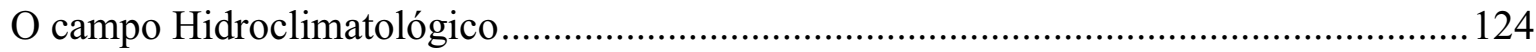

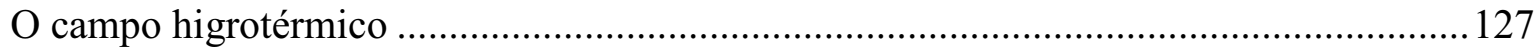

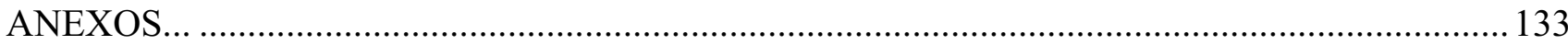

Anexo 1 artigo 1 do capítulo 3 publicado em inglês revista international journal of climate change:

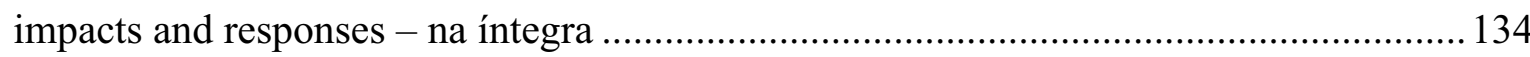




\section{LISTA DE FIGURAS}

\section{Capítulo 1}

Figura 1 Mapa com os dois grandes tipos climáticos predominantes no Nordeste brasileiro na atualidade. .19

Figura 2 Mapa de Localização de Caicó no estado do Rio Grande do Norte e no Brasil, com destaque para o recorte municipal e a área urbanizada, com o açude Itans, na imagem a direita .24

Figura 3 Condições climáticas e meteorológicas atuantes em Caicó/RN, escala sinótica e local ......26 Figura 4 Aspecto da Caatinga no município de Caicó. Em (a) vista da depressão sertaneja desde a serra de São Bernardo. Em (b) aspecto de um afloramento (lajedo) muito comum na Caatinga do Seridó.

Figura 5 Plantas da cidade de Caicó mostrando a evolução histórica da urbanização. Notam-se, nas imagens, os rios Seridó e Barra Nova. .28

Figura 6 Tomada da área urbana do município de Caicó onde se podem ver inúmeras construções às margens dos rios Seridó e Barra Nova. Fonte: Google Earth, 2013. .29

\section{Capítulo 2 - Artigo 1}

Figura 1 Mesorregiões Geográficas do estado do Rio Grande do Norte

Figura 2 Distribuição da chuva em um ano "normal”, baseado na média climatológica (quartis). ...42

Figura 3 Distribuição da chuva em um ano "chuvoso" 2009, (quartis)..........................................43

Figura 4 Distribuição da chuva em um ano "seco" 2013 (quartis).................................................44

Figura 5 Total de chuva anual registrado no Rio Grande do Norte em uma ano chuvoso (2009) mapa azul e em um ano seco (2013) mapa em laranja e o resultado do coeficiente de redistribuição...........45 Figura 6 Histograma de distribuição de totais anuais de precipitação em Caicó (período 1911-2010).46 Figura 7 Gráfico de pizza mostrando a proporção de anos susceptíveis à desertificação no município de Caicó para o período de 2003 à 2013. .50

\section{Capítulo 2 - Artigo 2}

Figura 1 Município de Caicó, na perspectiva do Brasil e a paisagem típica de sua zona rural, situada no domínio da Caatinga do Sertão do Seridó. .56

Figura 2 Imagens do satélite Meteosat (IR), onde se pode observar a banda de nebulosidade produzida pela FIT (ZCIT) em momentos distintos.

Figura 3 (a) meia normal de 1911 a 1930, (b) normal climatológica de 1931 a 1960, (c) normal climatológica de 1961-1990 e (d) normal provisória de 1991 a 2010. Os dados referem-se à quantidade média de chuva precipitada (em milímetros) em Caicó.... .64

Figura 4 Gráfico ombrotérmico de Gaussen elaborado para o período de 15 anos. Os meses em que a linha de precipitação estiver abaixo da linha de temperatura são considerados biologicamente secos, com implicações ao desenvolvimento de vida vegetal. 
Figura 5 Gráfico ombrotérmico de Gaussen para o ano 2009, ano considerado chuvoso - precipitação total $1191.2 \mathrm{~mm}$.

Figura 6 Gráfico ombrotérmico de Gaussen para o ano 1998, ano considerado seco - precipitação total $174.6 \mathrm{~mm}$.

Figura 7 Total anual de chuva em milímetros no município de Caicó - RN de 1911 a 2010, com linha de tendência de previsão e destaque para dois episódios intensos de El Niño e dois de La Niña. .68

\section{Capítulo 3 - Artigo 1}

Figura 1 Mapa de localização do município de Caicó no Brasil, com delimitação do estado do Rio Grande do Norte, do município e a sede municipal (esquerda), Avenida Coronel Martiniano (direita superior) e a Estação Climatológica do Seridó (direita inferior)

Figura 2 Representação gráfica da temperatura máxima, média e mínima do ar no município de Caicó .84

Figura 3 Gráfico de temperatura máxima anual para o município de Caicó-RN (1996-2010) com linha de tendência de previsão para dois períodos

Figura 4 Gráfico de temperatura mínima anual para o município de Caicó-RN (1996-2010) com linha de tendência de previsão para dois períodos...

Figura 5 Sensação térmica média anual para Caicó segundo o índice de Desconforto ID (período 1996 - 2010)

Figura 6 Sensação térmica média anual para Caicó segundo o índice de Temperatura Efetiva - TEv (período 1996 - 2010)

Figura 7 Sensação térmica média anual para Caicó segundo o índice Térmico Climático Universal ITCU (período 1996 - 2010).

Figura 8 (a, b, c, d, e and f) Fachadas de vidro nas construções e podas drásticas realizadas na altura do poste de iluminação pública, ano de 2014 . .90

\section{Capítulo 3 - Artigo 2}

Figura 1 Localização do município de Caicó no Brasil (esquerda), aspecto da paisagem natural com o açude Itans (direita superior) e vista da paisagem urbana localizada na depressão sertaneja com a serra de São Bernardo ao fundo (direita inferior).

Figura 2 Malha urbana de Caicó com os 11 pontos escolhidos para coleta. 101

Figura 3 Termohigrômetros automáticos e os abrigos construídos. 103

Figura 4 Vista parcial da Avenida Coronel Martiniano (ponto 10) ................................................ 108

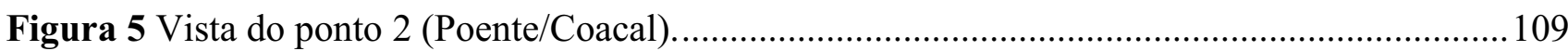

Figura 6 Vista da área rural (ponto 11) pousada Céu Azul. ........................................................... 110

Figura 7 Vista da rua arborizada no centro (ponto 7).

Figura 8 Valores médios diários de ID para diferentes locais no município de Caicó. Destaque para os pontos 2 e 10, que ultrapassam a faixa de "maior desconforto" em alguns dias do mês. 
Figura 9 Valores médios diários de TE para diferentes locais no município de Caicó. Pode-se perceber no gráfico que todos os pontos ultrapassam a linha vermelha indicando "calor moderado". 113

Figura 10 Valores médios diários de ITU para diferentes locais no município de Caicó. Mais uma vez, merecem destaque os pontos 2 e 10, que se apresentam sempre mais elevados (linhas verde e roxa) e o ponto 11 (linha preta) que está sempre na posição mais baixa.

Figura 11 Índice de Desconforto aplicado para a hora mais quente e mais fresca do dia. 115

Figura 12 Índice de Temperatura Efetiva aplicado para a hora mais quente e mais fresca do dia...116 Figura 13 Índice de Temperatura e Umidade aplicado para a hora mais quente e mais fresca do dia.

Figura 14 Imagem da avenida Coronel Martiniano (ponto 10), considerado o mais quente junto ao ponto 2 .

Figura 15 Aspecto sombreado da rua estreita e arborizada localizada no centro da cidade de Caicó (ponto 7)

\section{Capítulo 4}

Figura 1 Interface do software em elaboração "Conforto Climático" "Human Climate Comfort”.....123

\section{Considerações finais e perspectivas}

Figura 1 Os pontos mais quentes (vermelho) e os pontos menos quentes (azul) em Caicó. Os demais pontos que não estão em destaque apresentaram condições termohigramétricas semelhantes entre si. 


\section{LISTA DE TABELAS}

\section{Capítulo 2 - Artigo 1}

Tabela 1 Valores quantitativos e qualitativos para o índice de aridez e susceptibilidade à desertificação.

Tabela 2 Valores médios anuais de medidas de tendência central e de dispersão para o município de Caicó (período de 1996 - 2013). 46

Tabela 3 Tempo de retorno em anos para precipitação e evaporação dispostos em classes. .48 Tabela 4 Índice de Aridez e Susceptibilidade à Desertificação para o município de CaicóRN para os dez últimos anos (período 2003 - 2013).

\section{Capítulo 3 - Artigo 1}

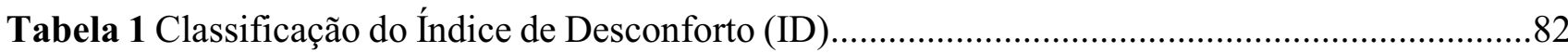

Tabela 2 Classificação do índice de Temperatura Efetiva em função do Vento (TEv) .......................82

Tabela 3 Classificação do Índice Climático Térmico Universal (UTCI). ........................................83

Tabela 4 Média, Desvio Padrão e Coeficiente de Variação das temperaturas máximas e mínimas do ar. Caicó, normal climatológica provisória (1996 - 2010).

Tabela 5 Índices de conforto humano ID, TEv e UTCI aplicados para o município de Caicó série histórica de 1996 - 2010, média anual.

\section{Capítulo 3 - Artigo 2}

Tabela 1 Nome do ponto, coordenadas geográficas, altitude e característica principais 102

Tabela 2 Classificação (nível de conforto humano) segundo valores de ID..................................104

Tabela 3 Sensação térmica sengundo os valores de Temperature Efetiva.....................................105

Tabela 4 Valores e sensação térmica relacionada ao índice de Temperatura e umidade...................105 Tabela 5 Número de registro de temperatura superior a $35^{\circ} \mathrm{C}$ e $40^{\circ} \mathrm{C}$, em cada ponto selecionado 107 Tabela 6 Número de registro de temperatura inferior a $24^{\circ} \mathrm{C}$ e $22^{\circ} \mathrm{C}$, em cada ponto selecionado. .107

\section{Considerações finais e perspectivas}

Tabela 1 Tempo de retorno para quantidade anual de chuva para Caicó, baseado no período de 1911 a 2010

Tabela 2 Anos de forte El Niño e total anual de precipitação em Caicó ..........................................126

Tabela 3 Anos de forte La niña e total anual de precipitação em Caicó 


\section{CAPÍTULO 1 A contribuição do estudo climático para o planejamento e a gestão municipal no semiárido brasileiro}

\subsection{Introdução}

O clima pode ser definido como a sucessão de tipos de tempo ou como o conjunto de variações dos estados médios da atmosfera (podendo ocorrer anomalias), sobre um determinado lugar (TORRES; MACHADO 2011). Ele surge da interação entre a energia solar e a superfície da Terra (massas de água/continentes), se manifestando na camada gasosa que se formou envolta do nosso planeta, a atmosfera, sendo o Sol o combustível fundamental para a dinâmica atmosférica (DIAS; SILVA, 2009). Desse modo, todos os lugares do planeta Terra possuem características climáticas que são peculiares à sua localização (latitude; longitude) somadas às feições superficiais que podem ser naturais (terra/água; altitude; relevo; cobertura vegetal) ou modificadas pela ação humana (agricultura; cidades; complexos industriais). A partir da entrada de energia solar e de sua interação com as feições superficiais dos diferentes lugares, têm-se os diversos tipos climáticos, que incluem em seu conjunto não apenas as condições meteorológicas predominantes como também os eventos esporádicos ou extremos, ambos influenciando diretamente a humanidade e demais formas de vida (OLIVEIRA, 2010). Logo, para que se defina o clima de um determinado lugar, deve-se entender que há o predomínio de condições meteorológicas consideradas "normais", mas que também ocorrem, esporadicamente ou com menor frequência, eventos considerados "excepcionais" ou mesmo "extremos".

Mas qual é a importância de se conhecer o clima de um determinado lugar? Defini-lo, descrevêlo, por si só não oferece muita importância ou utilidade. Entendê-lo, reconhecê-lo, identificar sua relação com a superfície terrestre, conseguir prevê-lo, para assim conviver de modo harmônico com o clima seria a resposta para o fim de muitos problemas que afetam a humanidade e sua sobrevivência na atualidade. Eis a importância do conhecimento climático de qualquer região ou lugar do mundo: aplicá-lo e tê-lo como subsídio para ações dos governos (gestores) e da sociedade (população) voltadas ao bem estar e a melhor qualidade de vida, respeitando os bens naturais que podem ser utilizados, pois o clima está diretamente relacionado a esses elementos da natureza e sua disponibilidade para utilização humana, seja no fornecimento de água através das chuvas, na sazonalidade dos rios e águas subterrâneas, na formação dos solos, na cobertura vegetal e na distribuição dos biomas sobre a Terra, 
assim como nas atividades do dia-a-dia, trabalho e lazer realizadas pelas pessoas (TROPPMAIR, 2004; AYOADE, 2007; TORRES; MACHADO, 2011).

Numa perspectiva sistêmica, o estudo do clima trata dos padrões de comportamento da atmosfera em suas interações com a superfície do planeta e com as atividades humanas realizadas sobre essa superfície (MENDONÇA; DANNI-OLIVEIRA, 2007), sendo fundamental o seu conhecimento para o estabelecimento e a manutenção da qualidade de vida da população, vinculado ao adequado planejamento e gestão dos bens naturais e humanos disponíveis. Foi sob essa ótica de indissociabilidade entre o clima, os elementos naturais e a humanidade, mas reconhecendo que a humanidade depende mais do clima e dos benefícios da natureza do que o oposto, que surgiu-me a idéia de estudar as condições climáticas de um município localizado no domínio climático semiárido do Brasil, dando ênfase a temas importantes da climatologia, que são aqueles ligados à condição "hídrico-climatológica" e "termo-higrométrica", que por sua vez têm influência direta no desenvolvimento social e na qualidade de vida da população.

Para justificar a escolha do campo "hidroclimatológico" dentro da Climatologia, deve-se ressaltar que, no mundo, assim como no Brasil, os desastres naturais mais recorrentes estão relacionados à falta de água e ao excesso dela. Em outras palavras, segundo o levantamento dos desastres naturais brasileiros publicado no "Atlas Brasileiro de Desastres Naturais” (CEPED/UFSC, 2012), as secas e estiagens são o tipo de desastre mais recorrente no país, responsável por 54\% do total de desastres registrados, seguido pelas inundações bruscas e alagamentos, estas últimas responsáveis por $21 \%$ de todos os desastres naturais registrados no país. Ainda, segundo dados do Atlas Brasileiro de Desastres Naturais, a região brasileira mais afetada por desastres naturais é a região Nordeste, que apresenta-se tanto vulnerável aos eventos de seca quanto aos eventos de inundação brusca e gradual, segundo e terceiro fatores de desastres nesta região do Brasil. Tais fenômenos causam danos a população, geram impactos significativos sobre a dinâmica econômica e social, sendo por esse motivo caracterizados como "desastres" (CEPED/UFSC, 2012). Entretanto, sabe-se que a ocorrência e a persistência dos desastres estão diretamente relacionadas a problemas de organização territorial e vulnerabilidade social, que se somam às condições climáticas predominantes e as episódicas.

Com relação a escolha do campo "higrotérmico" dentro do universo climático, esta se justifica pela importância de se obter informações sobre o "conforto térmico humano" ao qual as populações estão vulneráveis em regiões naturalmente quentes, como no semiárido brasileiro, e submetidas ao processo de urbanização. Nos estudos do clima urbano realizados no Brasil, muito se tem trabalhado 
com as "ilhas de calor", sua identificação, causas e consequências (ZAVATTINI, 2004), mas poucos estudos brasileiros trazem a relação entre as ilhas de calor e o conforto térmico humano por meio da aplicação de índices bioclimáticos de conforto humano. Se pensarmos na região semiárida brasileira, os estudos de clima urbano e conforto térmico são ainda mais escassos, visto que boa parte das pesquisas em clima urbano, ilhas de calor e conforto térmico foram desenvolvidos na região sudeste do país e nas capitais brasileiras. Também, o fato de que no semiárido, as pesquisas historicamente têm destacado a questão hídrica, priorizando o campo das precipitações na climatologia, pode justificar os modestos trabalhos sobre o conforto térmico humano nessa região. Nesse sentido, este projeto de doutorado se propõe também a avaliar o conforto térmico humano em um município do domínio climático semiárido, com o objetivo de revelar a situação térmica em lugares naturalmente quentes e que vivenciam o crescente processo de urbanização.

Sabendo-se hoje que o estudo climático apurado, associado ao desenvolvimento de técnicas para a convivência harmônica da humanidade com o clima e a natureza, é a chave para um futuro mais estável e menos vulnerável para o mundo e para o Brasil, da mesma forma que o sucesso no planejamento e gestão dos municípios brasileiros só será possível se as condições climáticas e suas relações complexas com a superfície forem consideradas nos planos diretores, optou-se neste projeto de doutorado pela realização do estudo climatológico na Geografia, especificamente pelo estudo dos campos hídrico e térmico, objetivando a geração de informações úteis ao planejamento e a gestão de um município do semiárido brasileiro, na finalidade de contribuir para não apenas com o “desenvolvimento" local, mas tendo como fim principal a busca por uma melhor qualidade de vida da população, pelo menos em se tratando da relação sociedade x clima.

Para gerar dados que contribuam ativamente com o planejamento e a gestão municipal do/no semiárido brasileiro, é imprescindível destacar as condições basilares desse ambiente, que têm como principais características elevadas temperaturas e a instabilidade das precipitações (AB SABER, 2003). As características climáticas e ambientais presentes no município de Caicó, que será nosso objeto de estudo dessa tese, são específicas do semiárido brasileiro, definido por Aziz Ab Saber (2003) como o "domínio dos sertões secos”. O Ministério do Meio Ambiente do Brasil, MMA (2007) delimitou este polígono dos sertões secos através das seguintes características: uma área com climas semiáridos e subúmidos, sujeita a intensas variações pluviométricas interanuais e que apresenta, de modo geral, alta susceptibilidade climática à desertificação (Índice de Aridez inferior a 0,50). Segundo 
dados da SUDENE (2015), atualmente mais 80\% dos municípios do estado do Rio Grande do Norte estão localizados neste polígono semiárido. Ver figura 01.

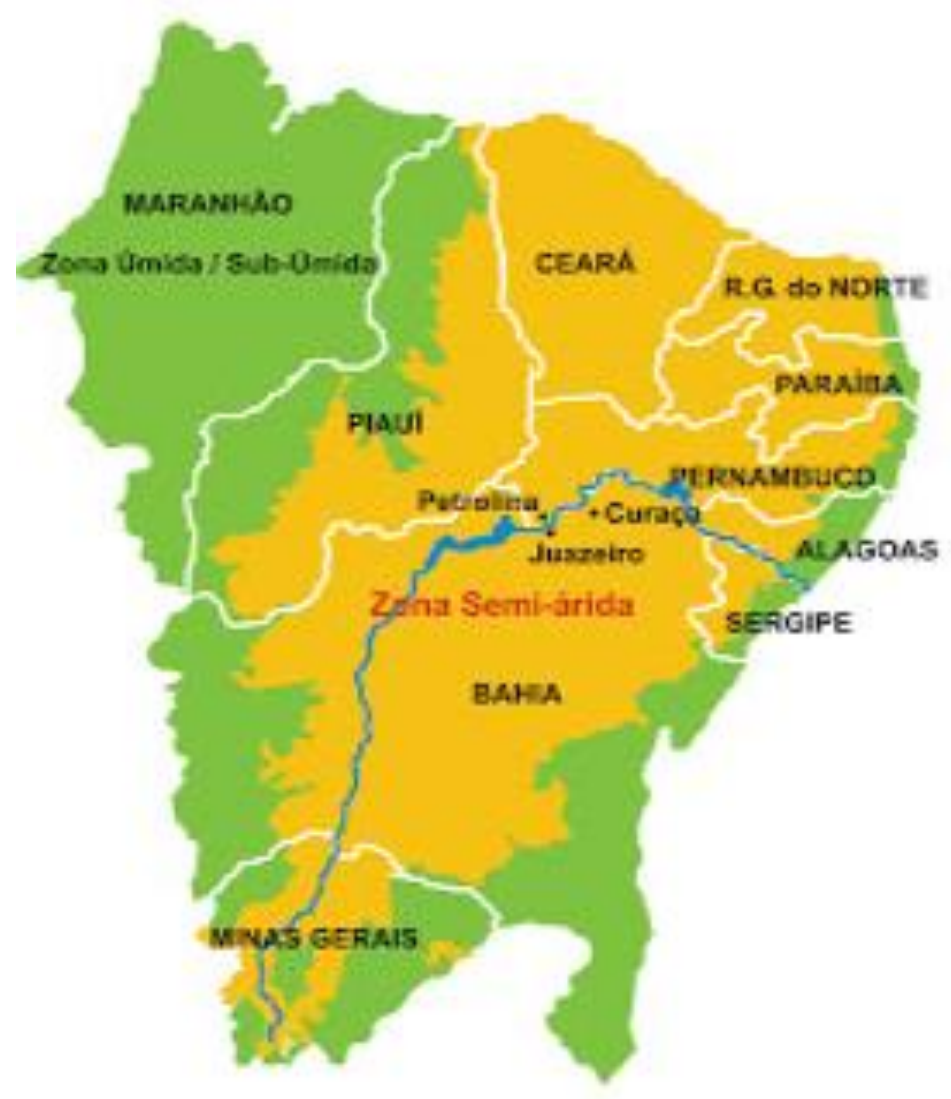

\section{Semi úmido / Sub-úmido}

\section{Semiárido}

Figura 1 Mapa com os dois grandes tipos climáticos predominantes no Nordeste brasileiro na atualidade. Em amarelo o polígono semiárido. Fonte: Embrapa semiárido.

As temperaturas nesta região do Brasil são, de modo geral, elevadas devido as condições descritas resumidamente a seguir:

A região Nordeste do Brasil (NEB), situada entre $1^{\circ}$ e $18^{\circ}$ de Latitude Sul e entre $34^{\circ} \mathrm{e}$ $48^{\circ}$ de Longitude Oeste (SUDENE, 2015), está entre a linha do Equador e o trópico de Capricórnio e logo sujeita anualmente a duas culminações zenitais do Sol, uma vez que a inclinação "fixa" de aproximadamente $23^{\circ}$ do eixo de rotação da Terra com relação ao movimento que ela realiza ao redor do Sol, limita a máxima intensidade de energia solar entre as latitudes de $23,5^{\circ} \mathrm{N}$ e $23,5^{\circ} \mathrm{S}$, com excesso no equador e déficit nos polos (AYOADE 2007; TORRES \& MACHADO, 2011)... As regiões do planeta Terra que 
se localizam nas baixas latitudes ou próximas das faixas tropicais, irão apresentar, de modo geral, as maiores temperaturas do globo oriundas da interação entre a energia solar e a superfície terrestre, e tais valores só serão modificados por influência de outros fatores geográficos, dos quais merece destaque a altitude...

...Como a região Nordeste do Brasil apresenta altitudes modestas, com o predomínio de planícies litorâneas, tabuleiros e depressões sertanejas, eis o motivo principal para o império das altas temperaturas anuais (LUCENA \& STEINKE, 2015, s/p).

Quanto à condição da instabilidade das precipitações e a condição de semiaridez, essas bem mais complexas de se entender, podem ser sintetizadas por uma combinação entre os padrões de circulação atmosférica e os fatores geográficos do clima, como descritos abaixo:

Muito mais complexa que a simples explicação para a origem das altas temperaturas presentes no NEB está a resposta para a semiaridez da região. Dentre as principais características geográficas do NEB têm-se as formas de relevo com relação aos ventos predominantes, a localização geográfica da região com relação as massas de ar atuantes e o albedo. Segundo Ab Saber (1999) "o Nordeste seco não é o império das chapadas. Em $85 \%$ do seu espaço total, a região semiárida brasileira se estende por depressões interplanálticas, situadas entre maciços antigos e chapadas eventuais sob a forma de intermináveis colinas sertanejas (p. 10)”. Assim estas depressões se escondem dos ventos úmidos oriundos do litoral que atingem as escarpas das chapadas e planaltos a eles direcionadas, subexpondo as depressões às massas úmidas provenientes do atlântico...

... Outra hipótese relaciona a origem da semiaridez do NEB à sua posição geográfica com relação às massas de ar atuantes. Edmon Nimer (1979) através de estudos sobre a circulação atmosférica argumentou que o NEB seria o "ponto final" de diversos sistemas de correntes atmosféricas perturbadas provenientes de Sul (frentes polares), de Norte (ZCIT), de Leste (Alísios) e de Oeste (Linhas de Instabilidade Tropicais). Em 2007, Mendonça \& Danni-Oliveira discorreram sobre o Nordeste trazendo o mesmo argumento de que as massas de ar Equatorial continental (MEC), Equatorial Atlântica (MEA), Tropical Atlântica (MTA) e Polar Atlântica (MPA) chegam no interior do Nordeste com umidade insuficiente. Ainda sob a explicação baseada nos fatores geográficos do clima, Molion \& Bernardo (2002) trazem a hipótese de Charney de que as superfícies semiáridas possuem albedo alto e refletem mais radiação que as áreas vizinhas, apresentando uma coluna troposférica relativamente mais fria, o que consequentemente inibiria a formação de nuvens convectivas (LUCENA \& STEINKE, $2015, \mathrm{~s} / \mathrm{p})$. 
Quanto as causas da instabilidade das precipitação e da semiaridez nordestina, as explicações baseadas nos sistemas de circulação atmosféricas mais aceitas atualmente estão ligadas as grandes migrações da Zona de Convergência Intertropical (ZCIT), agindo conjuntamente, ou não, com as teleconexões, à exemplo do El Niño Oscilação Sul (ENOS), assim como a formação, localização e tempo de duração dos Vótices Ciclonicos de Altos Níveis (VCANs). Tais sistemas exemplificam a complexidade climática na gênese da semiaridez do domínio dos sertões secos do Nordeste brasileiro, como destacado abaixo:

Vários estudos relatam a importância da ZCIT como sendo o principal mecanismo responsável pelas chuvas que ocorrem no norte do NEB entre fevereiro e maio (MOLION \& BERNARDO, 2002). Assim é a permanência por mais tempo da ZCIT mais ao norte ou mais ao sul que determina a qualidade da estação chuvosa na região semiárida (MOLION \& BERNARDO, 2002; MELO et al, 2009). As variações de posição e intensidade da ZCIT estão diretamente relacionadas às alterações nas posições e intensidades dos anticiclones subtropicais do atlântico norte (Açores) e do atlântico sul (Santa Helena). Estes, por sua vez são conduzidos pelas diferenças de pressão resultantes do recebimento de energia solar e das possíveis anomalias na temperatura na superfície do mar (ATSMs). As ATSMs positivas no atlântico sul e negativas no atlântico norte estão associadas a anos chuvosos e o oposto está associado a anos secos. Assim, em anos em que a ZCIT está ao sul da linha do equador e quando esta apresenta também uma banda dupla com forte nebulosidade, é certo que as chuvas serão intensas no semiárido Nordestino. Em contraponto, estando a ZCIT mais ao Norte, esta posição traria subsidência ao Sul (célula de Hadley) sobre o Nordeste, gerando tempo seco na região durante o período de inverno e primavera austral (BERNARDO \& MOLION, 2002)...

...Já com relação às teleconexões, Walker (1928) apud Kayano \& Andreoli (2009) documentou a coincidência entre o aquecimento anômalo das águas do pacífico equatorial leste e as secas no Nordeste brasileiro, quando um ramo ascendente forte provocado pela anomalia positiva do pacifico equatorial leste gera um ramo descendente sobre o oceano atlântico e o sobre o NEB, conhecido por circulação de Walker. Em condição de anomalia positiva (El Niño), há seca no Nordeste, em condição de anomalia negativa (La Niña), há chuva no Nordeste. No entanto Kayano \& Andreoli (2009) concordam que nos últimos anos, a interpretação mais aceita é a de que a variabilidade da temperatura da superfície do mar do atlântico tropical seja, de fato, determinante nas anomalias de precipitação do Nordeste, enquanto o ENOS, em 
determinadas ocasiões poderia reforçá-las ou enfraquecê-las. Por último, têm-se dado atenção ao Vórtice Ciclônico de Altos Níveis (VCAN). De acordo com Ferreira et al (2009), "os VCANs apresentam um centro relativamente frio, convergência de massa, movimentos verticais subsidentes no seu centro e ascendentes na periferia, e nebulosidade mais intensa principalmente na direção de seu deslocamento (p.43)". Para o NEB este vórtice está associado a nebulosidade e chuva e/ou a presença de céu claro, uma vez que ele traz chuva na sua periferia e céu claro no seu centro. Este sistema está associado tanto à Alta da Bolívia $(\mathrm{AB})$ quanto a Zona de Convergência do Atlântico Sul (ZCAS) e o mesmo atua principalmente durante o verão austral, início do período chuvoso no Nordeste seco, estando sua posição e intensidade também relacionados a variação pluviométrica no semiárido brasileiro (LUCENA \& STEINKE, 2015, s/p).

Desse modo, percebe-se que a região semiárida do Brasil possui características específicas como elevadas temperaturas durante todo o ano e alta vulnerabilidade hídrica devido a inconstância das chuvas, em conjunto com outras características de sua superfície, que dependem de uma série de fatores complexos os quais foram, resumidamente, mencionados acima.

Como o município de Caicó está inserido neste domínio de clima semiárido, as condições hídrico-climatológicas e termo-higrométricas devem ser levadas a cabo quando do planejamento e da gestão municipal, para que se consiga uma convivência estável e sadia da população neste ambiente.

\subsection{O objeto de estudo: o município de Caicó/RN}

Na região semiárida brasileira, a variabilidade das chuvas e o fenômeno das secas já são muito bem conhecidos e estudados no meio acadêmico, pois suas consequências são relatadas desde o período colonial (NIMER, 1979). O Nordeste semiárido, historicamente tem apresentado problemas de ordem social e ambiental fruto da influência mútua entre o clima, a exploração dos bens naturais e as condições sócio-econômicas e culturais que ali se instalaram. O Ministério do Meio Ambiente do Brasil, através de vários estudos realizados na região, delimitou o polígono das secas como sendo uma área "especial" devido as suas condições climáticas e outras condições naturais que resultam em situação de vulnerabilidade sócio-econômica devido à escassez de água (SANTANA, 2007).

Segundo dados do Censo Demográfico para o Semiárido Brasileiro (INSA, 2012), o espaço físico deste polígono abrange uma área de aproximadamente $980.133,079 \mathrm{~km}^{2}$, onde pelo menos um dos requisitos estabelecidos para sua delimitação seja atendido: precipitação média inferior a 800 
milímetros anuais; Índice de Aridez de até 0,50 e risco de seca maior que 60\%. Este polígono das secas, que atende a pelo menos um dos requisitos supracitados, abarca $11,53 \%$ do território brasileiro, sendo 56,46\% da região Nordeste e 11,09\% da região Sudeste do Brasil, contabilizando 1.135 municípios com uma população residente superior aos 22 milhões de habitantes (INSA, 2012). Cabe destacar que dos 1.135 municípios, 93,39\% são considerados de pequeno porte, com uma população entre 0 e 50.000 habitantes, $5,02 \%$ considerados de médio porte, com uma população entre 50.001 e 100.000 habitantes e apenas $1,59 \%$ dos municípios são considerados de grande porte, com uma população variando entre 100.001 e 900.000 habitantes, estando $65,23 \%$ da população residente no semiárido instalada em municípios de pequeno porte, 16,48\% em municípios de médio porte e 18,30\% nos grandes municípios (INSA, 2012).

O município de Caicó, objeto de estudo desta pesquisa, é um município de médio porte que está localizado no estado do Rio Grande do Norte (Figura 02), no domínio climático semiárido, dentro do polígono das secas, numa área que apresenta alta susceptibilidade ao processo de desertificação. Com uma população total de 62.790 habitantes, estando 57.461 instalados na área urbana do município e 5.248 na zona rural (IBGE, 2010), Caicó é o mais importante município da microrregião do Seridó Ocidental e é um dos mais importantes de toda a região do Seridó dos estados do Rio Grande do Norte e Paraíba devido ao forte desenvolvimento relativo às atividades comerciais, a pecuária, ao número de estabelecimentos de ensino, hospitais, além dos grandes eventos festivos como a festa de Sant'anna e o Carnaval. 
Universidade de Brasília

GEA - Departamento de Geografia PPG/GEA- Programa de Pós-Graduação

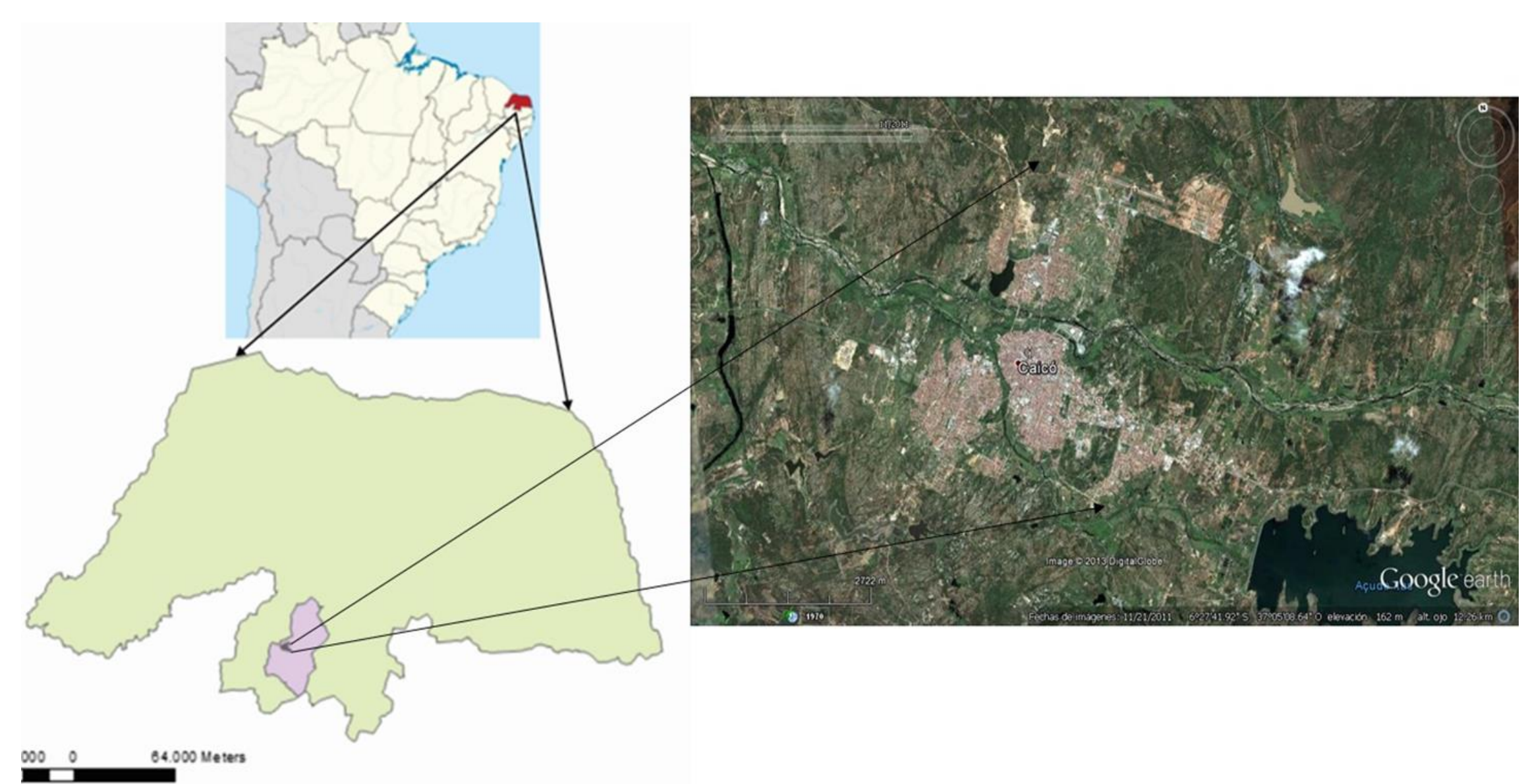

Figura 2 Mapa de Localização de Caicó no estado do Rio Grande do Norte e no Brasil, com destaque para o recorte municipal e a área urbanizada, com $o$ açude Itans, na imagem a direita.

Fonte: dados da pesquisa 
No contexto planetário, o município de Caicó está inserido na zona intertropical do globo, estando mais próximo da linha do equador que dos trópicos. Segundo Ayoade (2007), esta zona do planeta possui balanço de radiação positivo sendo o fotoperíodo praticamente constante, havendo aproximadamente 12 horas de dia e de noite durante todo o ano (VAREJÃO-SILVA, 2001). Ao nível médio do mar, as temperaturas dificilmente são inferiores ao $18^{\circ} \mathrm{C}$ e pode-se dizer que nesta zona não existe inverno de fato, ou seja, inverno com baixas temperaturas e precipitação de neve. Em se tratando da circulação geral da atmosfera, esta faixa do globo está sujeita à atuação constante dos ventos alísios de sudeste e nordeste, estando sob a ação dos movimentos sazonais da Zona de Convergência Intertropical (ZCIT) e estando praticamente protegida da atuação de massas de ar frias (NIMER, 1979). Assim sendo, em Caicó as estações do ano são mais bem identificadas pelos períodos chuvoso e seco do que pelas diferenças sazonais de temperatura (quente e frio), pois há baixa amplitude térmica.

Ao nível regional, Caicó está sob o domínio do clima tropical semiárido com regime de chuvas intermitente, com predomínio de forte insolação diária e anual e altas temperaturas (NUNES, 2006). Trata-se de uma região quente e subúmida/seca ou semiárida. Atuam como sistemas causadores das chuvas, ao nível regional: as Instabilidades Tropicais e os Complexos Convectivos de Mesoescala (geralmente associados à ZCIT); os Vórtices Ciclônicos de Altos Níveis (VCANs) e também as Ondas de Leste, sendo esta última responsável por grande parte das chuvas e nebulosidade que atuam no litoral leste do Nordeste brasileiro, porém dificilmente alcançam a depressão sertaneja favorecendo, desse modo, a condição de semiaridez no interior da região e, consequentemente, em Caicó.

Ao nível local, as chuvas, que são em grande parte de origem convectiva, interagem com os aspectos do solo, relevo e vegetação, promovendo o escoamento superficial rápido e também o rápido enverdecer da vegetação. Devido às condições climáticas estabelecidas no Nordeste semiárido, há, segundo Ab Saber (2003), uma fraca decomposição das rochas na região, com "malhadas" de chão pedregoso e com muitos afloramentos rochosos. A rede de drenagem é intermitente, relacionada ao ritmo desigual das precipitações. Segundo Ab Saber (2003), não existe termômetro melhor para delimitar o Nordeste seco do que os extremos da própria vegetação da Caatinga, rica em espécies arbustivo-arbóreas e cactáceas. No município de Caicó predominam, portanto, as condições climáticas descritas acima que operam desde o nível global ao local, como expostas na Figura 3. A Figura 4 mostra o aspecto dos solos e da vegetação predominantes no município. 


\begin{tabular}{|c|c|c|}
\hline$\underset{\substack{\downarrow \\
\downarrow}}{\text { Nível Global }}$ & $\underset{\downarrow}{\text { Nível Regional }}$ & Nível Local \\
\hline Faixa intertropical $\rightarrow$ & Região semiárida $\rightarrow$ & Depressão sertaneja \\
\hline$\underset{\downarrow}{\text { Ventos alísios / ZCIT }} \rightarrow$ & $\begin{array}{c}\text { Inst. Tropicais / (CCM)/ } \\
\text { Ondas de Leste }\end{array}$ & $\begin{array}{l}\text { Nuvens cúmulos e } \\
\text { cúmulos-nimbos }\end{array}$ \\
\hline $\begin{array}{c}\text { Época de atuação da } \\
\text { ZCIT }\end{array}$ & Regime temporário & Chuvas localizadas \\
\hline
\end{tabular}

Figura 3 Condições climáticas e meteorológicas atuantes em Caicó/RN, escala sinótica e local Fonte: autoria própria

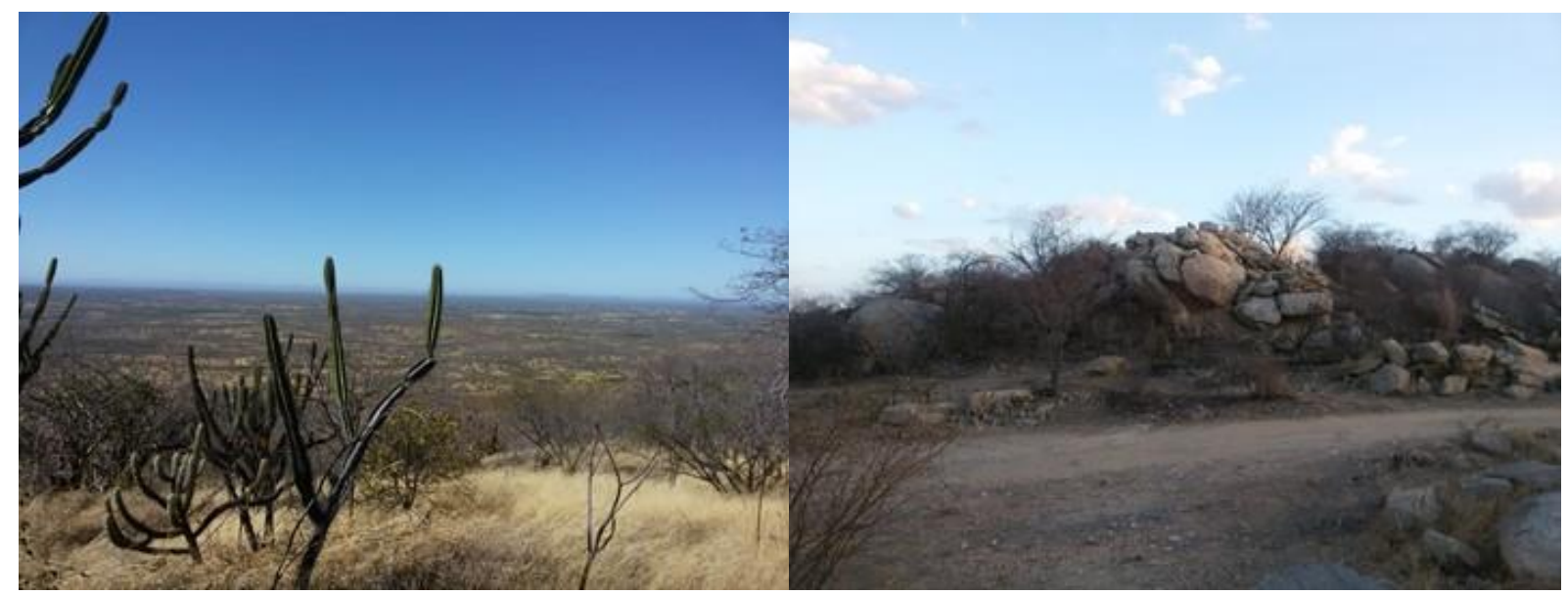

Figura 4 Aspecto da Caatinga no município de Caicó. Em (a) vista da depressão sertaneja a partir da serra de São Bernardo; Em (b) aspecto de um afloramento rochoso (lajedo) muito comum na Caatinga do Seridó.

Sob essas condições naturais de semiaridez, onde predominam solos pouco desenvolvidos e pedregosos e vegetação Caatinga xerófila, ocorreu o processo de colonização do semiárido brasileiro que resultou na formação de aglomerados urbanos que vieram a formar as cidades de pequeno e médio portes, como Caicó. As implicações do processo de urbanização crescente numa região naturalmente vulnerável devido às suas características climáticas e naturais recaem sobre a exploração dos bens naturais relacionado ao crescimento das cidades e ao modo de produção capitalista baseado na exploração da natureza para um excessivo e desnecessário consumo de bens materiais (FRANCISCO, 2015). 
Como nas demais cidades do semiárido nordestino, o processo de crescimento de Caicó surgiu a partir da colonização do sertão, com o estabelecimento de fazendas próximas aos rios, onde, com o mais recente processo de urbanização, o improviso prevaleceu o planejamento, corroborando com Monteiro (2003), quando este discute o processo de urbanização das cidades brasileiras.

No estado do Rio Grande do Norte, semelhante a outros estados do Nordeste, como Paraíba e Pernambuco, o processo de ocupação pelos europeus se deu a partir do ano de 1500 quando o avanço de novas técnicas possibilitou as viagens nas caravelas. Os europeus desembarcaram no litoral nordestino onde se estabeleceram, e passaram a cultivar a cana-de-açúcar. A partir de 1700, quando foi proibida a criação de gado próximo aos canaviais, os colonizadores seguiram para o interior acompanhando o caminho dos rios (FARIA, 2011). É nesse período que o sertão passa a ser colonizado, a partir da criação das Ribeiras (Distritos rurais com várias fazendas de gado), e assim começam a crescer os povoados e vilas.

Dessa forma, através da instalação da pecuária e da criação de pontos de abrigo para os militares (MACÊDO, 2005) próximos aos rios, o sertão passa a ser ocupado e consequentemente, o lugar onde hoje se encontra a cidade de Caicó também, como colocado por Faria, (2011):

Assim tudo começou, de fato, na vila do Príncipe, por volta de 1788, mas foi no dia 15 de dezembro de 1868, que o governador da província, Manoel José Marinho, assinou a Lei Provincial No 612, que elevou a "Vila nova do Príncipe" à categoria de cidade... Assim, vemos que as alterações na composição daquele "embrião urbano", se davam lentamente, mas apresentava forte relação com o mundo externo (pag 89).

E continua:

O uso do território no qual foi gestada a cidade de Caicó resulta, portanto, da distribuição das sesmarias e datas, destinadas à propriedade privada. O território como uso e o território como recurso pertencem agora a novos agentes, que porão em prática o criatório, uma agricultura de subsistência, estas como atividades atreladas à economia litorânea... Porão em prática também um sistema de povoação (pag. 91).

Por muitos anos, Caicó permaneceu com seu lento crescimento. Segundo Moraes (1999), no inicio do século XX o algodão irá aparecer como uma espacialidade do território urbano de Caicó, incluindo o processo de beneficiamento que transforma o algodão em fibra têxtil. Este processo gerou um crescimento significativo na economia do município. Foi entre os anos de 1930 e 1970 que a cidade 
cresceu de forma intensa e avançou para além dos dois rios que antes a limitavam. Esse crescimento foi impulsionado pela cotonicultura, pelo beneficiamento das sementes do algodão e de outras intencionalidades que despertaram para o uso de um território dinamizado (FARIA, 2011). O crescimento urbano de Caicó entre os rios Seridó e Barra Nova começa a extrapolar os limites naturais. A Figura 05 mostra a evolução urbana do município de Caicó através de várias plantas da cidade.
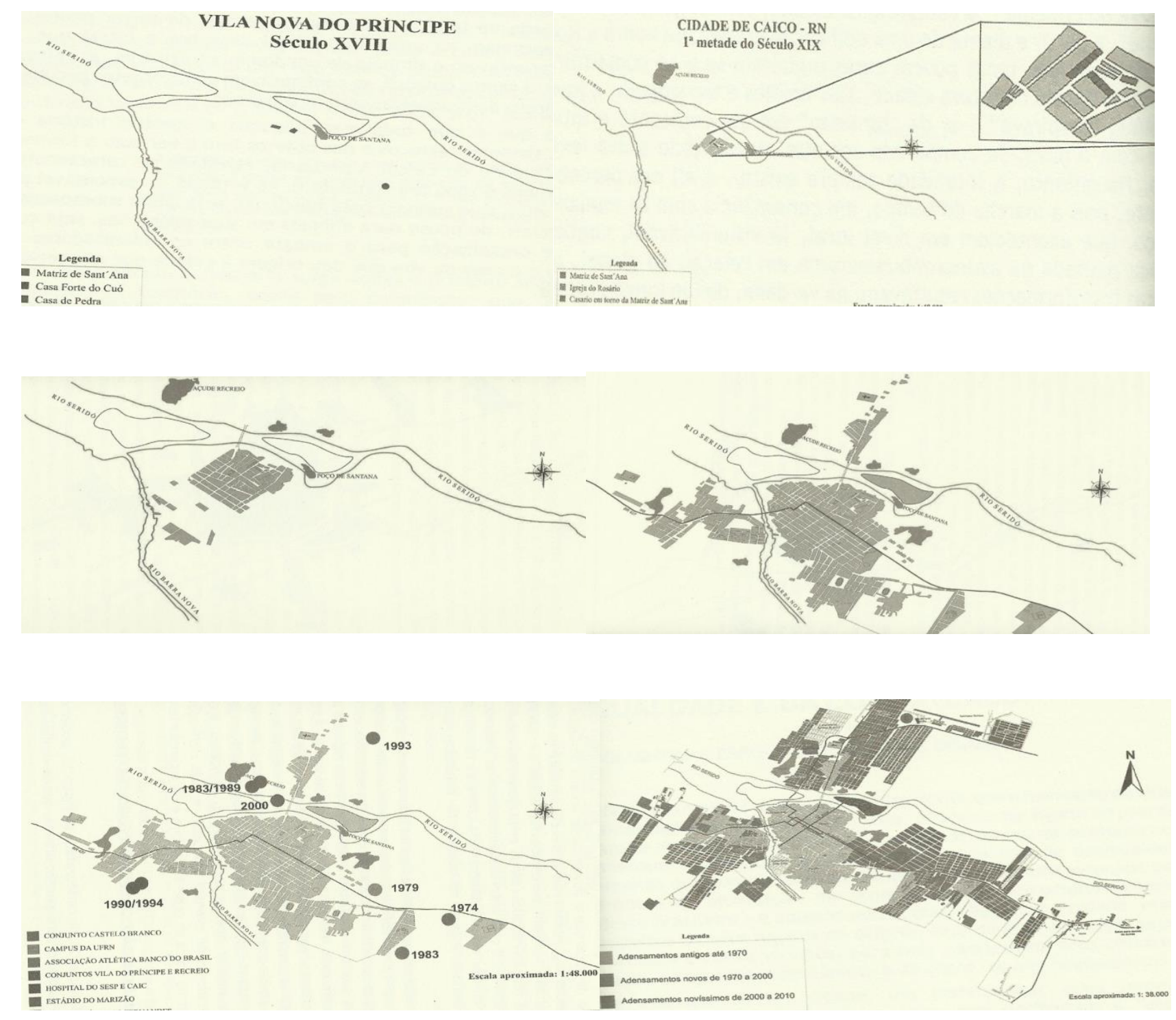

Figura 5 Plantas da cidade de Caicó mostrando a evolução histórica da urbanização. Notam-se, nas imagens, os rios Seridó e Barra Nova.

Na figura 5 pode-se perceber em (a) Século XVIII embrião da cidade no período da pecuária; Em (b) $1^{a}$ metade do século XIX, período da Pecuária; Em (c) mancha urbana em 1950, período de ascensão algodoeira; Em (d) mancha urbana em 1970, início do declínio do algodão; Em (e) eventos implantados 
a partir da década de 1970; Em (f) ocupação dos adensamentos urbanos gerados a partir de eventos diversos (FARIA, 2011).

As características da paisagem urbana de Caicó não são diferentes das de outras cidades próximas, também localizadas no semiárido nordestino. Com a expansão urbana, a construção de casas e pequenos estabelecimentos comerciais se deram próximas às áreas de várzea e ao leito dos rios. Geralmente essas áreas são habitadas por pessoas das classes média e baixa, mas algumas vezes, pessoas de alto poder aquisitivo também se estabelecem em áreas às bordas de rios e açudes.

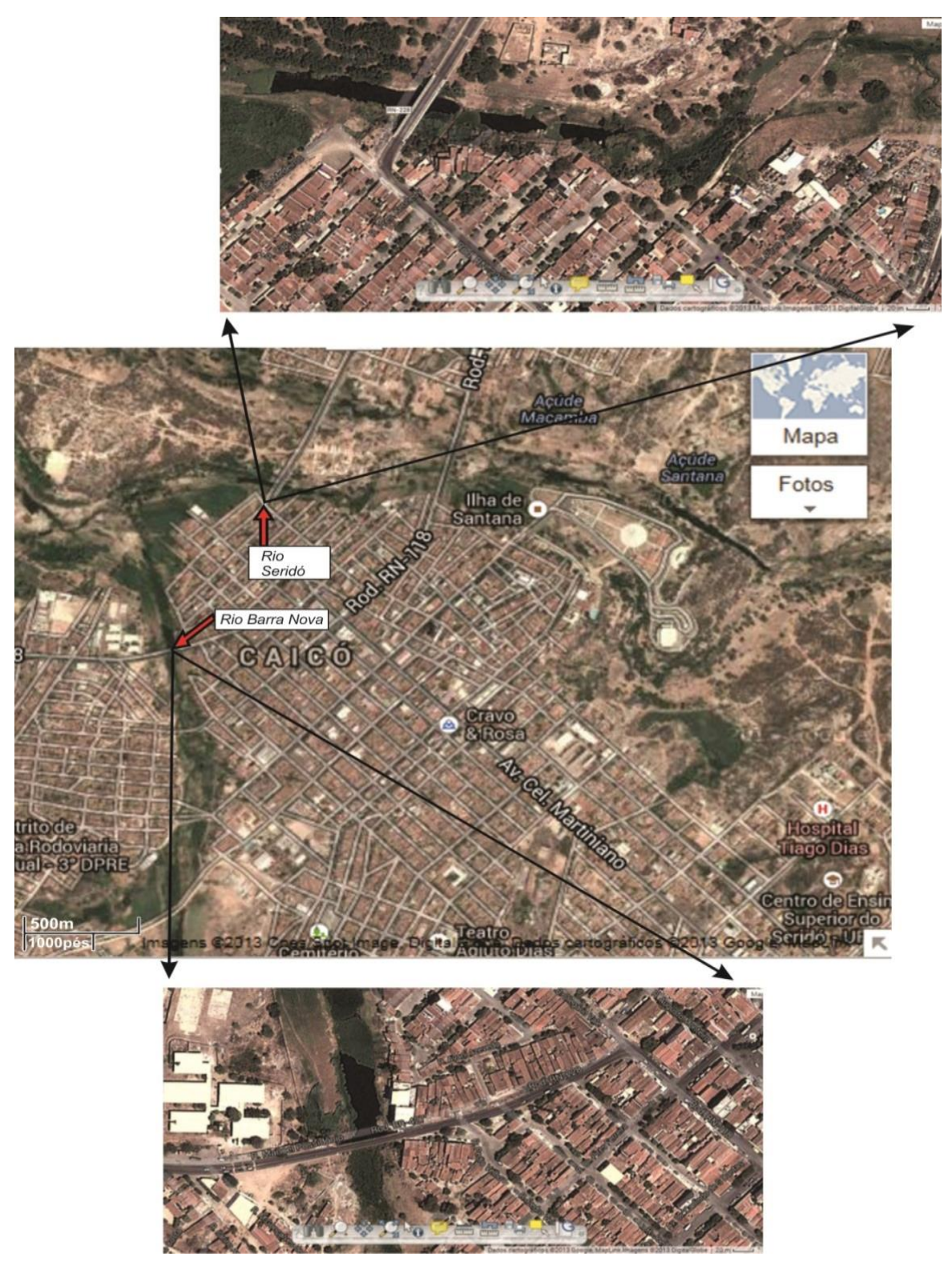

Figura 6 Tomada da área urbana do município de Caicó onde se podem ver inúmeras construções às margens dos rios Seridó e Barra Nova. Fonte: Google Earth, 2013. 
A Figura 06 é uma imagem de satélite de 2013 que mostra a densidade de edifícios em Caicó na atualidade, tanto entre os rios quanto às margens dos rios Seridó e Barra Nova, assim como mostra pouquíssimas áreas verdes comprovando a fraca arborização urbana. Como se pode observar nas Figuras 05 e 06, atualmente em Caicó muitas moradias estão localizadas próximas aos rios Seridó e Barra Nova da mesma forma que se percebe alta densidade de construções entre estes dois rios. A substituição da vegetação original, a natureza dos materiais de construção utilizados, a fraca arborização urbana, bem como o próprio desenho urbano da cidade e seu crescimento, acabam por exigir uma maior demanda por água ao mesmo tempo em que tendem a originar bolsões de calor, que podem aumentar o grau de desconforto e vulnerabilidade da população residente nos aglomerados urbanos devido ao calor, principalmente em regiões semiáridas quentes.

Desse modo, o estudo das condições hídricas e térmicas da cidade de Caicó/RN poderá fornecer indicadores úteis, tanto para o presente quanto para o futuro do município, além de servir de base para o planejamento e a gestão municipal de outras cidades com condições climáticas e geográficas similares.

\subsection{Objetivos da pesquisa e estrutura do trabalho}

O objetivo principal dessa tese de doutorado foi analisar o comportamento climático do município de Caicó/RN/Brasil, dando ênfase às situações hidroclimatológica e higrotérmica, com a finalidade de gerar subsídios ao planejamento e gestão municipal, visando ações do governo e da sociedade que, combinadas com os elementos do clima supracitados, estejam arraigadas à qualidade de vida da população.

Os objetivos específicos dessa tese foram:

> Analisar as condições hidroclimatológicas do município de Caicó através de dados históricos de precipitação, evaporação e evapotranspiração potencial;

> Diagnosticar o comportamento das chuvas e a situação de vulnerabilidade hídrica do município por meio da utilização de técnicas estatísticas, geoestatísticas e de índices climáticos;

Analisar as condições higrotérmica do município de Caicó através de dados de temperatura do ar, umidade relativa do ar e da velocidade do vento; 
Diagnosticar o grau de conforto humano no município de Caicó através de análise estatística e da aplicação de índices bioclimáticos;

$>$ Analisar as condições termo-higrométricas da área urbana do município no intuito de se identificar as áreas mais confortáveis/desconfortáveis da cidade;

$>$ Trazer sugestões para ações efetivas que visem o bem estar da população e sua convivência estável e sadia com o clima local, na perspectiva dos campos hídrico e térmico

Para cada objetivo específico formulado, procurou-se gerar resultados confiáveis, os quais puderam ser alcançados por meio do método científico. Conforme relatado por Marconi; Lakatos (2006), o método científico pode ser definido como o conjunto de atividades sistemáticas e racionais que, com maior segurança e eficiência, permite alcançar o objetivo, gerando conhecimentos válidos e verdadeiros e delineando o caminho a ser seguido, detectando erros e auxiliando as decisões do cientista. Logo, dentro do objetivo geral do trabalho, para cada objetivo específico traçado procurouse trabalhar com uma fundamentação teórica apropriada e contemporânea, e com a aplicação de métodos e técnicas adequados ao tema em questão, sob o conhecimento científico do clima e de sua interação com a superfície, que é produto da investigação científica da Climatologia e da Geografia.

Sob esse contexto, buscou-se realizar uma análise dos dados meteorológicos registrados no município de Caicó selecionando as variáveis que melhor atendessem ao objetivo do trabalho, para em seguida, tabular, calcular, mapear e interpretar os números obtidos a partir dos dados meteorológicos e dos trabalhos de campo realizados. Os dados climatológicos foram provenientes do INMET (2009, 2015), EMPARN (2014) e SUDENE (2015), além dos equipamentos instalados durante esta pesquisa. As técnicas estatísticas, geoestatísticas, a aplicação de índices climáticos e bioclimáticos, a instalação de equipamentos, a leitura e interpretação de imagens de satélite e os trabalhos de campo foram eleitos para a realização do diagnóstico climático do município de Caicó, sendo considerados de fundamental importância para o alcance de resultados confiáveis sobre as condições hídrico-climatológicas e termohigrométricas e sua interação com os aspectos antrópicos no município.

As variáveis escolhidas, assim como os métodos e técnicas utilizados nesta pesquisa constam explicados em cada artigo científico que compõe o corpo do texto, assim dividido: Capítulo 2: o campo hidroclimatológico composto por 2 artigos; Capítulo 3: o campo higrotérmico composto por 2 artigos; Capítulo 4: um registro de software como produto e por último as considerações finais e perspectivas. 


\section{Referencias Bibliográficas}

AB’SABER, A. N. Dossiê Nordeste seco. Estudos avançados. v. 13. n. 36, pág 5- 59, 1999.

, A. N. Caatingas: O domínio dos sertões secos. In: Os domínios de natureza no

Brasil: potencialidades paisagísticas. $1^{\text {a }}$ Ed. São Paulo: Ateliê Editorial, 2003.

AYOADE, J. O. Introdução à climatologia para os trópicos. $12^{\mathrm{a}}$ Ed. Rio de Janeiro: Bertrand Brasil, 2007.

IBGE/BRASIL. 2010. Instituto Brasileiro de Geografia e Estatística. “IBGE Estados.”, Acessado em outubro de 2013. Disponível em: http://www.ibge.gov.br/estadosat/perfil.php?sigla=rn

BRASIL. 2013. Ministério do Desenvolvimento Agrário. Sistema de Informações Territoriais. Índices de Desenvolvimento do Seridó - RN.

$\mathrm{http}: / /$ sit.mda.gov.br/territorio.php?ac $=$ buscar\&base $=1 \&$ abr $=$ uf\&regiao $=\& u f=R N \&$ territorio $=76 \&$ te ma $=6$. Acessado em maio de 2013.

CEPED/UFSC - Centro Universitário de Estudos e Pesquisa sobre Desastres/Universidade Federal de Santa Catarina. Atlas brasileiro de desastres naturais: volume Brasil 1991-2010. Florianópolis: CEPED/IBGE, 2012. 94p.

DIAS, M. A. F. da S.; SILVA, M. G. A. J. da 2009. Para entender o Tempo e Clima. In: Tempo e Clima no Brasil, Cavalcanti (org), 2009.

EMPARN - Empresa de Pesquisa Agropecuária do RN - EMPARN Gerência de Meteorologia. Climatologia Rio Grande do Norte. Disponível em:

$<$ http://189.124.201.150/climaRN/medias historicas_municipios_RN.htm>, Acesso em: 10/10/2014.

FARIA, Carlos Eugênio de. Os eventos geográficos e a expansão urbana de Caicó. Natal: Editora do IFRN, 2011.

IDEMA. Instituto de Desenvolvimento Sustentável e Meio Ambiente do Rio Grande do Norte. Aspectos Físicos do RN. Disponível em:

www.idema.rn.gov.br/governo/secretarias/idema/.../Aspectos-fisicos.pdf. Acesso em: Maio 2012.

INMET. 2015. "BDMET: Banco de dados Meteorológicos”. Acessado em abril April 2015. Disponível em: http://www.inmet.gov.br/.

INSA - Instituto Nacional do Semiárido. Sinopse do censo demográfico para o semiárido brasileiro. Salomão de Sousa Medeiros [et al]. Campina Grande: INSA, 2012. 103p.

LUCENA, R. L., STEINKE, E. T. Diagnóstico climático para o município de Caicó/RN com ênfase à disponibilidade de água no sistema-superfície-atmosfera. Anais.. X Simpósio Brasileiro de Climatologia Geográfica, Curitiba, 2014. 1577-1587p.

MACEDO, Muirakytan Kennedy de. A penúltima versão do Seridó: espaço e história no regionalismo seridoense. Natal: Ed Sebo Vermelho, 2005. 
MALVEZZI, R. Semi-Árido: uma visão holística. Brasília: Confea, 2007.

MARCONI, lakatos, 2006. Metodologia científica.

MENDONÇA, F \& DANNI-OLIVEIRA. Climatologia: Noções básicas e climas do Brasil. São Paulo: Oficina de Textos, 2007.

MENDONÇA E DANNI-OLIVEIRA. Climatologia nocçoes básicas e climas do Brasil , 2007.

MONTEIRO, C. A. de F. Teoria e Clima Urbano: um projeto e seus caminhos. In: , C. A. de F.; MENDONÇA, Francisco. Clima Urbano. São Paulo: Contexto, 2003.

MORAES, Ione Rodrigues Diniz. Desvendando a cidade: Caicó em sua dinâmica espacial. Natal: Senado, 1999.

NIMER E. Circulação atmosférica do Nordeste e suas consequências: o fenômeno das secas. In: Climatologia do Brasil. Rio de janeiro: IBGE, 1979.

1979.

, E. Climatologia da Região Nordeste. In: Climatologia do Brasil. Rio de janeiro: IBGE,

NUNES, Elias. Geografia física do Rio Grande do Norte. Natal: Imagem Gráfica, 2006.

OLIVEIRA, Marcos José de, and VECCHIA, Francisco. 2010. Elaboração de normais climatológicas: Caracterização e tendências de temperatura em Itirapina - SP, Brasil. Anais.. XVI CBMET, Sociedade Brasileira de Meteorologia. Pará, Belém: setembro, 13 - 17. 2010.

FRANCISCO, Papa. Laudato Si’ Carta encíclica: sobre o cuidado da casa comum. $1^{\text {a }}$ Ed. São Paulo: Paulinas, 2015.

SANTANA, Marcos Oliveira (Org). Atlas das áreas susceptíveis à desertificação do Brasil. Brasília: Ed: MMA - Ministério do Meio Ambiente, 2007.

SUDENE, Superintendência do Desenvolvimento do Nordeste. Semiárido. Disponível em: http://www.sudene.gov.br/acesso-a-informacao/institucional/area-de-atuacao-da-sudene/semiarido Acessado em 01 Set 2015.

TORRES, F. T. P.; MACHADO, P. J. de O. Introdução à Climatologia. São Paulo: Cengage Learning, 2011.

TROPPMAIR, H. Biogeografia e meio ambiente. Rio Claro: Graffset, 2004.

VAREJÃO-SILVA, M. A. Meteorologia e Climatologia. $2^{\text {a }}$ Edição. Brasília: INMET, 2001. 


\section{CAPÍTULO 2 A condição Hidroclimatológica}

Este capítulo tem como objetivo apresentar os resultados do estudo climático focado na questão hídrica do município de Caicó no formato de dois artigos.

O primeiro artigo, "Comportamento hidroclimatológico do estado do Rio Grande do Norte e do município de Caicó”, discute as condições hídricas do estado do Rio Grande do Norte e de Caicó a partir de variáveis meteorológicas, tais quais a precipitação, evaporação e evapotranspiração potencial. A ideia deste artigo será apresentar um panorama da realidade climática do estado do Rio Grande do Norte para assim desvelar as especificidades do município de Caicó. Para tanto, utilizaram-se técnicas de estatística descritiva, aplicação do método dos quartis, a análise geoestatística através do Coeficiente de Redistribuição e a aplicação de índice de Aridez.

O segundo artigo, "Variabilidade climática no município de Caicó/RN: secas e chuvas num arquétipo do clima semiárido do Nordeste brasileiro" publicado ${ }^{1}$ na Revista de Climatologia e estudos da paisagem da UNESP, teve por objetivo analisar uma serie histórica do período de cem anos de precipitação no município de Caicó, além de discutir os sistemas de circulação atmosférica responsáveis por anos chuvosos/secos assim como a dinâmica anual e interanual das chuvas no município. Nesse sentido foram realizadas técnicas de estatística descritiva, elaboração de normais climatológicas, análise de tendência por regressão e aplicação de Índice de Aridez.

${ }^{1}$ LUCENA, R.L. , FERREIRA, A.M. , FERREIRA, H.F.P.A., STEINKE, E.T. Variabilidade climática no município de Caicó/RN: secas e chuvas num arquétipo do clima semiárido do Nordeste brasileiro. Revista Climep. Rio Claro, v. 8, n. 1, janeiro/junho/2013, p. 37 
2.1 Artigo 1 Comportamento hidroclimatológico do estado do Rio Grande do Norte e do município de Caicó

Autoria: Rebecca Luna Lucena; Ercília Torres Steinke

\title{
Resumo
}

Este artigo tem por objetivo principal analisar o comportamento das chuvas no estado do Rio Grande do Norte e no município de Caicó no intuito de gerar subsídios à gestão dos recursos hídricos locais. Para tanto, foram coletados dados pluviométricos de todos os municípios do estado do Rio Grande do Norte e dados de precipitação, evaporação e evapotranspiração do município de Caicó. Para a análise hidroclimatológica foram consultados trabalhos sobre o tema, aplicadas técnicas estatísticas, o Índice de Aridez e análise geoespacial, através do método dos Quartis e do Coeficiente de Redistribuição. Os resultados das análises espaciais foram representados em mapas elaborados no programa ArcGis 10.0. Os dados analisados mostraram que há uma distribuição espacial irregular das chuvas no estado do Rio Grande do Norte onde as mesmas são mais volumosas no litoral leste, seguido pelo oeste do estado, sendo a região central do estado (que inclui parte do litoral norte) a mais seca. Percebeu-se também que a distribuição espacial da precipitação apresenta a mesma estrutura tanto em anos secos como em anos chuvosos, com os maiores valores no litoral leste, seguido pelo oeste do estado e as áreas serranas do sertão, sendo a região central aquela que detém os menores valores. Para o município de Caicó, verificou-se que o mesmo foi classificado como semiárido e com alta susceptibilidade climática ao processo de desertificação, porém o mesmo se encontra numa faixa de transição com característica de clima menos árido que o da mesorregião Central potiguar.

Palavras-chave: Rio Grande do Norte, Caicó/RN, precipitação, Quartis, Índice de Aridez

\begin{abstract}
The main goal of this study is to analyze the rain behavior on the state of Rio Grande do Norte and in the city of Caicó in order to offer subsidies for the management of local water resources. For this purpose, precipitation data from all the 167 municipalities of Rio Grande do Norte state was collected and precipitation, evaporation and evapotranspiration data was collected from Caico city. For the hydroclimatological analysis we used statistical techniques, the aridity index and the geospatial analysis, applying the Quantile and the Redistribution coefficient methods. The results of the spatial analysis were plotted on maps designed with ArcGIS 10.0. Data analyzed showed an unequal distribution of rainfall at the Rio Grande do Norte state, being larger on the east coast, followed by the west of the state, and the central region of the state (which includes part of the north coast), the droughtiest area. It is also realized that the Rio Grande do Norte state has the same spatial structure in dry and wet years, concentrating rains on the east coast, followed by the west, in the mountainous areas of the hinterland, and the drier in central region. Caico city was classified as semi-arid with high climatic susceptibility to desertification process, but it's located in a transitional climatic range, which is less arid than Central area of RN state.
\end{abstract}

Keywords: Rio Grande do Norte, Caicó / RN, precipitation, Quantile, Aridity Index 


\section{Introdução}

As condições hídricas e a disponibilidade de água para consumo humano e animal, dependem, entre vários fatores, da quantidade de água precipitada (chuvas), da quantidade de água evaporada (evaporação e evapotranspiração), assim como da capacidade de absorção de água pelo solo (por meio dos processos de infiltração e percolação). A disponibilidade de água também depende das ações humanas, seja no seu armazenamento, tratamento e utilização, que se feitos de modo inadequado, expõem a população à situação de risco, tanto devido à quantidade, como à qualidade das águas (REBOUÇAS, 2002; DREW, 2005). As águas da chuva, além de serem a fonte original das reservas de águas superficiais (CALASANS et al, 2008) utilizadas para suprir as necessidades humanas e animais, são responsáveis pelos processos erosivos, formação dos solos e manutenção da vegetação nativa. Devido a sua grande importância em todos os aspectos acima citados, o estudo do comportamento das chuvas talvez seja um dos mais analisados e difundidos na Climatologia, assim como os estudos sobre a temperatura do ar. Para se estudar as chuvas, técnicas estatísticas e geoestatísticas vêm sendo, desde longa data, utilizadas e aprimoradas, assim como modelos matemáticos e computacionais que buscam cada vez mais o melhoramento das previsões do tempo e do clima (OLIVEIRA, 2010). Assim, esses estudos do comportamento das chuvas, tanto da quantificação quanto da espacialização, bem como da previsão, fornecem informações importantes para a gestão adequada dos recursos hídricos por parte dos governos e da sociedade.

Sabe-se que, em regiões sub-úmidas e semiáridas, a questão da água é crucial para o desenvolvimento local e para a manutenção da qualidade de vida, uma vez que nessas áreas tal recurso é mais escasso que nas área úmidas e hiperúmidas. No Brasil, a Região Nordeste possui um núcleo de semiaridez há muito tempo conhecido e que já sofreu várias delimitações. Tal região denominada de semiárido brasileiro (SUDENE, 2015), polígono das secas (MMA, 2007), Domínio dos sertões secos (AB’ SABER, 2003), é possuidora de um clima que varia desde subúmido à semiárido, marcado pela escassez e irregularidade das chuvas associada às altas taxas de evaporação. No Estado do Rio Grande do Norte tais condições de subumidade e semiaridez são prevalecentes, o que coloca o estado em situação de alerta quando trata-se da disponibilidade hídrica para os múltiplos usos. Como as condições de semiaridez são predominantes, esta condição natural acaba por abranger importantes centros urbanos no interior, como importantes cidades de médio e pequeno porte a exemplo de Mossoró, Pau dos Ferros, Currais Novos, Macau e Caicó, esta última eleita neste trabalho como a área de interesse. 
Diante deste quadro, neste trabalho, objetivou-se analisar as condições hídricas do estado do Rio Grande do Norte e do município de Caicó para fornecer subsídios à gestão adequada das águas, tanto ao nível municipal, quanto estadual. Para tanto, foram consultados trabalhos científicos sobre o tema, utilizados dados de precipitação, evaporação e evapotranspiração, realizadas análises estatísticas e geoestatísticas, como descritas a seguir.

\section{Metodologia}

Para se atingir os objetivos deste trabalho foram realizadas as seguintes etapas metodológicas: Coleta dos dados de precipitação de todos os municípios do estados do Rio Grande do Norte do período de 1963 a 2013, incluindo a média anual, a escolha de um ano chuvoso (2009) e um ano seco (2013); aplicação de técnicas estatísticas e geoestatísticas para o RN, através do método dos Quartis e do Coeficiente de Redistribuição; coleta e organização dos dados de precipitação, evaporação e evapotranspiração do município de Caicó/RN do período de 1996 a 2013; aplicação de técnicas estatísticas, como probabilidade, tempo de retorno e Índice de Aridez para o município de Caicó.

\section{Coleta e organização dos dados de precipitação dos municípios do estado do Rio Grande do Norte}

Para a análise hidroclimatológica foram coletados os dados de precipitação de todos os municípios do estado do Rio Grande do Norte. Os mesmos foram adquiridos na Empresa de Pesquisa Agropecuária EMPARN (2014) a partir dos postos pluviométricos municipais. Para as análises foram selecionados três anos-padrão: um habitual, um chuvoso e um seco, seguindo a metodologia exposta por Sant' Anna Neto (1990) apud Lucena et al, (2012), onde o ano habitual possua pluviosidade dentro dos desvios médios padrão, variando de $-12,5 \%$ a 12,5\% com relação a média; o ano chuvoso possua precipitações superiores a $25 \%$ da média normal e o ano seco possua índices inferiores a $-25 \%$ da média normal (LUCENA et al, 2012).

Para realizar as análises estatística e geoestatística, coletou-se então a média anual por município (normal climatológica 1963-2013), assim como os valores totais anuais por município de um ano eleito como o chuvoso, nesse caso o ano de 2009, e outro eleito como seco que foi o ano de 2013, conforme a metodologia descrita acima. Para o preenchimento das falhas utilizou-se o método de ponderação regional proposto por Tucci (2002). 
Aplicação do método dos Quartis e do Coeficiente de Redistribuição para o estado do RN

As separatrizes são medidas baseadas na ordenação dos dados e que dividem um certo número de valores em partes iguais. Os quartis são separatrizes que dividem um conjunto em 4 partes iguais. O Primeiro Quartil ou Quartil Inferior (Qi), é um valor que delimita os 25\% menores valores de um conjunto de dados (f.01). A Mediana ou Segundo Quartil (Md) separa os 50\% maiores dos 50\% menores valores. O Terceiro Quartil ou Quartil Superior (Qs) é o valor que delimita os 25\% maiores valores (REIS, 2015). (f.02)

$$
\text { Pos.Qi }=(n+1) / 4(f .01)
$$

Onde: $Q i$ é o Quartil inferior e $n$ é o número total de elementos da amostra

$$
\text { Pos.Qs }=[3 \mathrm{x}(\mathrm{n}+1)] / 4(\mathrm{f} .02)
$$

Onde: $Q s$ é o quartil superior e $n$ é o número total de elementos da amostra

O coeficiente de redistribuição $\mathrm{Rk}(\mathrm{t}, \mathrm{s})$ é associado a uma atividade Ak e compara a distribuição espacial dessa atividade em dois períodos diferentes (período t e período $\mathrm{s}$ ) (f. 03). $\mathrm{Rk}=1 \mathrm{~A}$ atividade Ak sofreu completa redistribuição espacial entre os períodos $\mathrm{t}$ e $\mathrm{s}$. $\mathrm{Rk}=0 \mathrm{~A}$ atividade $\mathrm{Ak}$ em nada alterou sobre a estrutura espacial nos períodos t e s (SOUZA \& ALVES, 2011).

$$
\mathrm{R}_{\mathrm{k}}^{(\mathrm{t}, \mathrm{s})}=\frac{1}{2} \sum_{\mathrm{r}=1}^{\mathrm{n}}\left|p_{\mathrm{rk}}^{(\mathrm{t})}-p_{\mathrm{rk}}^{(\mathrm{s})}\right|
$$

Onde: $R$ é o Coeficiente de redistribuição, $k$ é a atividade em questão, $n$ são os $n$ espaços geográficos, $t$ é um período t, $s$ é o período de tempo s e $r k$ é o \% da atividade $k$ no espaço $r$.

Coleta e organização dos dados de precipitação, evaporação e evapotranspiração do município de Caicó/RN

Os dados de precipitação cobrem um período de 100 anos desde 1911 até 2010. Estes foram conseguidos através das microfichas da SUDENE e também através da EMPARN e EMATER. Já os dados de evaporação coletados no município abarcam o período de 18 anos, de 1996 à 2013 e os dados de evapotranspiração abarcaram o período de 2003 até 2013, ambos conseguidos junto ao INMET 
através da estação climatológica principal do Seridó (Caicó) e no banco de dados BDMET, disponível no site do INMET (2015), http://www.inmet.gov.br/portal/index.php?r=bdmep/bdmep.

\section{Probabilidade, Tempo de Retorno e Índice de Aridez para o município de Caicó}

“Considerando o lançamento de um dado, o conjunto de todos os casos possíveis de ocorrer é o conjunto das possibilidades" (FRANCISCO, 1995, p.45). Para se chegar aos valores de probabilidade, deve-se distribuir os dados em classes e expressar a relação entre o número de vezes que determinado fenômeno ocorreu e o número total de eventos observados (GALVANI, 2005) (f.04).

$$
P=f r=\text { na/n (f.04) }
$$

Onde: $P$ é a probabilidade, $f r$ é a frequência relativa, $n a$ o número de vezes que determinado evento aconteceu e $n$ o número total de elementos da série

Já o Tempo de Retorno expressa um intervalo de tempo estimado para que determinado evento ocorra. É definido como o inverso da probabilidade (GALVANI, 2005).

$$
T=1 / P=1 / f r(\text { f.05) }
$$

Onde: $T$ é o tempo de retorno, $P$ a probabilidade e $f r$ frequência relativa

Em 1992, a ONU, por meio do Programa das Nações Unidas para o Meio Ambiente (PNUMA), estabeleceu um Índice de Aridez (ÍA), aceito internacionalmente, que se expressa pelo quociente da divisão entre precipitação média anual dividida pela evapotranspiração potencial (f.06), com a seguinte gradação: valores superiores a 0,65 significariam ausência de aridez; entre 0,65 e 0,51, corresponderiam ao subúmido; 0,50-0,21 ao semi-árido; 0,20-0,05 ao árido e inferiores a 0,05 ao hiperárido.” (CONTI 2008, pags 43-44).

$$
I A=P / P E T(\text { f.06) }
$$

Onde: $I A$ é o índice de aridez, $P$ é a precipitação e $P E T$ é a evapotranspiração potencial

De acordo com Pacheco et al (2006), o governo brasileiro adotou um padrão de susceptibilidade à desertificação que varia entre áreas consideradas de alto, moderado e baixo riscos à desertificação, utilizando-se para esta classificação o Índice de Aridez Ía, como exposto na tabela 1. 
Tabela 1 Valores quantitativos e qualitativos para o Índice de Aridez e Susceptibilidade à Desertificação. Fonte: BARROS, 2010.

\begin{tabular}{l|l|l}
$\begin{array}{l}\text { Valores para a fórmula } \\
\text { P/PET }\end{array}$ & Classes climáticas & $\begin{array}{l}\text { Susceptibilidade à } \\
\text { desertificação }\end{array}$ \\
\hline $0,05<0,20$ & Árido & Muito alta \\
\hline $0,21<0,50$ & Semiárido & Alta \\
\hline $0,51<0,65$ & Subúmido Seco & Moderada \\
\hline$>0,65$ & Subúmido Úmido & Não susceptível
\end{tabular}

\section{Resultados e Discussão}

\section{Análise hidroclimatológica do estado do Rio Grande do Norte}

Para fins de identificar e localizar os eventos climáticos, trazemos o mapa das mesorregiões do estado do Rio Grande do Norte (Figura 1), que apesar de nesta delimitação, o IBGE não trazer apenas os aspectos físicos, mas sobretudo aspectos socioeconômicos, como segue "a divisão regional do Brasil em mesorregiões, partindo de determinações mais amplas a nível conjuntural, buscou identificar áreas individualizadas em cada uma das Unidades Federadas, tomadas como universo de análise e definiu as mesorregiões com base nas seguintes dimensões: o processo social como determinante, o quadro natural como condicionante e a rede de comunicação e de lugares como elemento da articulação espacial” (IBGE $2015 \mathrm{~s} / \mathrm{p}$ ), o mesmo se torna indispensável para a assimilação geográfica da análise climática que será feita a seguir. 


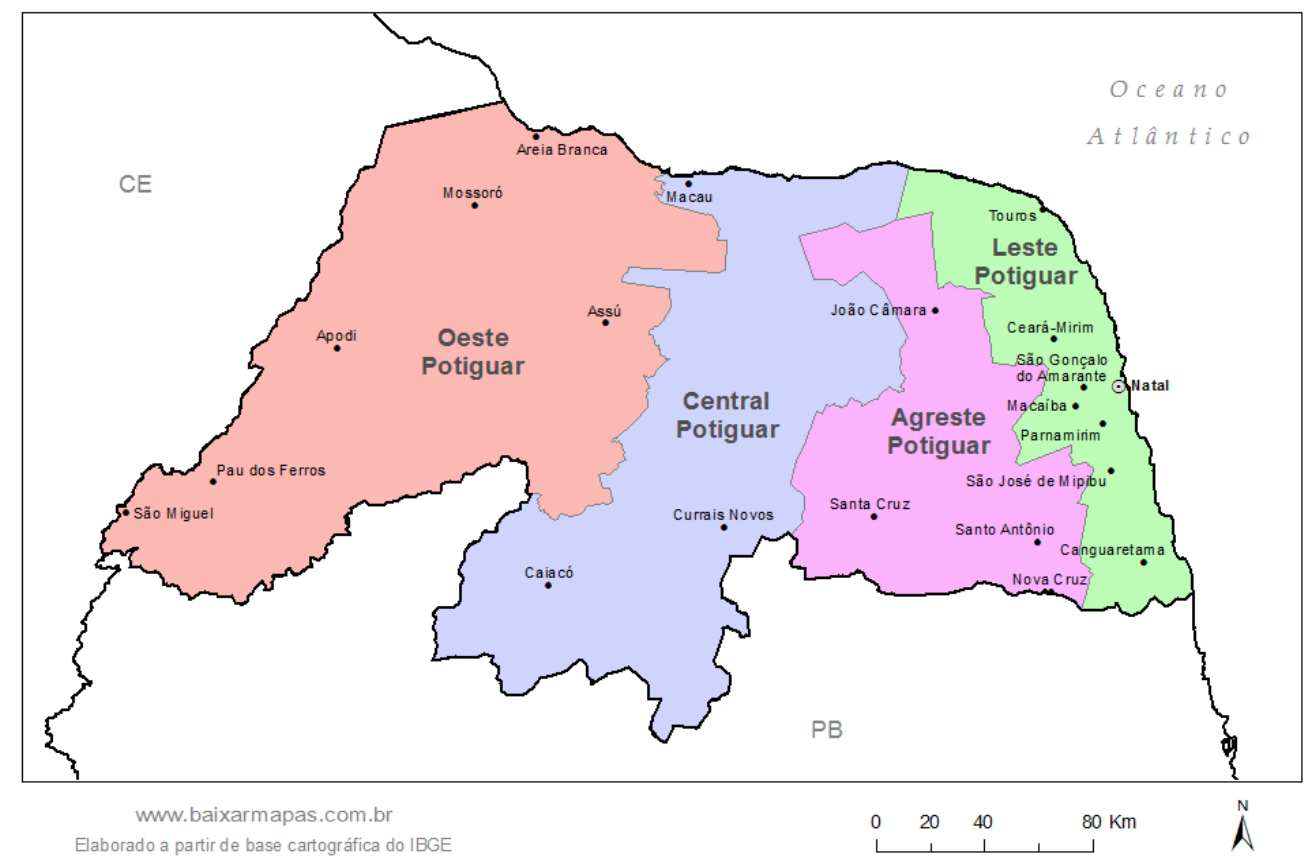

Figura 1 Mesorregiões Geográficas do estado do Rio Grande do Norte

Fonte: IBGE, 2015.

Analisando o comportamento das chuvas a partir do método dos quartis pode-se perceber que em um ano considerado "normal", $25 \%$ dos municípios do Rio Grande do Norte apresentam valores médios anuais inferiores aos 603,3 milímetros. Estes estão localizados na região central - leste do estado, abrangendo parte da mesorregião do Agreste Potiguar e da mesorregião Central Potiguar, como exposto na Figura 2, representados pela cor amarela. A mediana, ou seja 50\% dos municípios apresentaram chuvas anuais entre 603,3 e 870 milímetros, estão localizados em quase toda mesorregião do Oeste Potiguar, além de alguns pontos da região Central e também do Agreste Potiguar (cor verde). Por último, o terceiro quartil mostrou que $25 \%$ dos municípios apresentam valores superiores aos 870 milímetros de chuvas anuais, estes localizados no Litoral Leste, mesorregião Leste Potiguar e em poucos municípios do Agreste e Oeste potiguar. 


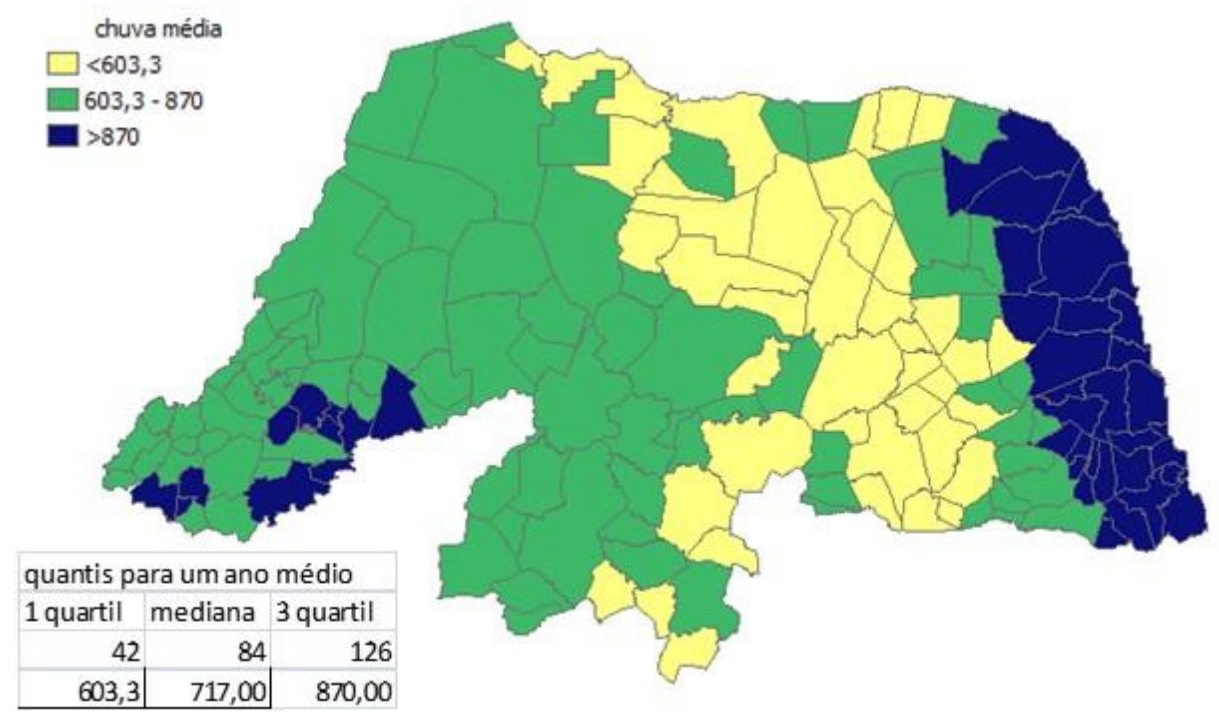

Figura 2 Distribuição da chuva em um ano "normal”, baseado na média climatológica (quartis). Fonte dos dados de chuva: EMATER

Para um ano considerado "chuvoso" 25\% dos municípios apresentaram precipitação anual inferior aos 941,9 milímetros, 50\% precipitações anuais entre 941,9 e 1300 milímetros e outros 25\% apresentaram precipitações anuais superiores aos 1300 milímetros. Quanto ao arranjo espacial, notase que, em um ano chuvoso, o litoral Leste apresenta maior homogeneidade, enquanto que as regiões do Agreste, Central e Oeste Potiguar tiveram um comportamento mais heterogêneo (Figura 3). A mesorregião Oeste de certo modo apresentou totais pluviométricos dentro da mediana, entre 941,9 e 1300, num ano chuvoso e ainda partes da região Central e Agreste apresentaram os totais mais baixos ( $1^{\mathrm{o}}$ quartil, em amarelo). 


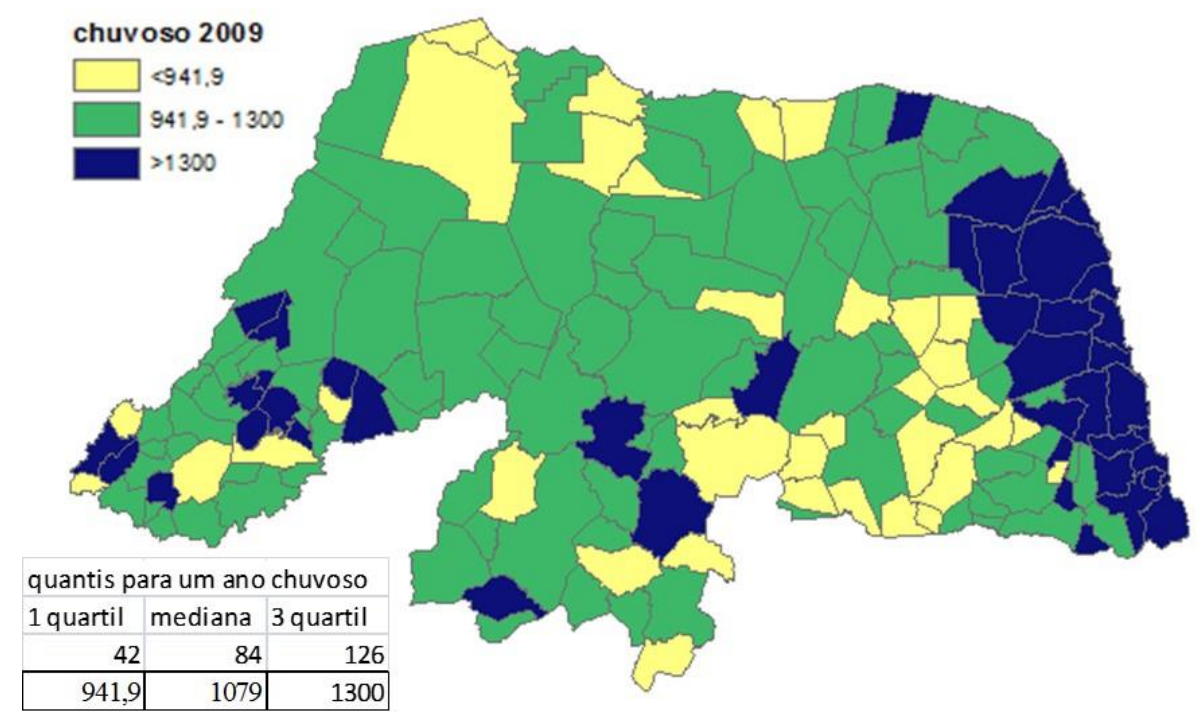

Figura 3 Distribuição da chuva em um ano "chuvoso" 2009, (quartis).

Analisando o comportamento das chuvas a partir do método dos quartis para um ano considerado "seco", observamos que 25\% dos municípios do Rio Grande do Norte apresentam valores anuais inferiores aos 349,5 milímetros. 50\% dos municípios apresentaram chuvas anuais entre 349,5 e 784,4 milímetros. O terceiro quartil mostrou que $25 \%$ dos municípios apresentam valores superiores aos 784,4 milímetros de chuvas anuais, estes localizados principalmente no litoral leste, e em alguns municípios do Oeste potiguar, principalmente em áreas serranas (Figura 4). Quanto à distribuição espacial dos totais de precipitação, percebe-se que o padrão espacial de um ano "seco" muito se assemelha ao padrão espacial de um ano "normal", exibindo nitidamente totais pluviométricos mais elevados no litoral leste, seguidos pelo Oeste potiguar e mostrando uma área mais seca na região central - leste, que inclui a mesorregião Central potiguar e poucos municípios do Agreste potiguar. 


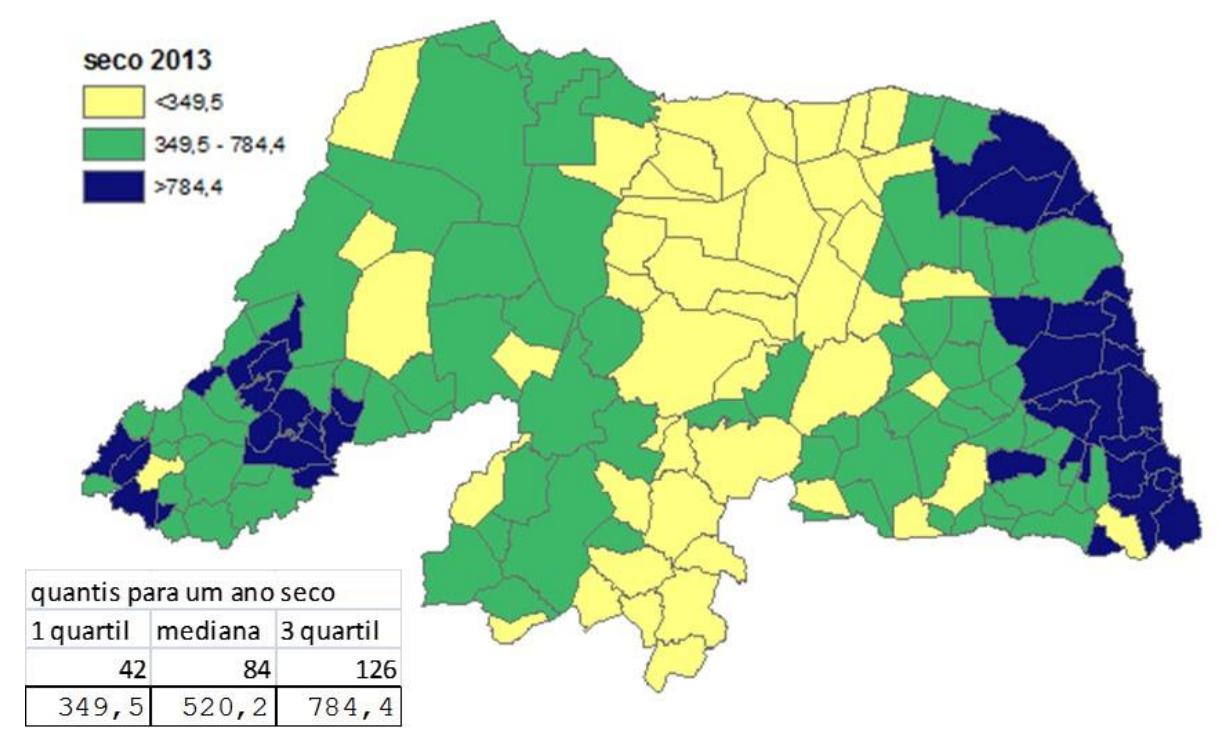

Figura 4 Distribuição da chuva em um ano "seco" 2013 (quartis).

Aplicando-se o Coeficiente de Redistribuição, obteve-se como resultado o valor de 0,18 , o que implica dizer que a chuva pouco se alterou sobre a estrutura espacial do estado do Rio Grande do Norte entre um ano chuvoso (2009) e seco (2013). Nota-se mais uma vez, que o Litoral Leste é detentor das maiores cotas pluviométricas, seguido pelo Oeste potiguar, e a Região Central e partes do Agreste possuidoras das menores cotas pluviométricas (ver Figura 5). 
$\square 366,700000-811,400000$

$\square 811,400001$ - 1031,600000

$1031,600001-1240,200000$

- 1240,200001 - 1570,200000

[ 1570,200001 - 2340,500000

$58,000000-294,500000$

$\square 294,500001-532,000000$

$\square 532,000001-803,400000$

$\square 03,400001$ - 1179,500000

- 1179,500001 - 1842,500000

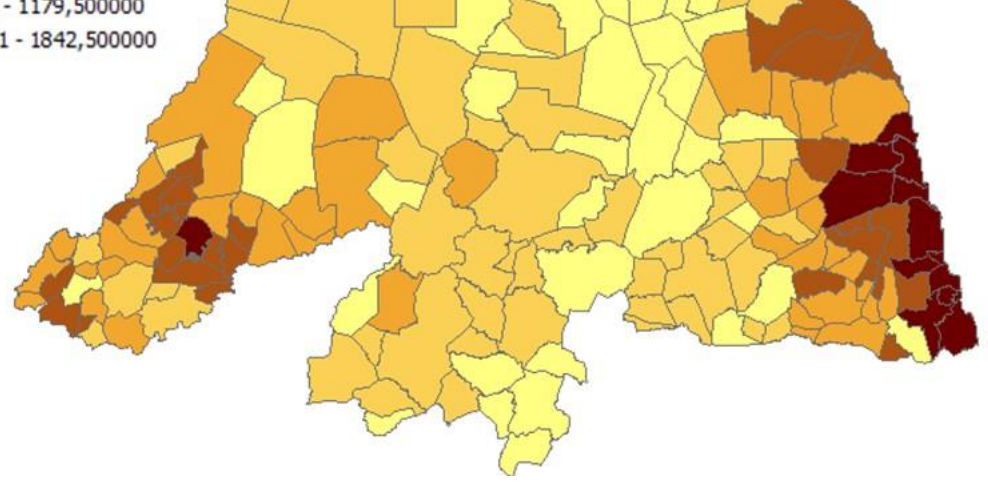

Figura 5 Total de chuva anual registrado no Rio Grande do Norte em uma ano chuvoso (2009) mapa azul e em um ano seco (2013) mapa em laranja e o resultado do coeficiente de redistribuição.

\section{Análise hidroclimatológica do município de Caicó/RN}

Primeiramente, para analisar a condição hidroclimatológica do município de Caicó foram selecionados dados de precipitação anual total entre 1911 e 2010 e elaborado um histograma com a distribuição de frequência das chuvas para cada intervalo de classe determinado. Percebe-se que houve predomínio de $28 \%$ dos anos estudados com precipitações na faixa de 471 a 653 milímetros anuais, que inclue a média, seguido pelo intervalo de 653 e 835 milímetros, com $21 \%$ do período com chuvas nessa faixa, como pode ser observado na Figura 6. O intervalo que abrange totais anuais entre 289 e $471 \mathrm{~mm}$ foi o terceiro maior, com 14\%, seguido pelo de 835 a $1017 \mathrm{~mm}$, com $13 \%$. 


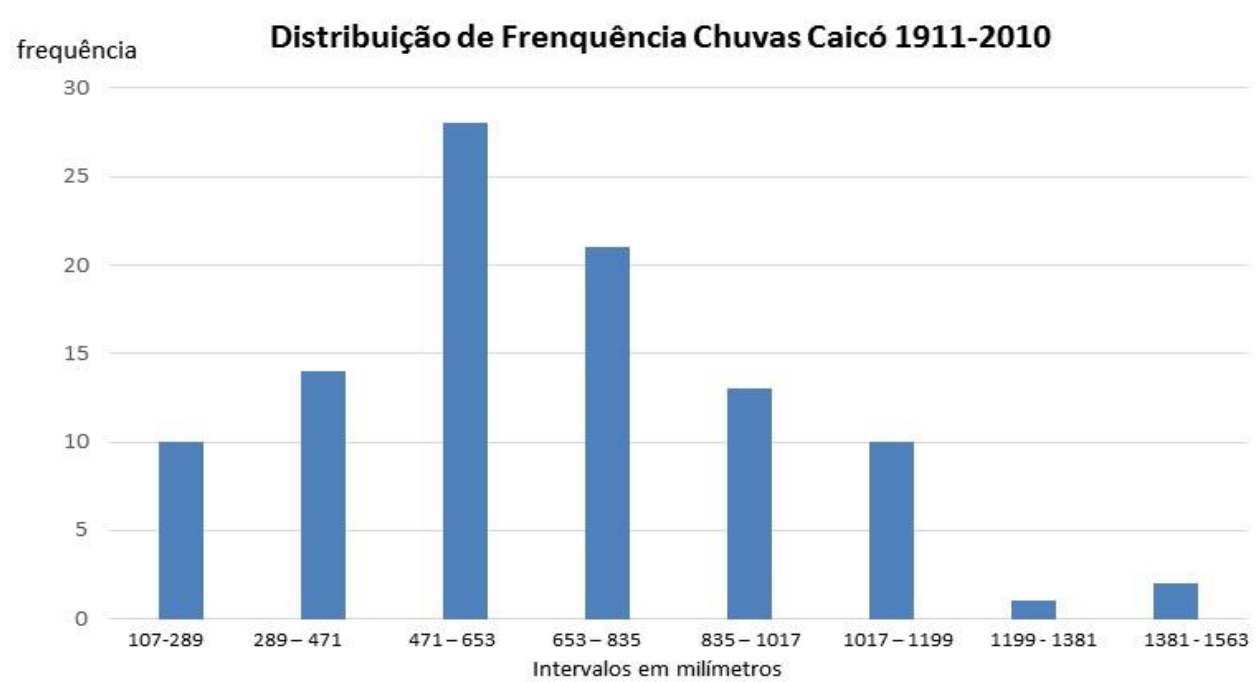

Figura 6 Histograma de distribuição de totais anuais de precipitação em Caicó (período 1911-2010).

Fonte: SUDENE/EMPARN/INMET

Analisando os dados de precipitação e evaporação do município de Caicó de 1996 a 2013, aplicando medidas de tendência central e de dispersão, chegou-se aos seguintes resultados: as médias de precipitação e evaporação anual foram de 638,1 e 3098,3, milímetros respectivamente. Tais valores mostram que, em média, anualmente a quantidade de água evaporada é 5 vezes maior que a quantidade de água precipitada em Caicó. Esta informação, por si só, mostra que existe um déficit de água na superfície que pode gerar problemas com relação à demanda natural e socioeconômica (LUCENA \& STEINKE, 2014), (Tabela 2).

Tabela 2 Valores médios anuais de medidas de tendência central e de dispersão para o município de Caicó (período de 1996 - 2013).

\begin{tabular}{l|l|l}
$\underline{\underline{\text { Caicó} / \mathbf{R N}}} \underline{\underline{\text { Período 1996- 2013) }}}$ & $\begin{array}{l}\underline{\text { Precipitação }} \\
\mathbf{( \mathbf { m m } )}\end{array}$ & $\begin{array}{l}\underline{\text { Evaporacão }} \\
\mathbf{( \mathbf { m m } )}\end{array}$ \\
\hline Média Aritmética & 638,1 & 3098,3 \\
\hline Valor Máximo & 1191,2 & 3655,3 \\
\hline Valor Mínimo & 174,6 & 2630,9 \\
\hline Amplitude Total & 1016,6 & 1024,4 \\
\hline Desvio Padrão da População & 274,6 & 280 \\
\hline Coeficiente de Variação & $43 \%$ & $9 \%$
\end{tabular}

Fonte: LUCENA \& STEINKE, 2014. 
Os valores Máximo e Mínimo expressam simplesmente o maior e menor valor da população (série de dados), indicando a amplitude. A Amplitude total é a diferença entre o V. Max e o V. Min do conjunto de dados. Quanto maior for a amplitude total, maior é a variabilidade dos valores (REBOITA, 2005). Para a precipitação e evaporação no município de Caicó os V. Max e V.Min foram: 1191,2 e 174,6mm e 3655,3 e 2630,9mm respectivamente. Em Caicó as Amplitudes Totais para precipitação e evaporação foram de 1016,6mm e 1024,4mm, respectivamente. Os valores de amplitude total das duas variáveis foram muito semelhantes, no entanto, convém lembrar que os V Max e V. Min são bem distintos para as duas variáveis, o que nos mostra que mesmo com amplitude semelhante, a variável evaporação predomina sobre a precipitação.

Para precipitação e evaporação os valores do Desvio Padrão foram de 274,6 e 280, respectivamente. Estes valores foram bem próximos, mas o Coeficiente de Variação, por sua vez mostra que na realidade não é tão parecido assim. Apesar dos dados de precipitação e evaporação de Caicó com relação ao Desvio Padrão terem sido bem semelhantes (ver tabela 2), o CV mostrou que os dados de chuva apresentaram uma maior heterogeneidade do que os dados de evaporação. Esta variabilidade foi quase 5 vezes maior para precipitação, com CV de $43 \%$ e de $9 \%$ para evaporação (ver tabela 2). Este resultado é muito importante, pois mostra que além da chuva ser inferior à evaporação em termos de quantidade, ela também é mais variável no tempo (LUCENA \& STEINKE, 2014).

Os conjuntos de dados de precipitação e evaporação foram agrupados em cinco intervalos de classes e os resultados mostraram que para precipitação, existe uma maior probabilidade de ocorrência (28\%) de precipitações entre 581 e $784 \mathrm{~mm}$, ou seja, para os valores mais próximos à média. Por outro lado há uma menor probabilidade (11\%) para eventos de chuva em que o total anual esteja entre 987 e 1191 milímetros. Para os dados de evaporação os resultados foram os seguintes: maior probabilidade (28\%) da evaporação anual para valores entre 3245 e 3450 milímetros, e menor probabilidade (11\%) para valores de 3451 a 2655 milímetros. Para os valores de evaporação, há uma maior probabilidade de ocorrência para valores que se encontram 1 classe acima da que está a média, o que significa que a evaporação tende a ser maior que a média, agravando ainda mais a situação hídrica local.

O tempo de retorno ou de recorrência, que é o intervalo de tempo (geralmente em anos) estimado de ocorrência de um determinado evento, definido assim como o inverso da probabilidade, foi de 3,7 anos para os valores de precipitação próximos da média, entre 581,26-784,58 e de 9 anos para precipitações superiores aos 900 milímetros. Logo, o tempo de retorno para que ocorra uma chuva 
superior a 900 milímetros, valor de um ano considerado "chuvoso" em Caicó, é de aproximadamente 9 anos. A tabela 3 apresenta o tempo de retorno para taxas de precipitação e evaporação para o município de Caicó/RN.

Tabela 3 Tempo de retorno em anos para precipitação e evaporação dispostos em classes (período de 1996 - 2013).

\begin{tabular}{l|c|c|c}
\multicolumn{2}{c|}{ Precipitação } & \multicolumn{2}{c}{ Evaporação } \\
\hline Inter. de classe & $\begin{array}{l}\text { Tempo de } \\
\text { Retorno }\end{array}$ & Inter. de classe & $\begin{array}{l}\text { Tempo de } \\
\text { Retorno }\end{array}$ \\
\hline $174,6-377,92$ & 4,5 & $2630,9-2835,78$ & 4,5 \\
\hline $377,93-581,25$ & 6,2 & $2835,79-3040,67$ & 6,2 \\
\hline $581,26-784,58$ & 3,7 & $3040,68-3245,56$ & 4,5 \\
\hline $784,60-987,91$ & 4,5 & $3245,57-3450,45$ & 3,7 \\
\hline $987,92-1191,24$ & 9,0 & $3450,46-3655,34$ & 9,0
\end{tabular}

Fonte: LUCENA \& STEINKE, 2014

\section{Índice de Aridez}

Para distinguir as diferentes regiões do globo de acordo com os tipos climáticos, foram e vêm sendo elaborados vários modelos de classificação climática. A depender do propósito, estes modelos se utilizam de diferentes variáveis meteorológicas. Algumas classificações levam em consideração as massas de ar e ventos, outras o balanço de radiação, outras ainda o grau de umidade. (TORRES; MACHADO, 2011). O Índice de Aridez nada mais é que uma classificação climática que enfoca a disponibilidade hídrica de uma região assim como pode inferir a susceptibilidade ao processo de desertificação, como descrito adiante.

Para Caicó aplicou-se o Índice de Aridez (IA) por ano e a média para todos os anos. A série considerada foi de 10 anos por faltarem dados de evapotranspiração potencial anteriores ao ano de 2003 (Tabela 4). Na tabela 4, os resultados mostraram que a média do IA para o município foi de 0,41, classificando o clima de Caicó como semiárido. Na série analisada foram registrados 1 ano sem aridez e 1 ano árido, com taxas de 0,68 e 0,11 respectivamente. 
Tabela 4 Índice de Aridez e Susceptibilidade à Desertificação para o município de CaicóRN para os dez últimos anos (período 2003 - 2013).

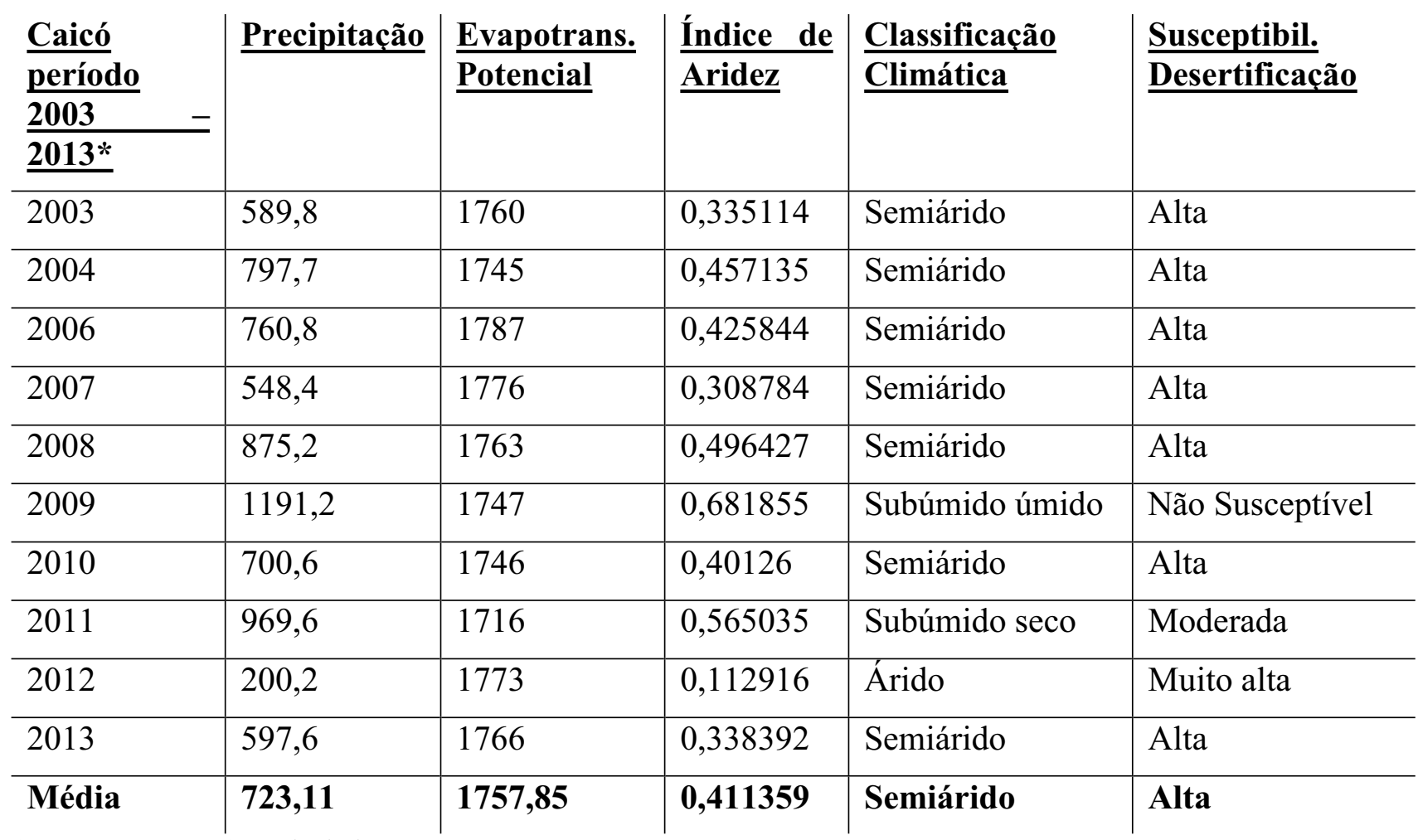

*exceto 2005 por falta de dados

Fonte: LUCENA \& STEINKE, 2014.

Quanto a susceptibilidade à desertificação, os resultados mostraram que Caicó está altamente susceptível a este processo, se levarmos em conta as condições climáticas atuantes, obtendo um valor médio de 0,41 no índice de Aridez, como pode ser visto na Tabela 4 e na Figura 7. 


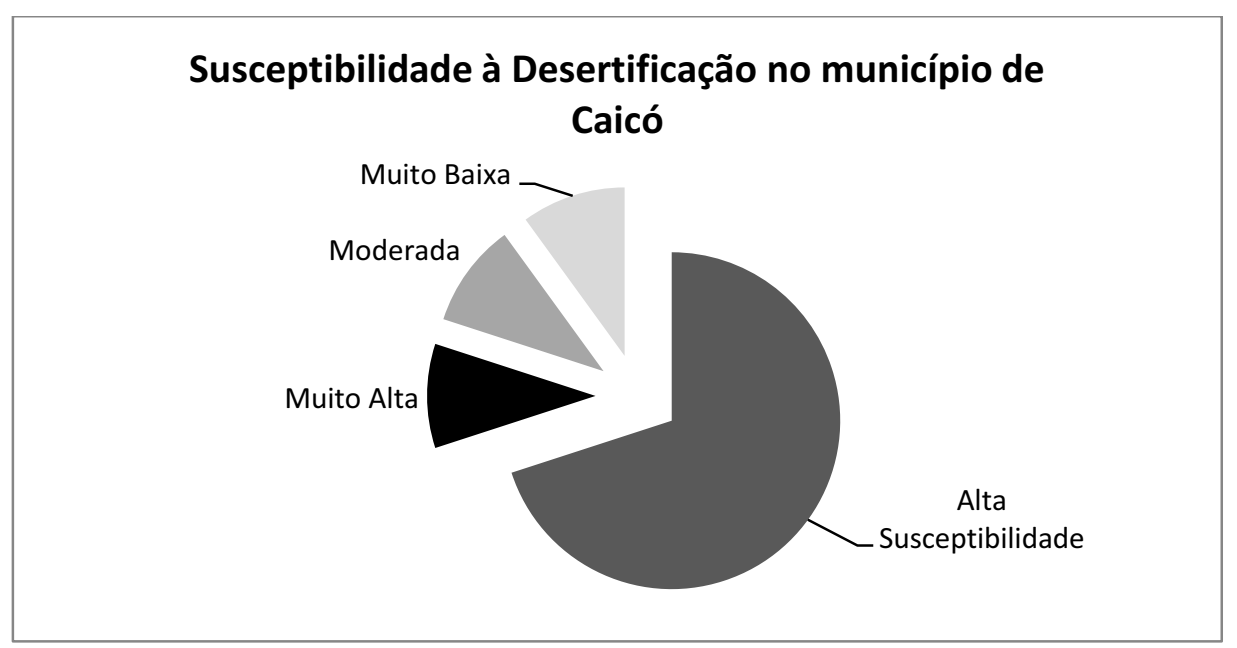

Figura 7 Gráfico de pizza mostrando a proporção de anos susceptíveis à desertificação no município de Caicó para o período de 2003 à 2013.

Fonte: dados da pesquisa.

Tais resultados só confirmam a vulnerabilidade a que está submetido o município de Caicó, com relação à falta de água, numa perspectiva de crescimento urbano para os próximos anos. Medidas eficazes para armazenar a água e proteger a vegetação Caatinga devem ser tratadas com prioridade pelo governo e sociedade.

\section{Considerações Finais}

A partir dos resultados obtidos pôde-se observar que o estado do Rio Grande do Norte possui, de um modo geral, precipitações relativamente baixas, visto que 75\% dos municípios apresentam precipitações médias anuais inferiores aos $871 \mathrm{~mm}$.

Por meio do método dos quartis, observou-se que em um ano considerado chuvoso, $75 \%$ dos municípios apresentaram precipitação superior aos $941,9 \mathrm{~mm}$, sendo que $25 \%$ apresentou totais anuais superiores aos $1300 \mathrm{~mm}$, estes localizados principalmente no litoral leste do RN. Para um ano seco, $75 \%$ dos municípios apresentaram precipitações inferiores aos $784,4 \mathrm{~mm}$, sendo que o primeiro quartil, que corresponde a $25 \%$ dos municípios, apresentou precipitações inferiores aos $349,5 \mathrm{~mm}$, estando estes concentrados, sobretudo, na mesorregião Central potiguar. Tanto em anos considerados normais, assim como em anos chuvosos e secos, a distribuição espacial das chuvas mostrou pouca alteração, como confirmado pelo Coeficiente de Redistribuição com resultado de 0,18, com os maiores totais pluviométricos no litoral leste (mesorregião Leste potiguar), assim como em algumas áreas serranas 
do extremo oeste do estado (mesorregião Oeste potiguar). A região mais seca do RN abarca a parte central - leste do estado chegando até o litoral Norte (mesorregião Central potiguar) e partes do Agreste potiguar.

O município de Caicó, localizado na mesorregião Central potiguar, apresentou, no período de cem anos, maior frequência de chuvas entre $471 \mathrm{~mm}$ e $653 \mathrm{~mm}$ anuais. Viu-se também que a evaporação supera em muito a precipitação, numa média anual de 5 vezes mais. Mesmo no ano mais chuvoso da série analisada (2009), a evaporação foi pelo menos 3 vezes maior que a precipitação. O Coeficiente de Variação mostrou que a chuva apresentou uma maior variabilidade interanual que a evaporação, sendo o CV de 43\%, para chuva e de 9\% para a evaporação. Este resultado é muito importante, pois mostra que, além da chuva ter sido inferior à evaporação em termos de quantidade, ela também é mais variável no tempo.Quanto à probabilidade, o intervalo de classe de chuva que contém a média é o que apresenta maior possibilidade de ocorrência enquanto os melhores índices de chuva, que seriam superiores aos $900 \mathrm{~mm}$, apresentaram a menor probabilidade de ocorrência. Já o tempo de recorrência de um evento anual de chuva foi menor para os valores de precipitação próximos da média, entre 581,26-784,58 ( 3,7 anos) e maior para precipitações superiores aos 900 milímetros (9 anos).

Os resultados da aplicação do Índice de Aridez mostraram que o município de Caicó se enquadra na condição de clima "semiárido" com "alta susceptibilidade climática à desertificação". Tais resultados só confirmam a vulnerabilidade a que está submetido o município de Caicó com relação à falta de água, numa perspectiva de crescimento populacional para os próximos anos.

Muitos municípios do estado do Rio Grande do Norte, principalmente aqueles localizados na mesorregião Central potiguar, apresentam características climáticas semelhantes e até mais hostis que o município de Caicó, com baixas taxas de precipitação e forte variabilidade temporal e espacial das mesmas. Assim sendo, medidas eficazes para armazenar a água e proteger a vegetação Caatinga devem ser tratadas com prioridade pelo governo e sociedade. Métodos que armazenem a água e que evitem sua perda por evaporação como construção de barragens subterrâneas, cisternas, construção de reservatórios profundos (em relevo adequado) e a dragagem dos reservatórios já existentes, podem diminuir a perda de água por evaporação. Medidas de proteção do solo são também tão relevantes quanto as de armazenamento de água. A construção de renques e barramentos ajuda a segurar os solos e também o conteúdo de umidade presentes neles, favorecendo o melhor desenvolvimento da vegetação Caatinga e consequentemente maior retenção de água no sistema, sendo estas medidas que devem ser colocadas como a ordem do dia no estado do Rio Grande do Norte. 


\section{Bibliografia}

AB'SABER, A. N. Caatingas: O domínio dos sertões secos. In: Os domínios de natureza no Brasil: potencialidades paisagísticas. $1^{\mathrm{a}}$ ed. São Paulo: Ateliê Editorial, 2003.

BARROS, $\mathrm{K}$ de $\mathrm{O}$. Índice de aridez como indicador da susceptibilidade à desertificação na mesorregião norte de Minas. Monografia (Geografia). Universidade Federal de Viçosa, Minas Gerais, 2010. 89p.

CALASANS, N. A. R.; LEVY, M, do C. T.; MOREAU, M. Interrelações entre clima e vazão. In: Schiavetti, A. \& Camargo, A. F. M. Conceitos de Bacias hidrográficas: teorias e aplicações. Ilhéus/BA: Editus, 2008.

CONTI, J. B. O conceito de Desertificação. CLIMEP - Climatologia e Estudos da Paisagem. Rio Claro, vol.3, n.2, p. 39-52, jul./dez. 2008.

DREW, D. Água. In: DREW, D. Processos interativos homem - meio ambiente. $6^{\mathrm{a}}$ ed. - Rio de Janeiro: Bertrand Brasil, 2005. 206p.

EMPARN - Empresa de Pesquisa Agropecuária do RN - EMPARN Gerência de Meteorologia. Climatologia Rio Grande do Norte. Disponível em:

$<$ http://189.124.201.150/climaRN/medias historicas municipios RN.htm>, Acesso em: 10/10/2014.

FRANCISCO, W. de. Estatística básica: síntese da teoria, exercícios propostos e resolvidos. $2^{\mathrm{a}}$ Ed. Piracicaba: Editora Unimep, 1995.

GALVANI, E. Métodos e técnicas de quantificação em Geografia. In: VENTURI, L. A. B (Org). Praticando Geografia: Técnicas de Campo e Laboratório. 1a. ed. São Paulo: Oficina de Textos, 2005. v. 1. 239 p.

IBGE 2015. Divisão regional. Disponível em:

$<$ http://www.ibge.gov.br/home/geociencias/geografia/default div int.shtm?c=1 $>$, Acesso em $08 / 11 / 2015$.

INMET. (2014). Instituto Nacional de Meteorologia. BDMET. Disponível em:

$<$ http://www.inmet.gov.br/portal/index.php?r=bdmep/bdmep >. Acesso em 20/12/2015.

LUCENA, J. A. SOUZA, B. I, MOURA, M. de O., LIMA, J. de O. análise da variabilidade da precipitação pluviométrica como subsídio para o planejamento agrícola em Caicó/RN. Revista brasileira de Climatologia. Ano 8 - Vol. 10 - Jan/Jun 2012. 121 - 135p.

LUCENA, R. L.; STEINKE, E. T.. Diagnóstico climático para o município de Caicó/RN com ênfase à disponibilidade de água no sistema-superfície-atmosfera. Anais.. In: X Simpósio Brasileiro de Climatologia Geográfica, 2014, Curitiba. Anais do X Simpósio Brasileiro de Climatologia Geográfica. Curitiba: ABClima, 2014. p. 1577-1587. 
MMA - Ministério do Meio Ambiente. SANTANA, M. O (Org). Atlas das áreas susceptíveis à desertificação do Brasil. Brasília: Ed: MMA - Ministério do Meio Ambiente, 2007.

OLIVEIRA, J. C. F. de (Org). Atmosfera e sociedade: a ação da atmosfera sobre os seres vivos e a qualidade de vida humana. Vol. 1. Maceió: EDUFAL, 2010.

PACHECO, A. da P.; FREIRE, N. C. F.; BORGES, U. da N. A transdisciplinaridade da Desertificação. Geografia (Londrina), v 15, n. 1, p, 5 - 34, jan./jun, 2006.

REBOITA, M. S. Introdução à Estatística Aplicada à Climatologia: Parte I Estatística Descritiva. Projeto PAE. São Paulo, 2005.

REBOUÇAS, A. de C. (Org). Águas doces no Brasil: capital ecológico, uso e conservação. São Paulo: Escrituras Editora, 2002. 703p.

REIS, Marcelo Menezes. Quartis. Disponível em:

$<$ http://www.inf.ufsc.br/ marcelo.menezes.reis/AED05.pdf $>$, Acesso em 12/12/2015.

SOUZA, Carolina Carvalho Garcia de.; ALVES, Lucir Reinaldo. A especialização e a reestruturação produtiva das atividades econômicas entre as mesorregiões do Brasil entre 2000 a 2009. Informe Gepec, Toledo, v. 15, número especial, p. 145-161, 2011.

SUDENE - Superintendência de Desenvolvimento do Nordeste. Região Nordeste. Disponível em: $<$ http://www.sudene.gov.br/acesso-a-informacao/institucional/area-de-atuacao-da-sudene/regiaonordeste $>$ Acesso em 09/03/2015.

TORRES, F. T. P.; MACHADO, P. J. de O. Introdução à Climatologia. São Paulo: Cengage Learning, 2011.

TRIOLA, M. F. Introdução à Estatística. 7ª Ed. Rio de Janeiro: LTC, 1998.

TUCCI, C. E. M. Hidrologia: Ciência e Aplicação. 3. ed. Porto Alegre: Ed. Da Universidade, 2002. 
2.2 Artigo 2 Variabilidade climática no município de Caicó/RN: secas e chuvas num arquétipo do clima semiárido do Nordeste brasileiro.

Autoria: Rebecca Luna Lucena; Almir M. Ferreira; Hítalo F. P. de A. Ferreira; Ercília Torres Steinke

\title{
Resumo
}

As condições instáveis do clima semiárido brasileiro se revelam no município de Caicó/RN através de períodos secos e chuvosos que se alternam continuamente. Logo, torna-se imprescindível analisar o comportamento das precipitações em Caicó com vistas ao planejamento urbano e rural. Para tanto, dados brutos de precipitação foram coletados e compilados, normais climatológicas foram elaboradas, a tendência foi analisada por meio de regressão linear e para definição de períodos secos, foram elaborados gráficos ombrotérmicos. Os resultados mostraram que a variação interanual das chuvas foi acentuada em Caicó/RN. Os gráficos ombrotérmicos revelaram que houve predomínio de meses secos no decorrer de um ano. Quanto à tendência, verificou-se que se trata de uma série estacionária, não havendo aumento ou diminuição significativa das chuvas na série histórica analisada. Por último, concluiu-se que a instabilidade pluviométrica é condição inerente ao clima de Caicó e que ações de armazenamento e distribuição adequadas da água deve ser prioridade no planejamento municipal.

Palavras-chave: Semiárido Brasileiro. Variabilidade Climática. Precipitações. Caicó-RN.

\begin{abstract}
Unstable conditions of Brazil's semiarid climate reveal themselves in the Caicó city (State of Rio Grande do Norte - RN) through dry and rainy periods that continuously alternate. Therefore, it is very important to study Caicó's precipitation behavior, aiming at rural and urban planning. In order to achieve that, raw precipitation data were collected and compiled, climate normals were calculated, the tendency was analyzed by linear regression and ombrothermic diagrams were elaborated to define dry periods. The results showed that interannual rain variation was accentuated in Caicó. The ombrothermic diagrams revealed that dry months prevailed during the year. Regarding the tendency, it was verified that it was a stationary series, there was no significant increase or decrease in rainfall in the historical series analyzed. Finally, the conclusion was that the pluviometric instability was an inherent condition in Caicó's climate and the actions of water's storage and appropriate distribution must be priority items in municipal planning.
\end{abstract}

Keywords: Brazilian Semiarid Region. Climatic Variability. Precipitation. Caicó (State of Rio Grande do Norte - RN).

\section{Resumen}

Las condiciones inestables del clima semiárido brasileño se revelan en el municipio de Caicó/RN en épocas secas y lluviosas que se alternan continuamente. Sin embargo, es esencial analizar el 
comportamiento de las precipitaciones en Caicó con vistas a la planificación urbana y rural. Para ello, se recogieron y compilaron datos de precipitaciones, se prepararon las normales climatológicas, la tendencia se analizó mediante regresión lineal y la definición de los períodos de sequía a través de gráficas ombrotérmicos. Los resultados mostraron que la variación interanual de la precipitación se acentuó en Caicó/RN. LA gráfica ombrotérmicos reveló que hubo un predominio de meses de sequía en el período de un año. Cuanto a la tendencia, fue encontrado que esta es una serie estacionaria, sin aumento o disminución significativa de las precipitaciones en la serie de tiempo analizada. Por último, se ha concluido que la inestabilidad de las lluvias es una condición inherente al clima de Caico y que acciones apropiadas de almacenamiento y distribución de agua deben ser una prioridad en la planificación municipal.

Palabras-clave: Región Semiárida Brasileña. Variabilidad del Clima. Precipitación. Caicó-RN.

\section{Introdução}

A complexidade climática da região semiárida do Nordeste do Brasil, com relação às secas e às chuvas, é produto de múltiplos fatores geográficos associados à atuação de vários sistemas atmosféricos que operam, muitas vezes, de modo desigual e imprevisível. Eles são responsáveis por períodos mais secos ou chuvosos que se alternam continuamente. Os períodos secos são aqueles que mais afetam todos os tipos de vida. Por esta razão, é comum o estudo climático apurado de regiões sujeitas a períodos de estiagem prolongada.

As chuvas se configuram como um fenômeno importantíssimo para as sociedades uma vez que dependemos da água para o nosso desenvolvimento em todos os seus níveis (AYOADE, 2007). Além da água ser um elemento essencial à vida, ela atua diretamente no desenvolvimento econômico a partir, por exemplo, da geração de energia elétrica em hidroelétricas. A importância da água pode ser exemplificada na agricultura e na pecuária, que necessitam desse recurso, em diferentes proporções. A água além se de ser “insumo básico da sobrevivência de todas as espécies é indicador do desenvolvimento de uma região, sendo necessária atenção especial no seu manejo visando sua conservação em qualidade e quantidade" (VASCONCELOS; SILANS, 2011, p. 4). O manejo adequado da água é obtido por meio de ações de planejamento e gestão que visam quantificar e resolver as questões que envolvem os recursos hídricos com fins de otimizar os usos múltiplos (SETTI Et al., 2001). Por isso, nas regiões semiáridas do globo, como o município de Caicó localizado no semiárido brasileiro, é imprescindível analisar o comportamento das chuvas, juntamente com os sistemas atmosféricos atuantes, no sentido de gerar indicadores climáticos. 
O município de Caicó, localizado na microrregião do Seridó no Rio Grande do Norte, está inserido no Nordeste brasileiro (Figura 01), numa zona de baixa latitude, próximo à linha do Equador.

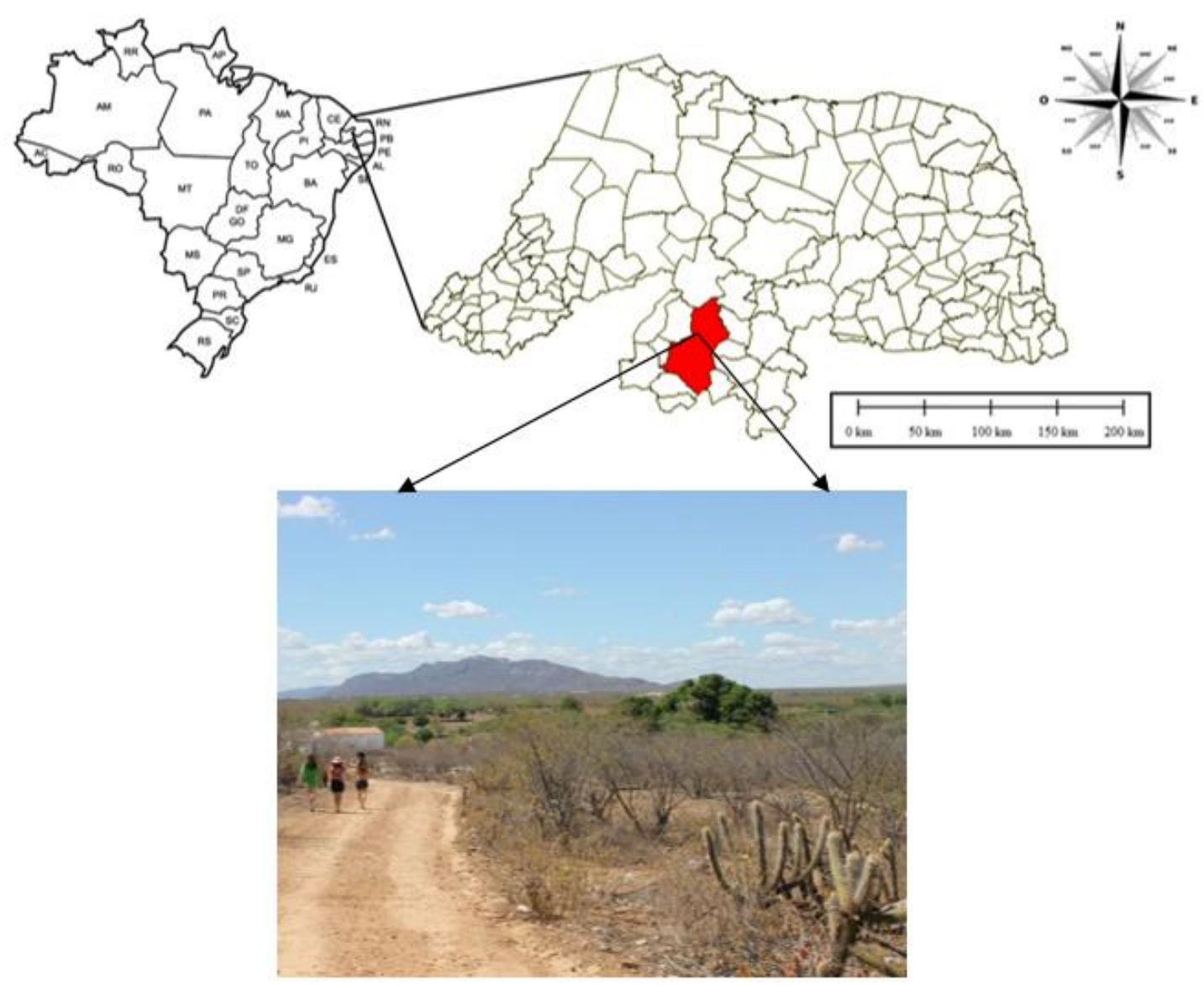

Figura 1 Município de Caicó, na perspectiva do Brasil e a paisagem típica de sua zona rural, situada no domínio da Caatinga do Sertão do Seridó.

Fonte: Monteiro (2012), com modificações.

Caicó é o município mais importante da microrregião do Seridó Ocidental e um dos mais importantes de toda a região do Seridó norte-rio-grandense e paraibano devido ao forte desenvolvimento das atividades comerciais, da pecuária, dos grandes eventos festivos, do número de estabelecimentos de ensino etc. Com uma população de 62.709 habitantes no ano de 2010 (IBGE, 2013), Caicó é um município que apresenta um bom Índice de Desenvolvimento Humano - IDH com 0,710 , enquanto grande parte dos municípios do semiárido nordestino apresentam IDH menor que 0,600 (PNUD, 2013). 
Está sob a influência do clima do tipo semiárido, típico do interior do Nordeste brasileiro. Na classificação de Koppen, este município possui clima do tipo BSwh. Nesse domínio climático há, segundo Ab'Saber (2003), um ritmo desigual e pouco freqüente das precipitações com fortes deficiências hídricas anuais, irregularidades no volume global de precipitações de ano para ano, com eventuais anos secos. As temperaturas máximas, médias e mínimas são altas durante o ano todo, ficando em torno de $26^{\circ} \mathrm{C}$. As taxas de insolação e de evaporação são sempre elevadas e, associadas ao terreno cristalino, não propiciam a acumulação de água favorecendo a situação de semiaridez (BRANCO, 2003).

O relevo da área é representado em sua grande parte por terrenos baixos da Depressão Sertaneja, apresentando um aspecto plano-ondulado e cotas altimétricas variando de 150 a 300 metros (COSTA, 2006). Tal condição, associada à localização latitudinal do município, gera altos índices de temperatura do ar. Os solos rasos e pedregosos favorecem o desenvolvimento da vegetação do tipo Caatinga, rica em arbustos e árvores baixas, além de várias espécies xerófitas. Nesse tipo de vegetação as espécies “mais representativas são a jurema preta, marmeleiro, pau-branco, xique-xique, juazeiro, pereiro, mandacaru, catingueira, aroreira, angico e imburana.” (IDEMA, 2005, p; 17). A figura 01 mostra um exemplo típico do tipo de vegetação predominante no município de Caicó.

As condições naturais de semiaridez logo aparecem como um ponto chave numa perspectiva de crescimento municipal, principalmente com relação à questão da água. Neste sentido, este artigo teve como objetivo principal analisar o comportamento anual e interanual das precipitações no município de Caicó/RN, no intuito de se compreender o ritmo prevalecente da atmosfera com vistas ao planejamento urbano e rural.

\section{Procedimentos Metodológicos}

Os procedimentos metodológicos utilizados neste artigo têm sido realizados nos atuais estudos de climatologia, referentes à análise do comportamento das precipitações.

De início, foi realizada a pesquisa bibliográfica que se pautou em títulos sobre os sistemas atmosféricos atuantes na região semiárida e na leitura e interpretação de imagens de satélite meteorológico Meteosat (IR) para identificação dos principais sistemas atmosféricos atuantes em anos normais, chuvosos e secos na região. 
Os dados brutos de precipitação foram obtidos de pluviômetros provenientes da Superintendência de Desenvolvimento do Nordeste - SUDENE (1990)/EMATER e do Instituto Nacional de Meteorologia - INMET, na estação climatológica do Seridó (Caicó/UFRN), registrados em milímetros ( $\mathrm{mm}$ ) de chuva. Esses dados foram tabulados e compilados, e a série selecionada para análise interanual das chuvas em Caicó, com elaboração de normais climatológicas, linha de tendência, e identificação de eventos intensos de El Niño e La Niña foi de um século (1911 - 2010).

Para análise anual e mensal de precipitação e para a elaboração de gráficos ombrotérmicos, a série selecionada foi de 15 anos (1995 - 2010). Para isso, definimos um ano normal, seco e chuvoso seguindo a metodologia proposta por Sant'anna Neto (1990).

Para início da análise das precipitações foram elaboradas Normais Climatológicas. "A Organização Mundial de Meteorologia (OMM) define normais como médias computadas para um período relativamente longo e uniforme, compreendendo pelo menos três períodos consecutivos de dez anos" (OLIVEIRA; VECCHIA, 2010 p.01). Obtém-se as normais por meio de médias aritméticas. De acordo com Galvani (2005) e Rebiota (2005), este é o procedimento mais simples e comum passível de ser aplicado a um conjunto de dados. Esta medida de tendência central expressa o somatório de todos os elementos da série dividido pelo número total de elementos, como descrito na fórmula 01 :

$$
\bar{x}=\frac{x_{1}+x_{2}+\ldots .+x_{n}}{n}=\frac{1}{n} \sum_{i=1}^{n} x_{i}
$$

Onde $\overline{\mathrm{x}}$ é o somatório de todos os elementos da série $x_{1}, x_{2}, x_{3} \ldots$ dividido pelo número de elementos $n$.

As normais climatológicas foram divididas da seguinte forma: como no Brasil o período padronizado das normais climatológicas refere-se aos anos de 1931-1960 e 1961-1990, seguimos esse período dividindo então a série temporal em quatro normais, sendo 2 normais completas e 2 "meias normais" ou mesmo "1 meia normal e uma normal provisória". No caso de não existir 30 anos seguidos de dados, as normais provisórias podem ser calculadas "em médias de curto prazo com base em observações que se prolonguem por um período de pelo menos dez anos" (OLIVEIRA; VECCHIA, 2010, p.01). 
Para identificar a quantidade de meses secos no ano, foram elaborados gráficos ombrotérmicos seguindo a metodologia de Gaussen e Bagnouls. A série temporal para esta análise só contemplou 15 anos por incluir a variável temperatura, que em Caicó não possui um tempo maior de registro.

Gaussen, entre outros, propõe um índice de aridez e um gráfico, denominado diagrama ombrotérmico, que relaciona as precipitações e as temperaturas. Baseados nesse índice, Gaussen e Bagnouls organizaram uma classificação empírica com propósito biológico em âmbito mundial... O período seco é aquele em que P é menor ou igual a 2T, ambas médias mensais (fórmula 02) (TORRES; MACHADO, 2011, pag 142-143).

$$
\mathrm{P} \leq 2 \mathrm{~T} \quad \mathrm{f} .02
$$

onde $P$ representa a precipitação e $T$ temperatura.

Aplicando-se a fórmula anterior, obtém-se o índice de aridez ou índice xerotérmico de Gaussen, com o qual se traça um gráfico conhecido como curva ombrométrica (MENDONÇA; DANNIOLIVEIRA, 2007). Os meses em que a coluna das precipitações estiver sob a curva térmica são considerados secos (período biologicamente seco) (TORRES; MACHADO, 2011). Com isso, procurou-se registrar os períodos considerados favoráveis ou desfavoráveis à vegetação, como os períodos secos e os períodos úmidos. Este índice permite diferenciar regiões bioclimáticas (Nimer Et al., 2013).

Para analisar a tendência da série secular de precipitação em Caicó, foi elaborada a linha de tendência por meio do modelo de regressão linear. Essa linha revela se há tendência e possibilita a realização de projeções. Uma linha de tendência geralmente mostra que algo está aumentando ou diminuindo com uma taxa fixa (MARCUZZO Et al., 2012). Fez-se em seguida o teste para o coeficiente angular do modelo estimado da regressão linear, como mostram as fórmula 03 e 04 :

$$
\hat{y}=b_{0}+b_{1} x, \quad \mathrm{f} .03
$$

onde $\hat{y}$ representa a precipitação pluviométrica estimada, $b_{0}$ é o intercepto da reta de regressão estimada com o eixo y e $b_{1}$ é o coeficiente angular desta reta, cujas hipóteses estabelecidas foram: 
$H_{0}: b_{1}=0$ e $H_{1}: b_{1} \neq 0 . \quad$ f.04

Depois da elaboração de cálculos e gráficos, os resultados aqui obtidos foram analisados e comparados à pesquisa bibliográfica.

\section{Resultados}

Sistemas atmosféricos atuantes no Nordeste semiárido e em Caicó

Caicó é um município que está suscetível a grandes variações no total de precipitação, como será mostrado mais adiante. Por fazer parte do interior do estado do Rio Grande do Norte, está submetido aos mesmos sistemas sinóticos que atuam no semiárido nordestino. Atuam no Nordeste brasileiro os sistemas semipermanentes de altas pressões subtropicais que originam as massas de ar que agem de forma direta na região. São essas a Massa Tropical Atlântica (mTa) e a Massa Equatorial Atlântica (mEa). Seria a mEa responsável pela formação de chuvas no interior do continente da Massa Equatorial Continental (mEc) (ALVES; NASCIMENTO, 2010). Os principais sistemas atuantes na região, por ordem de influência, seriam a Zona de Convergência Intertropical (ZCIT), originada do encontro dos ventos alísios de nordeste e de sudeste relacionados a (mEa) e a $(\mathrm{mTa})$ respectivamente, o El Niño Oscilação Sul (ENOS), as Instabilidades Tropicais (IT) e por fim e com menor influência sobre a região semiárida, as Ondas de Leste (KANE, 1993; FERREIRA; MELLO, 2005; AIRES; NASCIMENTO, 2011). Os sistemas atmosféricos atuantes e a sua interação com a geografia local estão associados aos anos considerados normais (com chuvas próximas à média), secos ou chuvosos.

Grande parte dos estudos revisados associou a posição mais ao sul da ZCIT com anos mais chuvosos no semiárido nordestino e sua posição mais ao norte com os anos secos (figura 02). A ZCIT é considerada o principal sistema responsável pelo excesso ou falta de chuva em diferentes anos no semiárido brasileiro (NIMER, 1979; CAVALCANTI, 2009; VALADÃO Et al., 2010). Estudos posteriores têm dado muita ênfase ao ENOS, enfatizando a correlação dos anos de El Niño com períodos mais secos e dos anos de La Niña com os períodos mais chuvosos para a mesma região (CAVALCANTI, 2009; MOLION, 2011).

Alguns autores têm voltado os olhares para o oceano Atlântico Equatorial, relacionando a sua elevada temperatura com instabilidades causadoras de chuva. A atuação das Ondas de Leste, que é 
muito mais limitada à faixa litorânea oriental do Nordeste brasileiro (zona de clima litorâneo úmido), a depender de sua intensidade, pode levar alguma chuva para o interior da região Nordeste, onde ocorre o núcleo de semiaridez.

Estudos que relacionam as anomalias na Temperatura da Superfície do Mar (TSM), tanto no Atlântico como no Pacífico, têm sido realizados no intuito de se entender o padrão de chuvas na região, ajudando assim nas previsões climáticas e do tempo, uma vez que em regiões de grande variabilidade climática a população e outros seres vivos podem ser surpreendidos por anos de fortes chuvas ou de secas severas, que somado à falta de recursos e estrutura, submete a população a situação de grande vulnerabilidade. Kayano e Andreoli (2006 apud Cavalcanti Et al., 2009), em estudos realizados recentemente apontam para a importância do Atlântico Tropical Sul afirmando que as chuvas no Nordeste dependem mais do Atlântico do que do Pacífico. De fato, diversos autores concordam que as chuvas ou as secas no Nordeste semiárido dependem de vários sistemas dinâmicos da atmosfera de escala global e sinótica, bem como de algumas características físicas da região. A própria movimentação da ZCIT relatada por Nimer (1979) estaria relacionada às posições dos anticiclones de Açores ao norte e Santa Helena ao sul, que por sua vez podem estar relacionados às anomalias de temperatura do Atlântico Norte e Sul. Neste caso, as chuvas provenientes da ZCIT ocorreriam com maior intensidade no Nordeste do Brasil no período de verão e outono no nosso hemisfério, quando o Atlântico Equatorial estivesse mais aquecido e o anticiclone do Açores em sua posição mais austral, trazendo nebulosidade para a região (figura 02).
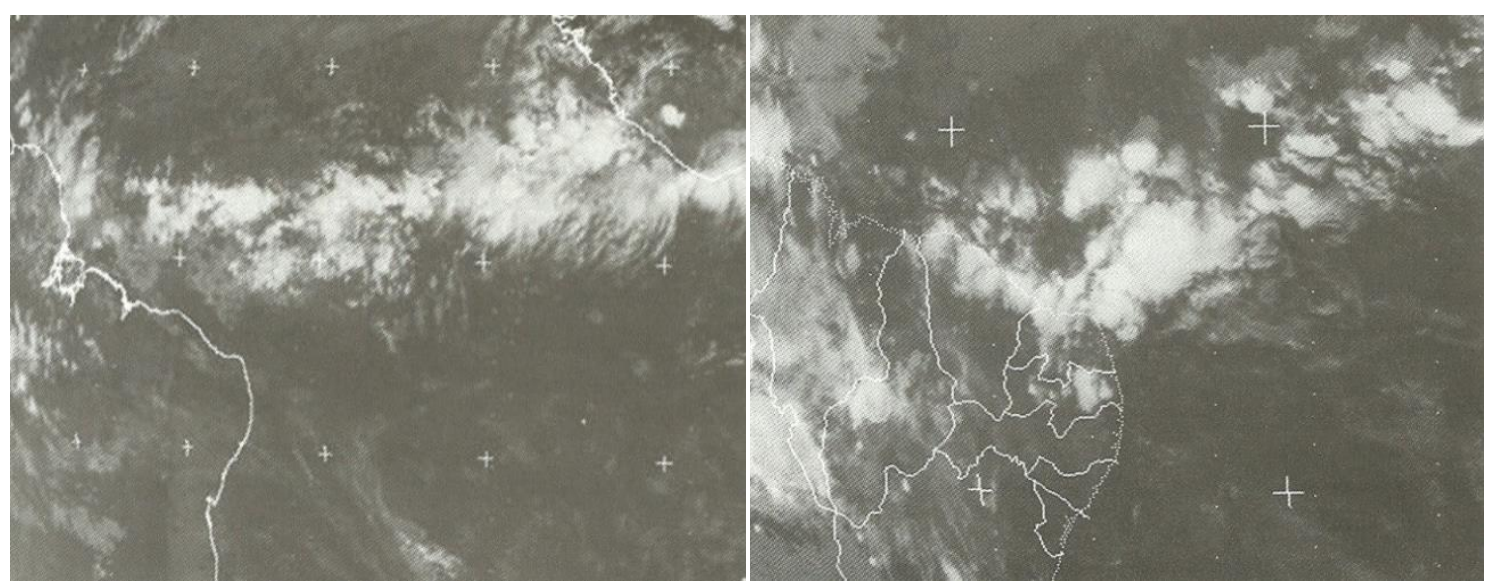

Figura 2 Imagens do satélite Meteosat (IR), onde se pode observar a banda de nebulosidade produzida pela FIT (ZCIT) em momentos distintos.

Fonte: Cavalcanti Et al., 2009. 
Todavia, são os trabalhos referentes ao oceano Pacífico que mais têm sido publicados e divulgados com relação ao padrão de chuvas para a região Nordeste. Cavalcanti et al, (2009), citando diversos trabalhos relacionados aos padrões de circulação atmosférica responsáveis por períodos de chuva e seca no Nordeste brasileiro, coloca o El Niño Oscilação Sul ou ENOS como um dos principais culpados pela flutuação das precipitações nesta região. A exemplo do estudo de Walker (1928 apud CAVALCANTI et al, 2009), que documentou a relação entre o aquecimento anormal das águas do Pacífico Equatorial Leste e as secas no Nordeste brasileiro, por meio de uma equação de regressão para prever as secas no Nordeste.

O El Niño pode ser descrito como o aquecimento anômalo das águas do Pacifico Leste e a $L a$ Niña como sendo o oposto, ou seja, o arrefecimento anômalo das águas do Pacífico Leste. Tais situações de anomalia de temperatura do Pacífico estariam arroladas ao padrão de circulação atmosférica nas proximidades do Equador, promovendo períodos chuvosos ( La Niña) e secos (El Niño) no NEB. A fase fria do ENOS está relacionada à La Niña e a quente ao El Niño (MOLION, 2008).

Estudos pautados no entendimento de fenômenos meteoro-oceanográficos, como Oscilação Decadal do Pacífico - ODP, também tentam analisar a relação entre as oscilações de temperatura no oceano Pacífico com períodos mais chuvosos ou secos no Nordeste brasileiro. Molion (2008), em estudo realizado sobre a previsão para o clima nos próximos 20 anos, afirma que aumentará a ocorrência de fenômenos do tipo La Niña, porém lembra que a última fase de La Niña não produziu totais de precipitação superiores a média de longo prazo para as regiões Norte e Nordeste do Brasil. Kane (1993), em estudo realizado sobre a característica das chuvas em diferentes partes do Nordeste brasileiro, relatou não haver correlação expressiva entre a variabilidade das chuvas nesta região e os eventos de El Niño Oscilação Sul.

Logo se percebe que as condições climáticas em Caicó, no que se refere às chuvas, se enquadram neste arquétipo de complexidade que atua sobre a região semiárida do Brasil. Sendo assim, pode haver a atuação conjunta dos sistemas, ou a ação isolada de apenas um sistema, operando em anos distintos e gerando precipitações típicas de anos normais, chuvosos ou secos, sucessivamente.

Análise das normais climatológicas (1911 - 2010)

Com relação à análise dos dados de precipitação no município de Caicó, as normais climatológicas mostraram que o trimestre mais chuvoso no último século compreendeu os meses de 
fevereiro, março e abril (figura 03). Corroborando os dados aqui gerados, Santos Et al. (2010) ao calcular o balanço hídrico de Tornthwaite and Matter (1955, apud Santos Et al. 2010) para as microrregiões do Seridó Oriental e Ocidental do RN, de 1963 - 2008, detectaram que o período chuvoso ocorre no primeiro semestre do ano.

Para o mês mais chuvoso, apenas no intervalo de 1991-1930 abril detém os maiores índices, pois nos outros períodos subseqüentes 1931-2010 (de 1931-1960, 1961-1990 e 1991-2010) o mês mais chuvoso foi março. Valadão Et al. (2010), em estudo realizado sobre o clima do Seridó potiguar, apresentaram março como o mês mais chuvoso em 17 municípios da região, no período de 1963-2008, incluindo o de Caicó.

Todas as normais climatológicas geradas para o município de Caicó mostraram que a partir do mês de junho ocorre uma drástica diminuição das chuvas. Elas permanecem em níveis baixos (entre 0 e $30 \mathrm{~mm}$ mensais, aproximadamente) até o mês de novembro, período que compreende a estação seca no Seridó potiguar. Conforme Mendonça, Danni-Oliveira (2007), o período de primavera é marcado pela falta de chuva em quase todo território brasileiro.

O trimestre mais seco foi agosto, setembro e outubro, entre 1911 a 1960, e setembro, outubro e novembro, entre 1961 a 2010. Fica evidente que o período chuvoso em Caicó ocorre no primeiro semestre do ano e que o período seco ocorre no segundo semestre do ano (ver figura 03). 


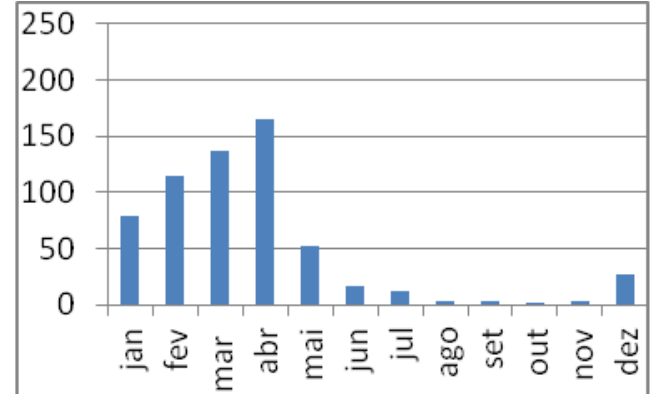

(a)

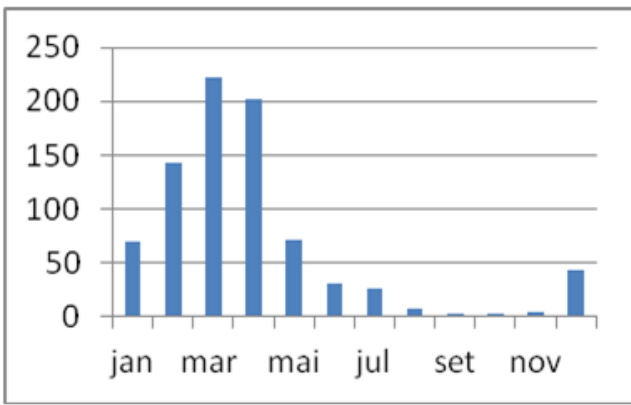

(c)

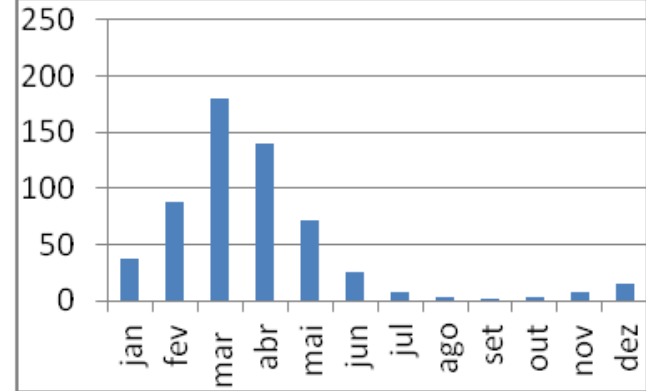

(b)

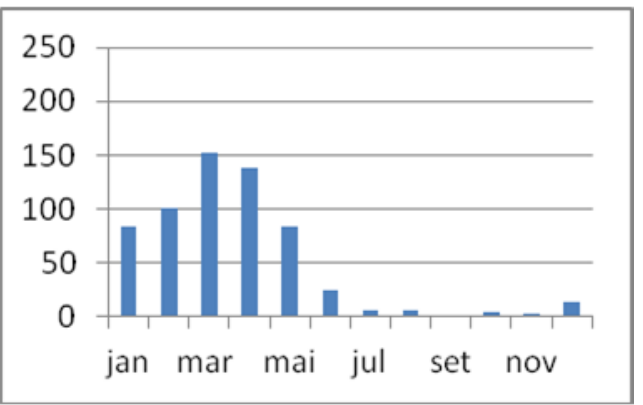

(d)

Figura 3 (a) meia normal de 1911 a 1930, (b) normal climatológica de 1931 a 1960, (c) normal climatológica de 1961-1990 e (d) normal provisória de 1991 a 2010. Os dados referem-se à quantidade média de chuva precipitada (em milímetros) em Caicó.

Fonte: Dados da pesquisa, 2012.

No entanto, é interessante ressaltar que nos últimos anos parece ter havido certo atraso anual com relação aos períodos de chuva e seca, a exemplo do trimestre mais seco que passou de agosto, setembro e outubro para setembro, outubro e novembro. Este fato mostra que houve uma tênue variação no regime anual da precipitação em Caicó e que alguma atenção deve ser dada a este aspecto em se tratando do manejo dos recursos hídricos com vistas ao planejamento urbano e rural.

Análise dos gráficos ombrotérmicos (1996 - 2010)

Nesta etapa, foi realizada a análise dos gráficos de precipitação e temperatura em Caicó, de acordo com a fórmula de mês seco de Gaussen, explicitada na seção de metodologia. A série temporal utilizada foi de 1996-2010, porque os dados de temperatura só estão disponíveis a partir de 1995. Os dados de temperatura média provêm de coletas diárias realizadas na Estação Climatológica do Seridó, situada no Campus da UFRN, em Caicó. 
Para este período de 15 anos, foram feitos 16 gráficos ombrotérmicos, um para cada ano supracitado de 1996 a 2010 e um da média dos 15 anos. Destes 15 gráficos, foram escolhidos 3 como representativos, sendo 1 de um ano normal, 1 para um ano seco e outro para um ano chuvoso. Os resultados mostram uma média de 7 meses secos no ano para os 15 anos de análise, sendo este período iniciado no mês de junho indo até dezembro (figura 04). A deficiência hídrica é, portanto, elevada na região, concentrando-se no período de junho a dezembro.

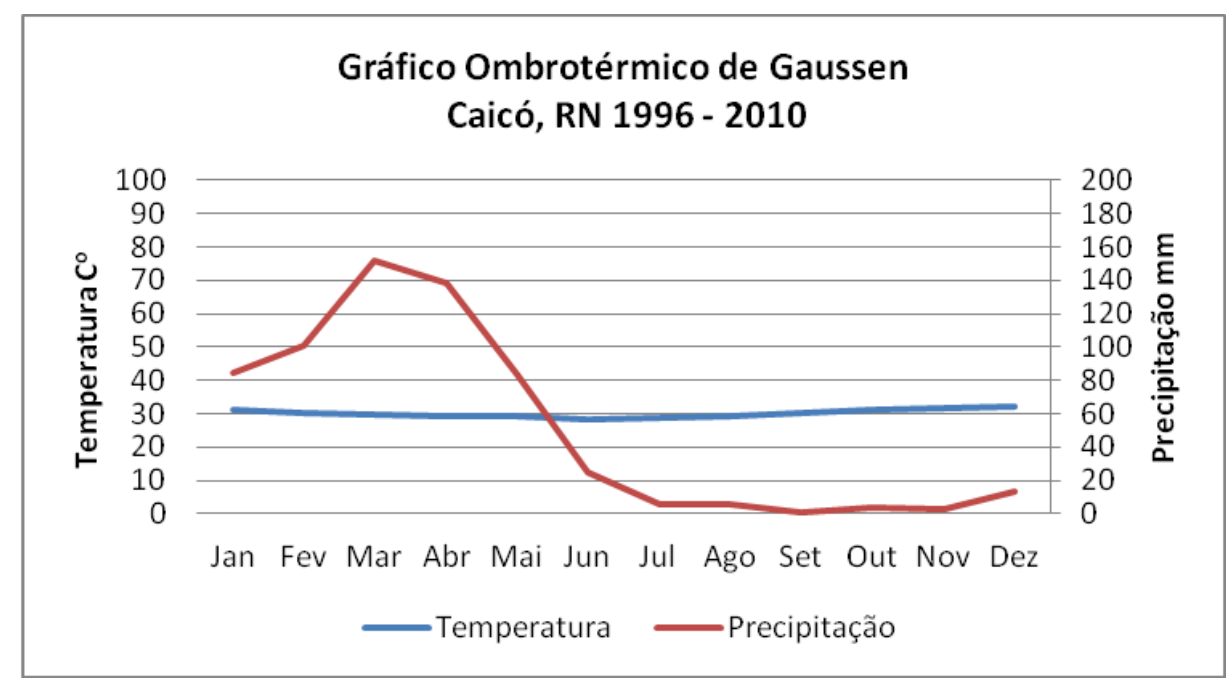

Figura 4 Gráfico ombrotérmico de Gaussen elaborado para o período de 15 anos. Os meses em que a linha de precipitação estiver abaixo da linha de temperatura são considerados biologicamente secos, com implicações ao desenvolvimento de vida vegetal.

Fonte: Dados da pesquisa, 2012.

O comportamento ombrotérmico em um ano considerado normal, ou seja, em um ano onde as chuvas estiveram próximas à média é aproximado ao do gráfico da figura 04. Em 2000, por exemplo, ano considerado normal, o total de precipitação anual foi de $657.1 \mathrm{~mm}$, e teve uma média de temperatura de $29.2{ }^{\circ} \mathrm{C}$. Além disso, cinco meses apresentaram precipitação igual ou acima do dobro da temperatura, sendo eles: Janeiro, com 66.6mm, Fevereiro, com 184.2mm, Março, com 114mm e Abril, com 161 mm. Os outros meses do ano obtiveram precipitações abaixo do dobro da temperatura, sendo considerados meses secos, mas, apenas dois tiveram precipitação nula: Outubro e Novembro. A figura 05 traz o comportamento ombrotérmico de um ano considerado chuvoso. 


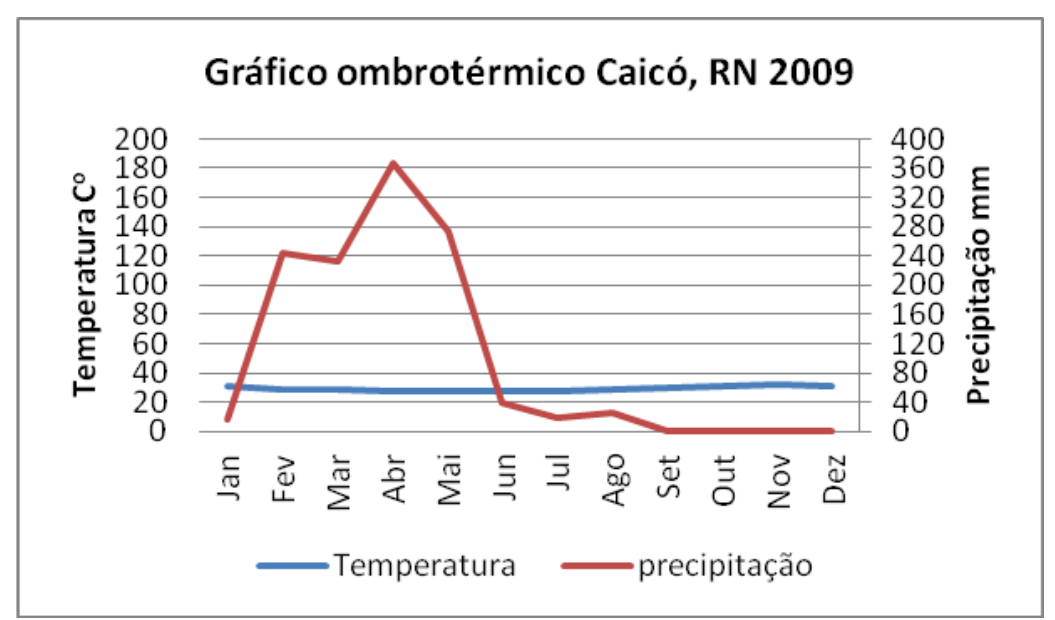

Figura 5 Gráfico ombrotérmico de Gaussen para o ano 2009, ano considerado chuvoso - precipitação total $1191.2 \mathrm{~mm}$.

Fonte: Dados da pesquisa, 2012.

O ano de 2009 também apresentou um período chuvoso eficiente entre fevereiro e maio, com índices de precipitação que ultrapassaram os 350mm no mês de abril. Porém, assim como em outros anos, após o mês de maio, os índices pluviométricos caíram, tendo vários meses de precipitação nula. O total pluviométrico de 2009 foi de $1191.2 \mathrm{~mm}$ e a média da temperatura foi de $31.8^{\circ} \mathrm{C}$. Já a figura 06 traz o comportamento ombrotérmico de um ano seco.

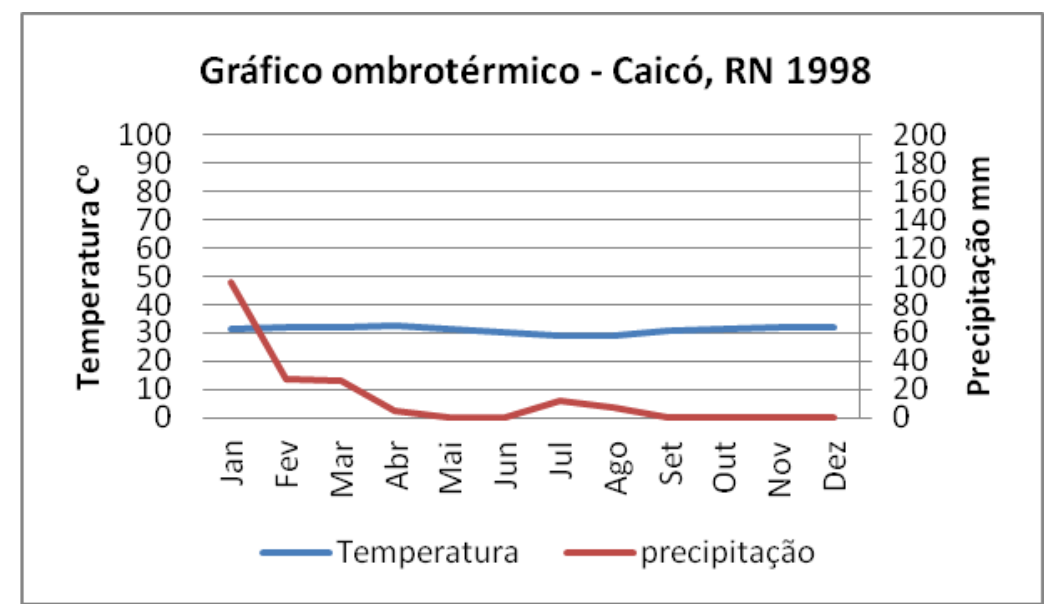

Figura 6 Gráfico ombrotérmico de Gaussen para o ano 1998, ano considerado seco - precipitação total $174.6 \mathrm{~mm}$.

Fonte: Dados da pesquisa, 2012.

O ano de 1998 apresentou baixa precipitação, sendo o total desta $174.6 \mathrm{~mm}$, ou seja, pouquíssima quantidade de chuva para o ano com maior média de temperatura da série temporal 
analisada: $33.5^{\circ} \mathrm{C}$. O mês de janeiro foi o único a apresentar precipitação maior do que o dobro da temperatura, ou seja, em janeiro precipitou $96 \mathrm{~mm}$. Os demais 11 meses (fevereiro a dezembro) se encaixam na definição de mês seco de Gaussen. Vale salientar que a maioria dos meses tem precipitação nula, causando déficit hídrico no município, onde existem temperaturas elevadas, intensa evaporação e nenhuma chuva.

Após a análise dos gráficos ombrotérmicas, percebe-se que, no município de Caicó, o superávit hídrico se faz presente entre os meses de janeiro e maio em um ano normal, ou seja, o período chuvoso no município. A partir de maio e indo até meados de novembro ou dezembro, os gráficos ombrotérmicos mostram déficit hídrico ou meses biologicamente secos e, em muitos casos, esses meses apresentam precipitação nula.

Como afirmam Bezerra Júnior, Silva (2007), devido ao déficit hídrico intenso que ocorre na região do Seridó, existem hoje construídas inúmeras barragens que trazem oportunidades para prática de irrigação, uso humano e turismo no intuito de diminuir as dificuldades socioeconômicas que se apresentam na época da seca. No entanto, muitas destas barragens ficam susceptíveis a períodos secos que ultrapassam 2 anos consecutivos.

Análise da variabilidade interanual e tendência da precipitação (1911 - 2010)

Em se tratando do total anual de precipitação e da sua variabilidade nos últimos 100 anos, notou-se que as chuvas variaram fortemente de ano pra ano. Foram registrados anos com totais de $107 \mathrm{~mm}$ e $1.561 \mathrm{~mm}$, como pode ser visto na figura 07 . A precipitação média anual para o período estudado (1911 a 2010) foi de 659,94mm. 


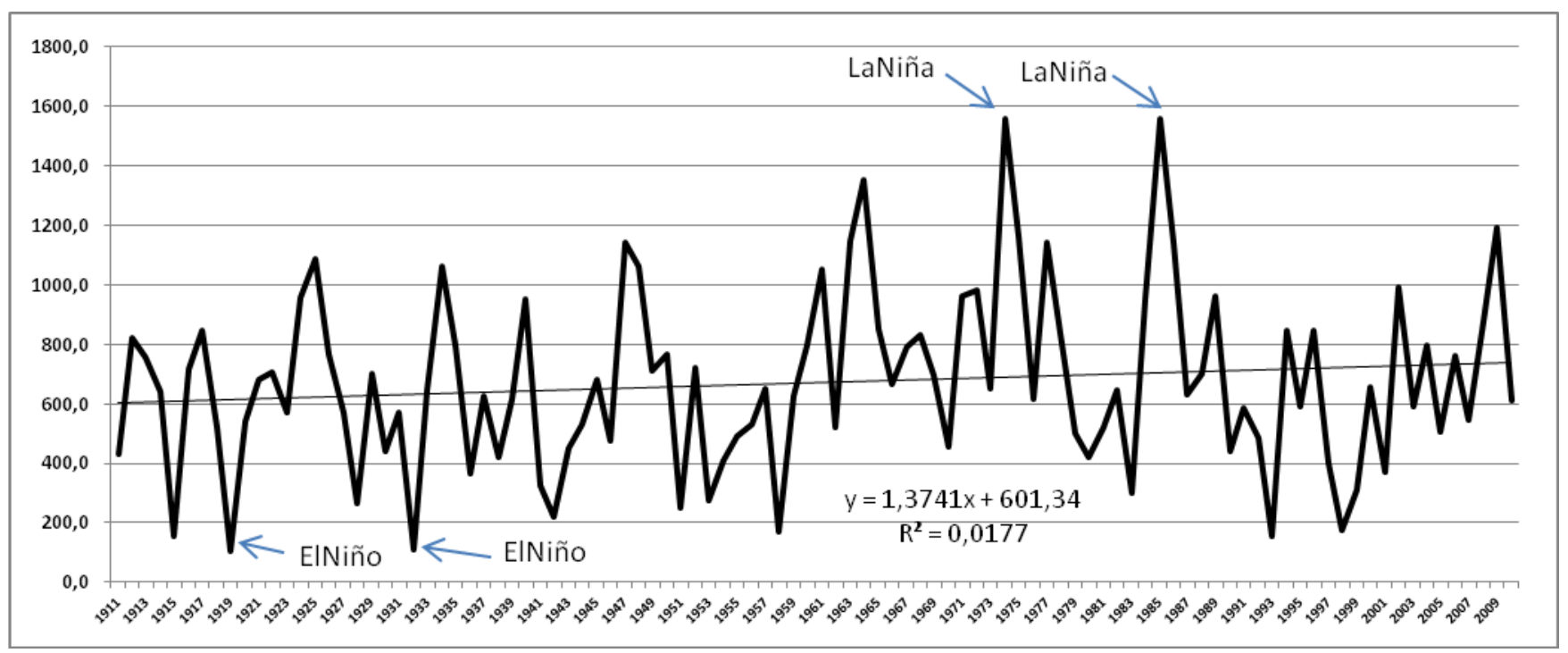

Figura 7 Total anual de chuva em milímetros no município de Caicó - RN de 1911 a 2010, com linha de tendência de previsão e destaque para dois episódios intensos de El Niño e dois de La Niña.

Fonte: Dados da pesquisa, 2013.

A figura 07 exibe uma série temporal de 100 anos de precipitação pluviométrica (mm) e uma reta de regressão estimada, na qual o coeficiente angular não se mostrou estatisticamente significativo. Trata-se, então, de uma série estacionária, constatada pelo teste para o coeficiente angular da reta de regressão $(\mathrm{p}=0,186)$. Mesmo apresentando-se como uma série estacionária com relação à tendência, o ritmo de precipitação no município de Caicó nos últimos 100 anos apresentou totais de precipitação mais elevados na segunda metade do século.

Cabe destacar na figura 07 o período que vai de 1961 a 1990, onde se registraram os maiores totais anuais de precipitação no último século no município de Caicó. Os três maiores picos de chuva ocorreram nesse período, especificamente nos anos de 1964, 1974 e 1985. Vale ressaltar que os anos de 1964 e 1985 foram marcados por fortes episódios de La Niña, como relatado por Grimm (1998). Também se destacam dois fortes episódios de El Niño onde as precipitações foram as mais baixas do século, nos anos de 1915 e 1932.

Se analisarmos dois períodos apenas 1911-1960 e 1961-2010, podemos perceber que o total de precipitação entre 1911-1960 é bem mais baixo que o total para o período 1961-2010, e que o primeiro período apresentou maior número de anos com chuvas abaixo da média.

Logo, percebe-se que no município de Caicó a variabilidade no total anual de precipitação é comum e que o planejamento e a gestão dos recursos hídricos neste município devem estar adaptados 
não só aos anos secos, mas também aos anos de chuvas abundantes, pois estes fornecem fartura de água que deveria ser armazenada adequadamente para os anos secos.

No sentido de não permanecer em situação de alta vulnerabilidade em detrimento do comportamento irregular das chuvas no Nordeste brasileiro, a partir do ano de 1930, o Departamento Nacional de Obras Contra as Secas - DNOCS realizou um programa para a açudagem, construindo grandes reservatórios de água para abastecer as cidades e as zonas rurais semiáridas nos períodos de seca. Hoje esses açudes são responsáveis pelo abastecimento de água em diversas localidades da região, desde povoados até cidades de médio porte. Conforme Malvezzi (2007), todos os investimentos dos governos na região semiárida concentraram-se em grandes açudes. Se o semiárido brasileiro é hoje uma das regiões mais açudadas do planeta, em grande parte isso se deve ao DNOCS.

Também no sentido se evitar a vulnerabilidade social aos eventos climáticos, as previsões de tempo servem para a sociedade se precaver contra eventos climáticos que possam ocorrer prejudicando o desenvolvimento destas sociedades. É por meio do planejamento que as pessoas podem se adaptar a determinados tipos de clima ou épocas do ano, adequando suas atividades para haver melhor desenvolvimento em todos os níveis. No entanto, sabemos que apesar do forte desenvolvimento tecnológico que vem se desenvolvendo, a partir da década de 1960 especialmente, quando do lançamento do primeiro satélite meteorológico, a atmosfera da Terra, seus movimentos e interações com diferentes superfícies determinam padrões dinâmicos ainda não esclarecidos totalmente pelos estudos científicos do clima.

Com relação a projeções futuras podemos citar os vários modelos de previsão do clima expostos no Intergovernmental Panel on Climate Change - IPCC que diferem uns dos outros em relação aos prognósticos para o clima mundial. Apesar do relatório do IPCC de 2007 afirmar que “secas mais longas e mais intensas têm sido observadas em áreas cada vez maiores desde a década de 1970, principalmente nas regiões tropicais e subtropicais" (IPCC, 2007 p. 7), estudos têm verificado um aumento das chuvas elou mesmo uma tendência ao aumento delas em muitas porções do semiárido nordestino, se contrapondo aos estudos que indicam diminuição das chuvas nesta região tropical do globo.

Conti (2008), a partir da utilização do método das séries temporais, analisou o comportamento das precipitações em diversas cidades do Nordeste e o resultado que obteve indicou 49,7\% das séries apresentando tendência crescente nas médias pluviométricas, com incidência maior nos estados do Rio Grande do Norte, de Pernambuco e Paraíba, sobretudo no espaço compreendido entre o reverso 
continental da Borborema e chapada do Apodi. Ainda de acordo com este autor, tal constatação indica que a precipitação em nível regional acompanha a tendência de elevação da média pluviométrica que vem sendo registrada nas últimas décadas, presumivelmente associada ao agravamento do efeito de estufa.

Assim, é normal que o planeta naturalmente apresente anos com invernos mais ou menos rigorosos, devido a fatores astronômicos. Da mesma forma, atividades vulcânicas, ciclos solares, atividades humanas desenfreadas podem exercer influência na dinâmica atmosférica alterando os padrões de chuva no território brasileiro e, por conseguinte no Seridó potiguar.

Enfim, corrobora-se com o dizer de Molion (2011) quando este afirma que as tentativas de se transformar o quadro da semiaridez do Nordeste brasileiro por meio de técnicas modernas, como a adubação de nuvens, não trarão resultados positivos uma vez que a situação climática da região é causada por sistemas climáticos de escala global e regional e de sua interação com a geografia local. “O bem estar da população e o desenvolvimento econômico só poderão ser alcançados se for garantido um suprimento de água contínuo e confiável, uma vez que as chuvas, como o clima atual, são altamente variáveis no espaço e no tempo" (MOLION, 2011, p.1341).

\section{Conclusões}

Em um século de observação e registro das precipitações no município de Caicó, notou-se que as chuvas variaram fortemente de ano pra ano tendo sido registrado 107,1mm em 1919 e $1561 \mathrm{~mm}$ em 1974. Estes números mostram que a precipitação pode variar em até 15 vezes de um ano para outro. A média anual para o período de um século (1911 a 2010) foi de 659,94mm, sendo este número considerado baixo mais devido a outros parâmetros do que a ele próprio, uma vez que as variáveis temperatura e evaporação são bem elevadas nesta região por quase todo o ano.

Apesar das grandes variações no total anual de chuva, as normais climatológicas apontam uma distribuição relativamente regular das chuvas durante os meses do ano, estando bem definidas as estações chuvosa e seca, sendo a chuvosa no primeiro semestre do ano e a seca no segundo semestre do ano. Logo, o ritmo anual das chuvas em Caicó mostrou-se estável no que diz respeito aos meses secos e chuvosos. O trimestre mais chuvoso no ultimo século foi fevereiro, março e abril. O trimestre considerado mais seco entre 1911 a 1960 foi agosto, setembro e outubro, e entre 1961 a 2010 foi setembro, outubro e novembro. 
No que se refere aos gráficos ombrotérmicos, percebeu-se que o déficit hídrico supera os meses de superávit, pois, o período seco é mais prolongado que o chuvoso. Sendo assim, notou-se que em anos de pouca chuva as elevadas temperaturas se fazem presentes, contribuindo cada vez mais com o déficit hídrico.

Quanto à tendência secular das chuvas, viu-se que se trata de uma série estacionária. O período que pode ser considerado anômalo na série de um século é o de 1961-1990, onde a média de precipitação foi maior que $800 \mathrm{~mm}$ e se registraram os três maiores picos de chuva desde que existe registro no município, sendo dois destes episódios em anos de La Niña, como os de 1974 e 1985.

Apesar do relatório do IPCC de 2007 prever que eventos de secas serão mais freqüentes e severos nas regiões semiáridas tropicais da Terra nos próximos anos (IPCC, 2007), os dados aqui gerados mostram que as grandes variabilidades no total de chuvas anual sempre ocorreram e que a tendência de previsão não aponta aumento ou decréscimo significativo das chuvas para Caicó, no semiárido nordestino.

Por último, concluiu-se que a instabilidade e a variabilidade das chuvas são condições inerentes ao clima de Caicó/RN e que, diante das dificuldades de previsão das precipitações para os anos vindouros, as ações de planejamento e gestão dos recursos hídricos, através de armazenagem e distribuição adequadas da água para os mais diversos usos, devem ser prioridade nas ações de planejamento e gestão do meio urbano e rural deste município, bem como de outros situados nesta mesma condição climática.

\section{Referencias Bibliográficas}

AB'SABER, A. N. Caatingas: O domínio dos sertões secos. In: Os domínios de natureza no Brasil: potencialidades paisagísticas. 1 $^{\mathrm{a}}$ Ed. São Paulo: Ateliê Editorial, 2003.

AIRES, R.; NASCIMENTO, F. R.. Variações pluviométricas em microbacias no vale do Jaguaribe, CE. Revista da Casa da Geografia de Sobral. Sobral, vol. 13, n. 1, p. 83-97, 2011.

ALVES, J. J. A.; NASCIMENTO, S. S. Avaliação Ecoclimática do Seridó paraibano. CLIMEP Climatologia e Estudos da Paisagem. Rio Claro, vol. 5, n.2, p. 140-159, jul./dez. 2010.

AYOADE, J. O. Introdução à climatologia para os trópicos. $12^{\mathrm{a}}$ Ed. Rio de Janeiro: Bertrand Brasil, 2007.

BEZERRA JUNIOR, J. G. O.; SILVA, N. M. Caracterização Geoambiental da microrregião do Seridó Oriental do Rio Grande do Norte. Revista Holos. Natal, vol 2, ano 23, p. 78-91, 2007. 
BRANCO, S. M. Caatinga: a paisagem e o homem sertanejo. $2^{\mathrm{a}}$ ed. São Paulo: Moderna, 2003.

CAVAlCANTI, I. F. A.; FERREIRA, N. J.; SILVA, M. G. A. J.; DIAS, M. A. F. da S. Tempo e clima no Brasil. São Paulo: Oficina de Textos, 2009.CONTI, J. B. O conceito de desertificação. CLIMEP - Climatologia e Estudos da Paisagem. Rio Claro, vol.3, n.2, p. 39-52, jul./dez. 2008.

COSTA, Júlio Cesar da Silva. Caracterização geológica e geomorfológica da porção sul do município de Caicó/RN, com base em imagens de sensores remotos ativos e passivos. Relatório de Pesquisa (Geologia), Universidade Federal do Rio Grande do Norte, Natal, 2006.

FERREIRA, A. G.; MELLO, N. G. da S. Principais sistemas atmosféricos atuantes sobre a região Nordeste do Brasil e a influência dos oceanos Pacífico e Atlântico no clima da região. Revista brasileira de Climatologia. Curitiba, vol 1, n. 1, p. 15-28, dez. 2005.

FERREIRA, H. F. P. de A. Analise climatológica da precipitação pluviométrica no município de Caicó/RN entre 1911-2010. 2012. 65 f. Monografia (Geografia), Departamento de Geografia, Universidade Federal do Rio Grande do Norte, Caicó, 2012.

GALVANI, E. Métodos e técnicas de quantificação em Geografia. In: VENTURI, L. A. B. Praticando Geografia: Técnicas de Campo e Laboratório. 1 ${ }^{\text {a }}$ Ed. Vol 1. São Paulo: Oficina de Textos, 2005.

GRIMM, A. M. ; FERRAZ, S. E. T. ; CARDOSO, A. O. . Influência de El Niño sobre a chuva do Nordeste brasileiro. In: Congresso Brasileiro de Meteorologia e VIII Congresso da FLISMET, 10, 1998, Brasília. Anais eletrônicos.. Brasília, DF: Sociedade Brasileira de Meteorologia, 1998. Disponível em: < $\underline{\text { http://www.cbmet.com/cbm-files/13-42b77c25584315197f4b38c8ed6039d0.pdf. }>~}$ Acesso em: 15 fev 2013.

IDEMA (Instituto de Desenvolvimento Econômico e do Meio Ambiente do Rio Grande do Norte). Perfil do Estado do Rio Grande do Norte. Secretaria de Estado do Planejamento e das Finanças do Rio Grande do Norte: Natal, 2005.

IPCC (Intergovernmental Panel on Climate Change). Mudança do Clima 2007: a Base das Ciências Físicas. Relatório do IPCC/ONU, novos cenários climáticos, Versão em português: iniciativa da Ecolatina 1. Disponível em: <http://www.natbrasil.org.br/Docs/ipcc_2007.pdf $>$. Acesso em $01 \mathrm{dez}$. 2007.

KANE, R. P. Rainfall characteristics in different parts of Northeast Brazil. Revista Brasileira de Geofísica. Rio de Janeiro, vol 11, n. 1, p. 7-22, 1993.

MALVEZZI, R. Semi-Árido: uma visão holística. Brasília: Confea, 2007.

MARCUZZO, F.; FARIA, T. G.; FILHO, R. de F. P. Chuvas no estado de Goiás: análise histórica e tendência futura. ACTA Geográfica. Boa Vista, vol. 6, n. 12. p. 125-137, mai./ago. 2012.

MENDONÇA, F \& DANNI-OLIVEIRA. Climatologia: Noções básicas e climas do Brasil. São Paulo: Oficina de Textos, 2007. 
MOLION, L. C. B. Dinâmica das chuvas no Nordeste brasileiro. Disponível em: $<$ http://www.cbmet.com/cbm-files/12-7ea5f627d14a9f9a88cc694cf707236f.pdf.> Acesso em 12 jun 2011.

MOLION. L. C. B. Perspectivas climáticas para os próximos 20 anos. Revista Brasileira de Climatologia. Curitiba, vol. 3/4, p. 117-128. ago, 2008.

MONTEIRO, M. A. de A.. Eventos hidrometeóricos intensos e problemas socioambientais decorrentes: o caso do Rio Barra Nova, Caicó/RN. 2012. 70 f. Monografia (Geografia), Departamento de Geografia, Universidade Federal do Rio Grande do Norte, Caicó, 2012.

NIMER, E. As novas classificações bioclimáticas e suas aplicações no Brasil. In: NIMER, E.; SILVA, J. X.; LIMA, G.R. Curso de Geografia para professores do ensino superior: Geografia física. IBGE - Instituto Brasileiro de Geografia e Estatística: Divisão Cultural, 1967. Disponível em: $<$ http://biblioteca.ibge.gov.br/visualizacao/monografias/GEBIS $\% 20 \% 20 \mathrm{RJ} /$ CursodeFerias/curso $\% 20$ de $\% 20$ geografia $\% 20$ para $\% 20$ prof $\% 20$ do\%20ensino\%20superior_julho_1967.pdf.> Acesso em 10 set. 2013.

NIMER, Edmon. Climatologia do Brasil. Rio de Janeiro: IBGE, 1979.

OLIVEIRA, M. J. \& VECCHIA, F.. Elaboração de normais climatológicas: Caracterização e tendências de temperatura em Itirapina - SP, Brasil. In: XVI CBMET - Congresso Brasileiro de Meteorologia: 16, 2010. Anais.. Belém: CBMET, Sociedade Brasileira de Meteorologia, 2010.

PNUD - Programa das Nações Unidas para o Desenvolvimento. IDHM. Disponível em:

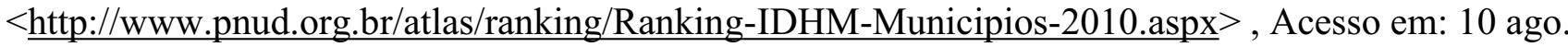
2013.

REBOITA, M. S. Introdução à Estatística Aplicada à Climatologia: Parte I Estatística Descritiva. Projeto PAE. São Paulo, 2005.

SANT'ANNA NETO, J. L. Ritmo climático e a gênese das chuvas na Zona Costeira Paulista. 1990. 168 f. Dissertação (Mestrado em Geografia Física) - Faculdade de Filosofia, Letras e Ciências Humanas, Universidade de São Paulo, São Paulo. 1990.

SANTOS, A.S.; MATTOS, A.; LOPO, A. B. Estimativa do Balanço Hídrico Climático para a Microrregião do Seridó - Estado do Rio Grande do Norte. 16, 2010. In: XVI Congresso Brasileiro de Meteorologia: Anais.. Belém: CBMET, Sociedade Brasileira de Meteorologia, 2010.

SETTI, A. A.; LIMA, J. E. F. W.; CHAVES, A. G. M.; PEREIRA, I. C. Introdução ao gerenciamento de recursos hídricos. 2a Ed. Brasília: ANEEL, 2001.

SUDENE (Superintendência de Desenvolvimento do Nordeste). Dados pluviométricos mensais do Nordeste: Estado do Rio Grande do Norte. Recife: SUDENE- DPG -PRN - HME, 1990.

TORRES, F. T. P.; MACHADO, P. J. de O. Introdução à climatologia. São Paulo: Cengage Learning, 2011. 
VALADÃO, C. E. A; OLIVEIRA, P. T.; SCHMIDT, D. M.; SILVA, B. K. N.; BARRETO N. J.C.; CORREIA FILHO, W. L.F.; JESUS E. S.; LOPO, A.B.; SANTOS A.S.; PINHEIRO, J.U.;

MATTOS, A. Classificação climática da microrregião do Seridó/RN. In: XVI Congresso Brasileiro de Meteorologia: Anais.. Belém: CBMET, Sociedade Brasileira de Meteorologia, 2010.

VASCONCELOS, M. E. G. de; SILANS, A. M. B. P. de. Gestão hidrica na Paraíba: indicadores de sustentabilidade. 19, 2011. XIX Simpósio Brasileiro de Recursos Hídricos. p. 1 - 20. Anais eletrônicos.. Maceio, AL. Disponível em

$<$ http://www.abrh.org.br/SGCv3/UserFiles/Sumarios/e46af8543e515536e5b25360dfa82b17_4eea77 09d1ee9744e01c2a3a557a73b6.pdf $>$. Acesso em: 22 dez. 2011. 


\section{CAPÍTULO 3 A condição higrotérmica}

Este capítulo tem como objetivo apresentar os resultados do estudo do campo térmico do município de Caicó no formato de dois artigos.

O primeiro artigo, "Calor e conforto humano em uma cidade da região semiárida do Brasil", em inglês com o título: "Heat and human comfort in a town in Brazil's semiarid region", foi publicado ${ }^{2}$ na revista International Journal of Climate Change: Impacts and Responses (presente no ANEXO dessa Tese), e discute a condição térmica a partir da aplicação de índices bioclimáticos de conforto humano no município de Caicó. Para tanto, utilizou-se dados de temperatura do ar, umidade relativa do ar e velocidade do vento de uma série temporal de 15 anos (meia normal) proveniente da estação climatológica do Seridó, onde a partir daí foram realizadas técnicas de estatística descritiva, tendência, e aplicados três diferentes índices bioclimáticos de conforto térmico.

O segundo artigo, “Análise higrotérmica do município de Caicó/RN/Brasil” teve como objetivo principal analisar as condições climáticas ao nível local (município), comparando diferentes locais na área urbanizada do município e um ponto na zona rural. Para a realização deste estudo foram instalados 11 aparelhos termohigrômetros registrando dados de temperatura do ar e umidade relativa do ar 24 horas por dia. $\mathrm{Na}$ análise foram utilizadas técnicas de estatística descritiva e aplicados índices bioclimáticos de conforto humano.

${ }^{2}$ Rebecca Luna Lucena; Tacio Henrique, Almir M. Ferreira; Ercília Torres Steinke . International Journal of Climate Change: Impacts and Responses, Volume 8, Issue 4, pp.15-30. Article: Print (Spiral Bound). Published online: June 16, 2016 (Article: Electronic) 
3.1 Artigo 1 Calor e conforto humano em uma cidade da região semiárida do Brasil

Autoria: Rebecca Luna Lucena; Tacio Henrique, Almir M. Ferreira; Ercília Torres Steinke

\title{
Resumo
}

O objetivo deste estudo foi avaliar a evolução da temperatura do ar registrada na cidade de Caicó, Rio Grande do Norte, Brasil, ao longo de um período de 15 anos (1996-2010), e analisar o conforto humano local utilizando índices de conforto térmico para o mesmo período. Para tanto, foram escolhidos e aplicados três índices: o Índice de Desconforto (DI), o índice de Temperatura Efetiva em função do Vento (TEv) e o Índice Climático Térmico Universal (UTCI). Trabalhos de campo também foram realizados para a tomada de registro fotográfico da cidade. Descobrimos que em Caicó a temperatura do ar é naturalmente muito elevada, com média por volta de $30^{\circ} \mathrm{C}$, máxima de $\sim 35^{\circ} \mathrm{C}$ e mínima de $24^{\circ} \mathrm{C}$, colocando Caicó no limite da zona de conforto humano quase todo o ano. Mesmo não tendo sido detectada qualquer tendência de mudança na temperatura do ar para o período estudado, os índices de conforto térmico mostraram que Caicó, durante todos os anos em questão, apresentou estresse moderado por causa do calor e que só na época do inverno, durante os meses de julho, agosto e de setembro o município não apresentou estresse térmico. Verificou-se também a falta de compatibilidade entre os materiais de construção utilizados e a arborização urbana com as características climáticas da cidade. Esta situação pode ser agravada no futuro, se as temperaturas do ar subirem devido ao aquecimento global, trazendo riscos para os habitantes locais.

Palavras-chave: Semiárido brasileiro, temperatura do ar, conforto térmico humano

\begin{abstract}
The aim of this study was to assess the evolution of registered air temperatures in the town of Caicó, Rio Grande do Norte, Brazil, over a 15-year period (from 1996 to 2010), analysing the heat susceptibility of the local inhabitants through the human comfort indices for the same period. In order to discuss the relationship between the temperatures and the issue of human thermal comfort in Caicó, three indices of human thermal comfort were applied: Discomfort Index (DI), the Effective Temperature taking wind velocity (ETv) and the Universal Thermal Climate Index (UTCI). We found that in Caico the air temperature is naturally very high, with daily means circa $30^{\circ} \mathrm{C}$, maximum temperatures $\sim 35^{\circ} \mathrm{C}$ and minimum temperatures around $24^{\circ} \mathrm{C}$, putting Caicó at the limit of the human comfort zone almost all year round. Even though temperature changes were not detected in the studied 15-year period, the thermal indices show us that Caicó was all the years (1996-2010) with thermal stress due to heat and only in the winter time, in July, August and September, Caicó has no thermal stress. We verified also a lack of compatibility between the construction materials used in the buildings, urban forestry, and the town's climatic reality in Caicó city. This situation could be exacerbated in the future if air temperatures rise due to global warming, bringing risks to the local inhabitants.
\end{abstract}

Keywords: Brazil's semi-arid region, air temperatures, human comfort indices. 


\section{INTRODUÇÃO}

Segundo as projeções dos cenários climáticos futuros publicadas pelo Intergovernamental Painel of Climate Change - IPCC, as temperaturas no planeta poderão aumentar $4,8^{\circ} \mathrm{C}$ até 2100 (IPCC, 2013). Para a região semiárida do Brasil, o prognóstico é de que haja um aumento para a estação do verão de $3^{\circ} \mathrm{C}$ para o mesmo período (MARENGO Et al, 2011). Tais projeções devem ser apreciadas com bastante atenção em lugares naturalmente quentes, como nas zonas entre os trópicos da Terra.

Tão importante quanto às mudanças climáticas e o aquecimento global propalados na atualidade, é o processo de globalização que produziu e vem produzindo resultados insatisfatórios na arquitetura em lugares com temperaturas naturalmente elevadas, como é o caso de grande parte do território brasileiro, onde os processos de urbanização mal planejados e mal adaptados ao clima local têm favorecido o aumento de calor oriundo da substituição do solo e vegetação por materiais de construção que ocasionam maior armazenamento de energia (OKE, 1996; BITTENCOURT, 2010).

Em um mundo em processo acelerado de urbanização, vê-se que em vários lugares, tem-se gerado transformações no solo alterando o balanço de radiação local, com tendência ao aumento das temperaturas, gerando um fenômeno conhecido por "ilhas de calor" nos aglomerados urbanos, que segundo Taha (1997) essas ilhas de calor têm sido reconhecidas e documentadas desde o início do século XX em diferentes escalas, causando efeitos distintos a partir da interação complexa entre as condições climáticas locais e as condições termofísicas e geométricas das áreas urbanizadas. Taha (1997), também afirma que, geralmente, em regiões de baixa latitude, as ilhas de calor não são bem vindas porque podem contribuir com o desconforto térmico humano e com a poluição do ar. A aglomeração humana nos espaços urbanos somada a aculturação em muitas cidades tropicais quentes, dentro de um modelo globalizado, resultam no uso de materiais de construção, vestimentas e hábitos de vida incompatíveis às exigências climática dessas regiões (RIBEIRO; OLIVEIRA, 2010). Além dos materiais utilizados na construção civil e das formas das edificações muitas vezes inadequados ao clima, a topografia local e a arborização urbana são fatores que devem ser sempre considerados num projeto urbanístico (BARBIRATO, 2010). A falta de arborização bem como a poda exagerada de árvores, que fazem parte da realidade de muitas cidades brasileiras, tem favorecido o desconforto térmico em pontos específicos das cidades. Disso resulta o desconforto térmico humano, que ocorre quando "as reações fissiológicas ao estresse térmico incluem mudanças no metabolismo, dilatação e 
contração dos vasos sanguíneos, aumento ou diminuição da pulsação cardíaca, sudorese, entre outras" (SANTOS; MELO, 2011 p.154). Tanto a utilização de materiais de baixo albedo quanto a falta de arborização são atributos que muito contribuem para condições de aumento no desconforto e até de problemas de saúde, interferindo na qualidade de vida da população sujeita a condições climáticas extremas em lugares quentes.

Diante dessas circunstâncias, o objetivo principal deste estudo foi analisar o comportamento das temperaturas no município de Caicó no estado do Rio Grande do Norte, analisando a susceptibilidade dos habitantes locais ao calor por meio da aplicação Índices de conforto humano cientificamente reconhecidos. Os índices de conforto térmico humano, apesar de se tratarem de classificações climáticas com muitas características subjetivas, envolvendo questões ligadas à percepção humana, são utilizados por diversos serviços meteorológicos em todo o mundo e podem ser facilmente medidos pelos usuários para descrever os potenciais processos de calor e termo-regulação a qual as pessoas são submetidas (Winslow, Herrington, Gagge, 1937; Blazejczyk, 2012). Estes índices são muito importantes para estudos climáticos, de saúde, urbanísticos e arquitetônicos, porém são complexos devido à subjetividade implícita. Estes índices representam, em um único parâmetro, o efeito combinado de duas ou mais variáveis climáticas (ASHRAE, 2009).

De acordo com Blazejczyk (2012):

\footnotetext{
"Ao longo do último século, tem havido muita pesquisa sobre como definir o conforto térmico e como classificar o estresse térmico. Estes esforços resultaram em vários modelos que tentam descrever o conforto térmico e o estresse térmico resultante. Um grande número de índices foi proposto, que estão (ou estavam) em uso em todo o mundo [cerca de 40 índices foram listados por Epstein e Moran (2006) e há muitos outros]. "(p.515).
}

Neste trabalho, escolhemos os índices mais práticos e utilizados, que consideram apenas variáveis meteorológicas, como o Índice de Desconforto (ID), Temperatura Efetiva em função do vento (TEv) e o Índice Climático Térmico Universal (ICTU). Eles foram usados por muitos cientistas na área, ID por Matzarakis, Mayer, 1991, Epstein, Moran, 2006; Yousif, Tahir, 2013; Ongoma, Muthama, 2014; Polydoros, Cartalis, 2015; TEv por Suping et al, 1992; Makokha, 1998; Nedel et al., 
2006; Blazejczyk, 2012 ;, e ICTU, estudado mais recentemente por Jendritzky et al, 2012; Blazejczyk, 2012, Abdel-Ghany et al, 2013; E Bröde et al., 2014.

Em um mundo cada vez mais urbanizado, os índices climáticos de conforto humano devem ser usados com mais frequência e melhorados para inferir a situação térmica das cidades com respeito ao conforto humano e qualidade de vida da população.

\section{LOCALIZAÇÃO DA ÁREA DE ESTUDO}

O município de Caicó está situado na região Nordeste do Brasil (figura 1) numa zona de baixa latitude a $6^{\circ} 27^{\prime} 30^{\prime \prime}$ Sul e a $37^{\circ} 05^{\prime} 52^{\prime}$ ' Oeste, com altitude média de 161 metros, o que lhe confere características climáticas bem particulares, como altas taxas de radiação e temperaturas elevadas durante todo o ano. Abrange uma área de $1.229 \mathrm{~km}^{2}$ (BRASIL, 2013) e é o mais importante município da região do Seridó, devido ao forte desenvolvimento relativo às atividades comerciais, da pecuária, dos grandes eventos festivos, do número de estabelecimentos de ensino, etc. Sua população estimada é de 63.000 habitantes (BRASIL, 2013). Caicó apresenta um bom Índice de Desenvolvimento Humano (IDH), se comparado ao IDH de outros municípios da região semiárida nordestina (média de $\sim 0,650$ ), sendo o de Caicó maior que 0,750 (SANTANA, 2007). 


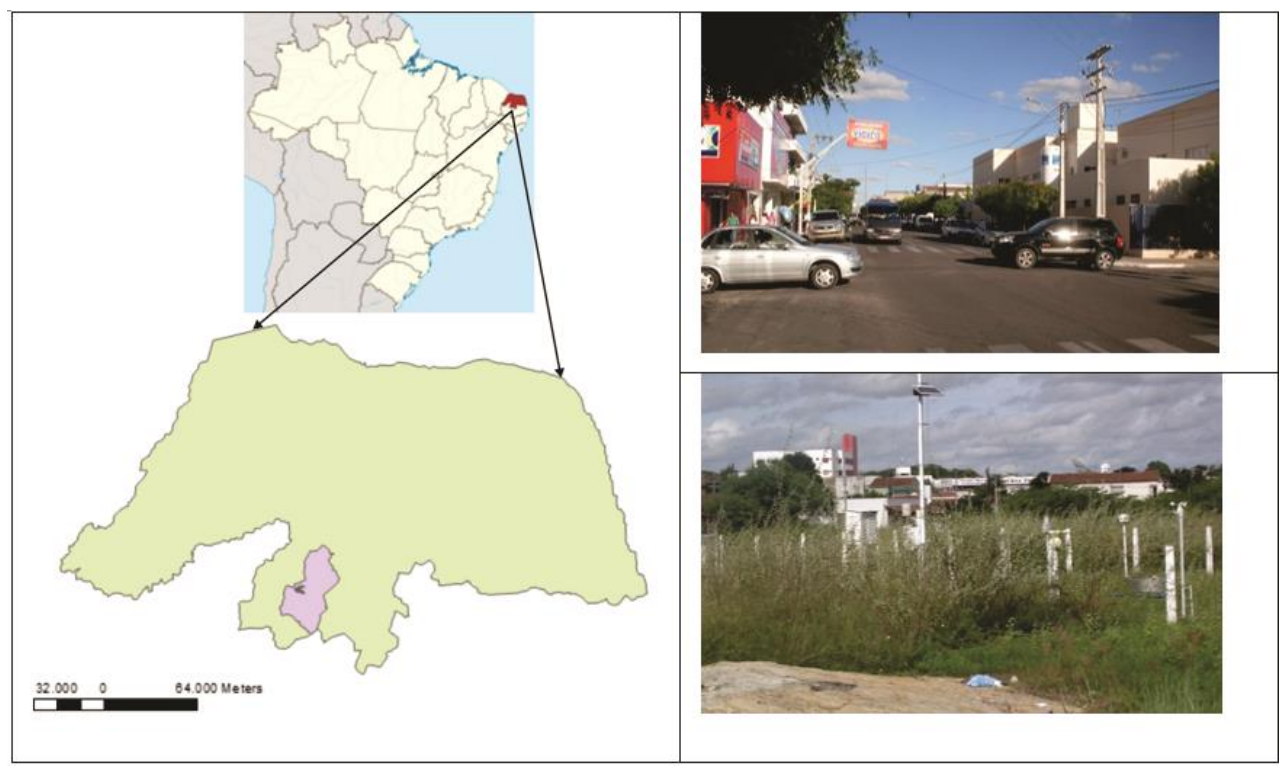

Figura 1 Mapa de localização do município de Caicó no Brasil, com delimitação do estado do Rio Grande do Norte, do município e a sede municipal (esquerda), Avenida Coronel Martiniano (direita superior) e a Estação Climatológica do Seridó (direita inferior)

Fonte: dados da pesquisa.

\section{METODOLOGIA}

Para discutir a relação entre as temperaturas e a questão do conforto térmico humano em Caicó, foram realizados estudos de campo envolvendo a realização de registros fotográficos e a aplicação de três índices de conforto térmico humano cientificamente reconhecidos: Índice de desconforto (ID) o índice de Temperatura Efetiva em função do vento (TEv) e Índice Climático Térmico Universal (ICTU). Para analisar as temperaturas em Caicó, e como elas afetam o conforto da população local, foram adotados os seguintes procedimentos metodológicos.

Primeiramente foram escolhidas as variáveis meteorológicas a serem analisadas: a temperatura do ar, a umidade relativa do ar e a velocidade do vento. Estes valores foram obtidos no Banco de dados do INMET - Instituto Nacional de Meteorologia do Brasil (INMET, 2014) e na Estação Climatológica do Seridó, também pertencente ao INMET, localizada em Caicó (figura 1). De posse dos dados, iniciou-se a análise anual e interanual das temperaturas média, máxima e mínima do ar através da elaboração das normais climatológicas. A série temporal contemplada foi de 15 anos (1996 - 2010), uma vez que a estação climatológica do Seridó só possui dados completos a partir de 1996, tratandose, portanto de uma "normal climatológica provisória". Segundo critérios da OMM, as "normais 
provisórias" podem ser calculadas com observações que se prolonguem por um período de pelo menos dez anos (MMO, 1989 apud OLIVEIRA e VECCHIA, 2010).

Com os dados de temperatura média, máxima e mínima do ar, calculamos a Média Aritmética (x), o Desvio Padrão (S), o Coeficiente de Variação (CV), bem como a tendência pelo método de coeficiente angular do modelo estimado da regressão linear. As retas de tendência linear foram elaboradas segundo a equação estimada (Fórmula.1):

$$
\hat{Y}=b_{0}+b_{1} X_{i},(\text { f.1 })
$$

onde: $\hat{Y}$...é a variável dependente temperatura estimada; $\mathrm{b}_{0} \ldots$... é o coeficiente linear da reta estimada; $b_{1}$...é o coeficiente angular da reta estimada $X_{i}$...é o ano “i”, onde “i” varia de 1996 a 2010 (período de estudo das temperaturas). A regressão linear é um método estatístico que exibe tendências em dados e analisa problemas de previsão e vem sendo amplamente utilizado nos estudos de climatologia, a exemplo dos trabalhos de Gonga et al (2004); Zhou; Ren (2011); White-Newsome et al (2012). Assim, através de fórmulas, foram elaborados tabelas e gráficos para identificar a tendência interanual na variação de temperatura do município de Caicó-RN.

Para analisarmos o clima de Caicó com relação ao conforto térmico humano, foram escolhidos e aplicados três índices cientificamente reconhecidos, a saber: o Índice de stresse por calor excessivo ou Índice de Desconforto - ID (Fórmula.2) e o índice de Temperatura Efetiva em função do Vento - TEv (Fórmula.3), e o Índice Climático Térmico Universal UTCI, calculado diretamente através do site do UTCI calculation: http://www.utci.org/utcineu/utcineu.php. Para o ID aplica-se a fórmula abaixo (fórmula 2) e seu resultado qualitativo pode ser visto na tabela 1 :

$$
\mathrm{ID}=\mathrm{T}-0.55(1-0.01 \mathrm{UR})(\mathrm{T}-14.5)(\text { f. } 2)
$$

onde: ID é o Índice de Desconforto em $\left({ }^{\circ} \mathrm{C}\right)$; $\mathrm{T}$ é a temperatura do bulbo seco $\left({ }^{\circ} \mathrm{C}\right)$; e UR é a umidade relativa (\%). Dessa forma, têm-se os valores do Índice e Desconforto Térmico (ID), o qual é classificado de acordo com a tabela 1 . 


\begin{tabular}{c|c}
\hline ID $\left({ }^{\circ} \mathbf{C}\right)$ & Nível de desconforto térmico \\
\hline $\mathrm{ID}<21,0$ & Não há desconforto \\
\hline $21,0 \leq \mathrm{ID}<24,0$ & Menos de $50 \%$ da população sente desconforto \\
\hline $24,0 \leq \mathrm{ID}<27,0$ & Aprox. $50 \%$ da população sente desconforto \\
\hline $27,0 \leq \mathrm{ID}<29,0$ & A maioria da população sofre desconforto \\
\hline $29,0 \leq \mathrm{ID}<32,0$ & Todas as pessoas sentem estresse severo \\
\hline $\mathrm{ID} \geq 32,0$ & Estado de emergência médica \\
\hline
\end{tabular}

Tabela 1: Classificação do Índice de Desconforto (ID).

Fonte: Matzarakis; Mayer, 1991, com alterações.

Para o TEv aplica-se a fórmula abaixo (fórmula 3) e seu resultado qualitativo pode ser visto na tabela 2:

$\mathrm{TE} v=37-(37-\mathrm{T}) /[0,68-0,0014 \mathrm{UR}+1 /(1,76+1,4 \mathrm{v} 0,75)]-0,29 \mathrm{~T}(1-\mathrm{UR} / 100)(\mathrm{f} .3)$

onde: TE $v$ é temperatura efetiva como função do vento; $\mathrm{T}$ é a temperatura do bulbo seco $\left({ }^{\circ} \mathrm{C}\right) ; \quad$ UR é $\quad$ a $\quad$ umidade relativa do ar em $\quad(\%)$ e v é a velocidade do vento em (m/s) (SUPING et al, 1992). Dessa forma tem-se os valores de TEv que podem ser vistos na tabela 2 .

\begin{tabular}{c|c|c}
\hline TEv $\left({ }^{\circ} \mathbf{C}\right)$ & Sensação Térmica & Grau de estresse fisiológico \\
\hline $\mathrm{TE} v<5$ & Muito Frio (MMFF) & Extremo estresse ao frio \\
\hline $5 \leq \mathrm{TE} v<10$ & Frio (FF) & Extremo estresse ao frio \\
\hline $10 \leq \mathrm{TE} v<13$ & Moderadamente Frio (MFF) & Tiritar \\
\hline $13 \leq \mathrm{TE} v<16$ & Ligeiramente Frio (LFF) & Resfriamento do corpo \\
\hline $16 \leq \mathrm{TE} v<19$ & Pouco Frio (PFF) & Ligeiro resfriamento do corpo \\
\hline $19 \leq \mathrm{TE} v<22$ & Ligeiramente Fresco (LF) & Vasoconstrição \\
\hline $22 \leq \mathrm{TE} v<25$ & Confortável (C) & Neutralidade térmica \\
\hline $25 \leq \mathrm{TE} v<28$ & Ligeiramente Quente (LQ) & Ligeiro suor; vasodilatação \\
\hline $28 \leq \mathrm{TE} v<31$ & Quente Moderado (QM) & Suando \\
\hline $31 \leq \mathrm{TE} v<34$ & Quente (Q) & Suor em profusão \\
\hline $\mathrm{TE} v>34$ & Muito Quente (MQ) & Falha na termoregulação \\
\hline
\end{tabular}

Tabela 2: Classificação do índice de Temperatura Efetiva em função do Vento (TEv).

Fonte: Suping et al, 1992, com alterações.

O Índice Climático Térmico Universal (UTCI) que foi calculado diretamente no site e após o cálculo, os resultados foram conferidos com a resposta da temperatura equivalente, como pode ser visto na tabela 3. 


\begin{tabular}{c|c}
\hline UTCI $\left({ }^{\circ} \mathbf{C}\right)$ & Nível de desconforto térmico \\
\hline $0-10$ & Fraco estresse devido ao frio \\
\hline $10 \leq \mathrm{UTCI}<26$ & Sem estresse térmico \\
\hline $26 \leq \mathrm{UTCI}<32$ & Estresse moderado devido ao calor \\
\hline $22 \leq \mathrm{UTCI}<38$ & Forte estresse devido ao calor \\
\hline
\end{tabular}

Tabela 3: Classificação do Índice Climático Térmico Universal (UTCI).

Fonte: Bröde et al, 2015, com alterações.

\section{RESULTADOS E DISCUSSÃO}

\section{Análise das Temperaturas (1996-2010)}

A região Nordeste do Brasil se caracteriza por apresentar temperaturas elevadas por quase todo o ano, com algumas poucas exceções nas regiões serranas mais elevadas (AB' SABER, 2003). O município de Caicó está localizado no norte da região Nordeste do Brasil numa área de altitudes modestas na depressão sertaneja, afastado do oceano $\sim 200 \mathrm{Km}$ e possui as temperaturas das mais elevadas do Brasil que já é um país de clima predominantemente quente, com exceção das regiões sudeste e sul. A análise da série histórica de 1996 a 2010 mostrou que no município de Caicó as temperaturas são naturalmente bem elevadas durante todos os meses do ano (tab. 4 e fig.2), com média de $\sim 30^{\circ} \mathrm{C}$, média da máxima de $\sim 35^{\circ} \mathrm{C}$ e média da mínima de $\sim 24^{\circ} \mathrm{C}$.

Tabela 4: Média, Desvio Padrão e Coeficiente de Variação das temperaturas máximas e mínimas do ar. Caicó, normal climatológica provisória (1996 - 2010). Fonte: dados da pesquisa.

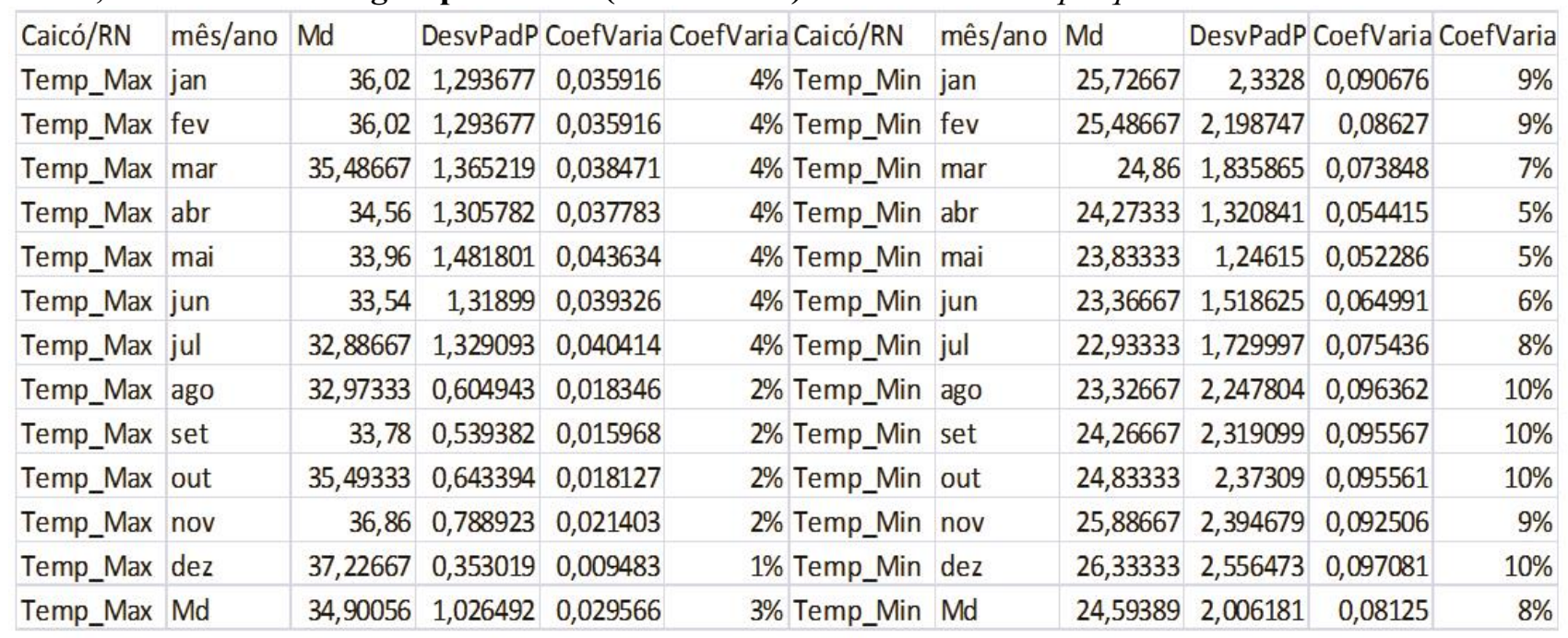




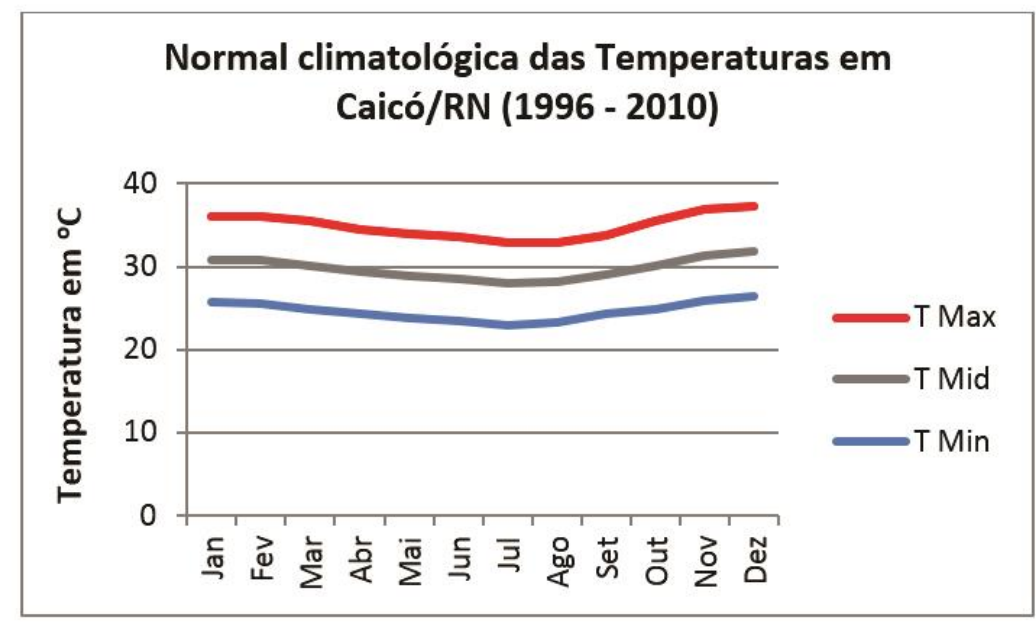

Figura 2: Representação gráfica da temperatura máxima, média e mínima do ar no município de Caicó (1996 - 2010). Fonte: dados da pesquisa.

Em Caicó as diferenças anuais de temperatura são muito sutis e pode-se dizer não há uma estação verdadeiramente fria, conforme explica Ayoade (2007) não há inverno nesta região do globo. As temperaturas mais elevadas ocorrem entre os meses de outubro e fevereiro. Esses meses registram além das mais elevadas temperaturas médias, o período de seca no município e o início da estação chuvosa (a partir de janeiro). As temperaturas mais baixas ocorrem entre os meses de junho e setembro, em consequência da estação do inverno no hemisfério sul. Este padrão serve para as temperaturas máximas, médias e mínimas. Também se percebe que as temperaturas máximas e mínimas não variaram muito no período estudado, apesar de a temperatura mínima apresentar uma maior oscilação. Esses dados podem ser vistos por meio do Coeficiente de Variação (tabela 4).

Em se tratando da variação interanual das temperaturas, é possível afirmar que as temperaturas máximas e mínimas não apresentaram qualquer tendência de aumento ou diminuição. Apesar da afirmação do IPCC de que para o Nordeste e o semiárido brasileiro, o aquecimento das temperaturas médias pode chegar a $3^{\circ} \mathrm{C}$ ainda neste século (IPCC, 2007), os dados de temperatura revelaram estabilidade, onde o coeficiente angular da reta de regressão é estatisticamente igual a zero, mostrando que as temperaturas máximas e mínimas se mantiveram praticamente constantes, havendo maior oscilação das temperaturas mínimas (figuras 3 e 4). 


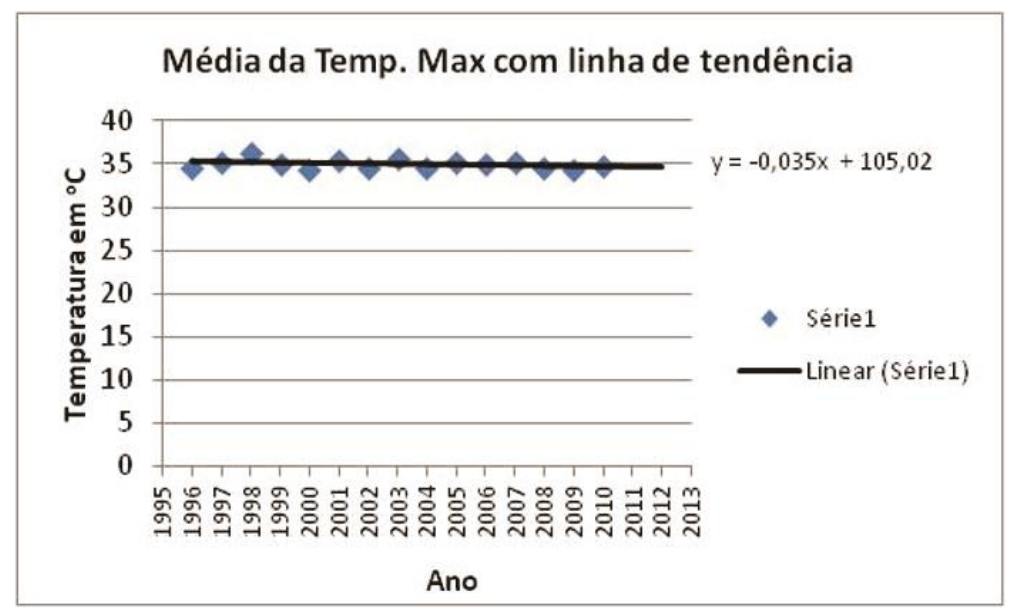

Figura 3: Gráfico de temperatura máxima anual para o município de Caicó-RN (1996-2010) com linha de tendência de previsão para dois períodos. Fonte: dados da pesquisa.

As temperaturas mínimas apresentaram certa oscilação interanual se comparada às temperaturas máximas. Isso pode ser visto nas figuras 3 e 4 e na tabela 4 , onde o Coeficiente de Variação foi de 3\% para as temperaturas máximas e de 8\% para as temperaturas mínimas. Já a análise da regressão resultou em uma reta estimada quase paralela ao eixo horizontal, sendo também não significativa estatisticamente, tal qual a reta das temperaturas máximas (figs. 3 e 4). Merecem destaque os anos de 1999, 2000, 2002 e 2010, que tiveram as temperaturas mínimas anuais mais baixas, inferiores aos $25^{\circ} \mathrm{C}$.

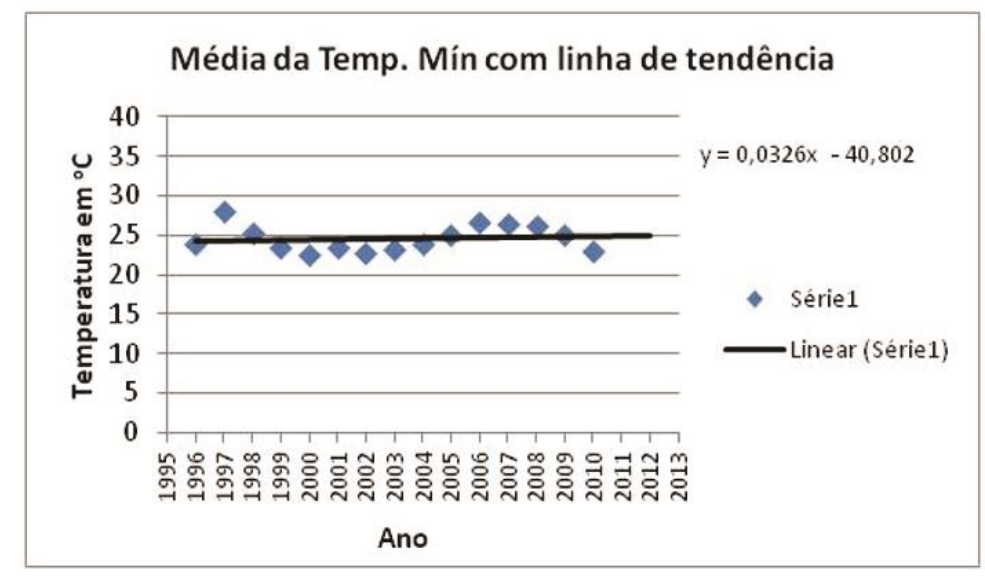

Figura 4: Gráfico de temperatura mínima anual para o município de Caicó-RN (1996-2010) com linha de tendência de previsão para dois períodos. Fonte: dados da pesquisa.

Apesar dos resultados para temperatura mostrarem a estabilidade interanual das mesmas e sabendo que estes dados são legítimos, deve-se destacar que a série analisada cobre um curto período de tempo, uma vez que a estação climatológica do município começou a funcionar no ano de 1996. 


\section{Temperaturas e conforto térmico humano}

Com os resultados obtidos para a variável temperatura no município de Caicó durante o período da normal climatológica provisória (1996 a 2010), realizou-se a aplicação de índices de conforto térmico humano ID, TEv e UTCI. O resultado médio anual para a cidade de Caicó segundo cada índice aplicado foi o seguinte: ID de 28,50, resultando que "a maioria da população sofre desconforto" por causa do calor, TEv de 27,15, resultando em “Clima Ligeiramente Quente - suor e vasodilatação", e UTCI de 28,05 com "estresse moderado devido ao calor". A tabela 5 mostra os resultados quantitativos/qualitativos para Caicó.

Tabela 5: Índices de conforto humano ID, TEv e UTCI aplicados para o município de Caicó série histórica de 1996 - 2010, média anual. Fonte: dados da pesquisa.

\begin{tabular}{|l|l|}
\hline $\begin{array}{l}\text { Índices de conforto } \\
\text { térmico humano }\end{array}$ & $\begin{array}{l}\text { Caicó } \\
\text { Média anual para o período de } \\
\mathbf{1 9 9 6} \text { à 2010 }\end{array}$ \\
\hline ID & $\begin{array}{l}28,50-\text { A maioria da população } \\
\text { Índice de Desconforto desconforto }\end{array}$ \\
\hline TEv & $27,15-$ Ligeiramente Quente LQ, \\
Temperatura Efetiva & Ligeiro Suor, Vasodilatação \\
\hline UTCI & $28,05-$ \\
Indice Climático Térmico & Estresse moderado devido ao calor \\
Universal & \\
\hline
\end{tabular}

Os índices de conforto térmico humano também foram aplicados para cada mês do ano para o período em questão e as médias mensais mostraram que em Caicó anualmente prevalecem meses com estresse térmico devido ao calor. A figuras 5, 6 e 7 trazem em gráfico o comportamento médio anual segundo os índices supracitados. 

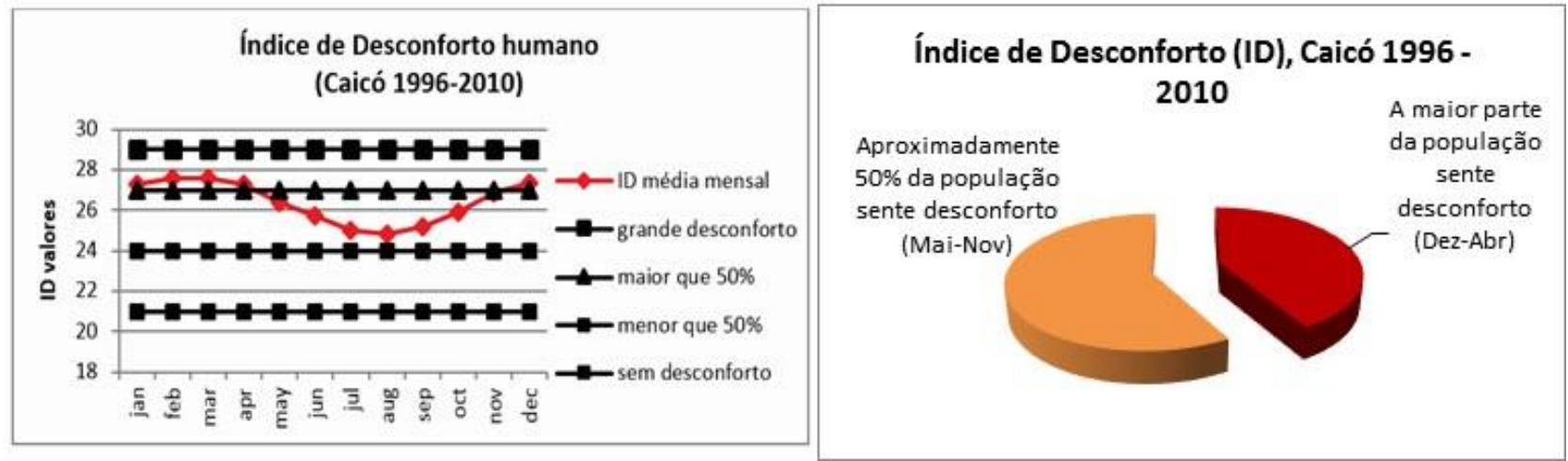

Figura 5: Sensação térmica média anual para Caicó segundo o índice de Desconforto ID (período 1996 2010). Fonte: dados da pesquisa.

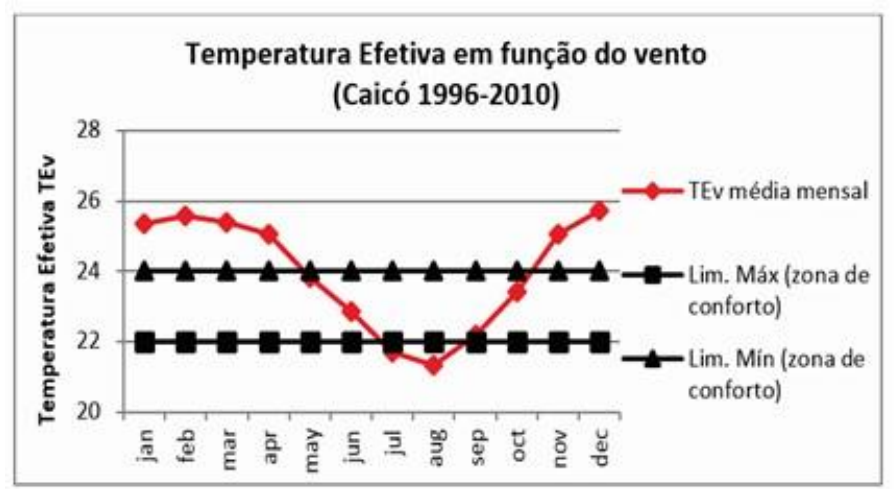
Temperatura Efetiva em função do vento (TEv), Caicó 1996 - 2010

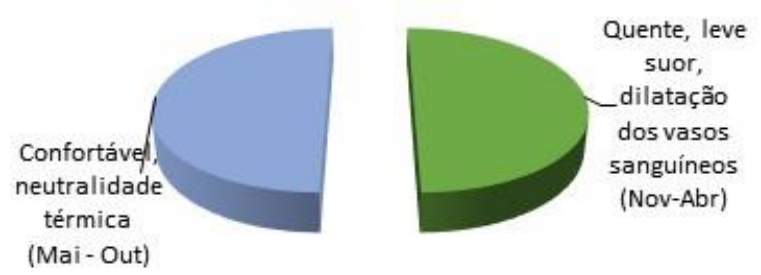

Figura 6: Sensação térmica média anual para Caicó segundo o índice de Temperatura Efetiva TEv (período 1996 - 2010). Fonte: dados da pesquisa.

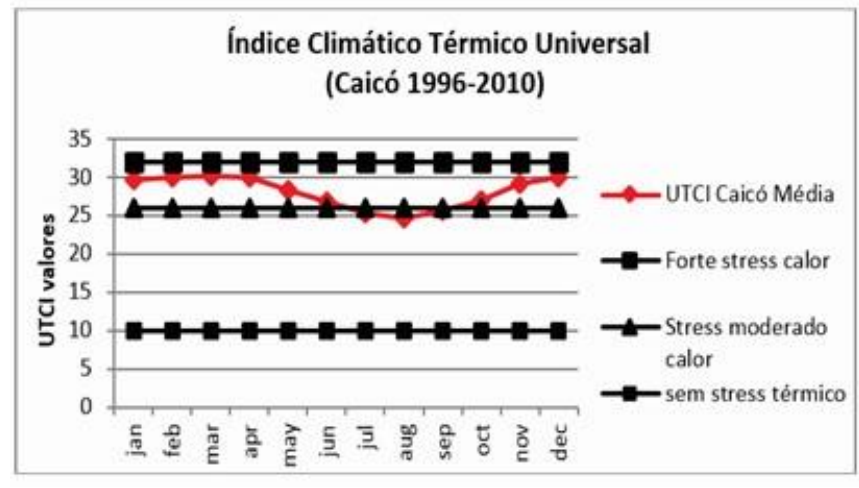

\section{Indice Climático térmico Universal (UTCI), Caicó 1996 - 2010}

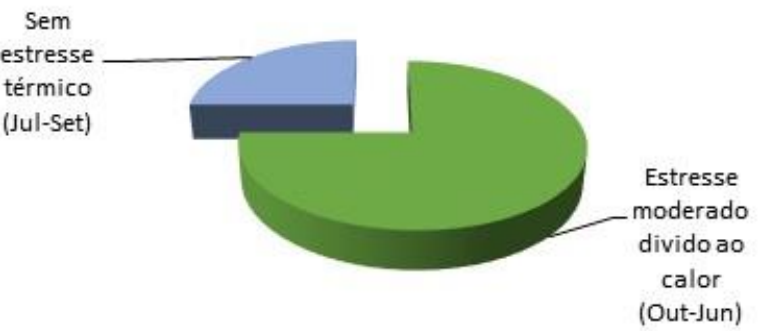

Figura 7: Sensação térmica média anual para Caicó segundo o Índice Climático Térmico Universal UTCI (período 1996 - 2010). Fonte: dados da pesquisa. 
Com os resultados obtidos, podemos afirmar que o município de Caicó possui normalmente temperaturas elevadas (sabendo-se que as temperaturas pouco oscilam anualmente) e que o clima é, de modo geral, desconfortável devido ao calor. Segundo os índices aplicados, os resultados para o ID mostraram que Caicó não apresentou nenhum mês dentro da zona de conforto humano, proporcionando desconforto devido ao calor em todos os meses do ano (ver figura 5). Para a TEv os meses de maio, junho, julho, agosto, setembro e outubro aparecem dentro da faixa de conforto térmico humano, com destaque para agosto que apresenta-se como "ligeiramente frio" (ver figura 6). Segundo o UTCI os meses de julho, agosto e setembro apresentam-se na zona de conforto humano, bem sobre a faixa limite entre a zona de conforto e desconforto moderado devido ao calor (figura 7).

Os resultados mostraram que apenas o ID - Índice de Desconforto colocou Caicó fora da zona de conforto humano devido ao calor durante todos os meses do ano. No entanto, devemos salientar que este índice, apesar de muito usado, não inclui a variável "velocidade do vento", variável esta de grande importância no favorecimento ou não do conforto térmico humano, uma vez que a velocidade do vento é tão importante quanto a temperatura do ar e a umidade relativa na determinação das trocas térmicas entre o organismo e o ambiente (BLAZEJCZYK et al, 2012). Estudos realizados por Santos (2011) e Santos et al (2012) mostraram que a opinião das pessoas com relação às faixas do conforto térmico do Índice de Desconforto (ID) não foram satisfatórias quando aplicadas em zona de clima quente e úmido, isso devido provavelmente a ausência da variável vento que alivia níveis altos de temperatura e umidade nesses lugares. Assim, percebendo a incompatibilidade entre os resultados de conforto humano, conseguidos através de questionário aplicado a população, e àqueles propostos por Giles, Balafoutis (1990), o autor propôs um ajustamento ou adaptação no Índice de Desconforto em seu estudo.

Já os índices utilizados nesta pesquisa que incluíram a variável velocidade do vento (TEv e UTCI) demonstraram que em alguns meses do ano, existe uma condição climática favorável ao conforto humano, devido principalmente à queda de temperatura oriunda da estação de inverno no hemisfério sul e ao aumento da velocidade do vento para o período de inverno e início de primavera. Assim sendo, tanto o TEv quanto o UTCI apontaram situação de conforto térmico para alguns meses do ano que representam a estação de inverno no município de Caicó, diferentemente do ID que não apresentou nenhum período confortável para o município, mas que dos índices utilizados, é o único que não utiliza a variável vento. 


\section{Clima, práticas urbanas e conforto humano: algumas considerações}

Mesmo com as elevadas temperaturas, a falta de adequação arquitetônica, a precária arborização urbana e a realização de podas drásticas em árvores na cidade, só tendem a agravar o desconforto térmico em cidades de clima naturalmente quente. Diversos estudos têm demonstrado que a arborização urbana, além de promover um excelente aspecto paisagístico, promove a redução de temperatura pela cobertura de superfícies refletoras de calor e retém parte da poeira em suspensão (GREY; DENEKE, 1978; JUNIOR; LIMA, 2007; FERREIRA et al, 2012).

Segundo Barbirato (2010 p.86), “a vegetação reduz a temperatura do ar e do solo pelo sombreamento e transpiração, aumentando a umidade próxima. ...da mesma forma, grandes áreas pavimentadas podem gerar desconforto pela alta absorção de radiação próxima ao solo”. No município de Caicó, a área urbanizada é caracterizada por ruas asfaltadas e calçadas, construções de alvenaria, utilizando tijolos e cimento. O acabamento das edificações possui fachadas de vidro e há o uso e abuso do vidro a medida que existe um melhor padrão econômico. Devido a rede elétrica, a arborização urbana é problemática, no sentido de que se utilizam espécies arbóreas de pequeno e médio porte que não propiciam grandes áreas de sombreamento além de que são realizadas, frequentemente, podas drásticas nas árvores existentes. A figura 8 (a, b, c, d, e \& f) mostra as fachadas de vidro dos edifícios das principais ruas da cidade de Caicó e algumas das inúmeras podas severas realizadas no ano de 2014. 


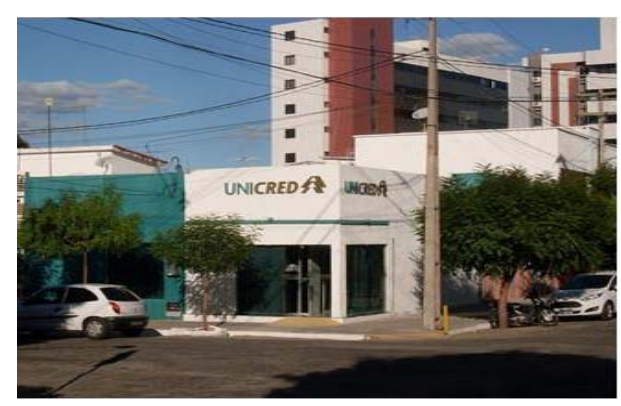

(a)

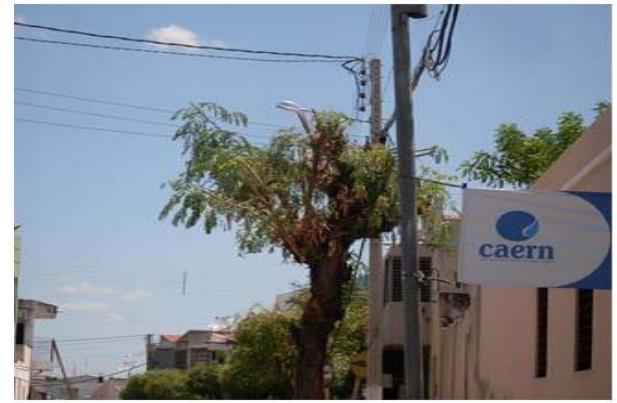

(c)

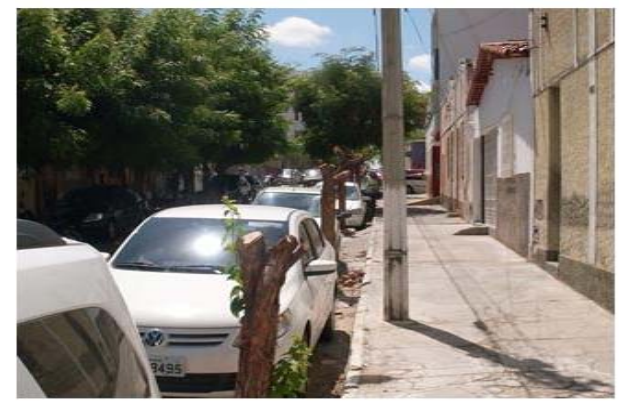

(e)

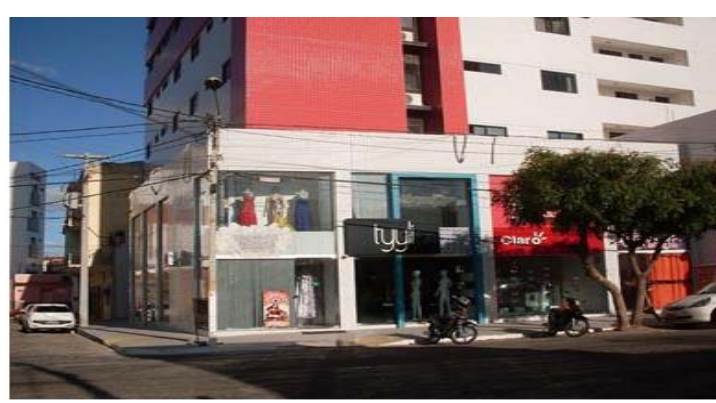

(b)

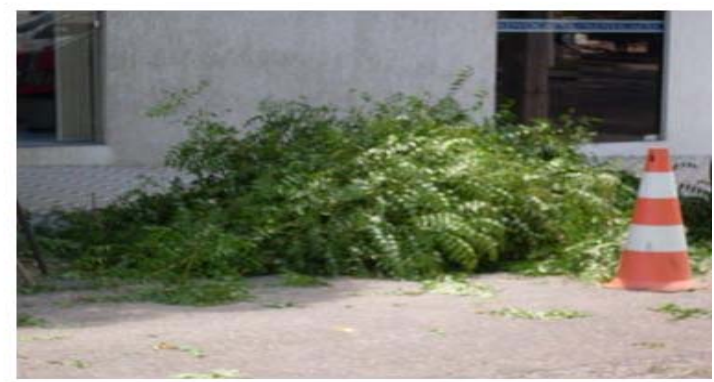

(d)

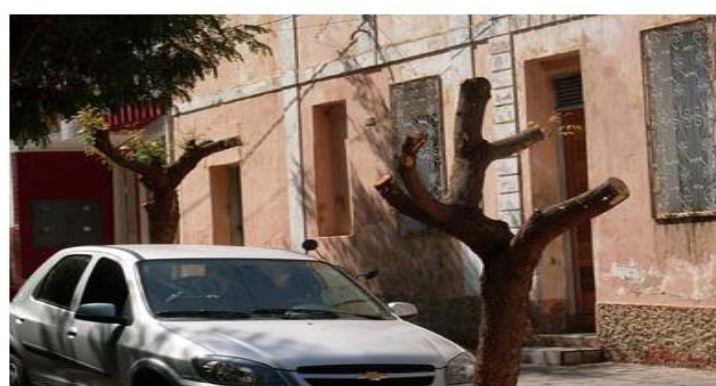

(f)

Figura 8 (a, b, c, d, e \& f): Fachadas de vidro nas construções e podas drásticas realizadas na altura do poste de iluminação pública, ano de 2014. Fonte: dados da pesquisa.

O vidro, sinônimo de luxo na arquitetura brasileira, mostra-se bastante inadequado em cidades de clima semiárido quente como o de Caicó. Mesmo assim, usa-se com frequência o vidro nas fachadas dos departamentos e por vezes se coloca uma lona sobre o vidro durante as horas mais quentes do dia. Como o vidro favorece o efeito de estufa, tem-se que investir fortemente na climatização interna desses ambientes, através do uso de condicionadores de ar, aumentando assim o consumo de energia elétrica nos estabelecimentos comerciais e residenciais.

Em lugares de clima quente e seco o sombreamento das ruas e estabelecimentos deve ser tratado com prioridade na urbanização da mesma forma que o controle do vento diurno e noturno pode favorecer o conforto humano sem que se tenha que recorrer à climatização artificial (ROMERO, 2013). 
A arborização planejada, com espécies arbóreas produtoras de grandes áreas sombreadas também favorecem a amenização das temperaturas, promovendo uma microclimatização mais adequada ao clima local. As cidades que crescem segundo os paradigmas da urbanização globalizada tendem e expor seus habitantes a situações de desconforto térmico por falta de adequação arquitetônica e paisagística, para além das tendências de aquecimento climático global.

\section{CONSIDERAÇÕES FINAIS}

Neste trabalho, foi possível constatar que no município de Caicó, a temperatura do ar é naturalmente muito elevada, com média de $\sim 30^{\circ} \mathrm{C}$, máxima de $\sim 35^{\circ} \mathrm{C}$ e mínima de $\sim 24^{\circ} \mathrm{C}$, estando Caicó, grande parte do ano, no limite da zona de conforto humano devido ao calor excessivo, como foi confirmado através da aplicação dos índices de Conforto humano ID, TEv e UTCI. No entanto, a análise de regressão para o período de 1996-2010 mostrou que as temperaturas máxima e mínima do ar não exibiram qualquer tendência ao aumento ou diminuição, uma vez que a linha de tendência exibiu uma reta paralela ao eixo horizontal, sendo por tanto, não significativa estatisticamente.

Mesmo apresentando estabilidade na série histórica da temperatura do ar, a análise de índices de conforto humano mostrou que para o Índice de Desconforto (ID) Caicó não apresenta nenhum mês dentro da zona de conforto humano, apresentando desconforto devido ao calor em todos os meses do ano. Para o índice de Temperatura Efetiva em função do Vento (TEv) os meses de maio, junho, julho, agosto, setembro e outubro aparecem dentro da faixa de conforto térmico humano, com destaque para agosto que apresenta-se como "ligeiramente frio". Segundo o Índice Climático Térmico Universal (UTCI) os meses de julho, agosto e setembro apresentam-se na zona de conforto humano. O ID trouxe os resultados mais rigorosos quanto às condições de conforto para o município, visto que este índice não considera a variável vento, variável esta que é muito importante na avaliação do conforto térmico humano. Assim sendo, sugere-se, para lugares quentes a utilização de índices que considerem o vento.

Os índices de conforto térmico, apesar de serem classificações climáticas que admitem muita subjetividade por envolver questões ligadas à opinião humana, estão presentemente sendo utilizados por vários serviços meteorológicos de todo o mundo, e podem ser avaliados facilmente por usuários com base na necessidade de descrever a potencial carga de calor e os processos de termorregulação à que estão submetidos (Blazejczyk, 2012), sendo de grande importância tanto para estudos climáticos e biometeorológicos quanto para estudos voltados ao planejamento espacial, arquitetura e urbanismo, 
por mais que apresentem complexidades por razão da carga de subjetividade implícita. Em um mundo cada vez mais urbanizado estes índices deverão ser mais empregados e aprimorados para inferir a situação térmica das cidades com relação ao conforto humano e a qualidade de vida. A falta de adequação arquitetônica, com uso do vidro em muitas edificações e a precária arborização urbana atrelada a realização de podas drásticas das árvores, a orientação das ruas em direção poente só tendem a agravar o desconforto térmico em lugares naturalmente quentes, como o município aqui estudado, Caicó. Sob estas circunstancias, se incluirmos à situação térmica encontrada em Caicó durante este estudo, qualquer possibilidade de aumento de temperatura do ar por consequência do aquecimento global ou mesmo por consequência de alterações no uso e ocupação do solo ao nível local, a população poderá vir a enfrentar problemas sérios de desconforto térmico que poderão interferir na qualidade de vida e até na saúde dos cidadãos locais devido ao calor excessivo.

AGRADECIMENTOS: Ao Instituto Nacional de Meteorologia (INMET) por conceder os dados meteorológicos desta pesquisa.

\section{REFERÊNCIAS}

AB'SABER, Aziz Nacib. Caatingas: o domínio dos sertões secos. In Os domínios de natureza no Brasil: Potencialidades paisagísticas. Editado por Aziz Nacib Ab'saber. $6^{\mathrm{a}}$ Ed. 83-100, São Paulo: Ateliê Editorial, 2003.

ABDEL-GRANY, A.M., Al-Helal, I.M., Shady, M.R. Human thermal comfort and heat stress in an outdoor urban Arid environment: a case study. Advances in Meteorology. v.2013, ID 6, 7 pages. , 2013. doi: http://dx.doi.org/10.1155/2013/693541

ASHRAE - American Society of Heating, Refrigerating and Air Conditioning Engineers, 2009. Fundamentals. ASHRAE (1997) Handbook Fundamentals Volume, Chap.8. Thermal Comfort, 8.18.28. Inch-Pound Edition: Atlanta - GA, 2009.

AYOADE, John Olaniyi. Introdução à Climatologia para os Trópicos. Traduzido por Santos, Maria Juraci Zani dos. 12 Ed. Rio de Janeiro: Bertrand Brasil, 2007.

BARBIRATO, Gianna Melo. A importância da abordagem climática no planejamento urbano., In Atmosfera e sociedade: a ação da atmosfera sobre os seres vivos e a qualidade de vida humana. Editado por Oliveira, José Clênio Ferreira de. 75-90. Maceió: EDUFAL, 2010. 
BITTENCOURT, Leonardo Salazar. O clima como formador do repertório arquitetônico. In Atmosfera e sociedade: a ação da atmosfera sobre os seres vivos e a qualidade de vida humana. Editado por Oliveira, José Clênio Ferreira de. 103-122. Maceió: EDUFAL, 2010.

BLAZEJCZYK, Krzysztof; Epstein, Yoram; Jendritzky, Gerd; Staiger, Henning; Tinz, Birger. Comparison of UTCI to selected thermal indices. International Journal of Biometeorology. 56:515-535, 2012. doi: 10.1007/s00484-011-0453-2

BRASIL. Instituto Brasileiro de Geografia e Estatística. IBGE Estados. Acesso em 20 de Outubro de 2013. http://www.ibge.gov.br/estadosat/perfil.php?sigla $=$ rn

BRASIL. Ministério do Desenvolvimento Agrário. Sistema de Informações Territoriais. Índices de Desenvolvimento do Seridó - RN., Acesso em 10 de Maio de 2013.

$\mathrm{http}: / /$ sit.mda.gov.br/territorio.php?ac $=$ buscar \&base $=1 \&$ abr $=$ uf\&regiao $=\& u f=R N \&$ territorio $=76 \&$ te $\mathrm{ma}=6$.

BRÖDE, Peter; Fiala, Dusan; Blazejczyk, Krzysztof; Epstein, Yoram; Holmés, Ingvar; Jendritzky, Gerd; Kampmann, Bernhard; Richards, Mark; Rintamaki, Hannu; Shitzer, Avraham; Havenith, George. 2014. Calculating UTCI equivalent temperatures. $13^{\text {th }}$ International Conference on environmenteal Ergonomics, Boston USA, 2009. Acessed Nov 2014.

http://www.utci.org/utci_poster.pdf

EPSTEIN, Y., Moran, D.S. Thermal comfort and the heat stress indices. Industrial Health. July, 44 (3): 388-398, 2006 doi: http://doi.org/10.2486/indhealth.44.388

FERREIRA, Cássia de C. Martins; Assis, Débora Couto de; Pimentel, Franciele de Oliveira; Oliveira, Daiane Evangelista de. O estudo do microclima gerado por praças em relação aos seus arredores na cidade de Juiz de Fora-MG. Revista GeoNorte, Edição Especial 2 (5): 496 - 508, 2012.

GILES S, B. D.; Balafoutis S, C. H. 1990. The Greek heatwaves of 1987 and 1988. International Journal of Climatology, 10 (5): 505-517, 1990.

GONGA, Dao-Yi, Shia, Pei-Jun and Wangb, Jing-Ai. 2004. Daily precipitation changes in the semiarid region over northern China. Journal of Arid Environments. 59: 771-784. Accessed May 02, 2013. doi: 10.1016/j.jaridenv.2004.02.006.

GREY, Gene W., and Deneke, Frederick J. Urban forestry. New York: John Wiley, 1978.

INMET. Normais climatológicas do Brasil 1961-1990. Editado por Andrea Malheiros Ramos, Luiz André Rodrigues dos Santos, Lauro Tadeu Guimarães Fortes. Brasília, DF: INMET, 2009.

INMET. BDMET: Banco de dados Meteorológicos. Acesso em 12 de Abril de 2012. http://www.inmet.gov.br/.

IPCC. INTERGOVERNMENTAL PANEL ON CLIMATE CHANGE. 2007. Mudança do Clima 2007: a Base das Ciências Físicas. IPCC/ONU, versão em português: iniciativa da Ecolatina 1. Acesso em 01 de Dezembro de 2007. http://www.natbrasil.org.br/Docs/ipcc_2007.pdf 
IPCC. INTERGOVERNAMENTAL PANEL ON CLIMATE CHANGE. Climate Change 2013: The Physical Science Basis. IPCC WGI, AR5. Acesso em 27 de Maio de 2013. http://www.climatechange2013.org/

JENDRITZKY, Gerd., Dear, Richard de., Havenith, George. UTCI - Why another thermal Index? International Journal of Biometeorology. 56: 421-428, 2012. doi: 10.1007/s00484-011-0513-7

JUNIOR, José H. de Aguirre and Lima, Ana Maria L. Pereira. 2007. Uso de árvores e arbustos em cidades brasileiras. Revista SBAU, Piracicaba, 2 (4): 50-66, 2007.

MAKOKHA, George Lukoye. Variations of the Effective Temperature Index (ET) in Kenya. GeoJournal. April, 44 (4): 337-343, 1998. doi: 10.1023/A:1006880509054

MARENGO, José A., Nobre, Carlos A., Chou, Sin Chan, Tomasella, Javiar, Sampaio, Gilvan, Alves, Lincoln M., Obregon, Guillermo O., Soares, Wagner R., Betts, Richard and Kay, Gillian. Riscos das mudanças climáticas no Brasil: análise conjunta Brasil - Reino Unido sobre os impactos das mudanças climáticas e do desmatamento na Amazônia. INPE/Met Office, 2011.

MATZARAKIS, Andreas and Mayer, Helmut. 1991. The extreme heat wave in Athens in July 1987 from the point of view of human biometeorology. Atmospheric environment. 25b (2): $203-211$. Accessed May 03, 2014. doi: 10.1016/0957-1272(91)90055-J

MONTEIRO, Carlos Augusto de Figueiredo.; Mendonça, Francisco. Clima Urbano. São Paulo: Contexto, 2003

NEDEL, Anderson S.; Coelho, Micheline de Sousa.; Gonçalves, Fabio Luiz Teixeira. Comparative analysis of different human thermal comfort indexes in São Paulo city and their relationship with respiratory morbidity. Proceedings of 8 ICSHMO, Foz do Iguaçú, Brazil, April 24 -28, INPE, p.675-677, 2006.

OKE, Tim. Boundary layer climates. New York: Routledge, 1996.

OLIVEIRA, Marcos José de, and Vecchia, Francisco. 2010. Elaboração de normais climatológicas: Caracterização e tendências de temperatura em Itirapina - SP, Brasil., Trabalho apresentado no XVI Congresso Brasileiro de Meteorologia. Pará, Belém: September, 13 - 17, 2010.

ONGOMA, Victor; Muthama, John Nzioka. A Review and Assessment of Applicability of the Heat Stress Indices in Kenyan Weather Forecast. Open Journal of Atmospheric and Climate Change, 1 (1): 17-22, 2014.

POLYDOROS, T.; Cartalis, C. Assessing thermal risk in urban areas - an application for the urban agglomeration of Athens. Department of Environmental Physics, University of Athens, University Campus, Build PHYS-V, Athens 15784 Disponible in http:/www.aivc.org/sites/default/files/198.1370023063full.pdf Acessed in 22/12/2015.

ROMERO, Marta Adriana Bustos. Princípios bioclimáticos para o desenho urbano. Brasília: Editora Universidade de Brasília, 2013. 
SANTANA, Marcos Oliveira. Atlas das áreas susceptíveis à desertificação do Brasil. Brasília: MMA - Ministério do Meio Ambiente, 2007.

SANTOS, J. S. dos. Campo térmico urbano e a sua relação com o uso e cobertura do solo em cidade de clima tropical úmido. Tese de Doutorado, Programa de Pós-graduação em Recursos Naturais, Universidade Federal de Campina Grande (UFCG), 110p, 2011.

SANTOS, J. S. dos; Silva, V. de P. R. da; Silva, E. R. da; Araújo, L. E. de; Costa, A. D. L. Campo Térmico Urbano e a sua Relação com o Uso e Cobertura do Solo em Cidade Tropical Úmida.

Revista Brasileira de Geografia Física, (03): 540-557, 2012.

SANTOS, Wially Roger Tavares and Melo, Maria Luciene Dias de. Índices de conforto e desconforto térmico humano segundo os cenários climáticos do IPCC. In Atmosfera e sociedade: aspectos multi e interdisciplinares da meteorologia. Editado por Oliveira, José Clênio Ferreira de. 153-163. Maceió: EDUFAL, 2011.

SETTE, Ribeiro. Interações entre o clima, o tempo e a saúde humana. Interfacehs: revista de saúde, meio ambiente e sustentabilidade. Agosto, 6 (2): 37 - 50, 2011.

SOUZA, Débora Moreira de, and Nery, Jonas Teixeira. 2012. "O Conforto térmico na perspectiva da Climatologia Geográfica.”, Geografia (Londrina). Mai/Ago, 21 (2): 65-83.

SUPING, Zhang., Guanglin, Meng., Yanwen, Wang, and Ji, Li. 1992. Study of the relationships between weather conditions and the marathon race, and os meteorotropic affects on distance runners. International Journal of Biometeorology. v.36: 63 - 68. January 25, 2014. doi: 10.1007/BF01208915

TAHA, Haider. 1997. Urban climates and heat islands: albedo, evapotranspiration, and anthropogenic heat. Energy and Buildings. 25: 99-103. Accessed November 01, 2013. doi: 10.1016/S0378-7788(96)00999-1

WHITE-NEWSOME, Jalonne L., Sánchez, Brisa N., Jolliet, Olivier, Zhang, Zhenzhen, Dvonch, Timothy J., and O'neill, Marie S. 2012. Climate change and health: Indoor heat exposure in vulnerable populations. Environmental Research. Jan. 112: 20 - 27. Accessed September 02, 2013. doi: 10.1016/j.envres.2011.10.008

WINSLOW, CEA; Herrington, LP; Gagge, AP. Physiological reactions oh the human body to varying environmental temperatures. Journal of Physiology. v. 120, September 1, 1937.

WOJTACH, Barbara. UTCI Calculator. Institute of Meteorology and Hydrology, Warsaw, Poland. Disponível em: http://www.utci.org/utcineu/utcineu.php. Acesso em 03 de Abril de 2014.

YOUSIF, Tawhida, A.; Tahir, Hisham M. M. Application of Thom's Thermal Discomfort Index in Khartoum State, Sudan. Journal of Forest Products \& Industries. 2 (5): 36-38, 2013.

ZHOU, Yaqing, and Ren, Guoyu. 2011. Change in extreme temperature event frequency over mainland China, 1961-2008. Climate Research. 50: 125 - 139. Accessed January 10, 2013. doi: $10.3354 / \mathrm{cr} 01053$ 
3.2 Artigo 2 Análise higrotérmica do município de Caicó/RN/Brasil

Autoria: Rebecca Luna Lucena; Ercília Torres Steinke

\title{
Resumo
}

O objetivo principal deste trabalho foi elaborar um diagnóstico higrotérmico do município de Caicó aplicando índices de conforto térmico humano para onze pontos no município, sendo dez em área urbanizada e um numa área com aspecto rural. Para a realização deste trabalho foram utilizados termohigrômetros automáticos datalogger Akso AK170, que foram distribuídos pela malha urbana coletando dados horários de temperatura do ar e umidade relativa do ar no período de um mês. Os termômetros foram dispostos considerando as características geográficas e a estrutura arquitetônica da cidade. A partir da coleta dos dados, realizaram-se análises estatísticas e três índices de conforto humano foram aplicados, Índice de Desconforto (ID), índice de Temperatura Efetiva (TE), e o Índice de Temperatura e Umidade ITU), no intuito de se investigar quais os locais mais confortáveis/desconfortáveis num município que possui clima naturalmente quente.

Palavras-chave: clima urbano, análise higrotérmica, Caicó/RN, índices de conforto térmico humano

\begin{abstract}
The main purpose of this article is to develop an urban climate diagnosis of the city of Caicó, by analyzing air temperature and relative humidity and applying human thermal comfort indices for eleven points of town, ten of which located in the urban area and one in the rural area. The data was collected using automatic thermo-hygrometers datalogger Akso AK170, which were distributed by the urban area collecting temperature and humidity data for the period of one month. The thermometers were installed taking into consideration the geographical features and the architectural structure of the city. Statistical analysis considered three human comfort indices, Discomfort Index (DI), Effective Temperature (ET), and Humidity Temperature Index (HTI) in order to discover the most comfortable and uncomfortable locations of this naturally hot weathered town.
\end{abstract}

Key-words: urban climate, hygrothermal analysis, Caicó / RN, human thermal comfort indices 


\section{Introdução}

Os estudos de clima urbano vêm sendo realizados por todo o mundo desde algumas dezenas de anos, tendo sido mais expressivos após a revolução industrial, com foco, entre outras abordagens, na análise térmica e na poluição atmosférica nas cidades industrializadas. Os estudos de Monteiro (1976), Landsberg (1981), Lombardo, (1985), Taha (1997), Gartland (2010), são alguns exemplos de trabalhos nacional e internacionalmente reconhecidos, onde já se apontava uma "atmosfera diferente" sobre e no ambiente urbanizado. No Brasil, os estudos do clima urbano ganharam notoriedade através dos trabalhos de Carlos A. F. Monteiro e de Magda A. Lombardo quando da publicação dos seus trabalhos “Teoria e Clima Urbano" e "Ilhas de Calor das Metrópoles", respectivamente (ZAVATTINI, 2004). A tese de Carlos A. F. Monteiro trouxe uma proposta de delimitação para os estudos do clima urbano focados em três distintos campos, conforme afirma Monteiro e Mendonça (1976; 2003): o campo hídrico-meteórico, abarcando os meteoros de impacto; o campo térmico-higrométrico, com abordagem nas condições térmicas e de conforto humano; e o campo físico-químico, trabalhando com aspectos relacionados à poluição do ar. Os três campos, muito importantes do ponto de vista humano, são abordados sob uma mesma perspectiva: a de que na área urbanizada as condições atmosféricas divergem de seu entorno, ou seja, existe no ambiente urbano uma atmosfera diferente que mesmo vinculada aos sistemas sinóticos de grande e média escala, diverge desses sistemas maiores por apresentar peculiares oriundas às características do sítio urbano. Nas grandes metrópoles, estudos comprovam que, de fato, as características atmosféricas se mostram distintas daquelas das áreas de entorno com aspectos rurais e florestais. O que, de um modo geral, pode ser atribuído ao clima urbano são as seguintes características: uma área central mais aquecida que o entorno "ilha de calor"; uma atmosfera mais poluída que o entorno; impactos pluviométricos intensos mais catastróficos que o entorno (TAHA, 1997, MONTEIRO; MENDONÇA 2003, GARTLAND, 2010). Outros estudos ainda trazem mudanças no teor de umidade e na direção e velocidade dos ventos quando se compara o sitio urbano com áreas naturais ou até rurais.

É sabido que existe uma maior diferença entre o ambiente urbanizado e o seu entorno quanto maior e mais modificada for a natureza do sitio urbano. Landsberg (1956) já relatava que mesmo uma rua é capaz de produzir um próprio clima urbano, assim sendo, não apenas às metrópoles se torna importante estudos dessa natureza, mas também em cidades de médio e pequeno porte. 
Em se tratando do campo térmico nos estudos de clima urbano, para as cidades localizadas nas zonas tropicais, tais estudos se tornam ainda mais relevantes, uma vez que as condições climáticas naturais já tendem ao calor por natureza latitudinal, podendo as ilhas de calor gerar forte desconforto à população local.

Diante desse contexto, o objetivo principal dessa investigação foi elaborar um diagnóstico do comportamento térmico e higrométrico da malha urbana do município de Caicó analisando dados de temperatura do ar e umidade relativa do ar e aplicando índices de conforto térmico humano para 11 pontos da cidade distribuídos estilo malha urbana. A escolha dos pontos foi feita a partir de estudos que tratam das características geográficas, topográficas, arquitetônicas da cidade, comparando diferentes pontos dentro de Caicó e tendo um ponto localizado em área periférica com aspecto rural, para fins comparativos.

\section{Metodologia}

\section{Escolha e características gerais da área de estudo}

A escolha da área de estudo se deve à importância da cidade para a região e também por suas condições geográficas e climáticas. Caicó é um município de pequeno porte, com população de 63.000 habitantes e uma área menor que $1.500 \mathrm{~km}^{2}$. É o município mais importante da microrregião do Seridó tanto paraibano quanto o norte-rio-grandense. Está localizado na depressão sertaneja, área deprimida do Nordeste setentrional do Brasil, onde segundo Ab' Saber (2003), representa o "verdadeiro semiárido", as depressões interplanálticas recobertas de vegetação Caatinga, rica em espécies xerófitas, com solos pedregosos e formações testemunhas de inselbergs. Por se situar em baixa latitude $\sim 06^{\circ}$ Sul, com uma altitude média de 161 metros, além de estar a aproximadamente $200 \mathrm{~km}$ de distância do mar e devido aos padrões de circulação atmosférica atuantes, tais condições conferem a Caicó um tipo climático quente e semiárido.

A temperatura média anual do município é de $30^{\circ} \mathrm{C}$, com média da máxima de $35^{\circ} \mathrm{C}$ e média da mínima de $24,5^{\circ} \mathrm{C}$ (LUCENA et al, 2016). A média pluviométrica anual é de $659 \mathrm{~mm}$ com forte variabilidade interanual no total de chuvas (Lucena et al, 2012; Lucena et al, 2013; 2016). O clima semiárido onde está inserido é produto das taxas de precipitação em combinação com a elevada insolação (média de 3.800 horas/ano) que gera alta evaporação das águas (média de 3000 mm anuais), 
promovendo déficit hídrico na maior parte do ano. A Figura 1 destaca a localização do município de Caicó no Brasil e no estado do Rio Grande do Norte, o aspecto de sua paisagem natural com o açude Itans ao fundo e a área urbana onde se pode observar a serra de São Bernardo ao fundo.
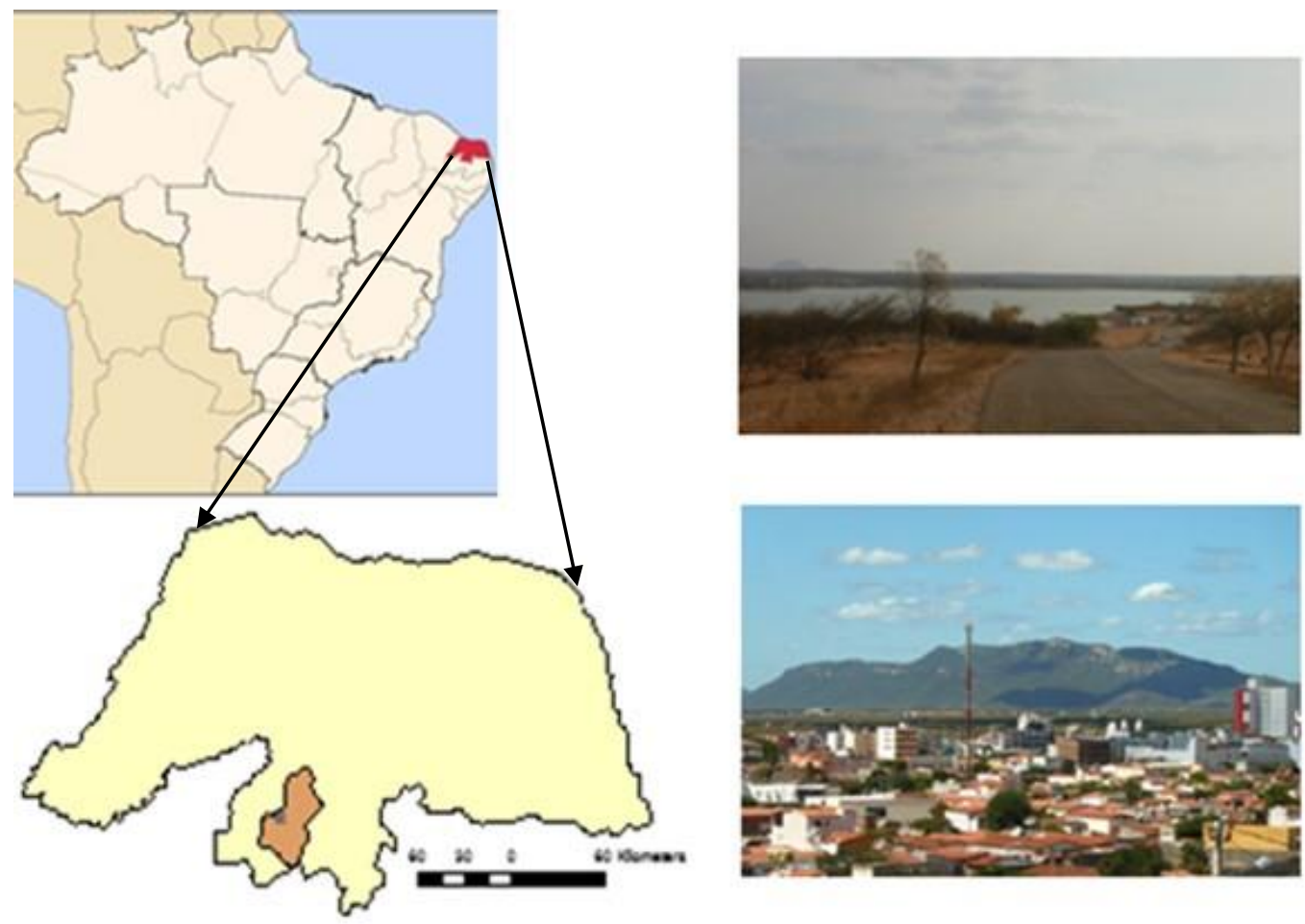

Figura 1 Localização do município de Caicó no Brasil (esquerda), aspecto da paisagem natural com o açude Itans (direita superior) e vista da paisagem urbana localizada na depressão sertaneja com a serra de São Bernardo ao fundo (direita inferior).

Fonte: cidade-Brasil, 2015; arquivo dos autores.

\section{Escolha de pontos para disposição dos equipamentos}

Sob condições de clima semiárido quente se desenvolveu o município de Caicó, que seguiu o mesmo ritmo da urbanização brasileira que teve grande impulso a partir da década de 1950 (Faria, 2011). Logo, a expansão urbana se ampliou e hoje Caicó possui uma região central, com várias ruas asfaltadas e calçadas, com forte densidade de construções, que diminui à medida que nos afastamos do centro comercial. Os bairros mais periféricos ainda apresentam ruas de barro e menor densidade de construções.

Foram escolhidos 11 pontos do município para coleta de dados meteorológicos, para se analisar o comportamento de clima urbano de Caicó, conforme características geográficas e arquitetônicas 
baseadas em leituras, principalmente aquelas que têm como fonte o trabalho da professora M. Romero (2013) "princípios bioclimáticos para o conforto humano". A Figura 2 destaca, na imagem de satélite, os pontos onde foram instalados os equipamentos e as características desses pontos estão descritas resumidamente na Tabela 1. 
Universidade de Brasília

GEA - Departamento de Geografia PPG/GEA- Programa de Pós-Graduação

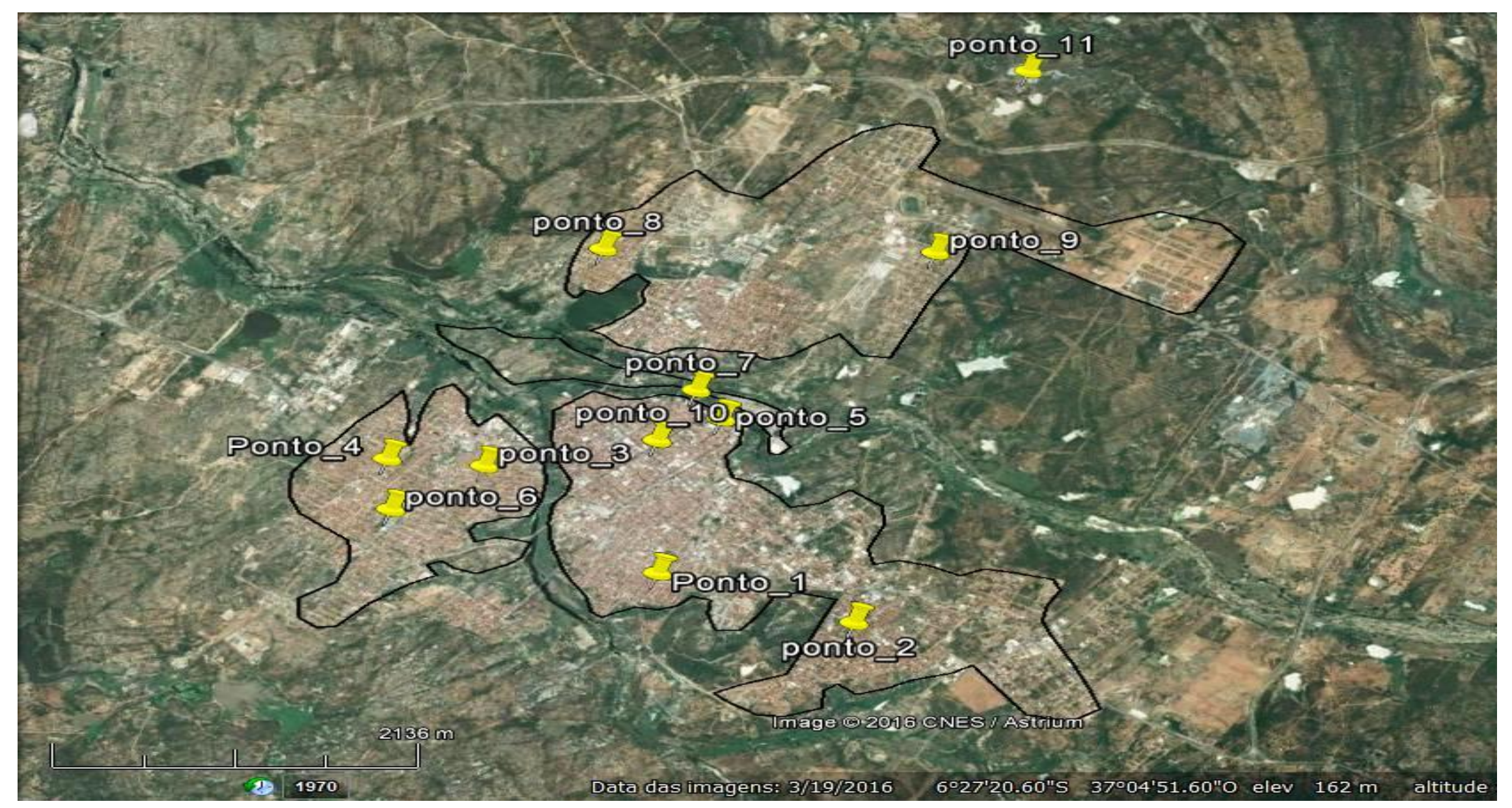

Figura 2 Malha urbana de Caicó com os 11 pontos escolhidos para coleta.

Fonte: trabalhada no Google Earth. Data da imagem 19/03/2016 
Universidade de Brasília

GEA - Departamento de Geografia PPG/GEA- Programa de Pós-Graduação

Tabela 1 Nome do ponto, coordenadas geográficas, altitude e característica principais.

\begin{tabular}{|c|c|c|c|c|}
\hline Ponto & Nome/referência & Coordenadas & Altitude & Características principais \\
\hline 1 & Nascente (Paraíba) & $\begin{array}{l}06^{\circ} 28^{\prime} 17^{\prime}, \\
37^{\circ} 05^{\prime} 41^{\prime \prime} \mathrm{O}\end{array}$ & 185 & Rua larga calçada, sem árvores, posição nascente \\
\hline 2 & Poente (Coacal) & $\begin{array}{l}06^{\circ} 28^{\prime} 28^{\prime}, \mathrm{S} \\
37^{\circ} 05^{\prime} 01^{\prime}, \mathrm{O}\end{array}$ & 192 & Rua larga calçada, sem árvores, posição poente \\
\hline 3 & Vale (João XXIII) & $\begin{array}{l}06^{\circ} 27^{\prime} 49^{\prime \prime} \mathrm{S} \\
37^{\circ} 06^{\prime} 18^{\prime}, \mathrm{O}\end{array}$ & 164 & Rua calçada, fundo de vale, posição sul \\
\hline 4 & Alto pedra (Picanço) & $\begin{array}{l}06^{\circ} 27^{\prime} 48^{\prime}, \mathrm{S} \\
37^{\circ} 06^{\prime} 37^{\prime}, \mathrm{O}\end{array}$ & 192 & Ponto elevado, topo de encosta sobre granito, posição nascente \\
\hline 5 & Rua estreita (Centro) & $\begin{array}{l}06^{\circ} 27^{\prime} 32^{\prime \prime}, \mathrm{S} \\
37^{\circ} 05^{\prime} 33^{\prime \prime} \mathrm{O}\end{array}$ & 175 & $\begin{array}{l}\text { Rua muito estreita calçada, sem árvores, densamente habitada, } \\
\text { posição sudeste }\end{array}$ \\
\hline 6 & Alto terra (CAIC) & $\begin{array}{l}06^{\circ} 28^{\prime} 03^{\prime \prime}, \mathrm{S} \\
37^{\circ} 06^{\prime} 34^{\prime \prime} \mathrm{O}\end{array}$ & 180 & $\begin{array}{l}\text { Ponto elevado, topo de encosta sobre solo natural, posição } \\
\text { norte }\end{array}$ \\
\hline 7 & Rua arborizada (Centro) & $\begin{array}{l}06^{\circ} 27^{\prime} 24^{\prime \prime}, \mathrm{S} \\
37^{\circ} 05^{\prime} 38^{\prime \prime} \mathrm{O}\end{array}$ & 160 & $\begin{array}{l}\text { Rua estreita calçada, completamente arborizada, posição } \\
\text { poente }\end{array}$ \\
\hline 8 & Rua de barro (Recreio) & $\begin{array}{l}06^{\circ} 26^{\prime} 43^{\prime \prime} \mathrm{S} \\
37^{\circ} 06^{\prime} 01^{\prime \prime} \mathrm{O}\end{array}$ & 160 & Rua larga de barro, sem árvore, posição nascente \\
\hline 9 & Periferia (Samanaú) & $\begin{array}{l}06^{\circ} 26^{\prime} 39^{\prime \prime} \mathrm{S} \\
37^{\circ} 04^{\prime} 54^{\prime \prime} \mathrm{O}\end{array}$ & 174 & $\begin{array}{l}\text { Periferia, rua levemente estreita e calçada, sem árvore, posição } \\
\text { nascente, próximo a área verde }\end{array}$ \\
\hline 10 & $\begin{array}{l}\text { Avenida principal (Coronel } \\
\text { Martiniano) }\end{array}$ & $\begin{array}{l}06^{\circ} 27^{\prime} 39^{\prime \prime} \mathrm{S} \\
37^{\circ} 05^{\prime} 44^{\prime \prime} \mathrm{O}\end{array}$ & 161 & Rua asfaltada, parcialmente sombreada, posição norte \\
\hline 11 & Área rural (pousada Céu Azul) & $\begin{array}{l}06^{\circ} 25^{\prime} 43^{\prime \prime} \mathrm{S} \\
37^{\circ} 04^{\prime} 58^{\prime \prime} \mathrm{O}\end{array}$ & 178 & Zona rural, aspecto natural, solo terra, posição norte \\
\hline
\end{tabular}

Fonte: dados da pesquisa 


\section{Parâmetros analisados e equipamentos utilizados}

Para analisar as características do clima urbano de Caicó neste trabalho focou-se no campo higrotérmico e por isso os parâmetros analisados foram a temperatura em ${ }^{\circ} \mathrm{C}$ e a umidade relativa do ar em \%. Foram utilizados onze termo-higrômetros automáticos da marca Akso AK170, que registraram dados horários de temperatura e umidade relativa do ar no período de trinta e dois dias. O período compreendido foi de 05/05/2016 a 05/06/2016. Esse período abrangeu o mês de maio quase todo e início de junho. A escolha não foi aleatória, mas devido a aquisição e instalação dos equipamentos termohigrômetros. De todo modo, deve-se destacar que neste ano de 2016, o período de coleta de dados foi de seca, pois houve registro de chuva fraca $<25 \mathrm{~mm}$ em apenas 3 dias.

Para instalação dos termo-higrômetros foram feitos abrigos meteorológicos que seguiram normas internacionais, que conforme Neves et al (2015), que são necessárias aos abrigos de forma a minimizar as interferências externas como a incidência direta da chuva, radiação solar e aerossóis, ao mesmo tempo que devem permitir a ventilação e a dissipação rápida de calor. Os abrigos foram feitos com canos de PVC e com um ralo de PVC branco a uma altura média de 1,70 metros dentro dos quais os termohigrometros foram colocados. A Figura 3 mostra o aspecto dos abrigos construídos e o equipamento utilizado.

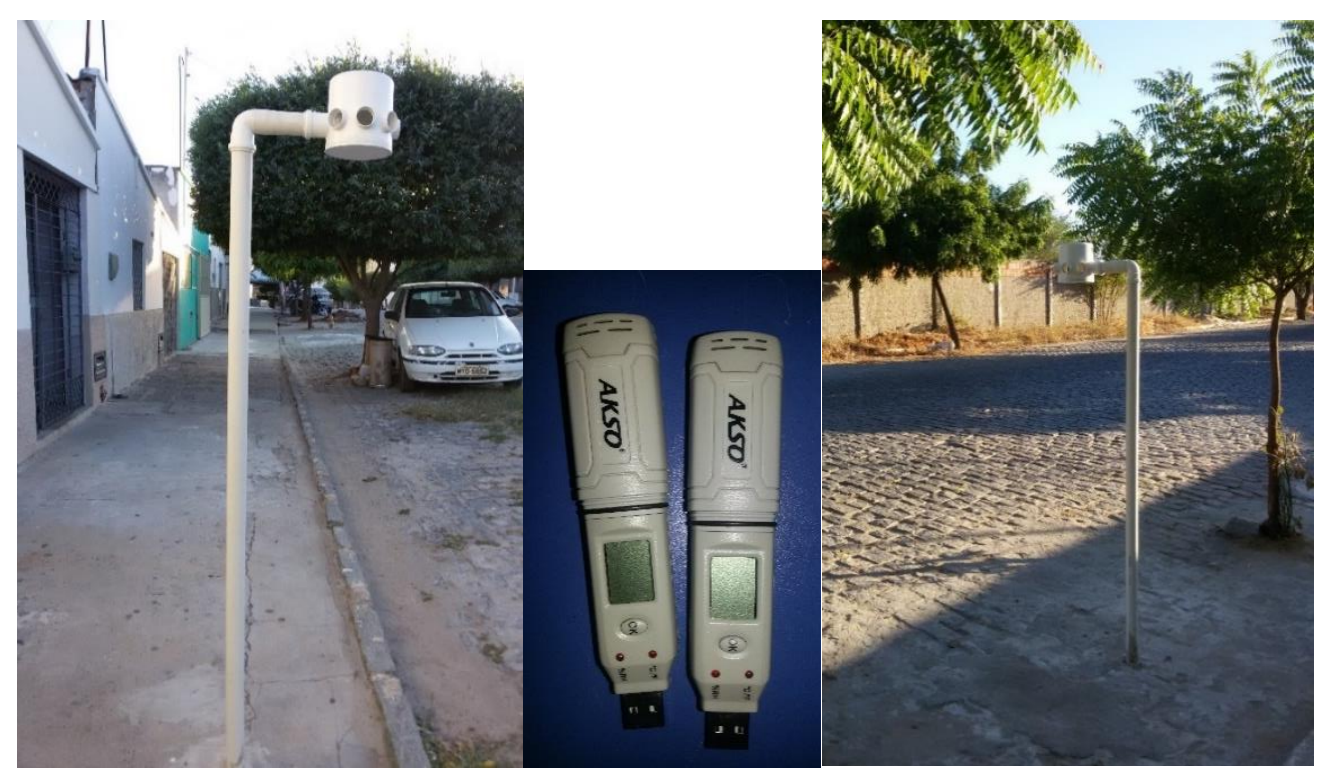

Figura 3 Termohigrômetros automáticos e os abrigos construídos. 


\section{Análise estatística e aplicação de índices de conforto térmico humano}

Para cada ponto de coleta, foram realizadas análises de estatística descritiva como Valor Máximo e Valor Mínimo; Amplitude Total, Média Aritmética e Coeficiente de Variação.

Posteriormente foram aplicados três índices de conforto térmico humano: O Índice de Desconforto (ID), O Índice de Temperatura Efetiva (TE), o Índice de Temperatura e Umidade (ITU). As fórmulas e as classes que qualificação estão expostas em DI (f1), TE (f2), ITU (f3), e nas Tabelas 2,3 e 4 .

Índice de Desconforto (ID) $=\mathrm{T}-0.55(1-0.01 \mathrm{UR})(\mathrm{T}-14.5)(\mathrm{f} .1)$

Onde: ID é o Índice de Desconforto em $\left({ }^{\circ} \mathrm{C}\right) ; \mathrm{T}$ é a temperatura do bulbo seco $\left({ }^{\circ} \mathrm{C}\right)$; e UR é a umidade relativa (\%). Dessa forma, têm-se os valores do Índice e Desconforto Térmico (ID), o qual é classificado em:

Tabela 2 Classificação (nível de conforto humano) segundo valores de Indice de Desconforto (ID).

\begin{tabular}{c|c} 
ID $\left({ }^{\mathbf{o}} \mathbf{C}\right)$ & Nível de desconforto térmico \\
\hline $\mathrm{ID}<21,0$ & Não há desconforto \\
\hline $21,0 \leq \mathrm{ID}<24,0$ & Menos de $50 \%$ da população sente desconforto \\
\hline $24,0 \leq \mathrm{ID}<27,0$ & Aprox. $50 \%$ da população sente desconforto \\
\hline $27,0 \leq \mathrm{ID}<29,0$ & A maioria da população sofre desconforto \\
\hline $29,0 \leq \mathrm{ID}<32,0$ & Todas as pessoas sentem estresse severo \\
\hline ID $\geq 32,0$ & Estado de emergência médica \\
Fonte: Matzarakis; Mayer, 1991.
\end{tabular}

$$
\text { Temperatura Efetiva }(\mathrm{TE})=\mathrm{T}-0.4(\mathrm{~T}-10)(1-\mathrm{UR} / 100)(\text { f. } 2)
$$

Onde: $\mathrm{T}$ é a temperatura do ar $\left({ }^{\circ} \mathrm{C}\right)$ e UR é a umidade relative do ar em (\%), classificado segundo a Tabela 3: 
Tabela 3 Sensação térmica sengundo os valores de Temperature Efetiva (TE).

\begin{tabular}{c|c} 
Temperatura Efetiva & Descrição da sensação humana \\
\hline $\mathrm{TE}>30$ & Muito quente \\
\hline $24 \leq \mathrm{TE}<30$ & Moderadamente quente \\
\hline $12 \leq \mathrm{TE}<24$ & Agradável \\
\hline $6 \leq \mathrm{TE}<12$ & Fresco
\end{tabular}

Fontee: Hentschel 1986 apud Suping et al, 1992.

Índice de Temperatura Umidade ITU $=0,8 * \mathrm{~T}+\mathrm{UR} * \mathrm{~T} / 500$ (f. 3)

Onde: T é a temperatura do ar $\left({ }^{\circ} \mathrm{C}\right)$; e UR é a umidade relativa (\%). A classificação respectiva consta na Tabela 4:

Tabela 4 Valores e sensação térmica relacionada ao Índice de Temperatura e Umidade (ITU).

\begin{tabular}{c|c} 
ITU & Sensação Térmica \\
\hline $21 \leq \mathrm{ITU} \leq 24$ & Confortável \\
\hline $24 \leq \mathrm{ITU} \leq 26$ & Levemente desconfortável \\
\hline ITU $>26$ & Extremamente desconfortável
\end{tabular}

Fonte: Nóbrega e Lemos, 2011.

Informações importantes sobre os índices de conforto humano aqui utilizados podem ser encontradas nos trabalhos de Matzarakis; Mayer (1991); Suping et al (1992), Nedel et al (2006), Santos (2011) e principalmente, no trabalho de Blazejczyk et al (2012), que traz a explicação e comparação entre vários índices de conforto térmico humano.

\section{Resultados}

No que diz respeito à temperatura média registrada no período de um mês em todos os pontos, observou-se uma diferença de $1,8^{\circ} \mathrm{C}$ entre a maior e menor média, sendo a maior registrada no ponto 10 (avenida principal), com $30,6^{\circ} \mathrm{C}$ e a menor média registrada no ponto 7 (rua arborizada) de $28,8^{\circ} \mathrm{C}$. As diferenças entre as temperaturas médias tendem a ser baixas, uma vez que a média aritmética 
suaviza as diferenças enquanto os valores de temperatura absolutos trazem diferenças mais expressivas como mostrados a seguir.

As maiores diferenças de temperatura notadas foram com relação às máximas absolutas, sendo a maior temperatura máxima de $42,7^{\circ} \mathrm{C}$ registrada no ponto 2 (Poente) e a menor temperatura máxima de $37,3^{\circ} \mathrm{C}$ registrada no ponto 11 (área rural), apresentando uma diferença de $5,4^{\circ} \mathrm{C}$ entre um local da zona urbana e outro com aspecto rural. Dentro da área urbanizada, esse diferença de temperatura entre os pontos caiu para $3,9^{\circ} \mathrm{C}$, do ponto 2 (Poente) $42,7^{\circ} \mathrm{C}$ para o ponto 9 (Periferia) que registrou a temperatura menor máxima absoluta em área urbana, de $38,8^{\circ} \mathrm{C}$.

Quanto às temperaturas mínimas absolutas, a diferença registrada foi menor que das temperaturas máximas, sendo de $2,5^{\circ} \mathrm{C}$ entre o ponto 10 (Av. principal) com $22,7^{\circ} \mathrm{C}$ e o ponto 11 (área rural) com $20,2^{\circ} \mathrm{C}$. Dentro do próprio ambiente urbanizado essa diferença foi de $2,3^{\circ} \mathrm{C}$ entre o ponto 10 (Av. principal), que registrou a maior temperatura mínima de $22,7^{\circ} \mathrm{C}$ e o ponto 6 (Alto terra) que registrou a menor temperatura mínima em área urbana de $20,4^{\circ} \mathrm{C}$.

Os dados nas Tabelas 5 e 6, apresentam o número de vezes em que se registrou determinada faixa de temperatura em cada ponto da cidade. 
Universidade de Brasília

GEA - Departamento de Geografia PPG/GEA- Programa de Pós-Graduação

Tabela 5 Número de registros de temperaturas superiores a $35^{\circ} \mathrm{C}$ e $40^{\circ} \mathrm{C}$, em cada ponto selecionado.

\begin{tabular}{|c|c|c|}
\hline Pontos & $\begin{array}{l}\text { n registros } \\
>=\mathbf{3 5}^{\circ} \mathrm{C}\end{array}$ & $\begin{array}{l}\text { n registros } \\
>=40^{\circ} \mathrm{C}\end{array}$ \\
\hline 1 - Nascente (Paraíba) & 142 & 0 \\
\hline 2 - Poente (Coacal) & 194 & 57 \\
\hline 3 - Vale (João XXIII) & 90 & 1 \\
\hline 4 - Alto pedra (Picanço) & 126 & 2 \\
\hline 5 - Rua estreita (Centro) & 135 & 0 \\
\hline $6-$ Alto terra (CAIC) & 140 & 1 \\
\hline 7 - Rua arborizada (Centro) & 24 & 0 \\
\hline 8 - Rua de barro (Recreio) & 116 & 0 \\
\hline 9 - Periferia (Samanaú) & 99 & 0 \\
\hline $\begin{array}{l}10-\text { Avenida principal (Coronel } \\
\text { Martiniano) }\end{array}$ & 187 & 21 \\
\hline 11 - Área rural (pousada Céu Azul) & 76 & 0 \\
\hline
\end{tabular}

Fonte: dados da pesquisa
Tabela 6 Número de registros de temperaturas inferiores a $24^{\circ} \mathrm{C} \mathrm{e} 22^{\circ} \mathrm{C}$, em cada ponto selecionado.

\begin{tabular}{l|c|c} 
Pontos & $\begin{array}{l}\mathbf{n} \text { registros } \\
<=\mathbf{2 4}^{\mathbf{}} \mathbf{C}\end{array}$ & $\begin{array}{l}\mathbf{n} \text { registros } \\
<=\mathbf{2 2}^{\mathbf{}} \mathbf{C}\end{array}$ \\
\hline 1- Nascente (Paraíba) & 81 & 4 \\
\hline 2- Poente (Coacal) & 82 & 5 \\
\hline 3 - Vale (João XXIII) & 71 & 2 \\
\hline 4- Alto pedra (Picanço) & 90 & 2 \\
\hline 5 - Rua estreita (Centro) & 43 & 0 \\
\hline 6- Alto terra (CAIC) & 95 & 8 \\
\hline - Rua arborizada (Centro) & 30 & 0 \\
\hline 8 - Rua de barro (Recreio) & 79 & 6 \\
\hline $9-$ Periferia (Samanaú) & 102 & 8 \\
\hline $10-$ Avenida principal (Coronel & 32 & 0 \\
Martiniano) & & \\
\hline $11-$ Área rural (pousada Céu Azul) & 78 & 2
\end{tabular}

Fonte: dados da pesquisa 
A partir da análise das médias e dos valores máximos e mínimos absolutos registrados, pôdese perceber que os pontos da 10 (Av. principal) e 2 (poente), foram aqueles que registraram as mais altas temperaturas médias, assim como as maiores temperaturas máximas, maior amplitude térmica e maior coeficiente de variação. O ponto 2 (Coacal), apresentou segunda maior média, maior temperatura máxima, maior número de registros de temperaturas superiores aos $35^{\circ} \mathrm{C}$ e maior número de superiores aos $40^{\circ} \mathrm{C}$. O ponto 10 (Av. principal) apresentou, além da maior média, segunda maior máxima absoluta, maior temperatura mínima absoluta, segundo maior número de registro de temperaturas superiores aos $35^{\circ} \mathrm{C}$ e $40^{\circ} \mathrm{C}$, e nenhum registro de temperaturas inferiores aos $22^{\circ} \mathrm{C}$. Esses dois pontos podem ser, portanto, considerados os mais quentes da cidade de Caicó, tomando-se por base a distribuição dos 11 termohigrômetros em estilo malha urbana.

O ponto 10 (Av. principal) apresenta altitude relativamente baixa, de $161 \mathrm{~m}$, típico aspecto urbano com rua asfaltada, muitos prédios, grande movimento de carros, apesar do ponto ser parcialmente sombreado pelas edificações na parte da tarde (ver Figura 4).

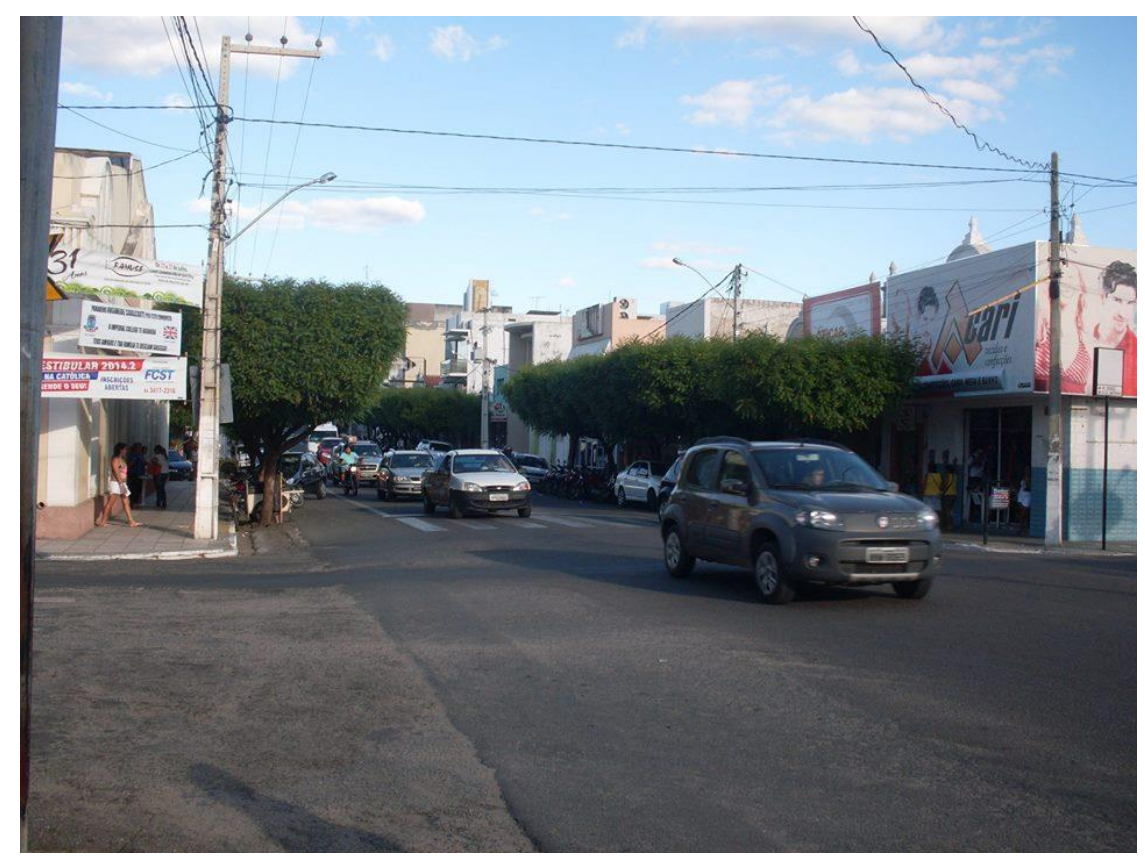

Figura 4 vista parcial da Avenida Coronel Martiniano (ponto 10).

Fonte: arquivo dos autores. 
O ponto 2 (Coacal/Poente) apresenta uma rua larga de calçamento, sem árvores, onde o termohigrômetro foi instalado na posição poente numa rua larga, estando exposto à insolação durante todo o dia (ver Figura 5).

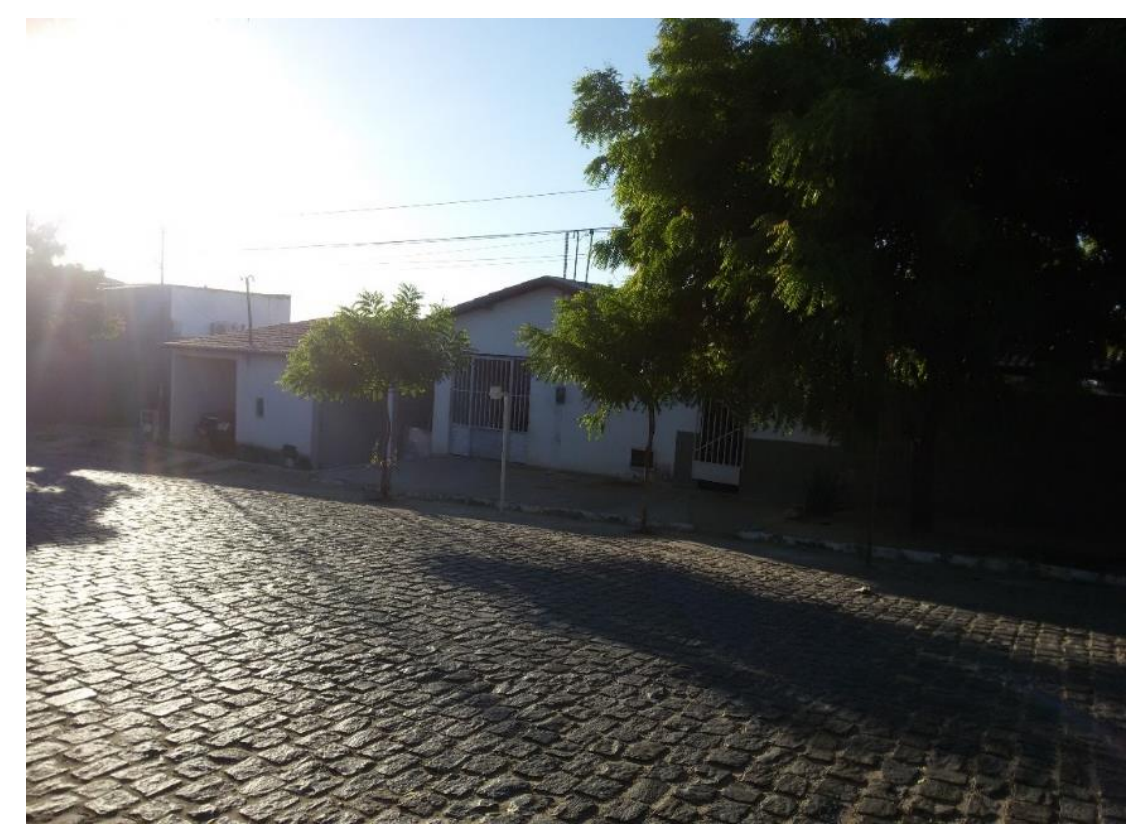

Figura 5 Vista do ponto 2 (Poente/Coacal).

Fonte: arquivo dos autores.

Já o ponto 11, Pousada céu azul (área rural), foi aquele que registrou os menores valores de temperatura máxima e a mínima absolutas, a segunda menor temperatura média, menores amplitudes e coeficiente de variação (Figura 6). 


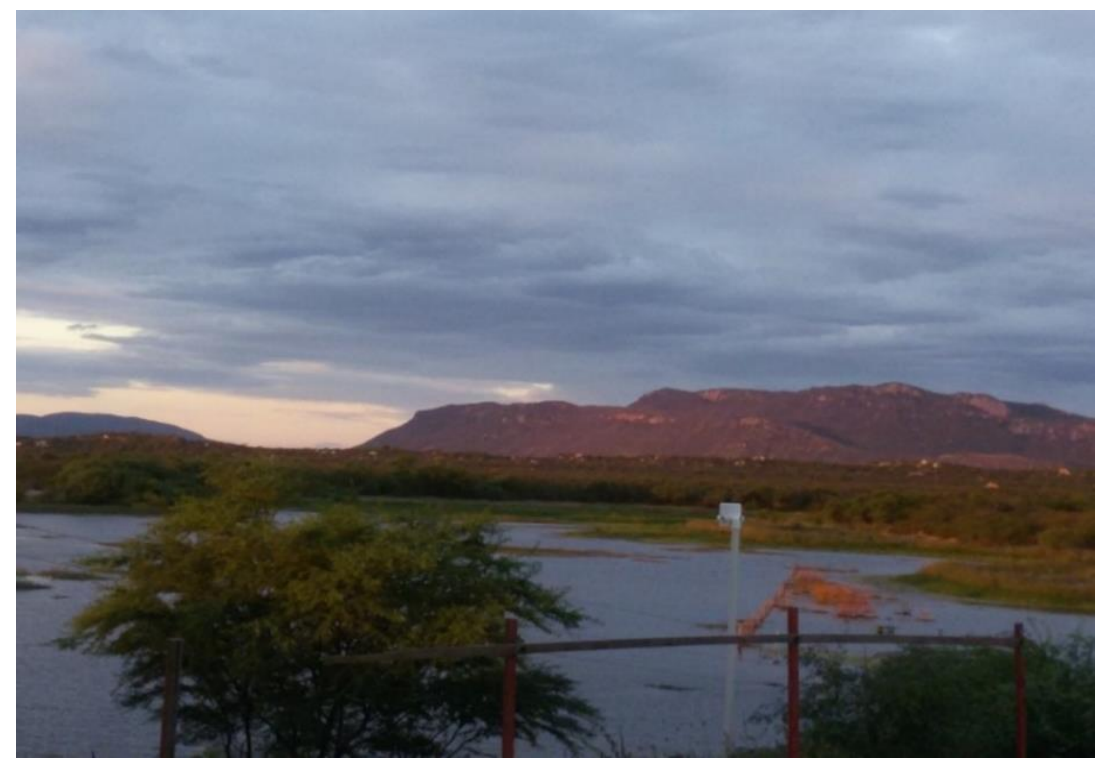

Figura 6 Vista da área rural (ponto 11) pousada Céu Azul. Fonte: arquivo dos autores.

O ponto 7 (rua arborizada), foi o que registrou menor temperatura média dentre todos os pontos analisados. Foi nele também que se registraram pouquíssimos valores de temperatura superiores aos $35^{\circ} \mathrm{C}$, apenas 24 vezes. Menor amplitude e coeficiente de variação também foi registrado neste ponto (ver Figura 7). 


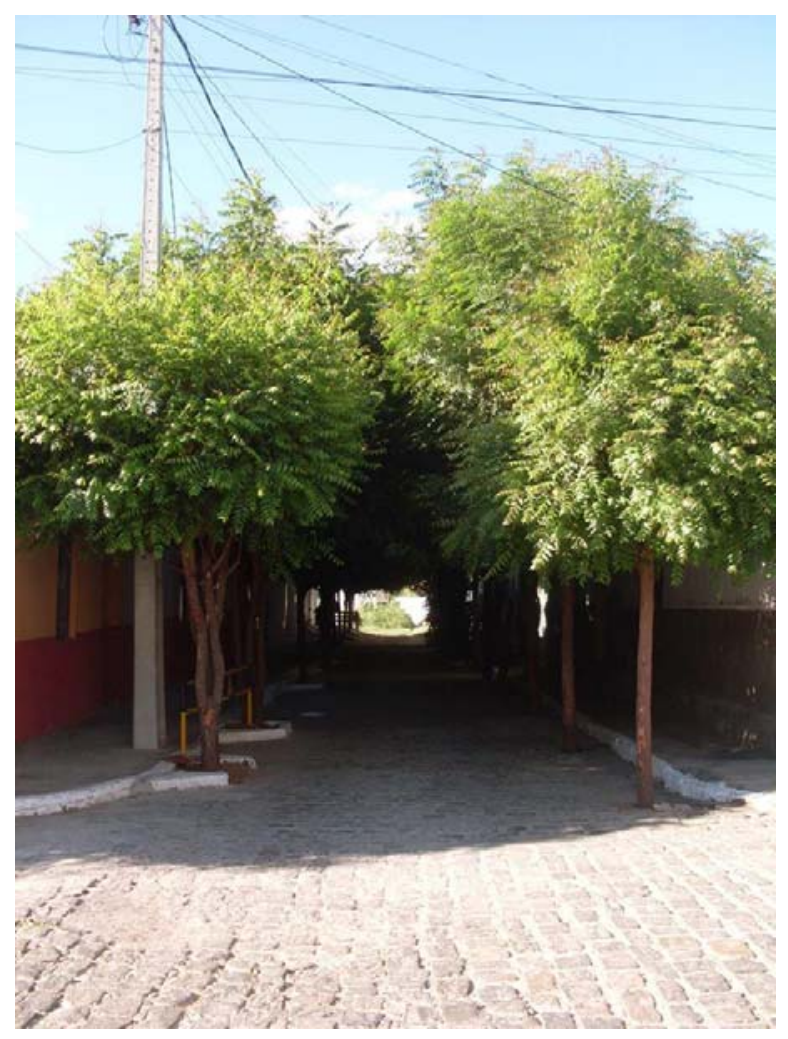

Figura 7 Vista da rua arborizada no centro (ponto 7).

Fonte: arquivo dos autores.

Os pontos 9 (periferia) e 3 (vale), também registraram médias mais baixas se comparadas aos demais pontos na área urbana, menos que 100 registros com temperaturas superiores aos $35^{\circ} \mathrm{C}$, com destaque para o ponto 9 (periferia) que também registrou uma das menores temperaturas máximas e mínimas, mais que 100 momentos de temperatura inferior aos $24^{\circ} \mathrm{C}$ e o maior número de temperaturas inferiores aos $22^{\circ} \mathrm{C}$ (ver Tabelas 5 e 6 ).

Quanto a análise da sensação térmica, foram realizadas médias diárias assim como a análise para a hora mais quente e mais fresca do dia para todos os pontos em questão. Segundo o Índice de Desconforto (ID) aplicado, todos os dias (média diária) no período da coleta estiveram "fora da zona de conforto humano" para todos os pontos em Caicó. Entretanto, dois pontos da cidade, o ponto 2 (Poente) e o ponto 10 (Av. principal), apresentaram pior condição quanto à sensação térmica, alcançando valores superiores a 27 onde, segundo este índice, significa que "maior parte da população sente desconforto devido ao calor", sendo que 4 dias do mês tiveram esse registro no ponto 10 (av. principal) e 3 dias do mês no ponto 2 (Poente), como pode ser visto na Figura 8. 


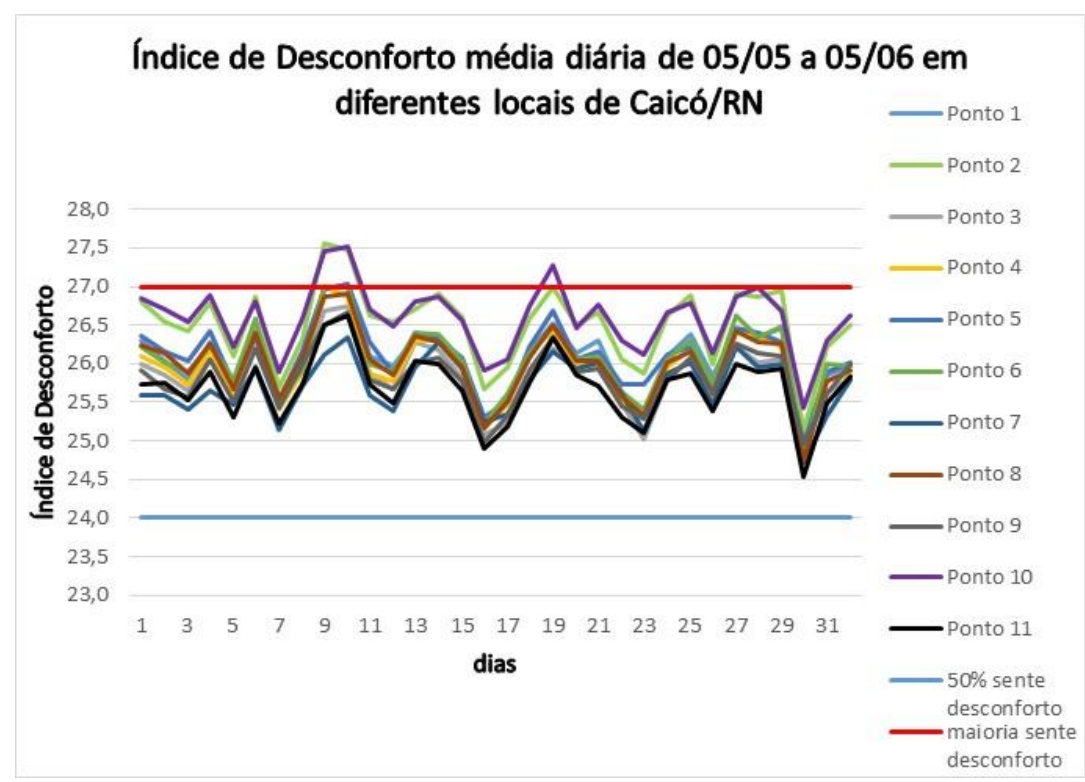

Figura 8 Valores médios diários de ID para diferentes locais no município de Caicó. Destaque para os pontos 2 e 10, que ultrapassam a faixa de "maior desconforto" em alguns dias do mês.

Fonte: dados da pesquisa.

De acordo com o índice de Temperatura Efetiva (TE), as médias diárias colocaram todos os pontos analisados na situação de "calor moderado", não havendo distinção detectável entre os diferentes pontos da cidade quando da aplicação deste índice (ver Figura 9). 


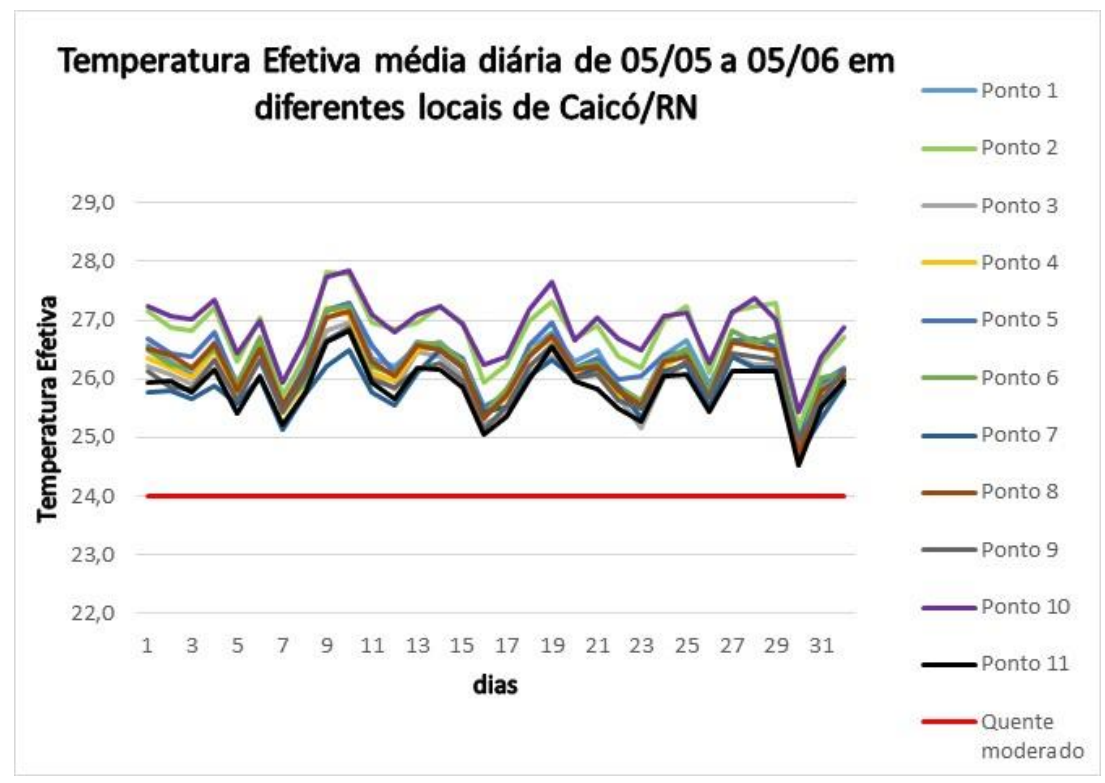

Figura 9 Valores médios diários de TE para diferentes locais no município de Caicó. Pode-se perceber no gráfico que todos os pontos ultrapassam a linha vermelha indicando "calor moderado".

Fonte: dados da pesquisa.

Segundo o Índice de Temperatura Umidade (ITU), exceto nos dias 07/05 e 30/05, todos os pontos apresentaram-se "extremamente desconfortável” devido ao calor. No dia 30/05 todos os pontos apresentaram "leve desconforto devido ao calor". O ponto 11 (área rural) apresentou 5 vezes "leve desconforto devido ao calor" sendo considerado o local menos desconfortável de Caicó para o período analisado, quando da aplicação do ITU. Este ponto é representado pela linha de cor preta na Figura 10. 


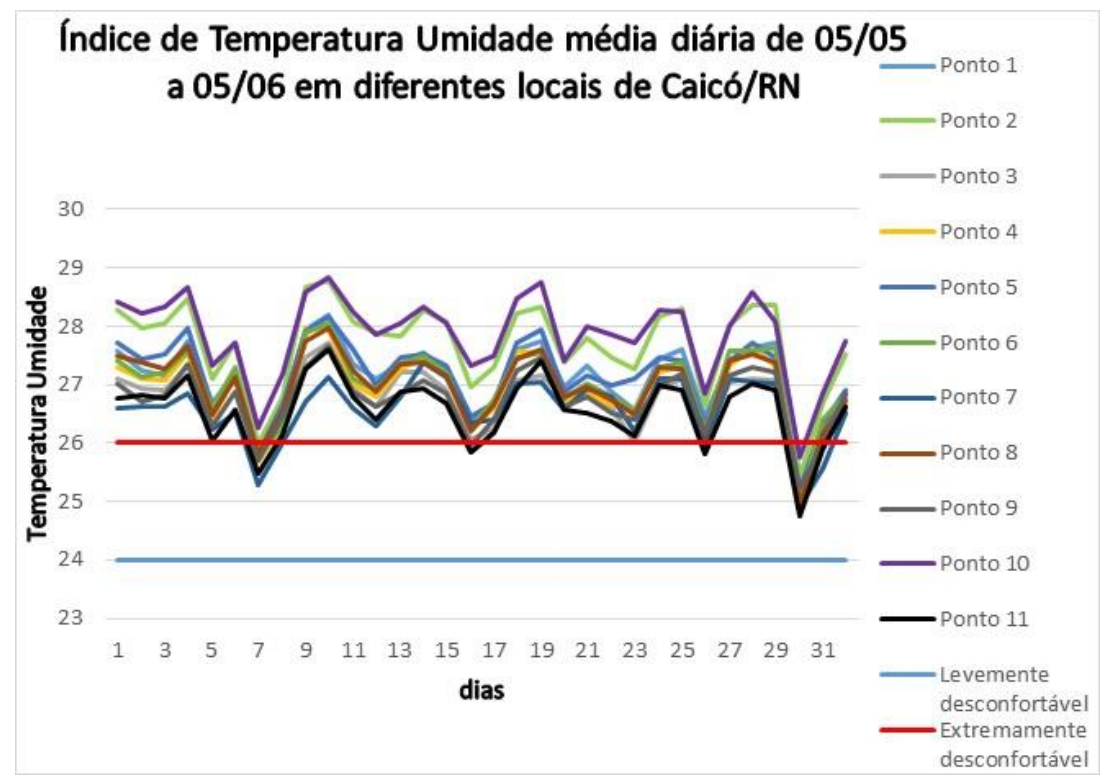

Figura 10 Valores médios diários de ITU para diferentes locais no município de Caicó. Mais uma vez, merecem destaque os pontos 2 e 10, que se apresentam sempre mais elevados (linhas verde e roxa) e o ponto 11 (linha preta) que está sempre na posição mais baixa.

Como os valores diários médios acabam por camuflar as variações horárias de temperatura, realizou-se a aplicação dos três índices de conforto térmico para a hora mais fresca do dia e a hora mais quente do dia. Conforme explica Varejão-Silva (2006) o valor máximo diário da temperatura do ar ocorre normalmente cerca de duas horas depois do ponto mais elevado do Sol, já a temperatura mínima diária ocorre de madrugada, minutos antes do nascer do Sol. Os horários foram eleitos por meio da observação das temperaturas máximas que se deram predominantemente as 14:30 h e mínimas registradas que foram por volta das 04:30 h. Desse modo, os resultados mostram uma grande diferença da média diária uma vez que todos os pontos irão apresentar uma mudança significativa quanto a sensação térmica detectada no decorrer do dia.

Para o Índice de Desconforto (ID) os pontos 2 (Poente) e 10 (Av. principal) apresentaram por volta das 14:30 valores de ID superiores a 29, situação onde "todas as pessoas sentem desconforto devido ao calor". Os demais pontos apresentaram para esta mesma hora valores superiores a 27 , onde “a maioria da população sente desconforto" devido ao calor. Destaque para os pontos 1 (Nascente/Paraíba) e 5 (Rua estreita/Centro) que atingiram o valor de 29 mas não o ultrapassaram. Porém, por volta das 04:30 da manhã todos os 11 pontos de Caicó registraram valores de ID inferiores a 24 , significando que " $50 \%$ da população sente desconforto", ver na Figura 11. Desse modo, diferente 
dos valores médios diários apresentados anteriormente que mostravam que "a maioria da população sente desconforto" devido ao calor, quando observada a variação entre dia e noite, a sensação térmica diária varia de " $50 \%$ da população sente desconforto" para "a maioria da população sente desconforto, até "todos sentem desconforto", para dois pontos específicos (2-poente e 10-Av. principal).

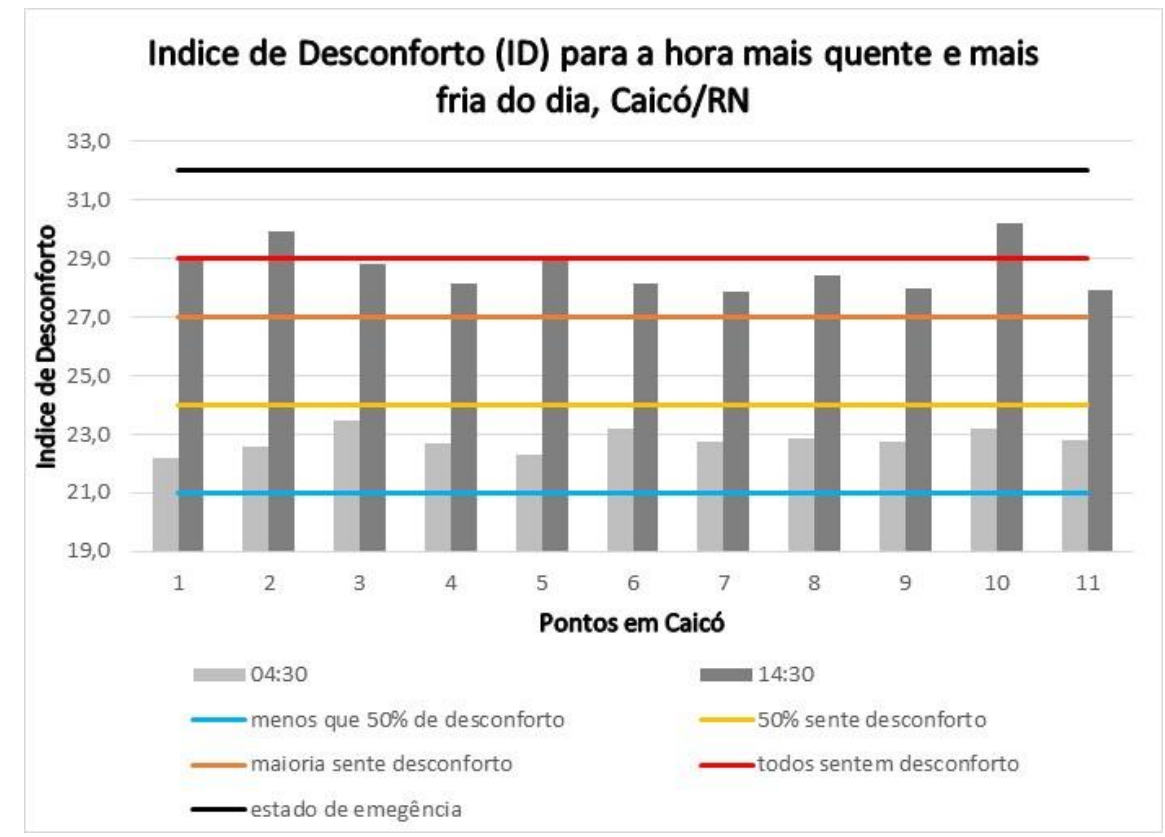

Figura 11 Índice de Desconforto aplicado para a hora mais quente e mais fresca do dia.

Fonte: dados da pesquisa.

Aplicando o índice de Temperatura Efetiva (TE), percebe-se que todos os 11 pontos apresentaram sensação térmica "agradável” por volta das 04:30 h da manhã (Figura 12). Nove pontos de Caicó registraram "calor moderado" próximo ao horário das 14:30 h. Mais uma vez, os pontos 2 (Poente) e 10 (Av. principal) apresentaram valores de TE superiores a 30, classificando esses dois lugares como "muito quentes" durante este período da tarde. Vale destacar que os pontos 1 (Nascente/Paraíba) e 5 (rua estreita/centro) atingiram o valor de TE de 30 mas como não foi superior a este, ainda foram classificados como "quente moderado", ver Figura 12. 


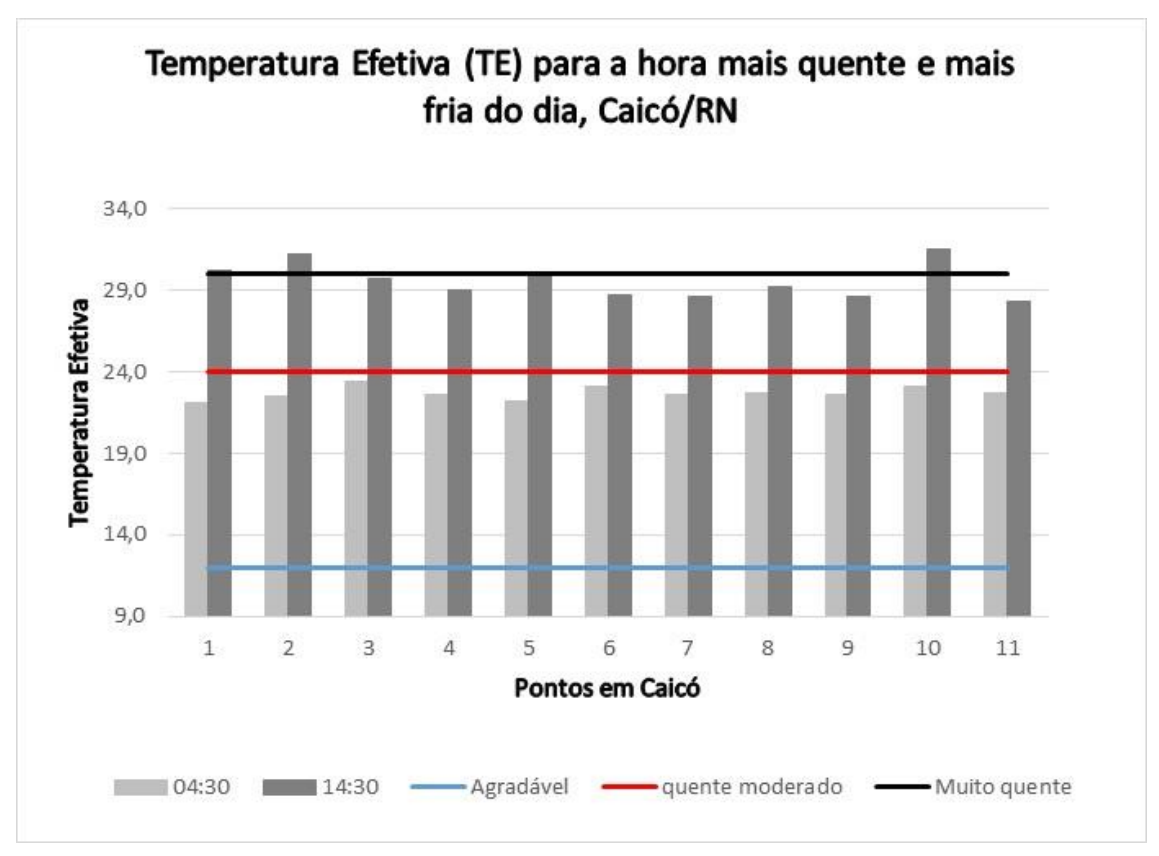

Figura 12 Índice de Temperatura Efetiva aplicado para a hora mais quente e mais fresca do dia.

Fonte: dados da pesquisa

Para o Índice de Temperatura e Umidade ITU todos os pontos em questão apresentaram-se com sensação térmica "confortável" para as 04:30 h da manhã indo para "extremamente desconfortável", devido ao calor, por volta das 14:30 h. Portanto, segundo este índice, todos os pontos apresentaram o mesmo comportamento, ou seja, uma elevada variação na sensação térmica entre dia e noite indo desde "confortável” até "extremamente desconfortável”, como pode ser visto na Figura 13. 


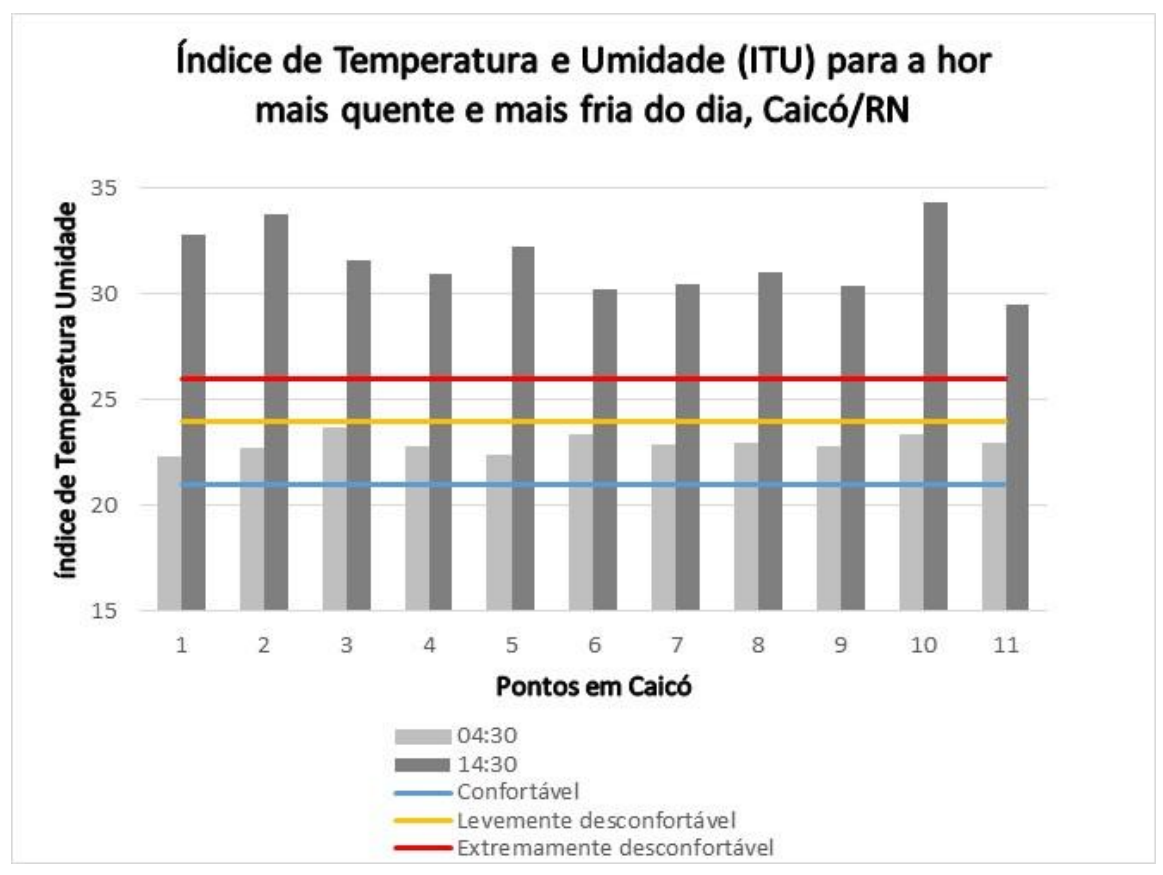

Figura 13 Índice de Temperatura e Umidade aplicado para a hora mais quente e mais fresca do dia. Fonte: dados da pesquisa.

\section{Considerações finais}

De acordo com os dados de temperatura e umidade relativa do ar coletados que possibilitaram a aplicação de índices de conforto térmico humano, constatou-se que o município de Caicó apresenta clima quente, mas que existem diferenças no município dentro da própria área urbanizada, assim como entre a área urbana e a rural.

Os pontos mais quentes e que obtiveram os resultados mais extremos com relação a sensação térmica e conforto humano foram os ponto 2 (poente/Coacal) e o ponto 10 (Avenida principal/Coronel Martiniano). As principais características que podem justificar os valores obtidos no ponto 2 são o fato de esta rua ser muito larga, com calçamento, com arbustos incapazes de produzir sombra e a orientação do termo-higrômetro voltado para o poente. Neste ponto recebe insolação desde o sol nascente até o poente devido a largura da rua e a falta de arborização. No ponto 10 (av. principal/Coronel Martiniano) características que podem justificar os altos valores de temperatura obtidos e o desconforto local podem estar relacionados ao fato de ser uma rua asfaltada, densamente construída (prédios), grande movimento de automóveis e pessoas, apesar de receber sombra durante a tarde, os materiais existentes, a exemplo do cimento e asfalto, se aquecem muito pela manhã e ao meio dia (Figura 14). 


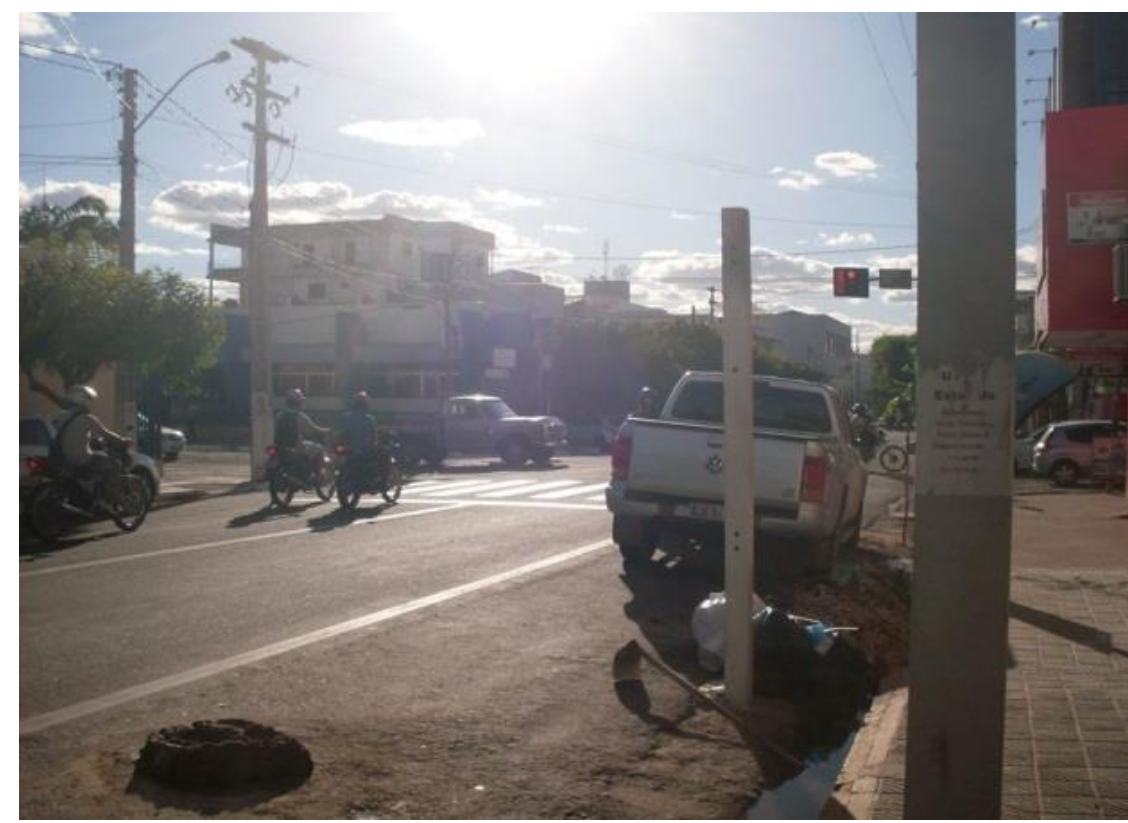

Figura 14 Imagem da avenida Coronel Martiniano (ponto 10), considerado o mais quente junto ao ponto 2 .

Já os pontos que registraram temperaturas mais amenas trazem consigo algumas características já conhecidas na literatura. O ponto 11 (área rural/pousada Céu Azul), por exemplo, possui áreas verdes, chão de terra, um açude próximo, é arejado, e só possui uma construção de alvenaria que é a sede da pousada.

O ponto 7 (rua arborizada/centro) que também obteve valores amenos de temperatura do ar e o mais baixo coeficiente de variação das temperaturas, agindo como uma mini-estufa e fazendo com que não se registrem temperaturas nem muito elevadas nem muito baixas, trata-se de uma rua completamente arborizada, estreita e onde há sombra o dia inteiro, ver figura 15. Esta rua, mesmo localizada no centro da cidade em área densamente construída, foi favorecida pela arborização urbana. 


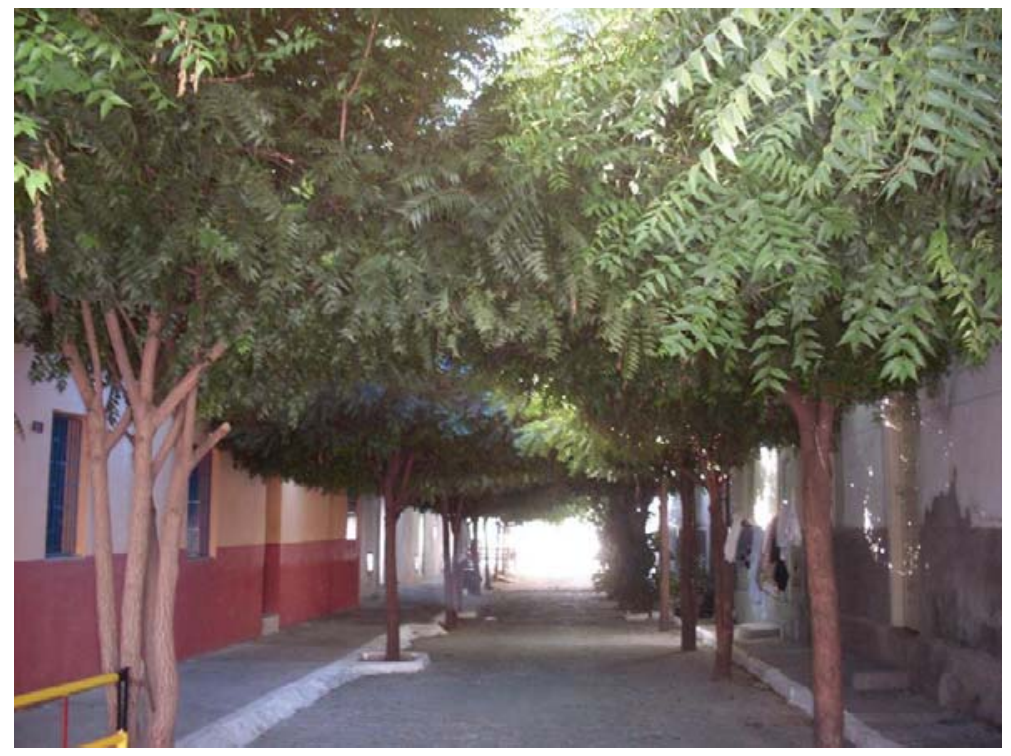

Figura 15 Aspecto sombreado da rua estreita e arborizada localizada no centro da cidade de Caicó (ponto 7).

O ponto 9 (periferia /Samanaú) que está mais afastado do centro, numa área periférica da cidade, próximo a áreas desabitadas e com vegetação, também registrou temperaturas mais amenas que os demais pontos da cidade.

Assim, comparando-se duas ruas largas, calçadas, em área urbana (pontos 1-nascente e 2poente), é possível concluir que a posição poente irá trazer muito mais desconforto quanto a sensação térmica do que a nascente, da mesma forma que comparando-se duas ruas calçadas e estreitas no centro da cidade (pontos 5-estreita e 7-estreita arborizada), é possível afirmar que o sombreamento oriundo da arborização é muito mais eficaz do que o sombreamento por edifícios, uma vez que o ponto 7 registrou muito mais temperaturas amenas que o ponto 5 . Os resultados mostraram uma grande diferença quando feita análise no decorrer do dia, e todos os pontos mostraram uma mudança expressiva quanto a sensação térmica detectada entre a hora mais quente e mais fria do dia.

Para o Índice de Desconforto (ID) os pontos 2 (Poente) e 10 (Av. principal) apresentaram por volta das 14:30 h valores de ID superiores a 29, situação onde "todas as pessoas sentem desconforto devido ao calor". Os demais pontos apresentaram para esta mesma hora valores superiores a 27, onde “a maioria da população sente desconforto" devido ao calor. Porém, por volta das 04:30 h da manhã todos os 11 pontos de Caicó registraram valores de ID inferiores a 24 , significando que "50\% da população sente desconforto". O índice de Temperatura Efetiva (TE), mostrou que todos os pontos 
apresentaram sensação térmica "agradável” por volta das 04:30 h da manhã (figura 12). Já as 14:30 h nove pontos de Caicó registraram "calor moderado" e os pontos 2 (Poente) e 10 (Av. principal) apresentaram-se como "muito quentes". Segundo o Índice de Temperatura e Umidade ITU todos os pontos mostraram condição "confortável" para as 04:30 h da manhã indo até "extremamente desconfortável", devido ao calor, por volta das 14:30 h.

Desse modo, é importante destacar que os resultados alcançados servem de subsídio ao crescimento urbano da cidade, uma vez que aponta práticas adequadas e inadequadas para a obtenção do conforto térmico humano. Ruas largas, asfaltadas e calçadas da forma e cor que são hoje, a precária arborização urbana e a exposição ao Sol poente são condições que tendem a colocar a população em condição de "extremo desconforto" devido ao calor. Ruas estreitas de orientação Norte-Sul, a exposição ao Sol nascente, a proximidade de áreas verdes, assim como a arborização urbana, produzem um microclima mais agradável que possibilitam uma melhor sensação térmica e, portanto, mais conforto e qualidade de vida para uma população que já vive numa região naturalmente muito quente, como é o caso da depressão sertaneja onde se encontra o município de Caicó.

\section{Referências Bibliográficas}

AB'SABER, A. N. 2003. “Caatingas: o domínio dos sertões secos”. In Os domínios de natureza no

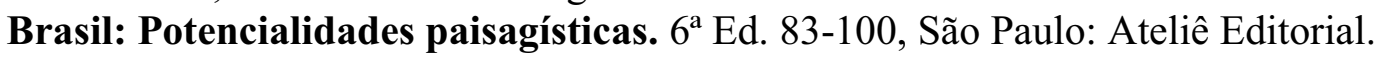

BLAZEJCZYK, Krzysztof; EPSTEIN, Yoram; JENDRITZKY, Gerd; STAIGER, Henning; TINZ, Birger. 2012. "Comparison of UTCI to selected thermal indices". International Journal of Biometeorology. 56:515-535. doi: 10.1007/s00484-011-0453-2.

FARIA, Carlos Eugênio de. Os eventos geográficos e a expansão urbana de Caicó. Natal: Editora do IFRN, 2011.

GARTLAND, L. Ilhas de calor: como mitigar zonas de calor em áreas urbanas. Tradução Silvia Helena Gonçalves. São Paulo: Oficina de Textos, 2010.

LANDSBERG, H. E. The climate of towns. In: THOMAS W. E. ec. Man's role in changing the face of Earth. The WennerGren Fundation Antropological Research. The University of Chicago Press, 1956.

LUCENA, J. A., SOUZA, B.I., MOURA, M. de O., LIMA, J. de O. Análise da variabilidade da precipitação pluviométrica como subsídio para o planejamento agrícola em Caicó/RN. Revista Brasileira de Climatologia. V.10 Jan/Jun, 2012, $121-135$ p. 
LUCENA, R. L; FERREIRA, A. M. FERREIRA, H. F. P. de A. STEINKE, E. T. Variabilidade climática no município de Caicó/RN: secas e chuvas num arquétipo do clima semiárido do Nordeste brasileiro. CLIMEP - Climatologia e Estudos da Paisagem. Rio Claro, Vol.8. p 25 -47, Jul/Dez, 2013.

; SANTOS, T. H. F. ; FERREIRA, A. M. ; STEINKE, E. T. . Heat and human comfort in a town in Brazil?s semi-arid region. The International Journal of Climate Change: Impacts and Responses, v. 8, p. 15-30, 2016. doi:10.18848/1835-7156/CGP

MATZARAKIS, Andreas and MAYER, Helmut. 1991. "The extreme heat wave in Athens in July 1987 from the point of view of human biometeorology". Atmospheric environment. 25b (2): 203 211. Accessed May 03, 2014. doi: 10.1016/0957-1272(91)90055-J

MONTEIRO, C. A. de F. Teoria e clima urbano. São Paulo: IGEO/USP, 1976. ; MENDONÇA, Francisco. 2003. Clima Urbano. São Paulo: Contexto, 2003.

NEDEL, A. S.; COELHO, M. de S.; GONÇALVES, F. L. T. 2006. Comparative analysis of different human thermal comfort indexes in São Paulo city and their relationship with respiratory morbidity. Proceedings of 8 ICSHMO, Foz do Iguaçú, Brazil, April 24 -28, INPE, p.675-677.

NÓBREGA, R. S., LEMOS, T. V. da S. O microclima e o (des)conforto térmico em ambientes abertos na cidade do Recife. Revista de Geografia (UFPE), v.8 Nº 1, 2011, 93 - 109 p.

ROMERO, Marta Adriana Bustos. Princípios bioclimáticos para o desenho urbano. Brasília: Editora Universidade de Brasília, 2013.

SANTOS, J. S. dos. 2011. Campo térmico urbano e a sua relação com o uso e cobertura do solo em cidade de clima tropical úmido. Tese de Doutorado, Programa de Pós-graduação em Recursos Naturais, Universidade Federal de Campina Grande (UFCG), 110p.

SUPING, Zhang., GUANGLIN, Meng., YANWEN, Wang, and JI, Li. 1992. "Study of the relationships between weather conditions and the marathon race, and os meteorotropic affects on distance runners." International Journal of Biometeorology. v.36: 63 - 68. January 25, 2014. doi: 10.1007/BF01208915.

TAHA, Haider. 1997. "Urban climates and heat islands: albedo, evapotranspiration, and anthropogenic heat." Energy and Buildings. 25: 99-103. Accessed November 01, 2013. doi: 10.1016/S0378-7788(96)00999-1

VAREJÃO-SILVA, M. A. Meteorologia e climatologia. $5^{\mathrm{a}}$ ed. Recife/PE: PAX Gráfica e Editora Ltda, 2006. 345p.

ZAVATTINI, J. A. Estudos do clima no Brasil. Campinas - SP: Editora Alínea, 2004. 398p. 


\section{CAPÍTULO 4 Registro de Software}

Este capítulo dedica-se a apresentar um o software "Conforto Humano" como uma ferramenta amigável que tem por objetivo fornecer informações sobre sensação térmica e conforto humano de um determinado lugar através de variáveis meteorológicas.

O programa pode oferecer informações sobreo conforto térmico esperado em um determinado local assim como fazer previsões, tudo depende dos dados climáticos que são inseridos na página pelo usuário (ver Figura 1).

O Conforto Humano é algo inédito, visto que este software é bilíngue (português e inglês) e de fácil acesso e manuseio, feito baseado em índices de conforto térmico humanos cientificamente reconhecidos. No Brasil, não existe nenhuma ferramenta com esta função, pois mesmo a ferramenta disponível no site do Instituto Brasileiro de Meteorologia - INMET, só possui uma escala para avaliação do conforto térmico humano para temperaturas até $20^{\circ} \mathrm{C}$, o que não condiz com a realidade de grande parte do território brasileiro. Outros sites como o do Meteorological Institute University of Freiburg, Alemanha, possui uma ferramenta semelhante, porém esta não é bilíngue e tem uma interface mais complexa uma vez que trabalha com um numero muito grande de variáveis, muitas vezes difíceis de se conseguir para muitos lugares desprovidos de estações meteorológicas completas.

Este software está em processo de elaboração, mas os domínios já foram comprados, a priori, pelos próximos 5 anos: Domínios comprados:

confortoclimático.com.br

confortohumano.com.br

\section{climatehumancomfort.com.br}

Inventores: Rebecca Luna Lucena - UnB/UFRN

Ercília Torres Steinke - UnB

Anderson Frota Portela - UECE

Joan Pontes - UECE

Angelo Filipe do Amaral Acácio - UECE 


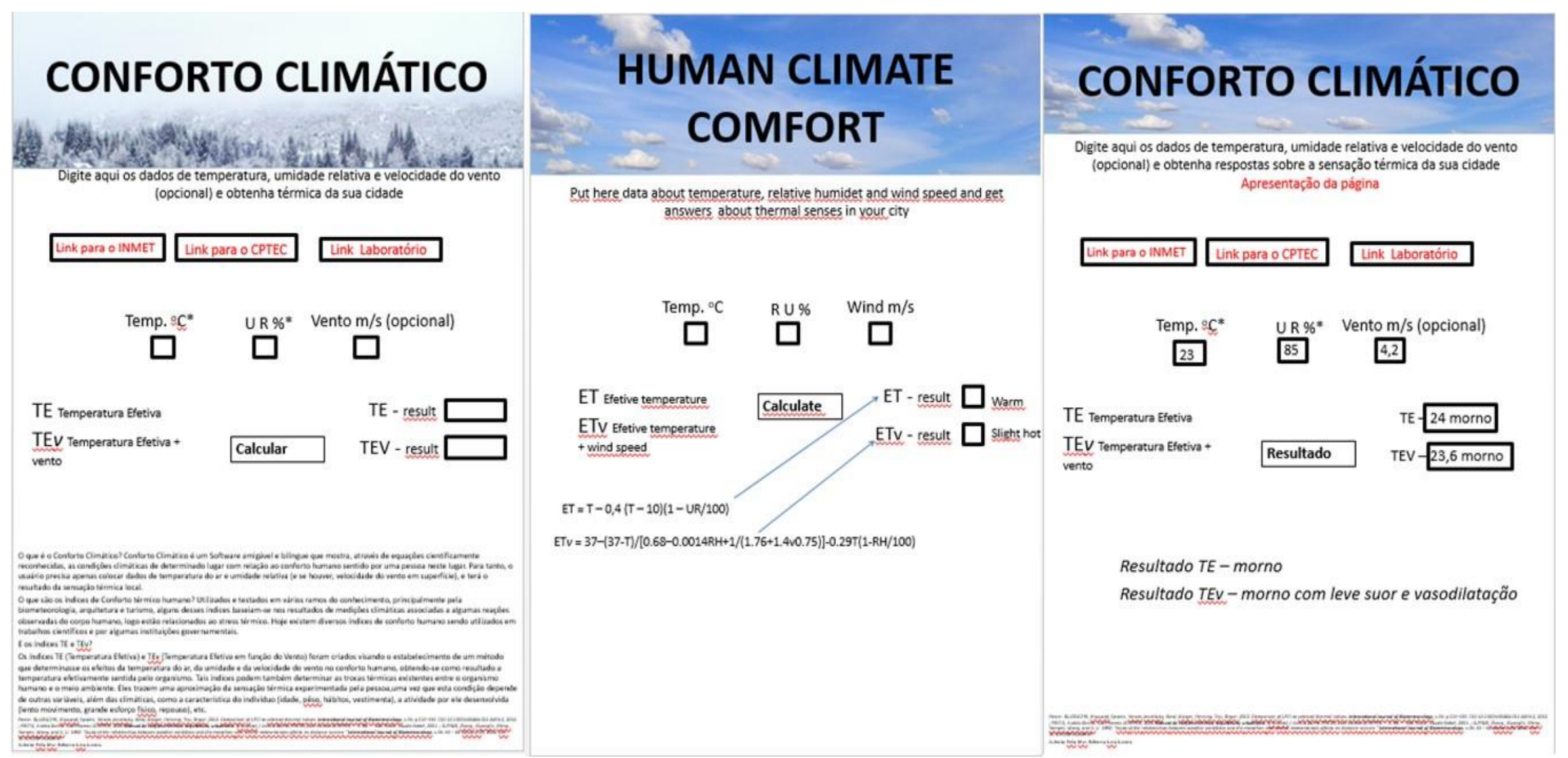

Figura 1 Interface do software em elaboração "Conforto Climático" "Human Climate Comfort". 


\section{CONSIDERAÇÕES FINAIS E PERSPECTIVAS}

De acordo com os resultados dessa pesquisa, foi possível identificar importantes características climáticas no estado do Rio Grande do Norte e no município de Caicó, nosso objeto de estudo. No que diz respeito aos campos hidroclimatológico e higrotérmico, os resultados encontrados servem como fonte de informação para promover a segurança hídrica e o conforto térmico em Caicó, e portanto, contribuir no sentido de diminuir a vulnerabilidade do município aos elementos do clima e para assegurar uma melhor qualidade de vida à população.

O campo Hidroclimatológico

O estado do Rio Grande do Norte pode ser considerado de clima subúmido e semiárido, visto que segundo as normais climatológicas, $75 \%$ dos municípios apresentam precipitações médias anuais inferiores aos $871 \mathrm{~mm}$.

$>$ Com distribuição espacialmente irregular das precipitações, pode-se facilmente identificar três domínios climáticos principais: um úmido no Litoral Leste que inclui a mesorregião do Leste potiguar e alguns municípios da mesorregião do Agreste potiguar; um sub-úmido seco que abrange quase a totalidade da mesorregião Oeste potiguar (sertão), além de alguns municípios da região Central e Agreste; e o domínio de clima semiárido, este presente em quase toda a mesorregião Central potiguar, incluindo alguns poucos municípios do Oeste e Agreste potiguar.

> O município de Caicó apresentou uma precipitação média anual de 659,9 mm se encontrando numa faixa de transição entre os tipos climáticos semiárido e sub-umido seco.

$>$ Os resultados também mostraram que a variabilidade interanual das chuvas é uma característica inerente ao clima de Caicó assim como de grande parte do domínio semiárido/subúmido do Nordeste brasileiro, como discutido em outros trabalhos.

Quando aplicado o Índice de Aridez (Ía), baseado em dados de precipitação e evapotranspiração, Caicó foi classificado como "semiárido" com "alta susceptibilidade ao processo de desertificação". 
Quando da aplicação do Índice de Aridez de Gaussen, este mostrou que em um ano "normal” assim como em um ano "chuvoso", há o predomínio de 7 meses secos, podendo chegar até 11 meses secos em um ano considerado "seco".

Nos 100 anos de dados de precipitação anual coletados, através da análise de regressão, descobriu-se não haver qualquer tendência para aumento ou diminuição das chuvas em Caicó. O tempo de retorno para cada faixa de precipitação no período de 100 anos consta na tabela 1 , onde se percebe que a faixa que vai de 471 a 835 milímetros tem um menor tempo de recorrência menor, ou seja, são os valores que têm maior probabilidade de ocorrência em curto prazo.

Tabela 1 Tempo de retorno para total anual de precipitação para Caicó, baseado no período de 1911 a 2010.

\begin{tabular}{c|c} 
Intervalo de Classe (precipitação anual) & Tempo de retorno (anos) \\
\hline $107-289$ & 9,9 \\
\hline $289-471$ & 7 \\
\hline $471-653$ & 3,5 \\
\hline $653-835$ & 4,7 \\
\hline $835-1017$ & 7,6 \\
\hline $1017-1199$ & 9,9 \\
\hline $1199-1381$ & 99 \\
\hline $1381-1563$ & 49,5
\end{tabular}

Fonte: dados da pesquisa

A elevada evaporação, reflexo da alta insolação, das altas temperaturas e da baixa umidade, coloca o município de Caicó em situação de vulnerabilidade hídrica (no âmbito climático), visto que as águas das chuvas que se concentram em um curto período do ano (janeiro a maio) ficam sujeitas o resto dos meses à forte evaporação, dimunuindo consideravelmente sua quantidade em superficie.

> A evaporação média anual é normalmente cinco vezes maior que a precipitação média anual.

$>$ No período de 100 anos de dados de chuva, pôde-se perceber que alguns anos de precipitação muito baixa coincidiram com fortes eventos de El Nino da mesma forma que anos com precipitações elevadas coincidiram com fortes eventos de La Nina. No entanto, este padrão não pode ser considerado o único determinante, uma vez que ocorreram anos de fortes episódios de El Nino onde as precipitações foram muito superiores a média e anos de forte episódios de 
La Nina onde as precipitações foram bem abaixo da média. As Tabelas 2 e 3 sintetizam alguns anos coincidentes e outros discrepantes quando da relação aos eventos El Niño e La Niña.

Tabela 2 Anos de forte El Niño e total anual de precipitação em Caicó

\begin{tabular}{l|l} 
Episódio de El Niño / Ano & Total anual de precipitação \\
\hline 1915 & $154,5 \mathrm{~mm}$ \\
\hline 1925 & $1085,1 \mathrm{~mm}$ \\
\hline 1932 & $111,1 \mathrm{~mm}$ \\
\hline 1951 & $251,1 \mathrm{~mm}$ \\
\hline 1963 & $1148,4 \mathrm{~mm}$ \\
\hline 1972 & $979,7 \mathrm{~mm}$
\end{tabular}

Fonte: Grimm, (1998) e dados da pesquisa

Tabela 3 Anos de forte La niña e total anual de precipitação em Caicó

\begin{tabular}{l|l} 
Episódio de La Niña / Ano & Total anual de precipitação \\
\hline 1917 & $845,5 \mathrm{~mm}$ \\
\hline 1928 & $264,8 \mathrm{~mm}$ \\
\hline 1942 & $222,1 \mathrm{~mm}$ \\
\hline 1964 & $1351,5 \mathrm{~mm}$ \\
\hline 1970 & $455,1 \mathrm{~mm}$ \\
\hline 1985 & $1558,3 \mathrm{~mm}$
\end{tabular}

Fonte: Grimm, (1998) e dados da pesquisa

Portanto, diante de todos os dados aqui analisados e discutidos com outros trabalhos sobre o tema, concluiu-se que a instabilidade e a variabilidade das chuvas são próprias do clima de Caicó/RN. Os sistemas de circulação atmosférica associados aos fatores geográficos do clima geram a forte instabilidade interanual no total das precipitações. Além da grande variabilidade das precipitações, o agravante da semiaridez está intimamente vinculado às altas taxas de evaporação. Nesse contexto, as ações de planejamento e gestão dos recursos hídricos devem ser prioritárias para assegurar água para a população e para o desenvolvimento de suas atividades. Essas ações devem envolver o meio rural e o meio urbano. 
Deve haver uma forte campanha para que hajam ações em prol do armazenamento adequado das águas assim como da proteção dos corpos hídricos naturais ou artificiais através da preservação e conservação da vegetação ciliar e dos solos que a sustenta. Outra ação muito importante é a preservação da Caatinga nas áreas serranas, uma vez que muitas nascentes de rios do semiárido nordestino nascem nas áreas serranas ou no sopé delas. A preservação da Caatinga nas áreas prioritárias, sejam serras, nascentes e matas ciliares deve ser imprescindível. A conservação das Caatingas nas áreas consideradas não prioritárias (em termos de preservação permanente), deve ocorrer através do manejo adequado das mesmas.

A instalação de Renques e barramentos em áreas de Caatinga degradada visando a recuperação da floresta e dos solos - segurar os solos em áreas degradadas desertificadas ou em processo de desertificação - também deve ser instituída como uma política pública no semiárido.

$\mathrm{O}$ armazenamento adequado das águas durante o período chuvoso é também de capital relevância no sentido de garantir o abastecimento humano, animal dentre outros usos múltiplos da água. Nessa perspectiva, ações de dragagem de rios e açudes assoreados, o conserto e manutenção das grandes obras hídricas: paredes de açudes, pontes, passagens molhadas, assim como a adequada drenagem e limpeza urbana - são ações necessárias, que junto às alencadas anteriormente, podem garantir o abastecimento de água para a população e diminuir os impactos dos períodos de seca que afetam habitualmente o município de Caicó e o estado do RN.

Por último, a economia no uso da água - em todos os setores (rural, urbano, industrial), por meio de subsídios e/ou incentivo financeiro, parece ser uma boa saída para uma mudança de paradigma voltada ao consumo consciente em um mundo, região e município com população crescente.

\section{O campo higrotérmico}

- As análises de temperatura do ar mostraram que o município de Caicó/RN possui, naturalmente, temperaturas elevadas durante todo o ano, com média de $30^{\circ} \mathrm{C}$, média das máximas de $35^{\circ} \mathrm{C}$ e média das mínimas de $24^{\circ} \mathrm{C}$.

Diferentemente da variável precipitação, as temperaturas (máximas, médias e mínimas) pouco variam anualmente e interanualmente. 
Os índices de conforto humano quando aplicados para a média histórica (meia normal), classificaram Caicó como uma cidade "quente", portanto "fora" da zona de conforto humano devido ao calor (média anual).

Quando aplicados para cada mês do ano (média mensal), os índices de conforto térmico humano mostraram resultados distintos, uma vez que dois índices o Temperatura Efetiva em Função do Vento (TEv) e o Indice Térmico Climático Universal (UTCI), identificaram alguns meses do ano como "confortáveis".

O Índice de Desconforto (ID) mostrou que Caicó não possui nenhum mês (média mensal) dentro da "zona de conforto humano" mostrando que durante o ano inteiro a população está sujeita ao "desconforto devido ao calor". O índice UTCI, classificou os meses de junho, julho e agosto como "confortáveis". O índice TEv foi o único que detectou uma melhor condição de conforto, colocando os meses que vão de maio à outubro dentro da zona de conforto térmico humano, possivelmente por trazer consigo a variável velocidade do vento.

Apesar de Caicó está sob um domínio climático regional semiárido quente, percebeu-se que existem diferenças térmicas dentro do próprio município, seja em diferentes locais da área urbanizada, seja entre a área rural e a urbanizada.

Dos 11 pontos de coleta de dados termohigrométricos espalhados na malha municipal de Caicó, 6 apresentaram condições térmicas e de conforto humano semelhantes, 2 se destacaram por apresentarem-se mais quentes e "desconfortáveis" que os demais e 3 apresentaram-se como os "menos quentes".

Os 2 pontos mais quentes da cidades não estão próximos espacialmente.

O segundo ponto considerado mais quente (ponto 10 - Av. principal) e o segundo ponto considerado menos quente (ponto 7 - rua arborizada) estão muito próximos um do outro e ambos se localizam no centro da cidade de Caicó, numa área densamente habitada. (ver Figura $01)$. 
Universidade de Brasília

GEA - Departamento de Geografia PPG/GEA- Programa de Pós-Graduação

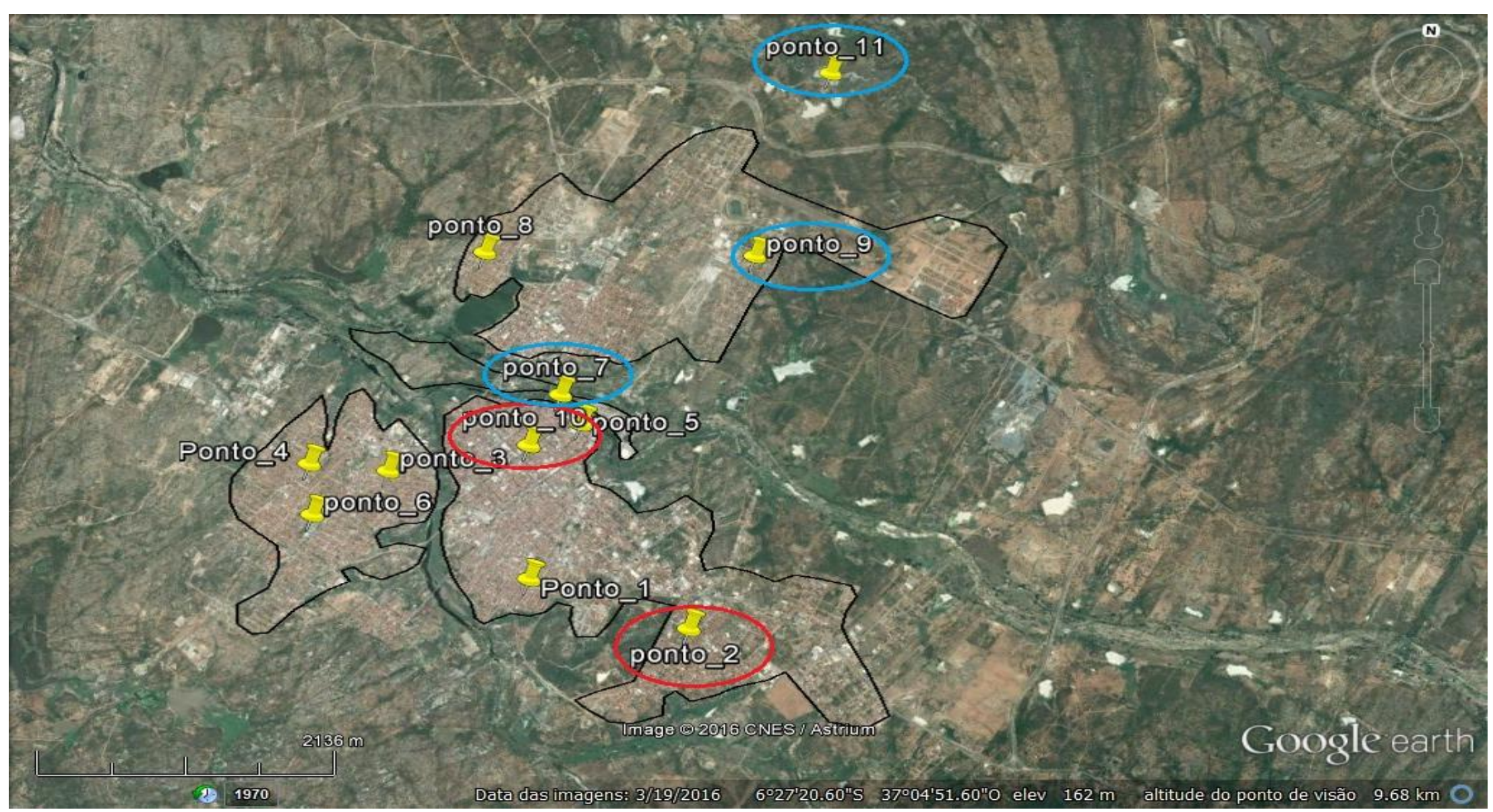

Figura 1 os pontos mais quentes (vermelho) e os pontos menos quentes (azul) em Caicó. Os demais pontos que não estão em destaque apresentaram condições termohigramétricas semelhantes entre si. Fonte: dados da pesquisa, imagem Google Earth. 
$>\mathrm{O}$ ponto 2 (Poente) considerado o mais quente possui como características principais uma rua muito larga, sem sombreamento, com calçamento e voltada à posição poente e o segundo segundo ponto mais quente, ponto 10 (Av. principal), apresenta como características principais uma avenida asfaltada, com sombreamento parcial exercido pelas edificação, orientação lesteoeste, fazendo com que o asfalto esteja exposto à insolação o dia todo e grande fluxo de veículos e pessoas.

$>$ Os três pontos considerados mais frescos foram: o ponto 11 (área rural), o ponto 7 (rua arborizada e o ponto 9 (periferia) (ver figura 1). O ponto 11(rural) possui como características principais aspecto rural, cercado com áreas verdes, com um açude próximo e chão de barro. $\mathrm{O}$ ponto 7 (rua arborizada) é uma rua localizada no centro da cidade porém sua principal característica é ser uma rua estreita e completamente arborizada, fazendo com que não haja insolação em nenhuma hora do dia, neste caso, a orientação poente em nada interferiu e o ponto 9 (periferia) tem como características principais posição nascente, rua calçada, porém muito próxima a uma área desabitada, como pode-se ver na figura 1.

$>$ Quando da aplicação dos índices de conforto térmico humano, Temperatura efetiva (TE) e Índice de Temperatura e Umidade (ITU), todos os 11 pontos espalhados em Caicó apresentaram "desconforto devido ao calor" para a média diária. Apenas o Indice de Desconforto ID obteve resultado diferente, pois classificou os pontos 2 (poente) e 10 (av. principal) como "extremamente quentes", enquanto os demais pontos foram classificados como "moderadamente quentes", em se tratando da média diária

$>$ Quando realizada a análise horária, os resultados mostraram uma grande diferença na sensação térmica no decorrer do dia, e todos os pontos mostraram uma mudança expressiva entre a hora mais quente $\sim 14: 30 \mathrm{~h}$ e mais fria $\sim 04: 30 \mathrm{~h}$ do dia.

$>$ Para o Índice de Desconforto (ID) os pontos 2 (Poente) e 10 (Av. principal) apresentaram por volta das 14:30 h valores superiores a 29 , situação onde "todas as pessoas sentem forte desconforto devido ao calor". Os demais pontos apresentaram nesta mesma hora valores superiores a 27, onde "a maioria da população sente desconforto devido ao calor". Porém, por volta das 04:30 da manhã todos os 11 pontos de Caicó registraram valores de ID inferiores a 24 , significando que " $50 \%$ da população sente desconforto devido ao calor", 
O índice de Temperatura Efetiva (TE), mostrou que os 11 pontos apresentaram sensação térmica "agradável" por volta das $04: 30$ h da manhã. Já as 14:30 h 9 pontos de Caicó registraram "calor moderado" e 2 pontos: o 2 (Poente) e o 10 (Av. principal) apresentaram-se como "muito quentes".

$>$ Segundo o Índice de Temperatura e Umidade ITU todos os pontos mostraram condição “confortável” para as $04: 30 \mathrm{~h}$ da manhã indo até "extremamente desconfortável devido ao calor", por volta das 14:30 h.

Através dos resultados obtidos, pôde-se perceber que a amplitude diária de temperatura e umidade no município de Caicó mostrou, através da aplicação dos índices de conforto térmico humano, uma situação de grande variação na sensação térmica durante a hora mais quente e mais fresca do dia. Anualmente esta diferença foi menor.

Mesmo estando sob um domínio climático regional quente e semiárido, as modificações na superfície realizadas pela ação humana geraram variações no campo termo-higrométrico ao nível local, no município de Caicó, ao ponto de expor, em determinado horário e lugar, a população à situação de “extremo desconforto devido ao calor". Esse estresse térmico pode gerar uma série de problemas tanto no âmbito da saúde quanto no bem estar e na qualidade de vida da população. Assim, quando ruas largas são comparadas com ruas mais estreitas, ruas intensamente arborizadas comparadas com ruas expostas à insolação ou sob sombreamento de edifícios, ruas com orientação norte-sul comparadas com ruas com orientação leste-oeste, ruas de chão de barro comparadas com ruas asfaltadas, e áreas densamente ocupadas e construídas comparadas com áreas verdes e abertas, pode-se afirmar que existe uma diferença térmica real fruto da ação humana mas que também pode ser controlada por ela. Assim, corrobora-se com Monteiro 2003, quando este afirma que o Sistema Clima Urbano "é passível de autoregulação, função esta conferida ao elemento homem urbano que, na medida em que conhece e é capaz de detectar suas disfunções, pode, através de seu poder de decisão, intervir e adaptar o funcionamento do mesmo, recorrendo a dispositivos de reciclagem... capazes de conduzir o seu desenvolvimento e crescimento seguindo metas preestabelecidas" p 25. O mesmo afirma que pela possibilidade de interferência auto-reguladora, pela sua própria capacidade de especialização dentro do crescimento através de processos adaptativos, o clima urbano pode ser qualificado como um sistema morfogenético. 
Assim, medidas que visem a minimização do calor devem ser prioritárias sob estas condições climáticas. Numa perspectiva de crescimento urbano, o plano diretor da cidade de Caicó deve incluir ações no sentido de buscar o conforto térmico. O favorecimento da ventilação, a diminuição do uso do vidro nas fachadas dos edifícios e uma ampla ação de arborização urbana devem estar na ordem do dia. Também a estrutura, material e orientação das construções deve ser levada em conta. Numa cidade cada vez mais cheia de automóveis, ruas estreitas se tornam difíceis para locomoção, neste sentido resta a arborização urbana intensa, de preferencia com espécies arbóreas de grande porte. 

PPG/GEA- Programa de Pós-Graduação

ANEXOS 
Anexo 1 artigo 1 do capítulo 3 publicado em inglês revista international journal of climate change: impacts and responses - na íntegra

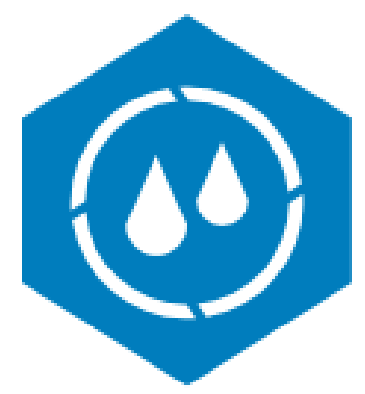

The International Journal of

\section{Climate Change: Impacts and Responses}

\section{Heat and Human Comfort in a Town in}

\section{Brazil's Semi-arid Region}

FEEECCA UNA WCENA TACIO HENFCUE DE FEETIS SANTOS, NMR MFWNA FEFEFA AND ERCLLA TOAFES STENKE 


\section{The International Journal of Climate Change: Impacts and Responses}

www.en-elimate.som

dei:10 1834 /3/1835-7456/COD (Journal)

Firat published in 2016 in Champrirn, Mllimein, USA by Commen Ground Vubliahin

www.ceemenengroundyublishing, cem

The International Sournal of Climate Chaspe: Impaet and Rerponser is a peer-revieved, sehelerly joureal.

Editor

Candies Hewarth, Anglia Reakin Uaiverity, UK

Community Editor

Amenda Sabe, Cemmen Geound Dublishinr

\section{Advisory Board}

Uiven Andervog, Uaiveraity of Dhmouth, UR

Tapon Cheirrobart, Natiesal Emvironmental Engiecering

Resentch Inatitute (NEERM), Indis

Gevtam Raj Chintarn=, AN7Rus/Earth-Shuritiu,

Mauritioa

Candies Hewarth, Anglis Ruskin Uninerxity, UT:

Themas Braff, Ceomed Reuerth Corperetien, Cermem

Merdechei Shechter, Uaviveraity of Haifa, Iaroel

Gerden Wilues, The Open Univeruity, UK.

Zhiken Zheng, Beijing Normal Univernity, China

\section{Associate Editors}

Artiela publixbed in The Internationel Journal of

Climate Change: Impoets and' Rcpongar ore pref

reviewed by aholara whe are retive pertieigenta of the

revewed by debolara whe are setive participonta of

Chimete Chang = impecta S: Reaponass Knowileds

Community of $\mathrm{s}$ thematically releted Knguledge

Community, as well a Commen Groued Doblahing

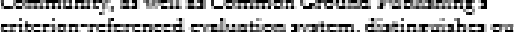

peer-reniew peocens. In recregnition of the valuable

provide, reviswera are acknerdedred a dasocinte Editer

in the voleme that ifeludea the article[(1) ther hove

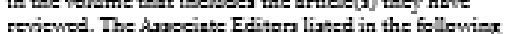

link heve enntributed airnifieantly to the overall editorial

tink heve eontributed and eontent of the journs

quelity and eontent of the jorral:

Article Submission

The International Vournal of Climate Cheope: Impact

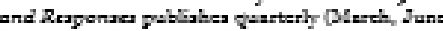

September, Deetmber]. Dlease viait

www.en-elimate.eom//jeurnal/enI-for-zrtiele to find eut more about the aubmisuien proses.

\section{Abstracting and Indexing}

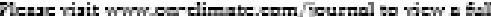
list of detrbasa is which this journal is indexed.

Knowledge Community Membership

Kethera in The Internationel Journal of Climate Alhers in The Internationel Journal of Chmate Chenpe: Impoeta and Reaponacs ere membera of the

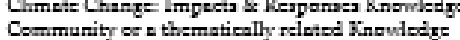
Community or a thematically releted Kneviedge Community. Membera reseive seesas to joarnal esnt

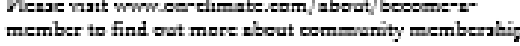

\section{Our Model}

We are werking to changs the way in which knewledre is valued. Vuther than foeduing volehy on accoptaner reter

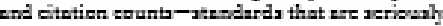
freaght-ue measure quality by a eriterien-beasd peer review prosesu, emesinx the intellectasl exerllener and secesuibility of the werk axrient elexthy artiealated disciplinary atandarda. Werve rijit

wvw.en-elimate.com//ournel/model to find out mere.

\section{Subscriptions}

The International Nournal of Climeate Change: Impact and Rexponses is eveilable in elestrenic end print fermeis. Sabouribe to gain acoeas to content from the current year and the entire boekliat. Coatest a

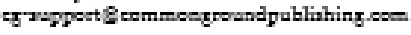

Ordering

Single articlea sod ixvea are arvilable frem the journal bookatere at www-ije egpubliaber.eom.

Hybrid Open Aceess

By pabliahing in The International Journal of Climete their articles rvailable to s lerge number of achelera whe heve individual whacriptions or whese iextitutions aubseribe. The International Journal of Climele Change: exthera exs alas checse to make ther artielea opes codience, bendenin the dimeminotion of their maere ond potentially iecrening the incidenos of other acholes citing their work Vlease viait

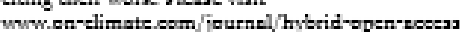

to find eut mere about eur Open Alesesu aption.

Disclaimer

The authorn, editorn, end pabliaher will set aecept z=y

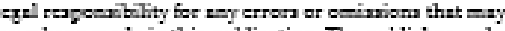
heve been made in this publiestion. The publiaher makes na warrenty, expreas or implied, with reapert to the material eantained herein.

\section{Copyright and Copying}

Q 2016 (individual papern), the euther(a)

2016 (velection and editorial matter) Commen

Ground Dublishing

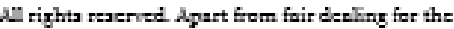
purpeses of study, racerch eritieism, or review, en permitted under the applitrble eopyright legialation, so gert of this vork mer be reprodueed by eny proees vithout written permixion ferm the pabliaher. For perminions and other intruiria, please centact

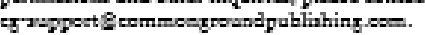

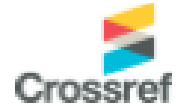

Commos Ground Rublihing is a member of Cresuref. 


\title{
Heat and Human Comfort in a Town in Brazil's Semi-arid Region
}

\author{
Rebecca Luna Lucena, Universidade de Brasilia, Brasil \\ Tacio Henrique de Freitas Santos, Universidade Federal do Rio Grande do Norte, Brasil \\ Almir Miranda Ferreira, Universidade Federal do Rio Grande do Norte, Brasil \\ Ercilia Torres Steinke, Universidade de Brasilia, Brasil
}

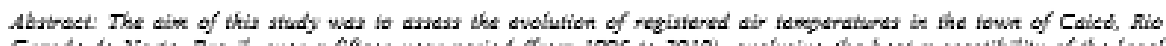

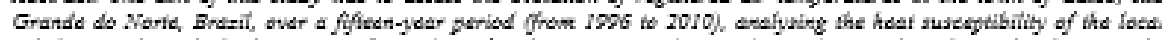

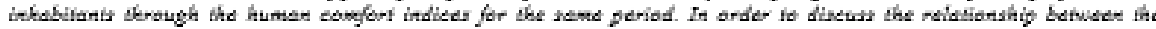

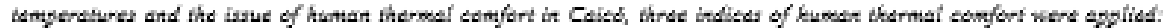

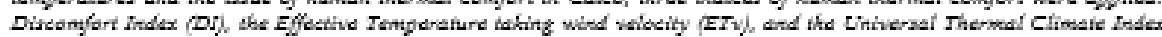

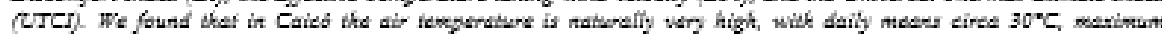

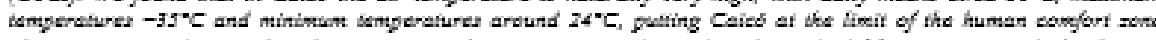

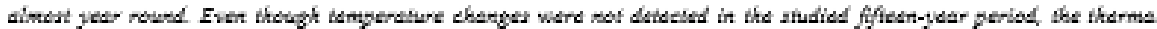

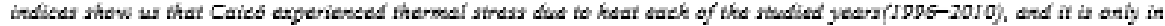

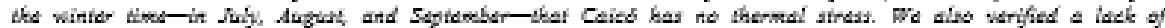

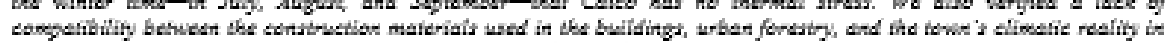

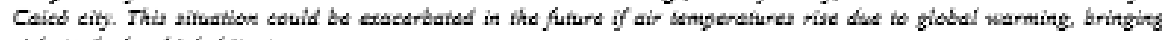
riskes to the losed ivkebilants.
\end{abstract}

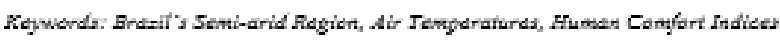

\section{Introduction}

\begin{abstract}
A ccording to the future climate scenario projections published by the Intergovernmental Panel on Climate Change, global temperatures could rise $4.8^{\circ} \mathrm{C}$ by 2100 (IPCC 2013). The prognosis for Brazil's semi-arid region is that there will be a $3^{\circ} \mathrm{C}$ increase in summer temperatures in the same period (Marengo et al. 2011). Projections of these kinds must be appraised very carefully in places that are naturally hot, such as the area between the tropics. Another process that is just as important as climate change and global warming is globalization, which has produced and continues to disgeminate architectural designs that are inappropriate for places where the temperature is naturally high, as is the case in much of Brazil, where poorly planned urban developments little suited to the local climate have triggered temperature increases as soil and vegetation have been replaced by construction materials that store more thermal energy (Oke 1996; Monteiro and Mendonça 2003; Bittencourt 2010)

In an increasingly urbanized world, trangformations have been seen in land uses in many places, altering the balance of local radiation and tending to raise temperatures, causing the phenomenon known as "heat islands" inside urban agglomerations. According to Taha (1997), these have been recogniged and documented since the early twentieth century, on different scales, and have different effects depending on the various interactions between the local climatic conditions, thermo physical conditions, and geometric configurations of the built-up areas. He adds that in low latitude regions, heat islands are not normally welcome because they can exacerbate thermal discomfort (Monteiro and Mendonça 2003).

Not only are the building materials used and the forms of the buildings often completely inappropriate for the climate, but the urban development projects often fail to take the local topography and urban forestry into account (Barbirato 2010). Many Brazilian towns and cities, like our current study site, have few street trees while those that they have are overpruned,
\end{abstract}

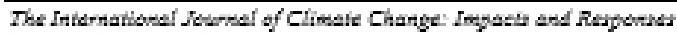

Volume 8, Isve 4, 2016, wow. co-climste com

- Common Ground Publishing, Rebecca Luna Lecens, Tacio Henrigue de Freitas Samtos,

Almir Miranda Fecreira, Ereiliz Torros Steinke, All Rights Resarved

Permissions: cg-supporth oommongroundpablishing com

ISSN: 1835-7156 (Print) 
heightening thermal discomfort in certain parts of these urban areas. Human thermal discomfort takes place when "phygiological reactions to thermal stress include changes to the metaboligm, dilation and contraction of blood vessels, faster or slower heart rate, sweating, and others" (Santos and Melo 2011, 154). The use of low-albedo materials and the lack of trees are factors that are strongly implicated in increasing the discomfort and even affecting the health of people living in these places (Sette and Ribeiro 2011).

In view of these circumstances, the main objective of this study was to analyse the behaviour of temperatures in the municipality of Caico in the state of Rio Grande do Norte (in Brazil's semi-arid region) analysing the heat susceptibility of the local inhabitants through human comfort indices scientifically recognized. The human thermal comfort indices-despite being climatic classifications with gubjective characteristics involving questions linked with human perception-is used by several meteorological services around the world and can be easily measured by users to describe the potential heat condition and thermo-regulation processes by which people are subjected (Winslow, Herrington, and Gagge 1937; Blazejczyc 2012). These indices are very important to climatic, health, urbanistics, and architecture studies; however, they are complex due to the implicit subjectivity. These indices represent, in a single parameter, the combined effect of two or more climatic variables (ASHRAE 2009).

According to Blazejczyc $(2012,515)$ : "Throughout the last century there has been much active research on how to define thermal comfort and how to grade thermal stress. These efforts have resulted in various models attempting to describe thermal comfort and the resultant thermal stress. A large number of indices have been proposed, which are (or were) in use throughout the world [about 40 indices were listed by Epstein and Moran (2006) and there are many others]."

In this work, we chose the most user-friendly indices, that consider only meteorological variables, such as the Discomfort Index (DI), Effective Temperature with wind (ETv), and Universal Thermal Climate Index (UTCT). They were used by many scientists in the area, DI by Matzarakis and Mayer (1991), Moran and Epstein (2006), Yousif and Tahir (2013), Ongoma and Muthama (2014), Polydoros and Cartalis (2015); ETv by Suping et al. (1992), Makokha (1998), Nedel et al. (2006), Blazejczyk (2012); and UTCI, studied more recently by Jendritzky et al. (2012), Abdel-Ghany et al. (2013), and Bröde et al. (2014).

In an increasingly urbanized world, the human comfort climate indexes should be used more often and improved to infer the thermal situation of cities with respect to human comfort and quality of life of the population.

\section{Location of the Study Area}

The municipality of Caico is in the northeast of Brazil (Figure 1.a) in a low-latitude zone ( $6^{\circ} 27^{\prime}$ $30^{\prime \prime}$ south and $37^{\circ} 05^{\prime} 52^{\prime \prime}$ weat). The mean altitude is 161 meters, giving it very peculiar characteristics such as high radiation rates and high temperatures all year round. It covers 1,229 $\mathrm{km}^{2}$ (BRASIL 2013a) and is the most important municipality in the Serido region because of the relative strength of its commerce, livestock farming, large-scale festivities, number of educational establishments, etc. It has an estimated population of 63,000 (BRASIL 2013 b). Caicó has a better human development index (HDI) - 0.750 - than other municipalities in the semi-arid region, where the average $\mathrm{HDI}$ is around 0.650 (Santana 2007). 


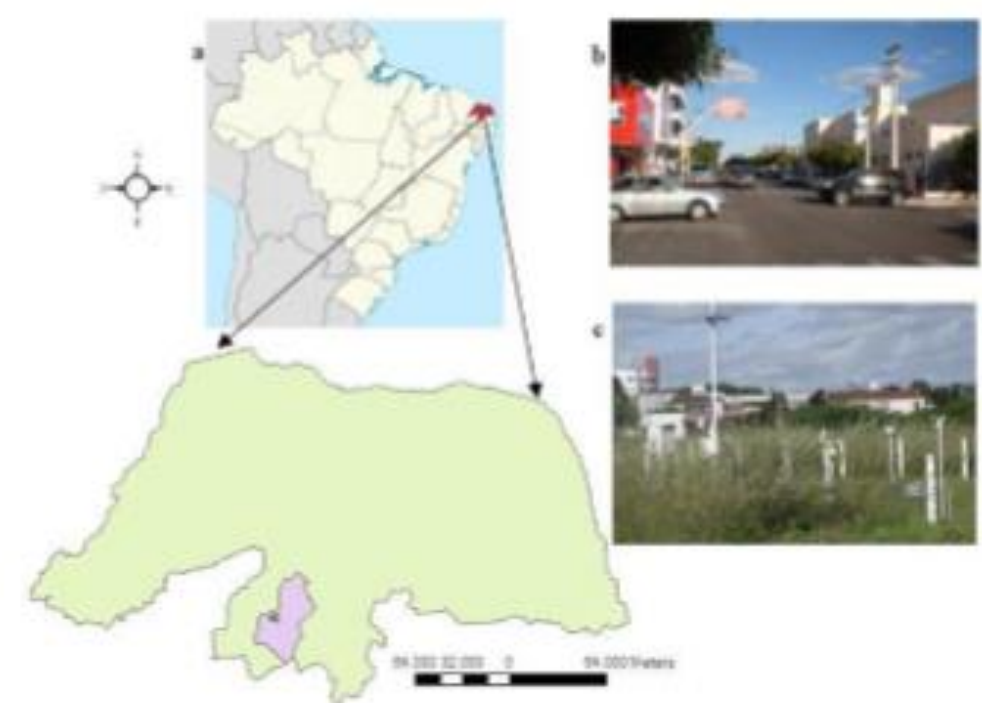

Figure 1: a) Myp Showing the Location of Crico in Braxil, the Borders of the State of Rio Gramde do Norts, the Municipslity and the Urbun Arsa; b) Cotonel Mrtimimo Averos; c) Serids Wouther Station

Soured: Resdarek Date

\section{Methodology}

In order to discuss the relationship between the temperatures and the issue of human thermal comfort in Caico, field studies were done that involved taking photographic records and applying three scientifically recognized indices of human thermal comfort: Discomfort Index (DI), Effective Temperature taking wind velocity (ETv), and Universal Thermal Climate Index (UTCI). To analyse the temperatures in Caico, and how these affect the comfort of the local people, the following methodological procedures were adopted.

First, the meteorological variables to be analysed were selected: air temperature, relative humidity of the air, and wind speed. This information was gathered from the database run by the Brazilian meteorological institute (Instituto Nacional de Meteorologia do Brasil) (INMET 2009; 2012) and the Serido weather station in Caicó, also managed by INMET. A fifteen-year time series was used (1996-2010) since the Seridó weather station only has complete data as of 1996.

Having gathered the data, an analysis of annual (month by month) and interannual variations in the maximum and minimum air temperatures was begun by preparing the climate normals. As such, the averages calculated were "provisional normal," which, according to the WMO, can be based on observations over a period of at least ten years (WMO 1989, cited in Oliveira and Vecchia 2010).

Having obtained the maximum and minimum air temperatures, we calculated the mean (x), standard deviation (S), coefficient of variation (CV), and trend uaing the angular coefficient of the estimated regression line. The trend lines were prepared using the estimated equation (Formula 1):

$$
\hat{Y}=b_{0}+b_{1} X_{i}
$$

where $\hat{Y}_{\text {is }}$ the estimated temperature dependent variable, $b_{0}$ is the estimated linear coefficient of the line, $b_{1}$ is the estimated angular coefficient of the line, and $\mathrm{X}_{1}$ is year " $\mathrm{i}$, " where " $\mathrm{i}$ " varies from 1996 to 2010 (time period over which temperatures were studied). Linear regression is a 


\section{THE INTERNATIONAL JOURNAL OF CLIMATE CHANGE: IMPACTS AND RESPONSES}

statistical method that identifies trends in data and analyses forecasting problems. It is widely used in climate research, such as Gonga et al. (2004), Ren Zhou (2011), and White-Newsome et al (2012). Using the formulas, tables and graphs were prepared to identify the annual and interannual temperature variations in the municipality of Caicó, Rio Grande do Norte, Brazil, with the software Microsoft Excel 10.0 for data analyges.

In order to assess human thermal comfort in the Caico climate, we chose three indices that have been used in a several works around the world with satisfactory results and published in national and international journals: Heat Stress, or Discomfort Index (DI, Formula 2), Effective Temperature taking wind velocity (ETv, Formula 3), and Univergal Thermal Climate Index (UTCI), which was calculated directly by the gite "UTCI calculation" (Wojtach 2014).

For the DI and TEv, we used the following equations:

$$
\mathrm{DI}=\mathrm{T}-0.55(1-0.01 \mathrm{RH})(\mathrm{T}-14.5) \text { (formula 2), (Matzarakis and Mayer 1991) }
$$

Where DI is the discomfort index in $\left({ }^{\circ} \mathrm{C}\right), \mathrm{T}$ is the dry bulb temperature $\left({ }^{\circ} \mathrm{C}\right)$, and $\mathrm{RH}$ is relative humidity (\%). This gives the thermal discomfort index (DI), which is classified into the following categories.

\begin{tabular}{c|c}
\multicolumn{2}{c}{ Table 1: Categories of Thermal Discomfort Index } \\
\hline $\mathrm{DI}\left({ }^{\circ} \mathrm{C}\right)$ & Level of Thermal Discomfort \\
\hline $\mathrm{DI}<21.0$ & no discomfort \\
\hline $21.0 \leq \mathrm{DI}<24.0$ & under $50 \%$ of the population feels discomfort \\
\hline $24.0 \leq \mathrm{DI}<27.0$ & around $50 \%$ of the population feels discomfort \\
\hline $27.0 \leq \mathrm{DI}<29.0$ & most of population feels discomfort \\
\hline $29.0 \leq \mathrm{DI}<32.0$ & everyone feels severe heat stress \\
\hline $\mathrm{DI} \geq 32.0$ & state of medical emergency \\
\hline
\end{tabular}

$\mathrm{ETv}=37-(37-\mathrm{T})[0.68-0.0014 \mathrm{RH}+1 /(1.76+1.4 \times 0.75)]-0.29 \mathrm{~T}(1-\mathrm{RH} / 100)$ (formula 3), (Suping et al 1992)

Where ETv is effective temperature as a function of wind speed, air temperature, and relative humidity, $\mathrm{T}$ is dry bulb temperature $\left({ }^{\circ} \mathrm{C}\right) ; \mathrm{RH}$ is relative humidity (\%); and $\mathrm{v}$ is wind speed $(\mathrm{m} / \mathrm{s})$ (Suping et al. 1992).

The ETv values were divided into the following categories. 
LUCENA ET AL.: HEAT AND HUMAN COMFORT IN A TOWN IN BRAZIL'S SEMII-ARID REGION

\begin{tabular}{c|c|c} 
& \multicolumn{3}{c}{ Table 2: Categories of ETv Values } \\
\hline ET $\left({ }^{\circ} \mathrm{C}\right)$ & Thermal Sensation & Degree of Physiological Stress \\
\hline $\mathrm{ET}<5$ & very cold & extreme cold stres5 \\
\hline $5 \leq \mathrm{ET}<10$ & Cold & extreme cold stres5 \\
\hline $10 \leq \mathrm{ET}<13$ & moderately cold & Shivering \\
\hline $13 \leq \mathrm{ET}<16$ & quite cool & cooling of the body \\
\hline $16 \leq \mathrm{ET}<19$ & slightly cool & slight cooling of the body \\
\hline $19 \leq \mathrm{ET}<22$ & Mild & contraction of blood vesgels \\
\hline $22 \leq \mathrm{ET}<25$ & Comfortable & thermal neutrality \\
\hline $25 \leq \mathrm{ET}<28$ & Warm & slight sweating, dilation of \\
& blood vesgels \\
\hline $28 \leq \mathrm{ET}<31$ & quite hot & Sweating \\
\hline $31 \leq \mathrm{ET}<34$ & Hot & profuse sweating \\
\hline $\mathrm{ET}>34$ & very hot & thermoregulatory failure \\
\hline
\end{tabular}

By using Wotjach's (2014) UTCI Calculator, we have the following result of the equivalent temperature:

Table 3: UTCI Equivalent Temperature

\begin{tabular}{c|c}
\hline UTCI $\left({ }^{\circ} \mathbf{C}\right)$ & Level of Thermal Comfort \\
\hline $0-10$ & Slight cold stress \\
\hline $10 \leq$ UTCI $<26$ & No thermal stress \\
\hline $26 \leq$ UTCI $<32$ & Moderate heat stress \\
\hline $22 \leq$ UTCI $<38$ & Strong heat stress \\
\hline \multicolumn{2}{c}{ Sourse: Brose of al. 2014 }
\end{tabular}

The human comfort indices were calculated in an annual and monthly period from 1996 until 2010 , where we analysed the annual and monthly mean for each index.

\section{Results And Discussion}

\section{Temperature Analysis (1996-2010)}

The northeast of Brazil has high temperatures almost all year round, with a few exceptions where the elevation is higher (Ab'gaber 2003). Caico is in the north of Brazil's northeast region (Figure 1). The altitude is low, it is about $200 \mathrm{~km}$ from the gea, and it has some of the highest temperatures in Brazil, which already has a predominantly hot climate, except in the south and goutheast. The time geries analysis from 1996 to 2010 showed that in the municipality of Caico, temperatures are naturally very high in almost every month of the year (Table 4, Figure 2), with an average temperature of $\sim 30^{\circ} \mathrm{C}$, an average maximum temperature of $\sim 35^{\circ} \mathrm{C}$, and an average minimum temperature of $\sim 24^{\circ} \mathrm{C}$. 
THE INTERNATIONAL JOURNAL OF CLIMATE CHANGE: IMPACTS AND RESPONSES

Table 4: Mean, Standard Deviation, and Coefficient of Variation of the Maximum and Minimum

\begin{tabular}{|c|c|c|c|c|c|}
\hline Caicó/RN & month/year & Mean_Max & StandDev & CoefVar & $\begin{array}{l}\text { CoefVar } \\
(90)\end{array}$ \\
\hline Max_Temp & Jan & 36,02 & 1,294 & 0,036 & 496 \\
\hline Max_Temp & $\mathrm{Feb}$ & 36,02 & 1,294 & 0,036 & $4 \%$ \\
\hline Max_Temp & Mar & 35,49 & 1,365 & 0,038 & $4 \%$ \\
\hline Max_Temp & Apr & 34,56 & 1,306 & 0,038 & $4 \%$ \\
\hline Max_Temp & May & 33,96 & 1,482 & 0,044 & $4 \%$ \\
\hline Max_Temp & Jun & 33,54 & 1,319 & 0,039 & $4 \%$ \\
\hline Max_Temp & Jul & 32,89 & 1,329 & 0,040 & $4 \%$ \\
\hline Max_Temp & Aug & 32,97 & 0,605 & 0,018 & $2 \%$ \\
\hline Max_Temp & Sep & 33,78 & 0,539 & 0,016 & $2 \%$ \\
\hline Max_Temp & Oct & 35,49 & 0,643 & 0,018 & $2 \%$ \\
\hline Max_Temp & Nov & 36,86 & 0,789 & 0,021 & $2 \%$ \\
\hline Max_Temp & Dec & 37,23 & 0,353 & 0,009 & $1 \%$ \\
\hline Max_Temp & Year & 34,90 & 1,026 & 0,030 & $3 \%$ \\
\hline Caicó/RN & month/year & Mean_Min & StandDev & CoefVar & $\begin{array}{c}\text { CoefVar } \\
(\%)\end{array}$ \\
\hline Min_Temp & $\operatorname{Jan}$ & 25,73 & 2,333 & 0,091 & $9 \%$ \\
\hline Min_Temp & $\mathrm{Feb}$ & 25,49 & 2,199 & 0,086 & $9 \%$ \\
\hline Min Temp & Mar & 24,86 & 1,836 & 0,074 & $7 \%$ \\
\hline Min_Temp & Apr & 24,27 & 1,321 & 0,054 & $5 \%$ \\
\hline Min_Temp & May & 23,83 & 1,246 & 0,052 & $5 \%$ \\
\hline Min_Temp & Jun & 23,37 & 1,519 & 0,065 & $6 \%$ \\
\hline Min_Temp & Jul & 22,93 & 1,730 & 0,075 & $8 \%$ \\
\hline Min_Temp & Aug & 23,33 & 2.248 & 0,096 & $10 \%$ \\
\hline Min_Temp & Sep & 24,27 & 2,319 & 0,096 & $10 \%$ \\
\hline Min_Temp & Oct & 24,83 & 2,373 & 0,096 & $10 \%$ \\
\hline Min_Temp & Nov & 25,89 & 2,395 & 0,093 & $9 \%$ \\
\hline Min_Temp & $\mathrm{Dec}$ & 26,33 & 2,556 & 0,097 & $10 \%$ \\
\hline Min_Temp & Year & 24,59 & 2,006 & 0,081 & $8 \%$ \\
\hline
\end{tabular}




\section{LUCENA ET AL.: HEAT AND HUMAN COMFORT IN A TOWN IN BRAZIL'S SEMI-ARID REGION}

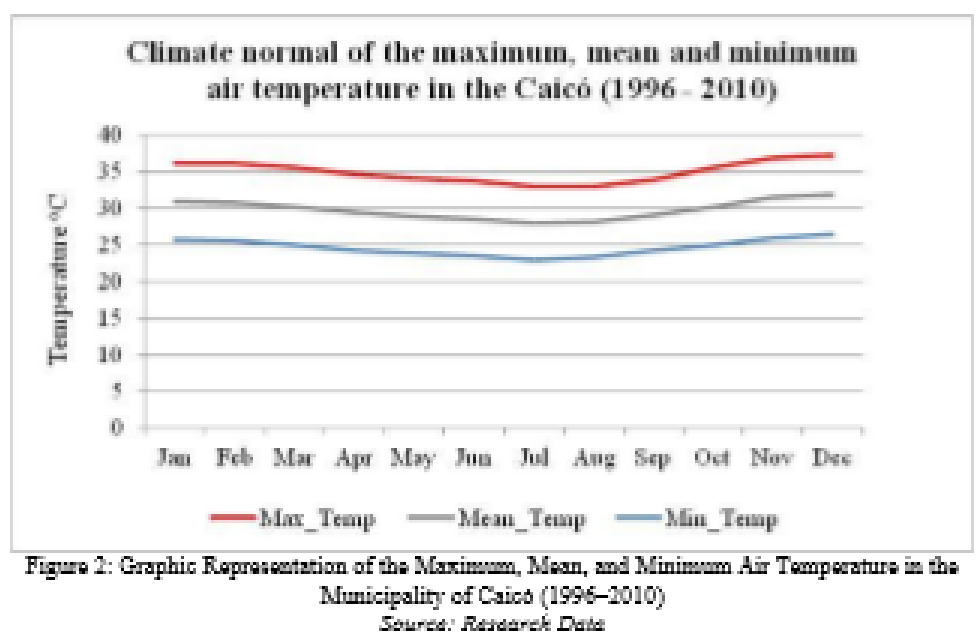

In Caico, annual temperature differences are very subtle, and it does not really have a cold season; as Ayoade (2007) explains, there is no winter in this part of the globe. The highest temperatures are between November and March, which is part of the dry season and when the mean temperatures the highest. The lowest temperatures are between June and September, when it is winter in the southern hemisphere. This pattem applies to the maximum, mean, and minimum temperatures. Another finding was that the maximum and minimum temperatures did not vary much over the period studied, although the minimum temperature did oscillate more. These data can be seen using the coefficient of variation (Table 4).

No upward or downward trend was identified in the interannual temperature variation. Despite the IPCC's statement that average temperatures could rise by $3^{\circ} \mathrm{C}$ this century in Brazil's semi-arid and northeastern regions, the temperature data are flat, and the angular coefficient of the regression line is statistically zero, showing that the maximum and minimum temperatures have remained practically constant, although there is more oscillation in the minimum temperatures (Figures 3 and 4).

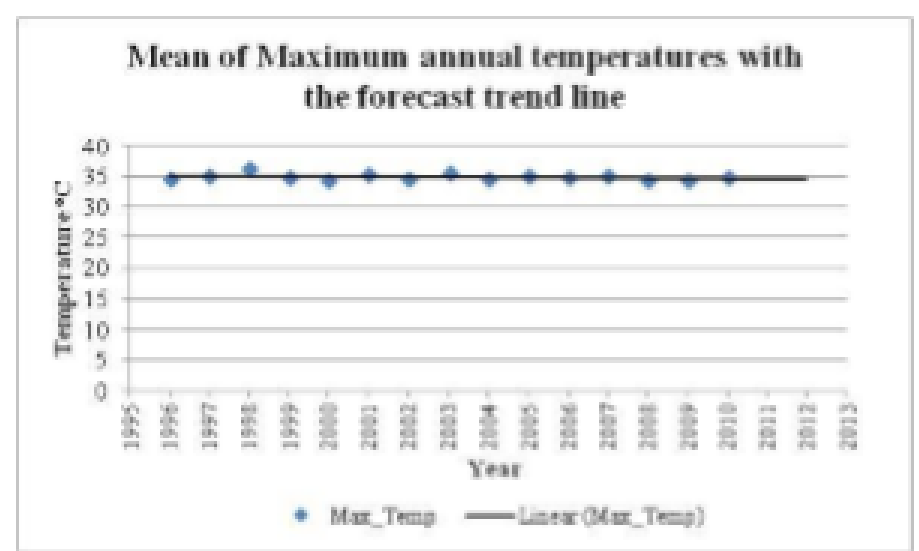

Figure 3: Maximum Anmual Temparatures for the Mumicipality of Caieo (1996-2010) with the Forecast Trond Line Sourte: Resderek Dalde 


\section{THE INTERNATIONAL JOURNAL OF CLIMATE CHANGE: IMPACTS AND RESPONSES}

The minimum temperatures oscillated more than the maximum temperatures in the interannual comparison. This can be seen in Figures 3 and 4 and Table 4, where the coefficient of variation was $3 \%$ for the maximum temperatures, but $8 \%$ for the minimum temperatures. The regression analysis yielded an estimated straight line almost parallel to the horizontal axis, which was not statistically gignificant, as was the case of the maximum temperature line (Figures 3 and 4). The lowest annual minimum temperatures (below $25^{\circ} \mathrm{C}$ ) were recorded in $1999,2000,2002$, and 2010 .

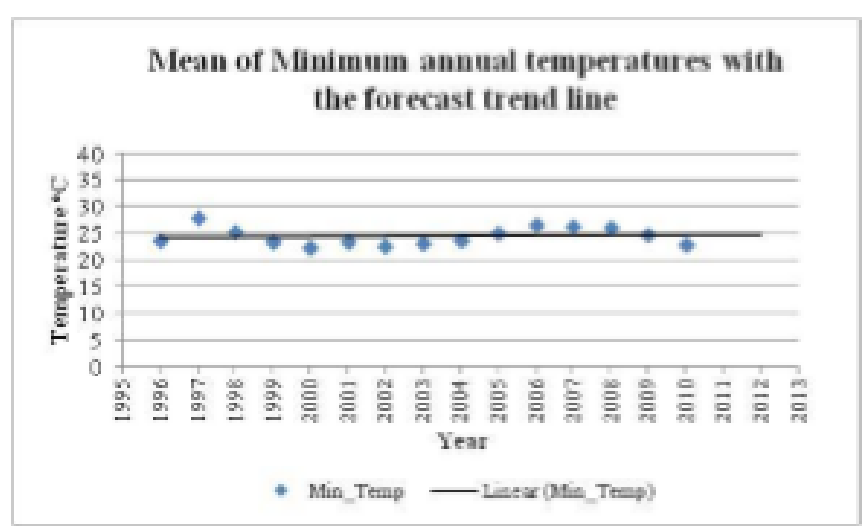

Figure 4: Graph of the Minimum Annul Temperature for the Memiciplity of Cuied (1996-2010) with the Foracast Trend Line

\section{Temperatures and Humen Themal Comfort}

Based on the climate data for Caicó used to calculate the provisional normals for the fifteen-year period from 1996 to 2010 , three thermal comfort indices were calculated-DI, ETv, and UTCI. The results of the annual mean temperature for the period in queation were as follows: a DI according to which "most of the population suffers discomfort," an ETv that is a "warm climate, inducing sweating and the dilation of blood vessels," and a UTCI that "moderate heat stres5." Table 5 shows the qualitative and quantitative results for Caicó city.

Table 5: The Annual Mean to Human Comfort Indices DI, Etv, and UTCI in Caicó, Based on the Time Series for 1996-2010 in Caicó, Brazil.

\begin{tabular}{|l|l|}
\hline Human Thermal Comfort Indices & $\begin{array}{l}\text { Caicó } \\
(1996-2010)\end{array}$ \\
\hline $\begin{array}{l}\text { DI } \\
\text { Discomfort Index }\end{array}$ & $\begin{array}{l}28.44-\text { most of the population } \\
\text { feels discomfort }\end{array}$ \\
\hline $\begin{array}{l}\text { ETv } \\
\text { Effective Temperature }\end{array}$ & $\begin{array}{l}27.13-\text { warm, sweating, dilation } \\
\text { of blood vessels }\end{array}$ \\
\hline $\begin{array}{l}\text { UTCI } \\
\text { Univergal Thermal Climate Index }\end{array}$ & $28.05-$ Moderate heat stress \\
\hline
\end{tabular}

The human thermal comfort indices were also applied for each month of the year for the period in question, and the monthly mean showed that, annually, in Caicó months with thermal stress due to the heat prevail. Figures 5,6, and 7 depicts graphics of the average behaviour for each month of the year according to DI, TEv, and UTCI. 


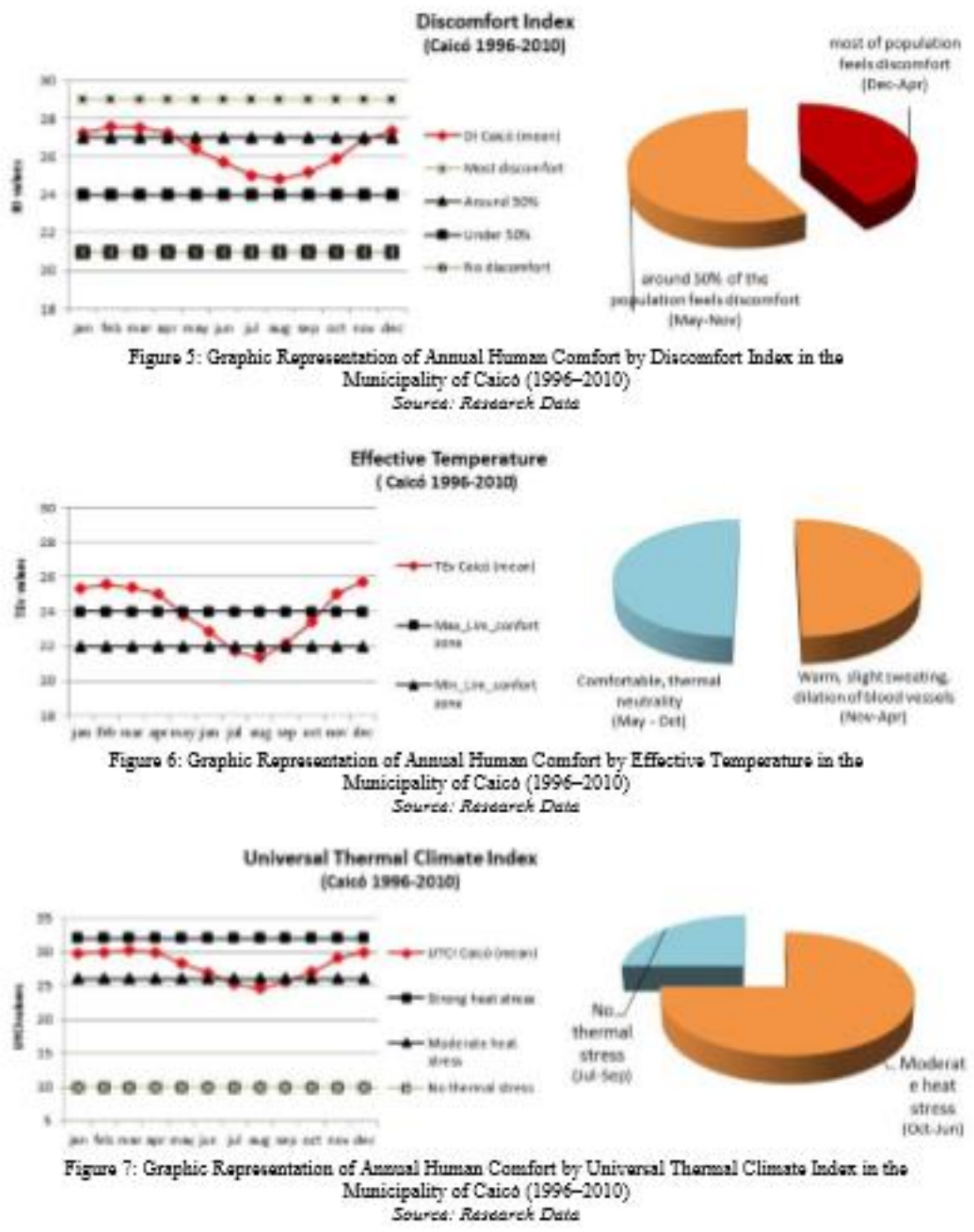

According to the applied indices, the results for the DI showed that Caico presents discomfort due to the heat in every month of the year. For TEv, the months of June, July, Auguat, September, and October appear within the thermal comfort, especially August that presents as "glightly cold." According to UTCI, the months of July, August, and September are included in the human comfort zone on the limit between the "comfort zone" and "moderate diacomfort due to heat"

The results show that only DI put Caico off the human comfort zone during every month of the year. However, we must emphasize that this index, although widely used, does not include 
the "wind speed," one great important variable in facilitating human comfort, gince wind velocity is as important as temperature and humidity in determining thermal exchanges between the body and the environment.

Studies by Santos (2011) and Santos et al. (2012) showed that the opinion of the people regarding the comfort ranges of the DI were not satisfactory when applied in a warm and humid place. This probably occurred due to the absence of the "wind" variable that relieves thermal sengation provided by the high temperatures and humidity in these places. Thus, detecting the incompatibility between the results obtained through a questionnaire applied to the population and those proposed by Giles and Balafoutis (1990), the authors proposed an adjustment and adaptation in the DI index in their study.

The indexes used in this paper that include "wind" showed in some months a favorable condition for human comfort. This occurs in the winter season in Southern hemisphere, mainly due the temperature drop and the increasing of wind speed by rising of southeast trade winds. Therefore, both the TEv as UTCI indicated a comfort situation for a few months of winter in Caico, unlike the DI that did not present climatic comfort in any time of the year.

\section{Climate, Urban Practices, and Human Comfort: Some Considerations}

In towns and cities where the climate is naturally hot, the poor adaptation of the architecture of the buildings, the limited number of street trees, and the overpruning of existing trees only tend to heighten thermal digcomfort. Different studies have shown that urban forestry not only has a positive impact on the landscape, but also helps reduce the temperature by covering surfaces that reflect the heat and by retaining part of the dust in the air (Grey and Deneke 1978; Junior and Lima 2007; and Ferreira et al. 2012).

According to Barbirato $(2010,86)$, "Plants reduce the air and soil temperature by ghading and evapotranspiration, increasing local humidity. . . likewise, large paved areas can cause discomfort because of the high absorption of radiation near the soil."

In Caico, the built-up area has paved roads and pavements as well as buildings made of bricks and cement. The façades of the buildings are made of glass, and the more high-end the establishment, the more glass is used. Urban forestry in the built-up area is hampered because of the overhead electricity cables: gmall and medium-sized species have been planted that do not provide a great deal of shade, and they are often cut back drastically. Figure $6(a, b, c, d, e$, and $f$ ) shows the glass fronts of the buildings on the town's main streets and some of the many cases of severe pruning in 2014 . 


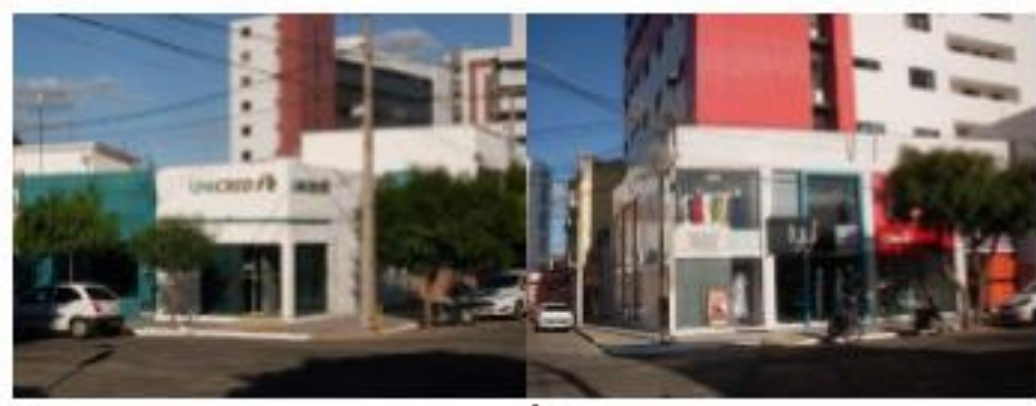

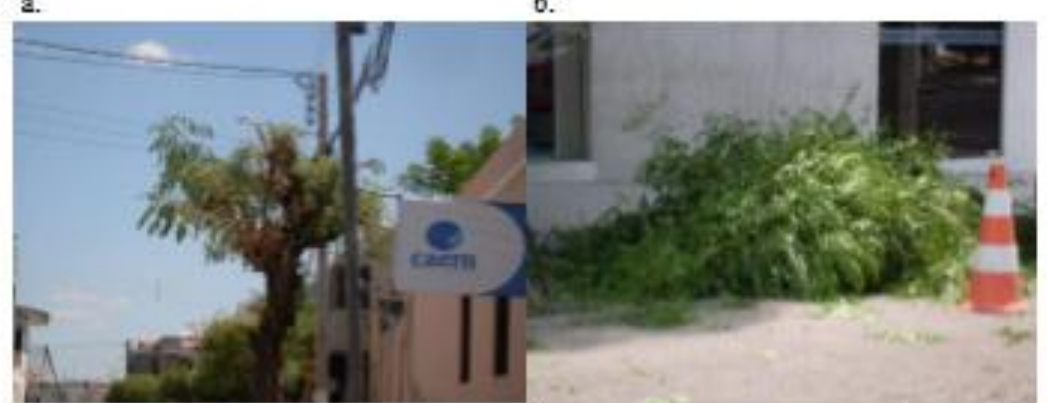

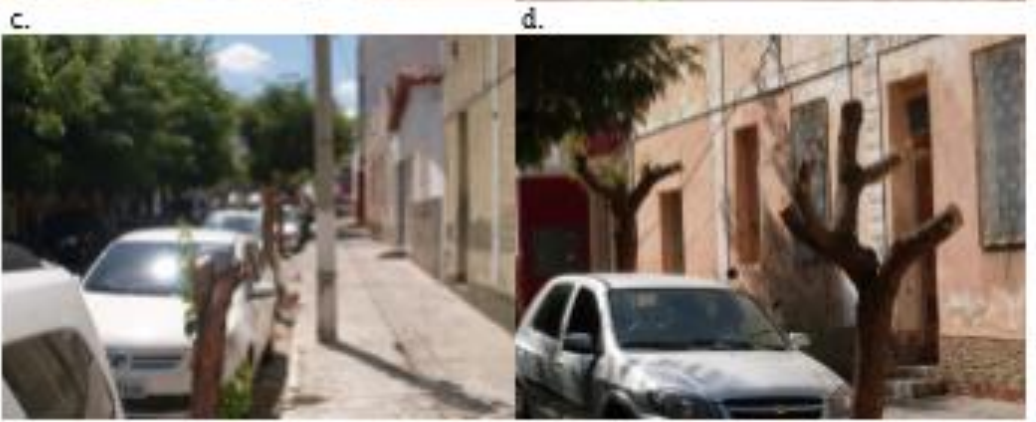

e.

Figure 6: ( $2, b, c, d$, e and A) Glass Fronts of the Brildings con the Main Streets of Caics, and Some of the Soveraly Pruned Treas in 2014

Solures: Residerek Dale

Glass, synonymous with luxury in Brazilian architecture, is very inappropriate for touns with a hot semi-arid climate like Caico. Even so, glass is often used on shop fronts, and is often protected by awnings at the hottest times of day. As glass promotes the greenhouse effect, more has to be spent on air conditioning to keep these spaces cool. This in turn increases the consumption of electricity by commercial establishments and homes.

In hot, dry climates, shading must be a priority in urban planning for both streets and buildings in the same way that daytime and nighttime wind control can increase human comfort without the need to resort to artificial cooling (Romero 2013). Planned tree planting using species that cast more shade is also a way to keep temperatures down, controlling the micro-climate according to local climatic conditions. Towns and cities that grow in line with the globalized paradigms of urban development tend to expose their residents to thermal discomfort because 
their architecture and landscape design is not adapted to the climate. And in towns naturally hot, like Caicó, it will be very dangerous for the future of the local population.

\section{Concluding Remarks}

In this study, it was found that in the municipality of Caico, the air temperature is naturally very high, with an average temperature of $\sim 30^{\circ} \mathrm{C}$, an average maximum temperature of $\sim 35^{\circ} \mathrm{C}$, and an average minimum temperature of $\sim 24^{\circ} \mathrm{C}$. Most of the year, it is at the limit of human comfort because of the excessive heat, as was confirmed by calculating the human comfort indices DI, ETv and UTCI. However, the regression analysis for 1996 to 2010 ghowed that the maximum and minimum air temperatures showed no upward or downward trend, since the trend line ran parallel to the horizontal axis and showed no statistically gignificant variations. The minimum temperatures oscillated more than the maximum temperatures in the interannual comparison, where the coefficient of variation was $3 \%$ for the maximum temperatures, but $8 \%$ for the minimum temperatures.

Even though the air temperature time series was flat, the analysis of human comfort indices showed that in Caico, only in the winter season-mainly during the months of July, August, and September-the conditions are favorable to human thermal comfort, showing that in the remaining months the city is outside of the comfort zone due to heat. Using the DI index, Caico does not have any month inside the comfort level, appearing outside of the comfort zone due to heat throughout the year. ETv revealed that May, June, July, August, September, and October are inside of the human comfort zone, emphasizing August as being categorized as "slightly cool" The UTCI index showed that Caico has three months that can be considered comfortable: June, July, and August.

The DI index exposed the most rigorous answers about climate comfort conditions for the city, since this index does not have the wind speed variable in its formula, and it is a very important variable to analyze the human comfort. So, we guggest, for warmer and hotter places the utilization of indexes that use the wind speed variable.

Finally, it was observed that the design of the buildings was inappropriate, with many using concrete and glass, while the absence of trees in the town and the severe pruning of those trees that it has tends to heighten the thermal discomfort in Caicó. As such, any increase in the air temperature brought about either by global climate change or even by changes in local land uses could have a major negative impact on the residents who already experience daily atmospheric conditions that cause discomfort because of the excessive heat.

\section{Acknowledgement}

To Brazilian Meteorological Institute (INMET-Instituto Nacional de Meteorologia) for the meteorological data used in this study. 


\section{LUCENA ET AL.: HEAT AND HUMAN COMFORT IN A TOWN IN BRAZIL'S SEMI-ARID REGION}

\section{REFERENCES}

Ab'saber, Aziz Nacib. 2003. "Caatingas: o dominio dos gertões secos." ["Caatingas: The Field of Dry Lands."] In Os domínios de natureza no Brasil: Potencialidades paisagísticas. [The Domains of Nature in Brazil: Potential Landscapes], edited by Aziz Nacib Ab'saber, 83-100. São Paulo: Ateliê Editorial.

Abdel-Grany, A. M, I. M Al-Helal, and M. R. Shady. 2013. "Human Thermal Comfort and Heat Stress in an Outdoor Urban Arid Environment: A Case Study." Adwances in Meteorology. doi:10.1155/2013/693541.

American Society of Heating, Refrigerating and Air Conditioning Engineers (ASHRAE). 2009. "Chapter 9: Thermal Comfort." In Handbook Fundamentals, edited by Mark S. Owen, 9.1-9.27. Atlanta: ASHR.AE H.ANDBOOK.

Ayoade, John Olaniyi. 2007. Introdução à Climatologia para os Trópicos. [Introduction to Climatology for the Tropics]. Translated by Maria Juraci Zani dos Santos. Rio de Janeiro: Bertrand Brasil.

Barbirato, Gianna Melo. 2010. "A importância da abordagem climática no planejamento urbano." ["The Importance of Climatic Viewpoint in Urban Planning."] In Atmosfera e sociedade: a ação da atmosfera sobre os seres vivos e a qualidade de vida humana. [Atmosphere and Society: The Action of the Atmosphere on Living Beings and Human Life Quality], edited by Jose Clênio Ferreira de Oliveira, 75-90. Maceió: EDUFAL.

Bittencourt, Leonardo Salazar. 2010. "O clima como formador do repertório arquitetônico." ["The Weather as Shaper of the Architectural Repertoire."] In Atmosfera e sociedade: a ação da atmosfera sobre os seres vivos e a qualidade de vida humana. [Atmosphere and Society: The Action of the Atmosphere on Living Beings and Human Life Quality], edited by José Clênio Ferreira de Oliveira, 103-22. Maceió: EDUFAL.

Blazejczyk, Krzysztof, Yoram Epstein, Gerd Jendritzky, Henning Staiger, and Birger Tinz. 2012. "Comparison of UTCI to Selected Thermal Indices." International Joumal of Biometeorology 56: 515-35. doi:10.1007/900484-011-0453-2.

BRASIL. 2013a. "Instituto Brasileiro de Geografia e Estatística. IBGE Estados." ["Brazilian Institute of Geography and Statistics. IBGE States."] Accessed October 20. www.ibge.gov.br/eatadosat/perfil.php?sigla=rn.

- 2013b. "Ministério do Desenvolvimento Agrário. Sistema de Informações Territoriais. Indices de Desenvolvimento do Serido - RN." ["Ministry of Agrarian Development. Territorial information system. Serido's Development Indexces- RN.'] Accessed May 10. http://sit mda.gov.br/territorio.php?ac=buscar\&base=1\&abr=uf\&regiao=\&uf $=\mathrm{RN} \&$ eterritorio $=76$ \& tema $=6$.

Bröde, Peter, Dusan Fiala, Krzygztof Blazejczyk, Yoram Epstein, Ingvar Holmés, Gerd Jendritzky, Bernhard Kampmann, Mark Richards, Hannu Rintamaki, Avraham Shitzer, and George Havenith 2009. Calculating UTCI Equivalent Temperatures. Poster Presented at the $13^{\mathrm{th}}$ International Conference on Environmental Ergonomics, Boston, MA. Accessed November 2014. www.utci.org/utci_poster.pdf.

Epatein, Y, and D. S. Moran 2006. "Thermal Comfort and the Heat Stress Indices." Industrial Health 44 (3): 388-98. doi:10.2486 indhealth.44.388.

Ferreira, Cássia de C. Martins, Débora Couto de Assis, Franciele de Oliveira Pimentel, and Daiane Evangelista de Oliveira. 2012. "O estudo do microclima gerado por praças em relação aos geus arredores na cidade de Juiz de Fora-MG." ["The Study of the Microclimate Generated by Squares in Relation to Its Surroundings in the City of Juiz de Fora-MG-Brazil."'] Revista GeoNorte, Edição Especial 2 (5): 496-508.

Giles, B. D., and C. J. Balafoutis. 1990. "The Greek Heat Waves of 1987 and 1988." International Joumal of Climatology 10 (5): 505-17. 
Gonga, Dao-Yi, Pei-Jun Shia, and Jing-Ai Wangb. 2004. "Daily Precipitation Changes in the Semi-arid Region over Northern China." Joumal of Arid Environments 59: 771-84. doi:10.1016/j.jaridenv.2004.02.006.

Grey, Gene $W_{\text {, }}$ and Frederick J. Deneke. 1978. Urban Forestry. New York: John Wiley.

INMET. 2009. Normais climatológicas do Brasil 1961-1990 [Climatological Normals of Brasil 1961-1990], edited by Andrea Malheiros Ramos, Luiz André Rodrigues dos Santos, and Lauro Tadeu Guimarẩes Fortes. Brasilia, DF: INMET.

- 2012. "BDMET: Banco de dados Meteorológicos." ["BDMET: Meteorological Database."]. Accessed April 12. www.inmet.gov.br.

IPCC. 2013. "Climate Change 2013: The Physical Science Basis." Accessed May 27. www.climatechange2013.org.

Jendritzky, Gerd, Richard de Dear, and George Havenith. 2012. "UTCI-Why another Thermal Index? International Joumal of Biometeorology 56: 421-28. doi:10.1007/900484-011-0513-7.

Junior, Jogé H. de Aguirre, and Ana Maria L. Pereira Lima. 2007. "Ugo de árvores e arbustos em cidades brasileiras." ["The Uge of Trees and Shrubs in Brazilian Cities."] Revista SBAU Piracicaba 2 (4): 50-66.

Makokha, George Lukoye. 1998. "Variations of the Effective Temperature Index (ET) in Kenya." GeoJoumal 44 (4): 337-43. doi:10.1023/A:1006880509054.

Marengo, José A., Carlos A. Nobre, Sin Chan Chou, Javiar Tomasella, Gilvan Sampaio, Lincoln M. Alves, Guillermo O. Obregon, Wagner R. Soares, Richard Betts, and Gillian Kay. 2011. Riscos das mudanças climáticas no Brasil: análise conjwota Brasil - Reino Unido sobre os impactos das mudanças climáticas e do desmatamento na Amazbnia [Rishs of Climate Change in Brazil: Brazil-UK Joint Analysis about the Impacts of Climate Change and Deforestation in the Amaron]. Location of Publisher: INPE/Met Office.

Matzarakis, Andreas, and Helmut Mayer. 1991. "The Extreme Heat Wave in Athens in July 1987 from the Point of View of Human Biometeorology." Atmospheric Environment 25b (2): 203-11. doi:10.1016/0957-1272(91)90055-J.

Monteiro, Carlos Auguato de Figueiredo, and Francisco Mendonça. 2003. Clima Uirbano. [Urban Climate.] São Paulo: Contexto.

Nedel, Anderson S., Micheline de Sousa Coelho, and Fabio Luiz Teixeira Gonçalves. 2006. Comparative Analusis of Different Human Thermal Comfort Indexes in São Paulo Ciny and Their Relationship with Respiratory Morbidity. Proceedings of 8 ICSHMO, Foz do Iguaçui, Brazil, April 24-28, INPE, 675-77.

Oke, Tim R. 1996. Bownday Laver Climates. New York: Routledge.

Oliveira, Marcos José de, and Francisco Vecchia. 2010. "Elaboraçäo de normais climatológicas: Caracterização e tendências de temperatura em Itirapina - SP, Brasil" ["Preparation of Climatological Normals: Characterization and Temperature Trends in Itirapina-SP, Brazil.'] Paper presented at a meeting for the XVI Meteorological Brazilian Congress, Pará, Belém: September 13-17.

Ongoma, Victor, and John Nzioka Muthama. 2014. "A Review and Assessment of Applicability of the Heat Stress Indices in Kenyan Weather Forecast." Open Jowrnal of Atmospheric and Climate Change 1 (1): 17-22.

Polydoros, T., and C. Cartalis. 2015. "Assessing Thermal Riak in Urban Areas-An Application or the Urban Agglomeration of Athens." Accessed December 22, 2015. www.aivc.org/sites/default/files/198.1370023063fullpdf.

Romero, Marta Adriana Bustos. 2013. Princípios biocilmáticos para o desenho wrbano. [Bioclimatic Basis for Urban Design.] Brasilia: Editora Universidade de Brasilia.

Santana, Marcos Oliveira. 2007. Atlas das áreas susceptíveis à desertificaçâo do Brasil. [Brarilian Atlas of Surceptible Areas to Desertification]. Brasilia: MMA-Miniaterio do Meio Ambiente. 


\section{LUCENA ET AL.: HEAT AND HUMAN COMFORT IN A TOWN IN BRAZIL'S SEMI-ARID REGION}

Santos, J. S. dos. 2011. "Campo térmico urbano e a sua relaçäo com o uso e cobertura do solo em cidade de clima tropical úmido." ["Urban Thermal Field and Their Relationship with Soil Uge and Coverage in a City with Humid and Tropical Weather"]. Tese de Doutorado, Programa de Pós-graduação em Recursos Naturais, Universidade Federal de Campina Grande (UFCG).

Santos, J. S. dos, V. de P. R. da Silva, L. E. de Araujo, and A. D. L. Costa 2012. "Campo Térmico Urbano e a sua Relação com o Uso e Cobertura do Solo em Cidade Tropical Umida." ["Uroan Thermal Field and Their Relationahip with Soil Use and Cover in a Humid Tropical City."] Revista Brasileira de Geografia Física 3: 540-57.

Santo5, Wially Roger Tavares, and Maria Luciene Dias de Melo. 2011. "fndices de conforto e desconforto térmico humano segundo os cenários climáticos do IPCC." ["Thermal Comfort and Discomfort Human Indices of According to IPCC Climate Scenarios."] In Atmosfera e sociedade: aspectos muiti 6 interdisciplinares da meteorologia [Atmosphere and Society: Multi and Interdisciplinary Aspects of Meteorology], edited by José Clênio Ferreira de Oliveira, 153-63. Maceió: EDUFAL.

Sette, Ribeiro. 2011. "Interaçôes entre o clima, o tempo e a saúde humana." ["Interactions Between the Climate, Weather and Human Health."] Interfacehs: revista de saúde, meio ambiente o sustentabilidade [Interfacehs: Jownal of Health Environment And Sustainability] 6 (2): $37-50$.

Souza, Débora Moreira de, and Jonas Teixeira Nery. 2012. "O Conforto térmico na perspectiva da Climatologia Geográfica." ["The Thermal Comfort in the Geographic Climatology Context."] Geogrqfia (Londrina) 21 (2): 65-83.

Suping, Zhang, Meng Guanglin, Wang Yanwen, and Li Ji 1992. "Study of the Relationghips between Weather Conditions and the Marathon Race, and of Meteorotropic Effects on Distance Runners." International Journal of Biometeorology 36: 63-68. doi:10.1007/BF01208915.

Taha, Haider. 1997. "Urban Climates and Heat Islands: Albedo, Evapotranspiration, and Anthropogenic Heat." En6rgy and Buildings 25: 99-103. doi:10.1016/S0378-7788(96)00999-1.

White-Newsome, Jalonne L., Brisa N. Sánchez, Olivier Jolliet, Zhenzhen Zhang, Timothy J. Dvonch, and Marie S. O'neill. 2012. "Climate Change and Health: Indoor Heat Exposure in Vulnerable Populations." Environmental Research 112: 20-27. doi:10.1016 j.envres.2011.10.008.

Winslow, C. E. A., L. P. Herrington, and A. P. Gagge. 1937. "Physiological Reactions on the Human Body to Varying Environmental Temperatures." Jownal of Physiology 120: 288-99.

Wojtach, Barbara. 2014. "UTCI Calculator." Accessed April 03. www.utci.org/utcineu/utcineu.php.

Yousif, Tawhida A., and Higham M. M. Tahir. 2013. "Application of Thom's Thermal Discomfort Index in Khartoum State, Sudan." Jowrnal of Forest Products \& Industries 2 (5): 36-38.

Zhou, Yaqing, and Guoyu Ren. 2011. "Change in Extreme Temperature Event Frequency over Mainland China, 1961-2008." Climate Research 50: 125-39. doi:10.3354/cr01053. 
THE INTERNATIONAL JOURNAL OF CLIMATE CHANGE: IMIPACTS AND RESPONSES

\section{ABOUT THE AUTHORS}

Rebecca Luna Lucena: PhD Student, Departamento de Geografia, Universidade de Bragília UNB, Brasilia, Distrito Federal, Brazil

Tacio Henrique de Freitas Santos: Scholarship Student in Climatological Station, Departamento de Geografia da UFRN, Universidade Federal do Rio Grande do Norte, Caicó, Rio Grande do Norte, Brazil

Abmï Miranda Ferreira: Teacher, $\mathrm{PhD}$ student, Departamento de Estatistica da UFRN, Universidade Federal do Rio Grande do Norte, Caicó, Rio Grande do Norte, Brazil

Ercilia Torres Steinke: Teacher, Departamento de Geografia, Universidade de Brasilia - UNB, Brasilia, Distrito Federal, Brazil 
Universidade de Brasília

GEA - Departamento de Geografia PPG/GEA- Programa de Pós-Graduação

The International JoumaV of Cllmate Change:

Impacts and fiesponses seeks to create an

interdisciplinary form lor discussion of evidence of

climate changa, its causes, its eccsystemic impects

and its human impacts. The journal also explores

technological, policy, strategic, and social responses to

climals changs.

The internationer uloumer of OWmate Onenge: impects

end frasponses is a poor-rcalowod, scholarly loumsl. 